Report No. BMI-1375

UC-10 Chemistry - Separation Processes for Plutonium and Uranium (TID-4500, 14th Ed.)

Contract No. W-7405-eng-92

CONSTRUCTION MATERIALS FOR VARIOUS HEAD-END PROCESSES FOR THE AQUEOUS REPROCESSING OF SPENT FUEL ELEMENTS

by

Charles L. Peterson

Paul D. Miller

James D. Jackson

Frederick W. Fink

Sponsored by the Chemical Technology Division of the Oak Ridge

National Laboratory of the Atomic Energy Commission, operated by Union Carbide Nuclear Company

August 28, 1959

BATTELLE MEMORIAL INSTITUTE

505 King Avenue

Columbus 1, Ohio 


\section{DISCLAIMER}

This report was prepared as an account of work sponsored by an agency of the United States Government. Neither the United States Government nor any agency Thereof, nor any of their employees, makes any warranty, express or implied, or assumes any legal liability or responsibility for the accuracy, completeness, or usefulness of any information, apparatus, product, or process disclosed, or represents that its use would not infringe privately owned rights. Reference herein to any specific commercial product, process, or service by trade name, trademark, manufacturer, or otherwise does not necessarily constitute or imply its endorsement, recommendation, or favoring by the United States Government or any agency thereof. The views and opinions of authors expressed herein do not necessarily state or reflect those of the United States Government or any agency thereof. 


\section{DISCLAIMER}

Portions of this document may be illegible in electronic image products. Images are produced from the best available original document. 
ABSTRACT. . . . . . . . • . . . . . . . . . . . . . . 1

INTRODUCTION . . . . . . . . . . . . . . . . . . . . . . . . . . . 1

THE SULFEX-THOREX PROCESS . . . . . . . . . . . . . . . 2

Scouting Evaluations of Container Materials . . . . . . . . . . 3

Studies With Illium Alloys . . . . . . . . . . . . . . . . 5

Studies With Carpenter $20 \mathrm{Cb}$. . . . . . . . . . . . . 9

Cyclic-Exposure Evaluations . . . . . . . . . . . . . 9

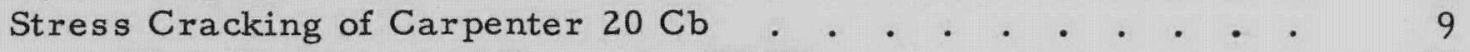

Heat Treatment of Carpenter $20 \mathrm{Cb}$. . . . . . . . 14

The Effect of Solution Composition on Corrosion . . . . . . 14

Galvanic Effects . . . . . . . . . . . . . 14

Studies With Ni-o-nel . . . . . . . . . . . . . . . 18

Cyclic Exposure Studies . . . . . . . . . . . . 18

Effects of Heat Treatments on the Intergranular
Corrosion of Ni-o-nel. . . . . . . . . . . . . . . 23

Effectiveness of Aluminum for Corrosion Control . . . . . . 23

Effects of Ions in the Decladding Solution . . . . . . . . . 23

Galvanic Effects During Decladding. . . . . . . . . . 27

Bench Dissolution of Fuel Pins by a Sulfex-Thorex Operation . . . . 30

THE DAREX-THOREX PROCESS . . . . . . . . . . . . . . . 45

Scouting Experiments With Titanium . . . . . . . . . . . . 45

Bench Dissolution of Fuel Pins by a Darex-Thorex Operation . . . . 51

THE ZIRFLEX PROCESS . . . . . . . . . . . . . . . . . . 62

POSSIBLE USE OF THE SAME VESSEL FOR THE ZIRFLEX

AND SULFEX-THOREX PROCESSES . . . . . . . . . . . . . . 68

THE ZIRCEX PROCESS

THE DAREX PROCESS . . . . . . . . . . . . . . . . . . . . 71

Dissolver Studies. . . . . . . . . . . . . . . . . 71

Titanium Steam Tubes . . . . . . . . . . . 76

Darex Transfer Lines . . . . . . . . . . . . 81

FAT Studies . . . . . . . . . . . . . . . . . . . 81

Chloride-Contaminated Purex Extraction Systems . . . . . . . . 85

Fission-Product-Recovery Solutions . . . . . . . . . . 86

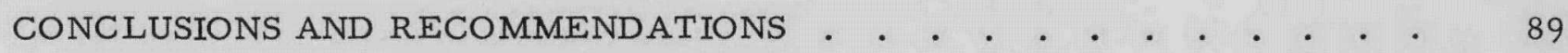


The Sulfex-Thorex Process . . . . . . . . . . . . . . 89

The Darex-Thorex Process . . . . . . . . . . . . 90

The Zirflex Process. . . . . . . . . . . . . . . . . . 91

Possible Use of the Same Vessel for the Zirflex and Sulfex-Thorex Processes . . . . . . . . . . . . . 91

The Zircex Process . . . . . . . . . . . . . . . . . . 91

The Darex Process . . . . . . . . . . . . . . 92

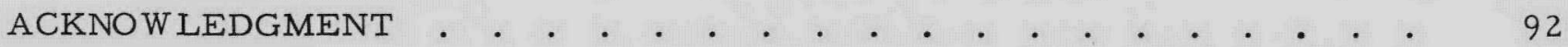

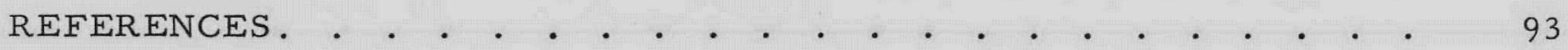

APPENDIX A

HEAT TREATMENT OF CARPENTER $20 \mathrm{Cb} . \quad$. . . . . . . . . . . A A

APPENDIX B

HEAT TREATMENT OF NI-O-NEL .

APPENDIX C

OBSERVATIONS CONCERNING SULFEX-THOREX DISSOLUTIONS . . . . C C-1

APPENDIX D

OBSERVATIONS CONCERNING DAREX-THOREX DISSOLUTIONS . . . . D D-1

APPENDIX E

COMPOSITIONS OF EVALUATED MATERIALS . • . • • . • . . . E-1 


\title{
CONSTRUCTION MATERIALS FOR VARIOUS HEAD-END PROCESSES \\ FOR THE AQUEOUS REPROCESSING OF SPENT FUEL ELEMENTS
}

\author{
Charles L. Peterson, Paul D. Miller, \\ James D. Jackson, and Frederick W. F'ink
}

\begin{abstract}
Materials of construction have been evaluated for use in critical areas of head-end processes for the aqueous reprocessing of spent nuclear fuel elements. The Sulfex-Thorex, Darex-Thorex, Darex, Zirflex, and Zircex processes were considered. The effect of varying heat treatments on the resistance of the materials was also evaluated. Dissolution of unirradiated fuel pins was carried out in vessels of promising materials.
\end{abstract}

The corrosion rate of Ni-o-nel was about 5 mils per month during actual fuel-pin dissolution by the Sulfex-Thorex process. Stabilization and heat treatment are necessary to prevent intergranular attack at welds. Carpenter $20 \mathrm{Cb}$ is subject to stress-corrosion cracking by the Sulfex decladding solution and Illium $R$ behaves similarly to Ni-o-nel in Thorex solutions.

Titanium shows promise as a construction material for a Darex-Thorex dissolver. However, several questions remain concerming a vapor-phase attack observed around certain weldments.

Carpenter $20 \mathrm{Cb}, \mathrm{Ni}-0-n e l$, and Types 309 and $309 \mathrm{~S} \mathrm{Cb}$ stainless steel appeared worthy of further study for the Zirflex dissolver. Preliminary evaluations show that at least Ni-o-nel and Carpenter $20 \mathrm{Cb}$ should be studied further as possible construction materials for a single vessel for Zirflex and Sulfex-Thorex processes.

Illium $R$, Hastelloy $C$, and nickel were not attacked by hydrochlorination conditions of the Zircex process. Minor attack was found on Inconel and Type S-816 alloy.

The corrosion of titanium was negligible in the Darex dissolver and feedadjustment system. The use of Type 304 ELC stainless steel lines for transferring Darex dissolver solution is not recommended. No corrosion of Type 347 stainless steel was observed after exposure for 2 years to chloride-contaminated Purex extraction systems at room temperature.

\section{INTRODUCTION}

The Chemical Technology Division of the Oak Ridge National Laboratory is developing new methods for processing the advanced fuel types now proposed for use in power reactors. Some results of this work have been reported by F. L. Culler and R. E. Blanco ("Dis solution and Feed Preparation for Aqueous Radiochemical Separations Processes", P/1930, Second United Nations International Conference on the Peaceful Uses of Atomic Energy, September 1-13, 1958) and by F. R. Bruce, R. E. Blanco, and J. C. Bresee ("Recent Developments in Feed Preparation and Solvent Extraction", 5th Nuclear Congress, Cleveland, Ohio, Apri1 7, 1959, ORNL-CF-11-91, March 20, 1959). The corrosion date presented in this report were obtained as a supplement to this development program.

Several aqueous processes have been devised by which the fissionable material is eventually recovered by means of conventional solvent extraction. These head-end 
processes, as they are known, usually involve a decladding step followed by core dissolution. This is especially true in the cases of fuel elements clad with stainless steel, zirconium, or Zircaloy.

Both decladding and core dissolution require the use of very corrosive solutions in order to effect dissolution of the materials in question. The difficulties arising from corrosion are further compounded by the economic desirability of handling both decladding and core dissolution in a single vessel.

A major portion of this report is devoted to corrosion studies associated with the Sulfex-Thorex process. In this process, primarily designed for thoria elements clad with stainless steel, decladding is accomplished with boiling $6 \mathrm{M} \mathrm{H}_{2} \mathrm{SO}_{4}$. The thoria core is then dissolved in boiling concentrated nitric acid containing a small addition of fluoride as a catalyst.

An alternative Darex-Thorex process was also investigated. In this case, dissolution of stainless steel is done with boiling dilute aqua regia in a titanium dissolver and dissolution of the thoria core is carried out in the same dissolver using the fluoride-catalyzed nitric acid solution.

A preliminary evaluation of container materials was made for the dissolver vessel of the Zirflex process wherein zirconium cladding is removed by boiling $6 \mathrm{M} \mathrm{NH}_{4} \mathrm{~F}+1 \mathrm{M} \mathrm{NH}_{4} \mathrm{NO}_{3}$ and dissolution of the thoria core is again accomplished with fluoride-catalyzed nitric acid solution. It was hoped that this process and the SulfexThorex process might be carried out in the same equipment, thus providing, in a single plant, the opportunity to process two types of fuel elements.

Previous corrosion investigations concerning the Zircex and Darex head-end processes have been reported in BMI-1242(1) and in an article in Industrial and Engineering Chemistry(2). Studies concerning these processes conducted subsequent to this literature are included in the present report. Among these are studies of the titanium dissolver, the feed-adjustment tank, the Purex solvent-extraction system, and the fission-product-recovery system of the Darex process.

\section{THE SULFEX-THOREX PROCESS}

Stainless steel is used to clad several types of nuclear fuels because it permits the elements to operate at a higher temperature than is possible with other common cladding materials. The Yankee Atomic Power Reactor and the Consolidated Edison Reactor will use fuel of this type.

Recovery of the fuel is difficult because of the resistance of the stainless steel to ordinary solvents. Several procedures have been proposed for reprocessing fuel clad in stainless steel. In one, known as the Sulfex process, the stainless steel can be removed from the core by boiling solutions of 4 or $6 \mathrm{M} \mathrm{H}_{2} \mathrm{SO}_{4}$.

The Chemical Technology Division of ORNL is considering the feasibility of using the Sulfex-Thorex process for reprocessing Consolidated Edison fuel elements (96 w/o thorium dioxide $-4 \mathrm{w} / \mathrm{o}$ uranium dioxide core). The core of this fuel would be dissolved (1) References at end of text. 
by the Thorex process, which uses boiling fluoride-catalyzed nitric acid solution as the solvent.

The ideal operation would permit the use of the same vessel for both decladding and core dissolution, since remote handling and maintenance of a two-vessel system would increase operating expenses considerably. The following sections of this report describe researches aimed at finding a material of construction which would withstand the operating conditions specified for both the Sulfex decladding and Thorex coredissolution processes.

In general, the method of attacking this problem has been to screen materials by a scouting-evaluation procedure in the more corrosive solutions to be encountered in the processes. The more promising materials indicated by these evaluations, in this case Carpenter $20 \mathrm{Cb}$ and $\mathrm{Ni}-\mathrm{o}-\mathrm{nel}$, were studied extensively. Experiments were performed in which the effects of heat treatments, ion accumulations in, or additions to, the solutions, and galvanic coupling were studied. Finally, vessels were constructed of these materials and actual pin dissolutions were carried out in Ni-o-nel. Similar dissolutions in the Carpenter $20 \mathrm{Cb}$ bench-scale dissolver are planned at ORNL. A parallel study was planned for at least one of the Illium alloys, but time did not permit conducting it.

\section{Scouting Evaluations of Container Materials}

Some preliminary work at ORNL indicated that Carpenter $20 \mathrm{Cb}$ was fairly resistant to Sulfex-Thorex conditions and warranted further study. Also, this material has found a useful place in the chemical industry for sulfuric acid service.

In preliminary studies, coupons made from Carpenter $20 \mathrm{Cb}$ were exposed to refluxing $6 \mathrm{M} \mathrm{H}_{2} \mathrm{SO}_{4}$ solutions at vapor, interface, and liquid locations. After $96 \mathrm{hr}$, the penetration rates (mils per month) varied from about 1.1 for specimens exposed to the vapor to 3.7 for specimens placed in the liquid. Thus, relatively good corrosion resistance was confirmed, considering the corrosiveness of boiling $6 \mathrm{M} \mathrm{H}_{2} \mathrm{SO}_{4}$.

Preliminary studies were also made in simulated Thorex solutions. The compositions used were:

$$
\begin{array}{ll}
\text { Initial } & 13.0 \mathrm{MHNO}_{3}, 0.05 \mathrm{M} \mathrm{F}^{-} \\
\text {Final } & 8.5 \mathrm{MHNO}_{3}, 0.05 \mathrm{M} \mathrm{F}^{-}, 1.0 \mathrm{MTh}\left(\mathrm{NO}_{3}\right)_{4}
\end{array}
$$

It was found that corrosion rates of the order of 50 mils per month were experienced in the Initial solution. This high rate appears to result from the fluoride content of this solution. Rates of less than 1 mil per month were noted for the Final solutions. The decreased corrosion was probably caused by the complexing of the fluoride by the thorium in the Final solutions. Other experience indicated that aluminum was an effective complexing agent in solutions of this type. (3) Accordingly, the effect of additions of aluminum and thorium nitrates to the Initial Thorex solution was investigated. It was found that the corrosion rate was reduced to less than $3 \mathrm{mils}$ per month by additions of $0.2 \mathrm{M} \mathrm{Al}^{+3}$. Figure 1 summarizes the data and shows the type of specimens used. 


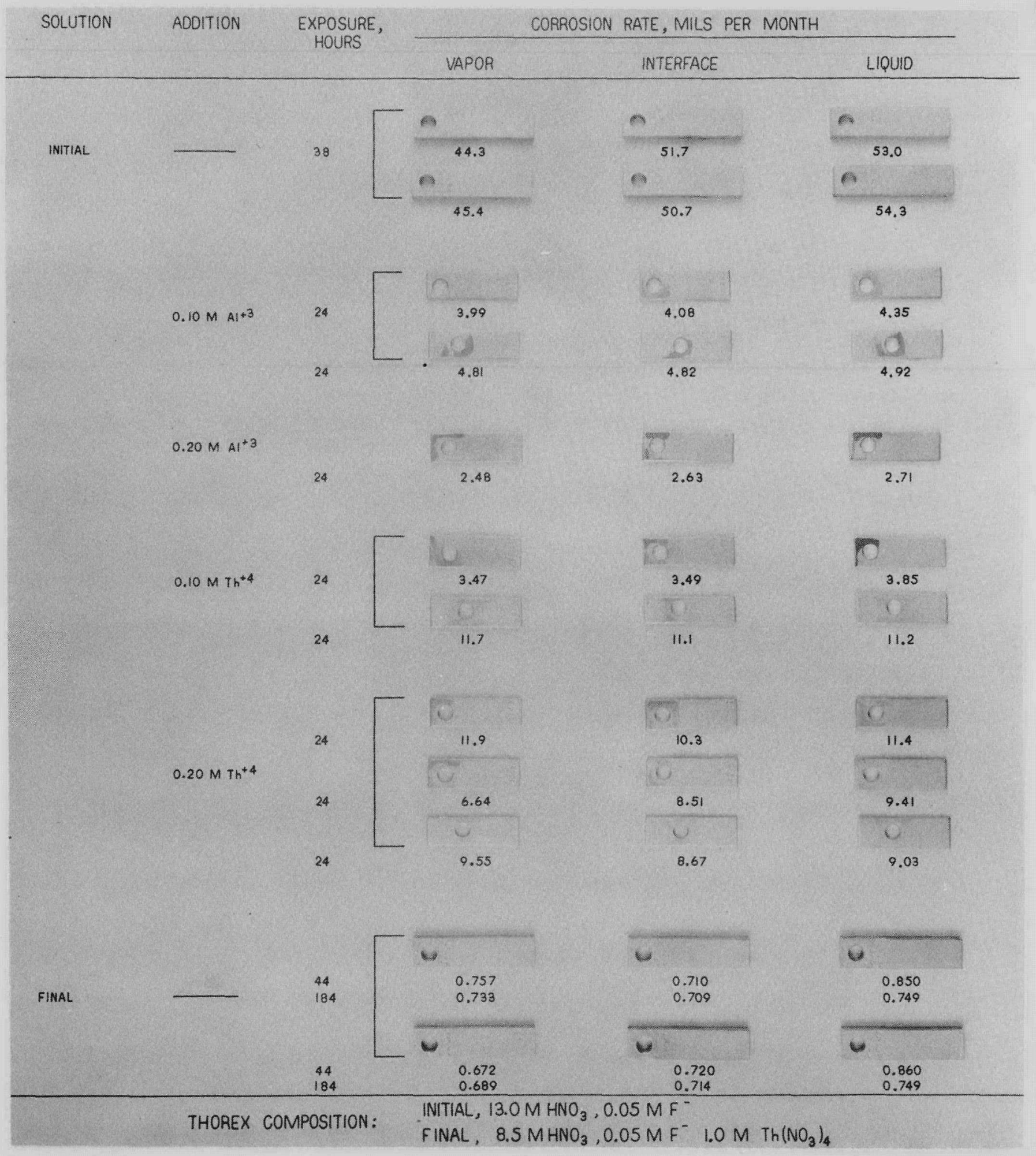

N5 1087

FIGURE 1. EFFECT OF EXPOSURE TO BOILING THOREX SOLUTIONS ON CARPENTER $20 \mathrm{Cb}$ ALLOY 
Fourteen other alloys in addition to Carpenter $20 \mathrm{Cb}$ were evaluated in $6 \mathrm{M} \mathrm{H}_{2} \mathrm{SO}_{4}$ and in Final Thorex solutions containing $0.2 \mathrm{M} \mathrm{Al}+3$. Table 1 lists the corrosion rates for these materials after an exposure of $24 \mathrm{hr}$. Figure 2 is a bar graph illustrating the same data graphically. (A tabulation of the compositions of these and other alloys will be found in Appendix E.) It can be seen that Type 319L, Type 329, Haynes 21, and Incoloy were quite resistant to the Thorex solutions. However, their resistance to $6 \mathrm{M} \mathrm{H}_{2} \mathrm{SO}_{4}$ was relatively poor. Zirconium was resistant to $\mathrm{H}_{2} \mathrm{SO}_{4}$, but not to Thorex solution. Carpenter $20 \mathrm{Cb}, \mathrm{Ni}-\mathrm{o}-\mathrm{nel}$, Illium $\mathrm{R}$, and Illium 98 showed fairly good resistance to both solutions. The results with Carpenter $20 \mathrm{Cb}$ and $\mathrm{Ni}-\mathrm{o}-\mathrm{nel}$ are discussed in later sections of this report. The results for the Illium alloys are presented below.

\section{Studies With Illium Alloys}

Small 1 by $1 / 2$-in. welded Illium $R$ specimens were exposed to Sulfex and Thorex solutions for three periods for a total of $120 \mathrm{hr}$. The data are given in Table 2. The corrosion rates were relatively low and of the same order as for the unwelded specimens reported in Table 1.

Microscopic examination showed general intergranular attack on the specimens exposed to Thorex solutions. This attack was slightly more severe in the heat-affected zone and great enough to eliminate this material from further consideration unles $s$ it can be improved by stabilization or heat treatment.

A series of scouting experiments was made with small 1 by $1 / 2$-in. welded specimens of Illium 98. This is an extra-low-carbon and-iron variation of Illium $R$. The data for 24 and $72 \mathrm{hr}$ of exposure are presented in Table 3. Excessive rates were observed in Initial Thorex solutions. The weldments were severely attacked. Aluminum additions were effective in controlling this, but intergranular attack was observed adjacent to the weldment. Incipient pitting occurred over the entire surfaces of specimens exposed to the liquid phases of 4 and $6 \mathrm{M} \mathrm{H}_{2} \mathrm{SO}_{4}$, being more pronounced in the higher concentration. No further studies were made with this alloy.

The producers of the Illium alloys are contemplating marketing a stabilized form of Illium R. In view of the promise shown by the Illium alloys, this new material should be evaluated thoroughly when it becomes available. In addition, perhaps a study of heat treatments of the presently marketed Illium $\mathrm{R}$ would prove worthwhile. 
TABLE 1. RESULTS OF SCOUTING EVALUA TIONS OF CONT AINER MATERI ALS FOR THE SULFEX - THOREX PROCESS

\begin{tabular}{|c|c|c|c|}
\hline \multirow[b]{2}{*}{ Specimen } & \multirow[b]{2}{*}{$\begin{array}{l}\text { Specimen } \\
\text { Position }\end{array}$} & \multicolumn{2}{|c|}{$\begin{array}{c}\text { Corrosion Rate For } 24 \mathrm{Hr} \text { in Solution Shown, } \\
\text { mils per month }\end{array}$} \\
\hline & & $\begin{array}{l}\text { Boiling Sulfex } \\
\left(6 \mathrm{M} \mathrm{H}_{2} \mathrm{SO}_{4}\right)\end{array}$ & $\begin{array}{c}\text { Boiling Initial Thorex } \\
\left(13.0 \mathrm{M} \mathrm{HNO}_{3}, 0.05 \mathrm{M} \mathrm{F}^{-}, 0.20 \mathrm{M} \mathrm{AI}^{+3}\right)\end{array}$ \\
\hline \multirow[t]{3}{*}{ Type 319L } & Vapor & Excessive & 2.0 \\
\hline & Interface & Excessive & 2.3 \\
\hline & Liquid & Excessive & 2.3 \\
\hline \multirow[t]{3}{*}{ Type 329} & Vapor & Excessive & 1.1 \\
\hline & Interface & Excessive & 1.0 \\
\hline & Liquid & Excessive & 1.2 \\
\hline \multirow[t]{3}{*}{$\mathrm{Ni}=\mathrm{O}-\mathrm{nel}$} & Vapor & 2.3 & 2.2 \\
\hline & Interface & 7.2 & 2.3 \\
\hline & Liquid & 7.3 & 2.3 \\
\hline \multirow{3}{*}{$\begin{array}{l}\text { Illium R } \\
\text { (as received) }\end{array}$} & Vapor & 0.36 & 2.0 \\
\hline & Interface & 3.8 & 1.9 \\
\hline & Liquid & 3.5 & 2.3 \\
\hline \multirow{2}{*}{$\begin{array}{l}\text { Illium R } \\
\text { (as welded) }\end{array}$} & Vapor & 1.1 & 2.8 \\
\hline & Liquid & 6.4 & 3.3 \\
\hline \multirow{2}{*}{$\begin{array}{l}\text { Illium } 98 \\
\text { (as welded) }\end{array}$} & Vapor & 1.4 & 2.9 \\
\hline & Liquid & 4.0 & 3.6 \\
\hline \multirow[t]{2}{*}{ Type S-590 } & Vapor & 1.9 & 4.8 \\
\hline & Liquid & 87 & 5.5 \\
\hline \multirow[t]{2}{*}{ Type S-816 } & Vapor & 3.0 & 5.3 \\
\hline & Liquid & 63 & 6.4 \\
\hline \multirow[t]{2}{*}{ Haynes 21} & Vapor & 1.7 & 1.6 \\
\hline & Liquid & 275 & 1.8 \\
\hline \multirow[t]{2}{*}{ Haynes 25} & Vapor & 2.8 & 4.9 \\
\hline & Liquid & 60 & 6.3 \\
\hline \multirow[t]{3}{*}{ Hastelloy C } & Vapor & 1.2 & 60 \\
\hline & Interface & 11 & 68 \\
\hline & Liquid & 14 & 67 \\
\hline \multirow[t]{3}{*}{ Hastelloy F } & Vapor & 2.5 & 5.5 \\
\hline & Interface & 65 & 4.1 \\
\hline & Liquid & 74 & 6.4 \\
\hline \multirow[t]{2}{*}{ Inconel 700} & Vapor & 1.9 & 21 \\
\hline & Liquid & Excessive & 44 \\
\hline \multirow[t]{2}{*}{ Incoloy 804} & Vapor & 124 & 1.3 \\
\hline & Liquid & Excessive & 1.2 \\
\hline \multirow[t]{3}{*}{ Zirconium } & Vapor & 0.023 & 4.3 \\
\hline & Interface & 0.097 & 99 \\
\hline & Liquid & 0.070 & 104 \\
\hline
\end{tabular}




$$
6.0 \mathrm{M} \mathrm{H}_{2} \mathrm{SO}_{4}
$$

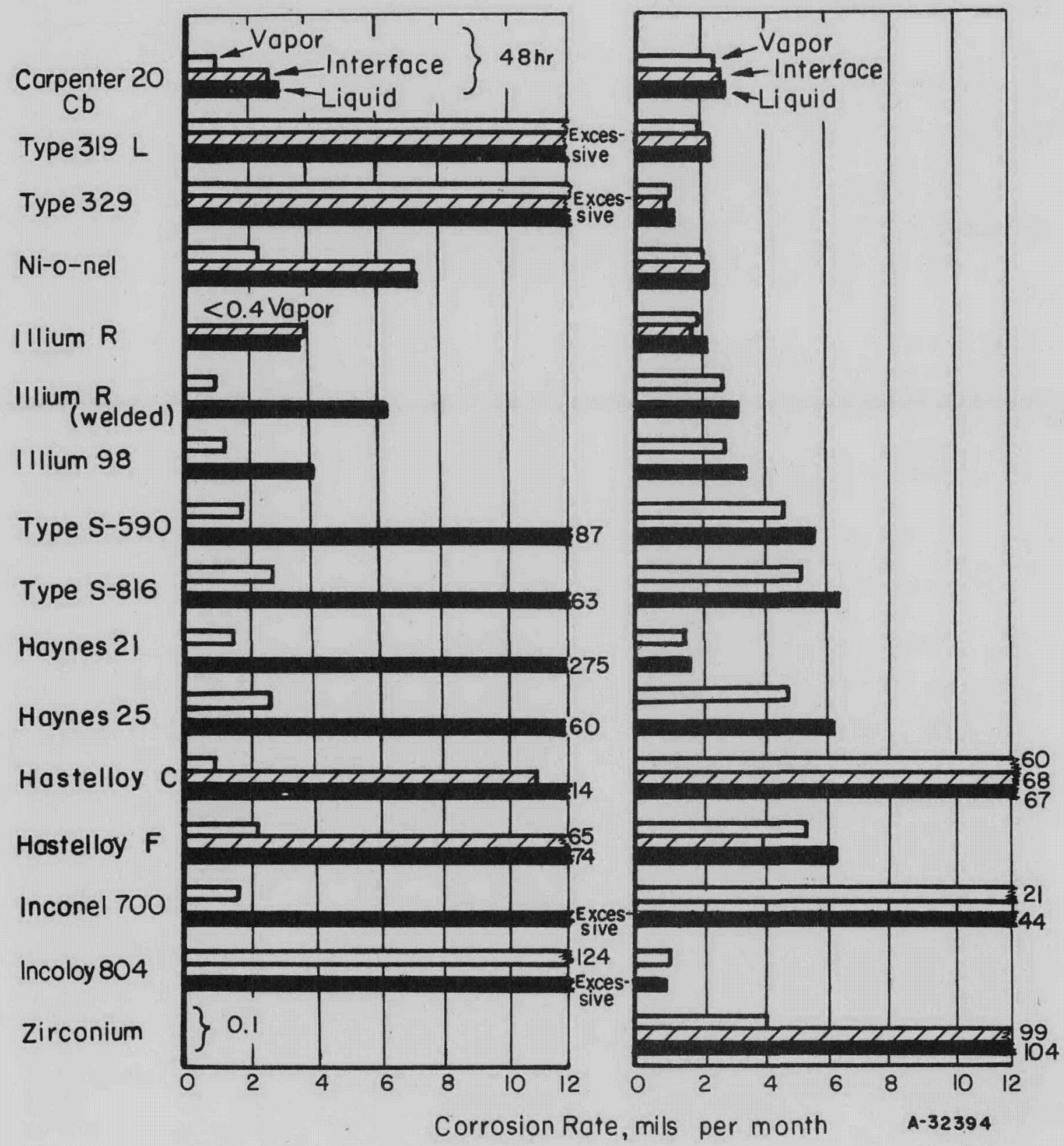

FIGURE 2. RESULTS OF SCOUTING EVALUATIONS OF CONTAINER MATERIALS FOR THE SULFEX-THOREX PROCESS

All specimens were exposed $24 \mathrm{hr}$ to boiling solutions except where noted. 
TABLE 2. RESULTS OF EXPOSURE OF WELDED ILLIUM R SPECIMENS IN SCOUTING EXPERIMENTS IN BOILING SULFEX-THOREX SOLUTIONS(a)

\begin{tabular}{|c|c|c|c|}
\hline \multirow[b]{2}{*}{ Solution } & \multirow{2}{*}{$\begin{array}{c}\text { Exposure, } \\
\mathrm{hr}\end{array}$} & \multicolumn{2}{|c|}{$\begin{array}{l}\text { Corrosion Rate at Position } \\
\text { Shown, mils per month }\end{array}$} \\
\hline & & Vapor & Liquid \\
\hline \multirow{3}{*}{$4 \mathrm{M} \mathrm{H}_{2} \mathrm{SO}_{4}$} & 24 & 0.36 & 2.9 \\
\hline & 72 & 0.30 & 1.7 \\
\hline & 120 & 0.41 & 1.8 \\
\hline \multirow{3}{*}{$6 \mathrm{M} \mathrm{H}_{2} \mathrm{SO}_{4}$} & 24 & 1.1 & 6.4 \\
\hline & 72 & 0.58 & 3.6 \\
\hline & 120 & 0.55 & 3.9 \\
\hline \multirow{3}{*}{$\begin{array}{l}\text { Initial Thorex }+ \\
0.2 \mathrm{M} \mathrm{Al}\left(\mathrm{NO}_{3}\right)_{3}(\mathrm{~b})\end{array}$} & 24 & 2.8 & 3.3 \\
\hline & 72 & 2.8 & 2.8 \\
\hline & 120 & 3.4 & 3.7 \\
\hline \multirow{3}{*}{$\begin{array}{l}\text { Final Thorex }+ \\
0.2 \mathrm{M} \mathrm{Al}\left(\mathrm{NO}_{3}\right)_{3}(\mathrm{~b})\end{array}$} & 24 & 1.2 & 1.6 \\
\hline & 72 & 1.0 & 1.5 \\
\hline & 120 & 1.0 & 1.6 \\
\hline
\end{tabular}

(a) Specimens exposed in same solution for two periods, fresh solution for third period.

(b) Solution compositions:

$$
\begin{aligned}
& \text { Initial Thorex } \quad 13.0 \mathrm{M} \mathrm{HNO}_{3}, 0.05 \mathrm{MF}^{-} \\
& \text {Final Thorex } \\
& \text { 8.5 } \mathrm{M} \mathrm{HNO}_{3}, 0.05 \mathrm{M} \mathrm{F}^{-}, 1.0 \mathrm{M} \mathrm{Th}\left(\mathrm{NO}_{3}\right)_{4} \text {. }
\end{aligned}
$$

TABLE 3. RESULTS OF SCOUTING EXPERIMENTS WITH WELDED ILLIUM 98

\begin{tabular}{|c|c|c|c|c|}
\hline \multirow[b]{3}{*}{ Solution } & \multicolumn{4}{|c|}{ Corrosion Rate at Position Shown, mils per month } \\
\hline & \multicolumn{2}{|c|}{ Vapor } & \multicolumn{2}{|c|}{ Liquid } \\
\hline & $24 \mathrm{Hr}$ & $72 \mathrm{Hr}$ & $24 \mathrm{Hr}$ & $72 \mathrm{Hr}$ \\
\hline $4 \mathrm{M} \mathrm{H}_{2} \mathrm{SO}_{4}$ & 0.07 & 0.16 & 1.4 & 1.1 \\
\hline $6 \mathrm{M} \mathrm{H}_{2} \mathrm{SO}_{4}$ & 1.4 & 0.66 & 4.0 & 2. 8 \\
\hline Initial Thorex $(a)$ & 59 & 98 & 85 & 112 \\
\hline $\begin{array}{l}\text { Initial Thorex }+ \\
0.2 \mathrm{M} \mathrm{Al}\left(\mathrm{NO}_{3}\right)_{3}\end{array}$ & 2.9 & 3.7 & 3.6 & 3.6 \\
\hline Final Thorex(a) & 0.54 & 1.7 & 1.8 & 3.0 \\
\hline $\begin{array}{l}\text { Final Thorex }+ \\
0.2 \mathrm{M} \mathrm{Al}\left(\mathrm{NO}_{3}\right)_{3}\end{array}$ & 1.3 & 1.4 & 1.7 & 1.6 \\
\hline
\end{tabular}
SPECIMENS IN BOILING SULFEX AND THOREX SOLUTIONS

(a) Solution compositions:

Initial Thorex

Final Thorex

13. $0 \mathrm{M} \mathrm{HNO}_{3}, 0.05 \mathrm{M} \mathrm{F}^{-}$

$8.5 \mathrm{M} \mathrm{HNO}_{3}, 0.05 \mathrm{M} \mathrm{F}^{-}, 1.0 \mathrm{M} \operatorname{Th}\left(\mathrm{NO}_{3}\right)_{4}$. 
Studies With Carpenter $20 \mathrm{Cb}$

Cyclic-Exposure Evaluations

The corrosion of Carpenter $20 \mathrm{Cb}$ under alternate exposure to Sulfex and Thorex solutions was determined. Specimens were cycled from one solution to another in two arbitrarily chosen systems. System I consisted of a 3-hr exposure to boiling $6 \mathrm{M} \mathrm{H}_{2} \mathrm{SO}_{4}$ followed by a $5-\mathrm{hr}$ exposure to a boiling solution simulating the final composition of core dissolution [ $8.5 \mathrm{M} \mathrm{HNO}_{3}, 0.050 \mathrm{M} \mathrm{F}^{-}, 1.0 \mathrm{MTh}\left(\mathrm{NO}_{3}\right)_{3}, 0.20 \mathrm{M}$ $\left.\mathrm{Al}\left(\mathrm{NO}_{3}\right)_{3}\right]$. System II employed exposures of similar duration to boiling $4 \mathrm{M} \mathrm{H}_{2} \mathrm{SO}_{4}$

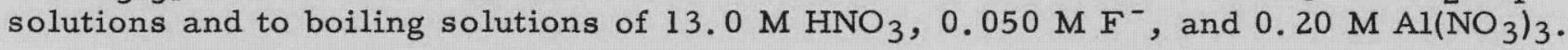

Six specimens of as-welded Carpenter $20 \mathrm{Cb}$ (duplicates in the vapor, interface, and liquid positions) were cycled in each system. Specimens were also exposed only to one of each of the four solutions, simultaneously with exposure of the cycled specimens. All specimens were thoroughly washed between exposures and weight losses were measured after $2,5,10,15$, and 20 cycles. The data are shown in Table 4 and plotted in Figures 3 and 4.

In both systems, the highest corrosion rates (up to 6 mils per month) occurred on the liquid-phase specimens. All the corrosion rates decreased as the length of exposure increased. Exposure to System II resulted in more corrosion than exposure to System I. The data indicate that cycling does not lead to a more aggressively corrosive environment.

Stress Cracking of Carpenter $20 \mathrm{Cb}$

Microscopic examination of the specimens following 10 and 20 cycles revealed a number of transgranular cracks on surfaces which had been heavily deformed by stamping, and on sheared edges. These were found only on specimens exposed to sulfuric acid solutions alone, or cycled to sulfuric acid (see Figure 5). Cracking was somewhat more pronounced on specimens exposed to the more concentrated ( $6 \mathrm{M})$ acid. A few specimens showed signs of cracking on undeformed surfaces and along weldments. Intergranular attack was occasionally observable on specimens exposed to the Thorex solutions. Photomicrographs of sections cut through typical specimens after 10 cycles are shown in Figure 6.

The specimens used in the cyclic exposure just described were cut from 16-gage stock. The results were confirmed with 11 -gage metal from another stock. Specimens cut from this material were compared with some from the 16-gage material by exposing both to the liquid phase of boiling $6 \mathrm{M} \mathrm{H}_{2} \mathrm{SO}_{4}$ for $48 \mathrm{hr}$. The surfaces of both sets of specimens were heavily deformed by imprinting with steel stamps. Much less cracking occurred in the thicker sheet material. It is thought that this was not so much a case of different heats of Carpenter $20 \mathrm{Cb}$ as a situation in which higher residual surface stresses are induced in the thin material upon stamping than are imparted to the thick material.

Research conducted by the producer of Carpenter $20 \mathrm{Cb}$ confirmed the occurrence of cracking upon exposure to boiling $\mathrm{H}_{2} \mathrm{SO}_{4}$ in the 30 to $35 \mathrm{w} / 0$ range. These investigators report that cracking is most likely to occur under conditions which cause copper 
TABLE 4. CORROSION OF WELDED CARPENTER $20 \mathrm{Cb}$ DURING CYCLIC STUDIES IN BOILING SULFEX-THOREX SOLUTIONS

\begin{tabular}{|c|c|c|c|c|c|c|c|c|c|c|c|c|c|}
\hline \multirow[b]{4}{*}{ Periods } & \multirow[b]{4}{*}{$\begin{array}{c}\text { Specimen } \\
\text { Position }\end{array}$} & \multicolumn{12}{|c|}{ Corrosion Rate, mils per month } \\
\hline & & \multicolumn{6}{|c|}{ For System I Exposures } & \multicolumn{6}{|c|}{ For System II Exposures } \\
\hline & & \multicolumn{3}{|c|}{ Not Cycled } & \multicolumn{3}{|c|}{ Cycled (A to B) } & \multicolumn{3}{|c|}{ Not Cycled } & \multicolumn{3}{|c|}{ Cycled (C to D) } \\
\hline & & $\begin{array}{c}\mathrm{A} \\
\left(6 \mathrm{M} \mathrm{H}_{2} \mathrm{SO}_{4}\right. \\
3 \mathrm{Hr})\end{array}$ & $\begin{array}{c}\text { B } \\
(\text { Final Thorex } \\
5 \mathrm{Hr})^{(\mathrm{a})}\end{array}$ & $\begin{array}{l}\text { Weighted } \\
\text { Value for } \\
A+B(b)\end{array}$ & $\begin{array}{c}\text { First } \\
\text { Set }\end{array}$ & $\begin{array}{c}\text { Duplicate } \\
\text { Set }\end{array}$ & Average & $\begin{array}{c}\mathrm{C} \\
\left(4 \mathrm{M} \mathrm{H}_{2} \mathrm{SO}_{4}\right. \\
3 \mathrm{Hr})\end{array}$ & $\begin{array}{c}\text { D } \\
\text { (Initial Thorex, } \\
5 \mathrm{Hr})^{(\mathrm{a})}\end{array}$ & $\begin{array}{c}\text { Weighted } \\
\text { Value for } \\
C+D\end{array}$ & $\begin{array}{c}\text { First } \\
\text { Set }\end{array}$ & $\begin{array}{c}\text { Duplicate } \\
\text { Set }\end{array}$ & Average \\
\hline \multirow[t]{3}{*}{2} & Vapor & 1.2 & 2.0 & 1.7 & 1.5 & 1.6 & 1.6 & 1.3 & 5.4 & 3.9 & 3.6 & 3.7 & 3.6 \\
\hline & Interface & 4.9 & 2.3 & 3.3 & 2.8 & 3.0 & 2.9 & 5.1 & 5.7 & 5.4 & 4.8 & 4.9 & 4.9 \\
\hline & Liquid & 5.0 & 2.6 & 3.5 & 3.0 & 3.0 & 3.0 & 5.1 & 6.2 & 5.8 & 4.7 & 4.9 & 4.8 \\
\hline \multirow[t]{3}{*}{5} & Vapor & 1.1 & 1.5 & 1.4 & 1.1 & 1.2 & 1.1 & 0.93 & 4.3 & 3. 1 & 2.7 & 2.7 & 2.7 \\
\hline & Interface & 5.4 & 1.8 & 3.1 & 2.1 & 2.2 & 2.2 & 4.7 & 4.1 & 4.3 & 3.5 & 3.6 & 3.5 \\
\hline & Liquid & 5.7 & 1.9 & 3.3 & 2.3 & 2.3 & 2.3 & 4.7 & 4.6 & 4.6 & 3.5 & 3.6 & 3.5 \\
\hline \multirow[t]{3}{*}{10} & Vapor & 0.87 & 1.3 & 1.1 & 0.89 & 0.91 & 0.90 & 0.75 & 3.6 & 2.6 & 2.2 & 2.2 & 2.2 \\
\hline & Interface & 3.4 & 1.5 & 2.2 & 1.7 & 1.7 & 1.7 & 2.9 & 3.5 & 3.3 & 2.9 & 3.0 & 2.9 \\
\hline & Liquid & 4.2 & 1.6 & 2.6 & 1.8 & 1.7 & 1.8 & 2.6 & 3.8 & 3.3 & 3.0 & 3.0 & 3.0 \\
\hline \multirow[t]{3}{*}{15} & Vapor & 0.82 & 1.1 & 1.0 & 0.80 & 0.80 & 0.80 & 0.61 & 3.0 & 2.1 & 1.9 & 1.9 & 1.9 \\
\hline & Interface & 2.8 & 1.3 & 1.9 & 1.5 & 1.5 & 1.5 & 2.3 & 2.9 & 2.7 & 2.5 & 2.5 & 2.5 \\
\hline & Liquid & 3.9 & 1.4 & 2.3 & 1.7 & - & 1.7 & 2.5 & 3.1 & 2.9 & 2.5 & 2.5 & 2.5 \\
\hline \multirow[t]{3}{*}{20} & Vapor & 0.68 & 1.0 & 0.91 & 0.74 & 0.74 & 0.74 & 0.53 & 2.8 & 1.9 & 1.7 & 1.7 & 1.7 \\
\hline & Interface & 2.5 & 1.2 & 1.7 & 1.5 & -- & 1.5 & 2.0 & 2.6 & 2.4 & 2.3 & 2.3 & 2.3 \\
\hline & Liquid & 3.3 & 1.3 & 2.1 & 1.6 & - & 1.6 & 2.2 & 2.8 & 2.6 & 2.3 & 2.3 & 2.3 \\
\hline
\end{tabular}

Solution compositions:
Initial Thorex $13.0 \mathrm{MNO}_{3}, 0.050 \mathrm{M} \mathrm{F}^{-}, 0.20 \mathrm{M} \mathrm{Al}\left(\mathrm{NO}_{3}\right)_{3}$

Final Thorex $8.5 \mathrm{M} \mathrm{HNO}_{3}, 0.050 \mathrm{M} \mathrm{F}^{-}, 1.0 \mathrm{M} \mathrm{Th}\left(\mathrm{NO}_{3}\right)_{4}, 0.20 \mathrm{M} \mathrm{Al}\left(\mathrm{NO}_{3}\right)_{3}$.

(b) The weighted values are calculated as follows: $\frac{(3 \times 1.2)+(5 \times 2.0)}{8}=1.7$ mils per month. 


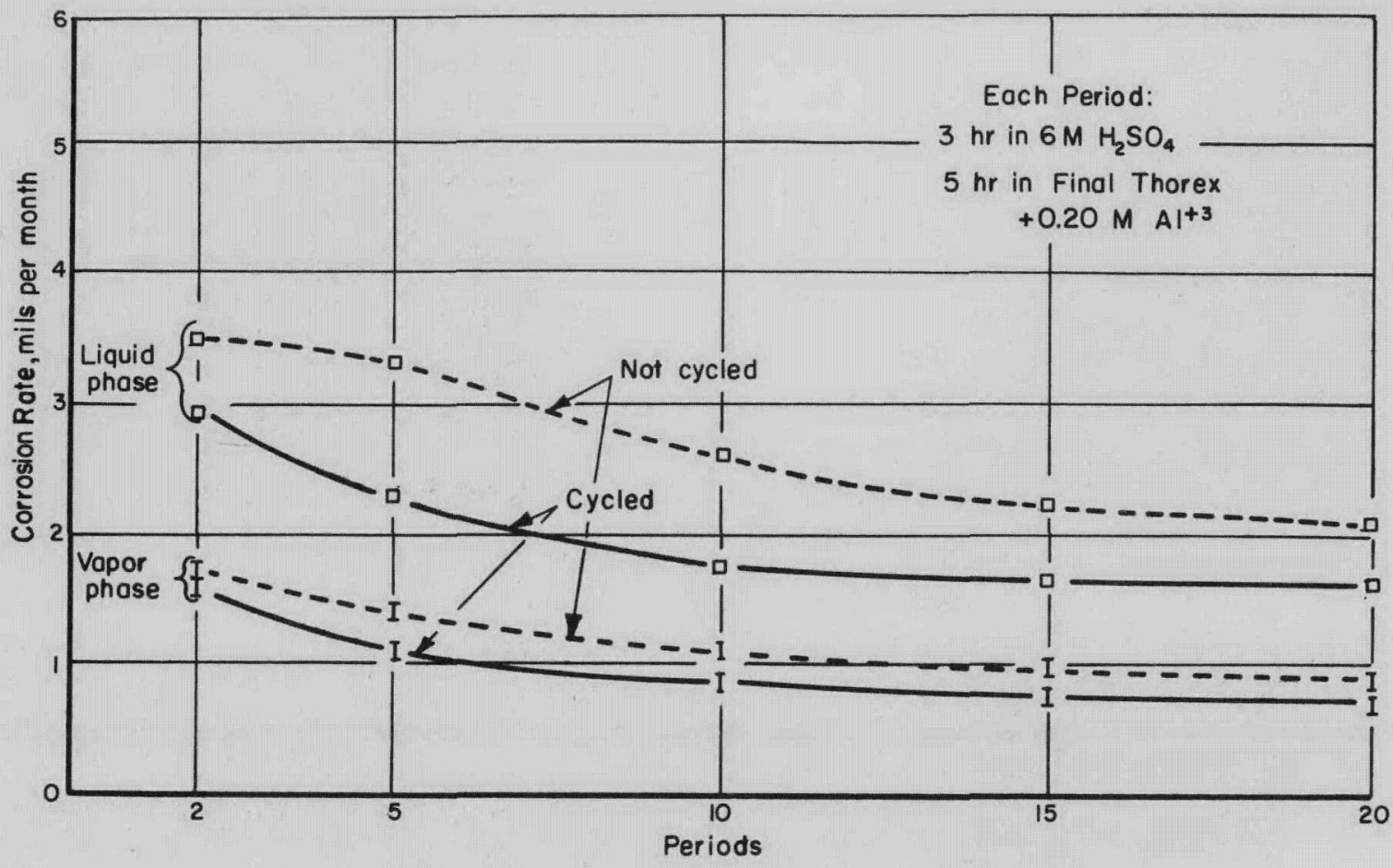

FIGURE 3. CORROSION OF WELDED CARPENTER $20 \mathrm{Cb}$ DURING CYCLIC STUDIES IN BOILING SULFEX-THOREX SOLUTIONS (SYSTEM I)

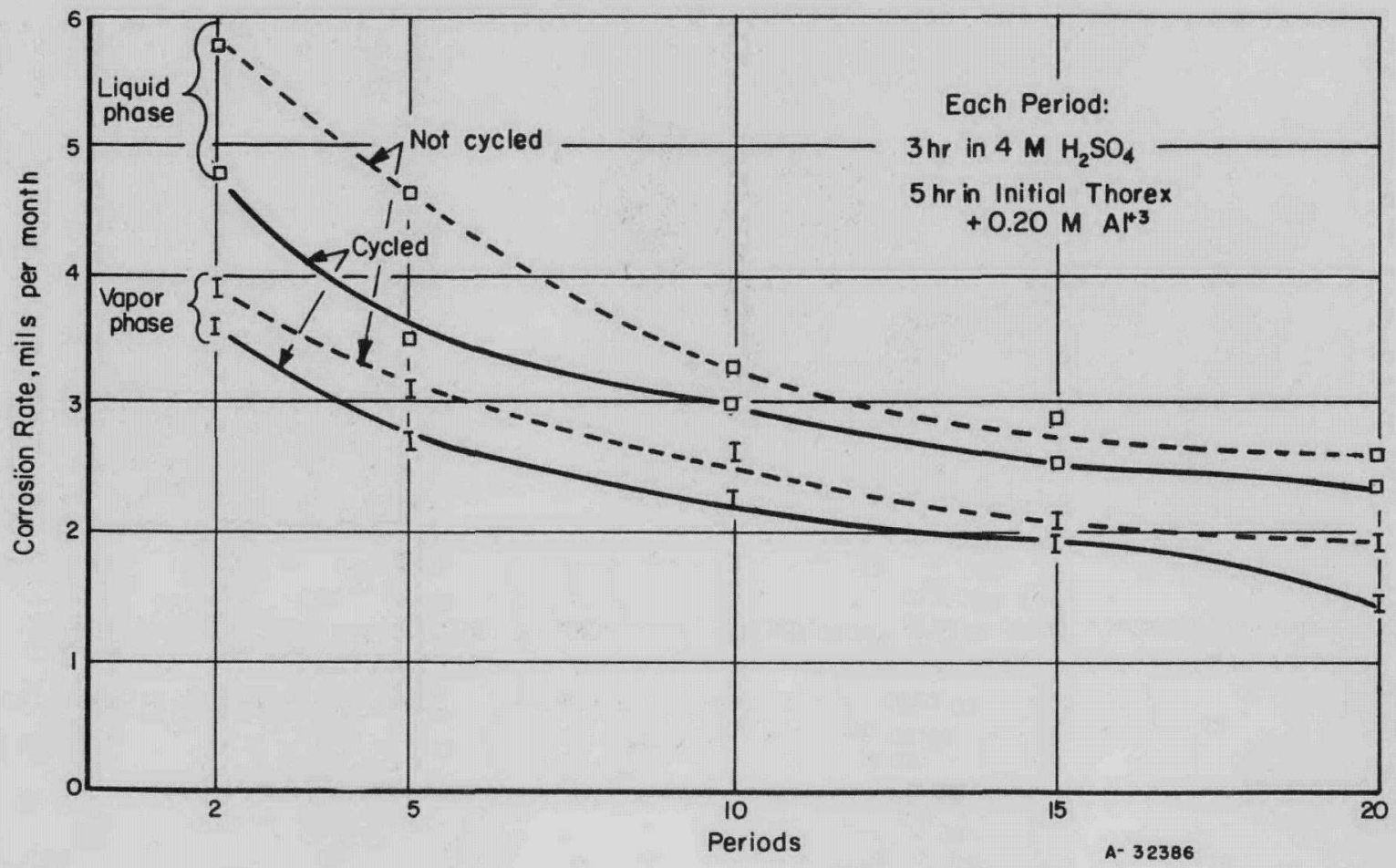

FIGURE 4. CORROSION OF WELDED CARPENTER $20 \mathrm{Cb}$ DURING CYCLIC STUDIES IN BOILING SULFEX-THOREX SOLUTIONS (SYSTEM II) 

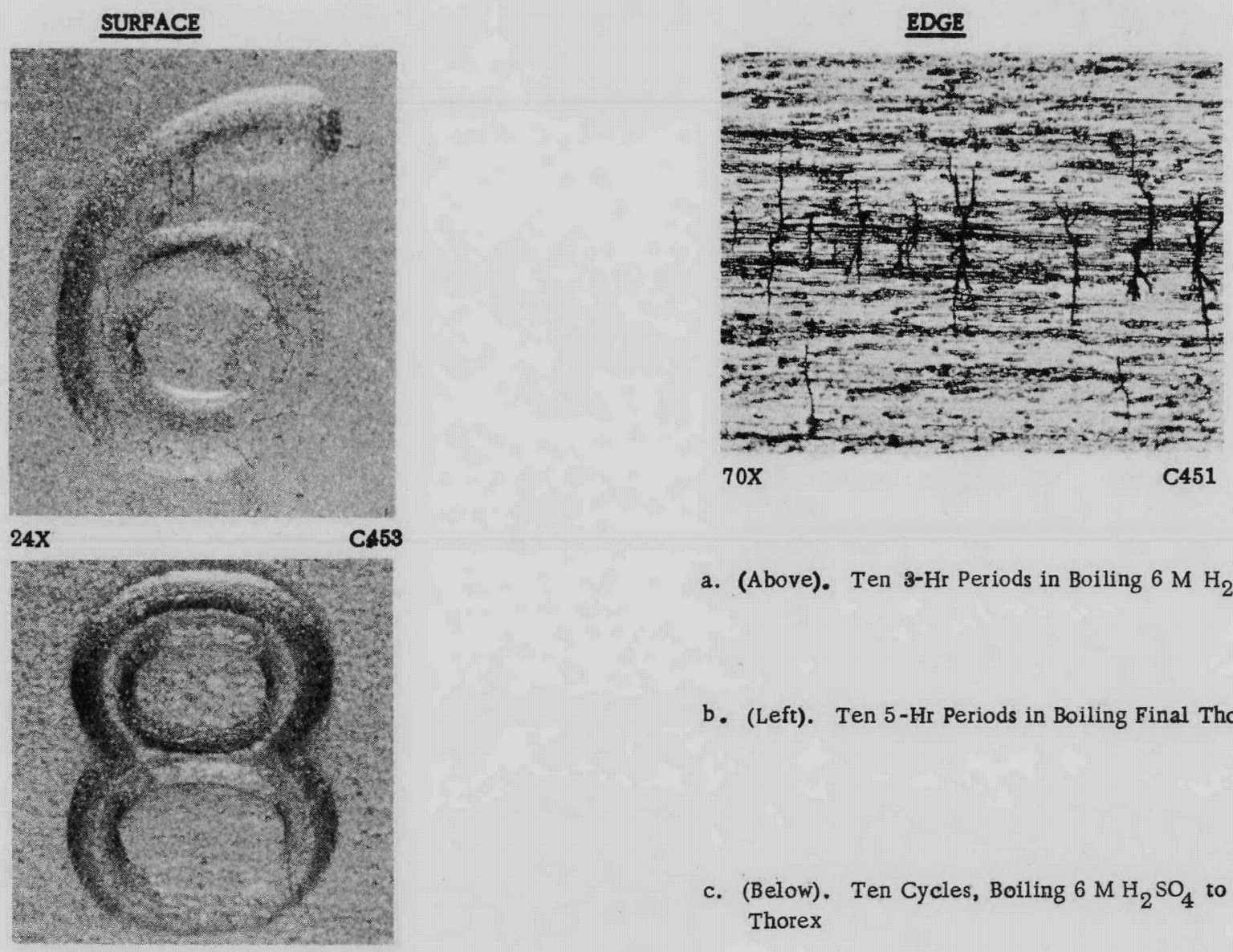

a. (Above). Ten $3-\mathrm{Hr}$ Periods in Boiling $6 \mathrm{M} \mathrm{H}_{2} \mathrm{SO}_{4}$

b. (Left). Ten 5-Hr Periods in Boiling Final Thorex

$24 X$

C454

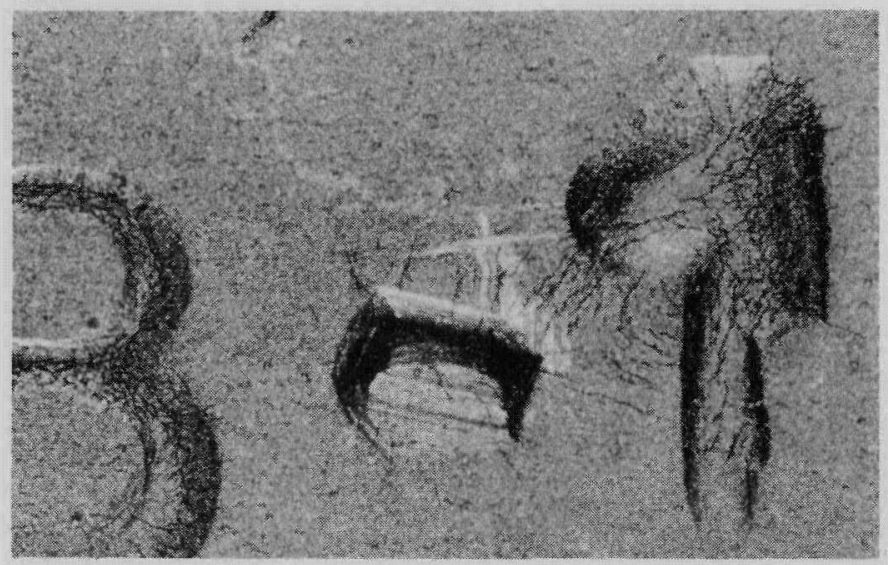

$\mathrm{C} 455$

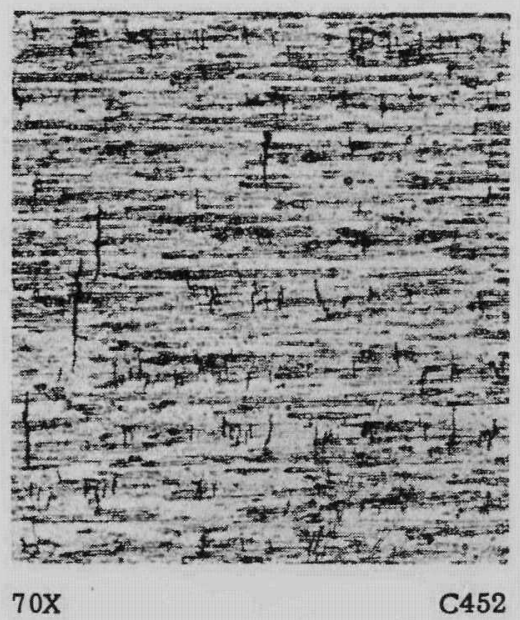

FIGURE 5. PHOTOMICROGRAPHS OF CARPENTER $20 \mathrm{Cb}$ EXPOSED IN BOILING $6 \mathrm{M} \mathrm{H}_{2} \mathrm{SO}_{4}$ + FINAL THOREX

Transgranular cracks on deformed surfaces or sheared edges occurred only on specimens exposed to sulfuric acid alone or cycled to sulfuric acid.

c. (Below). Ten Cycles, Boiling $6 \mathrm{M} \mathrm{H}_{2} \mathrm{SO}_{4}$ to Final Thorex 


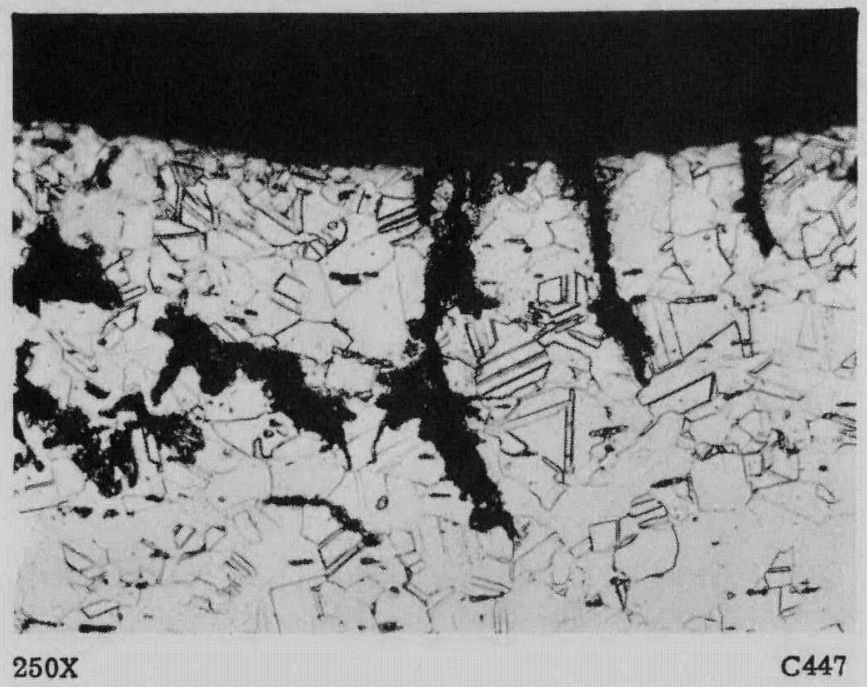

a. Longitudinal Section Along Number

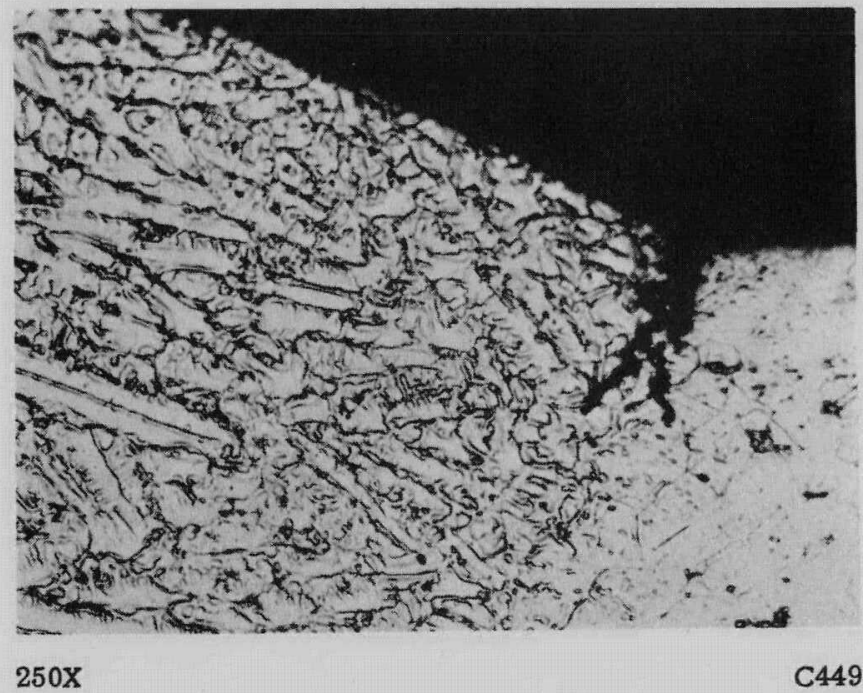

c. Edge of Weldment

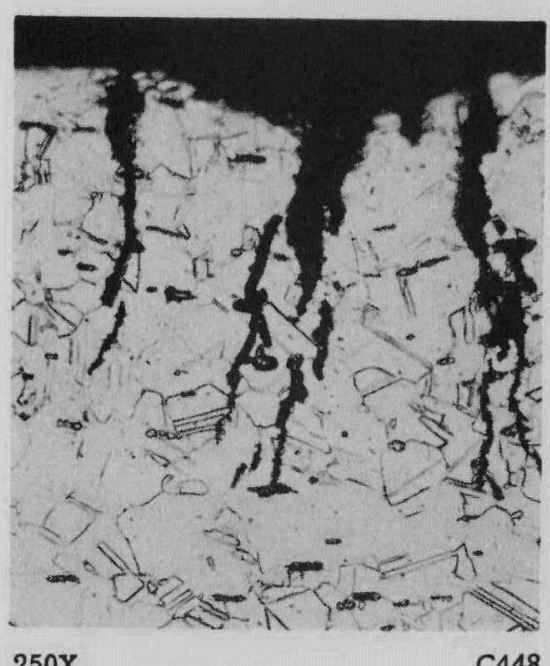

b. Transverse Section Along Number

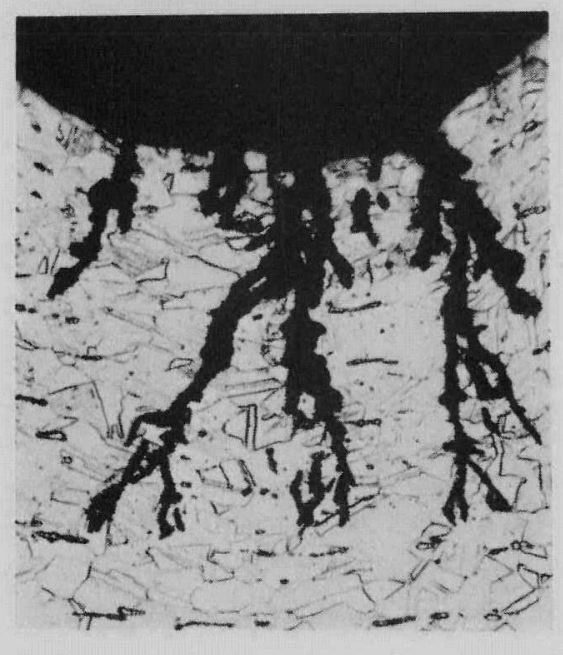

250X

C450

d. Transverse Section Along Number

FIGURE 6. PHOTOMICROGRAPHS OF SECTIONS THROUGH CARPENTER 20 Cb FOLLOWING 10 CYCLES FROM BOILING $6 \mathrm{M} \mathrm{H}_{2} \mathrm{SO}_{4}$ TO FINAL THOREX

Exposure to the $6 \mathrm{M} \mathrm{H}_{2} \mathrm{SO}_{4}$ produced somewhat more pronounced cracking in specimens than occurred in the $4 \mathrm{M}$ solution (Figure 5). Some specimens showed attack on undeformed surfaces and along weldments. 
to plate upon the surface. Apparently, this happens only in a relatively narrow zone of $\mathrm{H}_{2} \mathrm{SO}_{4}$ concentration. At $60 \mathrm{w} / 0 \mathrm{H}_{2} \mathrm{SO}_{4}$, the corrosion rate is high but cracking does not occur, according to their observations. (4)

Heat Treatment of Carpenter $20 \mathrm{Cb}$. It was found that the stresses could be relieved by heating at 1950 to $2050 \mathrm{~F}$ and quenching rapidly. However, subsequent deformation of the metal surface produced stresses which caused cracking when the specimens were exposed to boiling $6 \mathrm{M} \mathrm{H}_{2} \mathrm{SO}_{4}$. Appendix A includes a detailed discussion of the heat treatments which were investigated.

\section{The Effect of Solution Composition on Corrosion}

The Sulfex decladding solutions will consist of uncontaminated $\mathrm{H}_{2} \mathrm{SO}_{4}$ only for short periods at the start of each decladding operation. Investigators at ORNL have shown that it is necessary to introduce the fuel pins into uncontaminated $\mathrm{H}_{2} \mathrm{SO}_{4}$, at or near its boiling point, to avoid complications arising from possible passivation of the stainless steel jackets. (5) Previous experience has shown that, in general, as a solution builds up in dissolved stainless steel, it becomes less corrosive. Experiments were conducted in which specimens of Carpenter $20 \mathrm{Cb}$ were exposed to boiling $6 \mathrm{M} \mathrm{H}_{2} \mathrm{SO}_{4}$ solution containing various additions of chromium, iron, and nickel salts combined in the ratio that would result from the dissolution of Type 304 ELC stainless steel jackets. The results of these experiments appear in Table 5, and the specimens are shown, following exposure, in Figure 7.

The presence of the chromium, iron, and nickel salts brought about a substantial reduction in corrosion rates, being an order of magnitude smaller with the equivalent of 5 or more g per liter of dissolved stainless steel present. Also, the susceptibility of the material to cracking was altered. Cracking occurred in the presence of $1 \mathrm{~g}$ per liter dissolved stainless steel during the first $48 \mathrm{hr}$ of exposure. With 5 or more g per liter, cracking was not observed. The specimens from the latter conditions remained bright and shiny throughout the exposure. By the end of $116 \mathrm{hr}$ of exposure, cracking was quite apparent on specimens exposed to the $1 \mathrm{~g}$ per liter addition. In this case, slight cracking occurred on the submerged specimens but much more cracking was observed on specimens exposed at the interface position, especially on the areas immediately above the liquid line. These interface specimens also showed the highest corrosion rates of any in this set.

\section{Galvanic Effects}

Not only can the presence of dissolved stainless steel in the Sulfex solutions be expected to provide corrosion inhibition, but, in addition, some cathodic protection of immersed Carpenter $20 \mathrm{Cb}$ specimens would be expected from contact with the dissolving fuel elements acting as sacrificial stainless steel anodes. Studies of this action were made. Type 304 stainless steel rods were dissolved in boiling acid while resting on a coupon of Carpenter $20 \mathrm{Cb}$ containing stressed areas. 
TABLE 5. CORROSION OF CARPENTER $20 \mathrm{Cb}$ IN BOILING SULFEX ( $\left.6 \mathrm{M} \mathrm{H}_{2} \mathrm{SO}_{4}\right)$ SOLUTIONS CONTAINING CHROMIUM, IRON, AND NICKEL SALTS

\begin{tabular}{|c|c|c|c|c|c|c|c|}
\hline \multirow{2}{*}{$\begin{array}{c}\text { Equivalent } \\
\text { Type } 304 \text { ELC Stainless, } \\
\text { g per liter }\end{array}$} & \multirow[b]{2}{*}{$\begin{array}{l}\text { Specimen } \\
\text { Position }\end{array}$} & \multirow[b]{2}{*}{$\begin{array}{c}\text { Exposure, } \\
\mathrm{hr}\end{array}$} & \multicolumn{2}{|c|}{$\begin{array}{l}\text { Corrosion Rate, } \\
\text { mils per month }\end{array}$} & \multirow[b]{2}{*}{$\begin{array}{c}\text { Exposure, } \\
\mathrm{hr}\end{array}$} & \multicolumn{2}{|c|}{$\begin{array}{l}\text { Corrosion Rate, } \\
\text { mils per month }\end{array}$} \\
\hline & & & $\begin{array}{c}16-\text { Gage } \\
\text { Specimens }\end{array}$ & $\begin{array}{l}11-\text { Gage } \\
\text { Specimens }\end{array}$ & & $\begin{array}{c}16-G \text { age } \\
\text { Specimens }\end{array}$ & $\begin{array}{c}11-\text { Gage } \\
\text { Specimens }\end{array}$ \\
\hline \multirow[t]{3}{*}{0.0} & Vapor & 48 & 1.1 & 1.1 & 96 & 1,1 & 1.2 \\
\hline & Interface & 48 & 2.7 & 2.2 & 96 & 3.0 & 2.6 \\
\hline & Liquid & 48 & 3.0 & 2.6 & 96 & 3.7 & 3.2 \\
\hline \multirow[t]{3}{*}{0.0} & Vapor & 68 & 1.7 & -- & -- & -- & -- \\
\hline & Interface & 68 & 2.7 & -- & -- & -- & -- \\
\hline & Liquid & 68 & 2.8 & -- & -- & -- & $-\infty$ \\
\hline \multirow[t]{3}{*}{1.0} & Vapor & 48 & 0.44 & 0.93 & 116 & 0.92 & 1.2 \\
\hline & Interface & 48 & 0.66 & 5.3 & 116 & 2.7 & 4.7 \\
\hline & Liquid & 48 & 0.71 & 2.8 & 116 & 1.5 & 2.3 \\
\hline \multirow[t]{3}{*}{5.0} & Vapor & 48 & 0.13 & 0.42 & 96 & 0.06 & 0.22 \\
\hline & Interface & 48 & 0.31 & 0.31 & 96 & 0.32 & 0.31 \\
\hline & Liquid & 48 & 0.36 & 0.33 & 96 & 0.36 & 0.32 \\
\hline \multirow[t]{3}{*}{$35.0(a)$} & Vapor & 48 & 0.07 & $=\ldots$ & -- & -- & -- \\
\hline & Interface & 48 & 0.31 & -- & -- & -- & -- \\
\hline & Liquid & 48 & 0.34 & -- & -- & -- & -- \\
\hline
\end{tabular}

(a) Approximately $25.2 \mathrm{~g}$ per liter $\mathrm{Fe}^{++}, 6.9 \mathrm{~g}$ per liter $\mathrm{Cr}^{+6}$, and 2.8 per liter $\mathrm{Ni}^{++}$. 


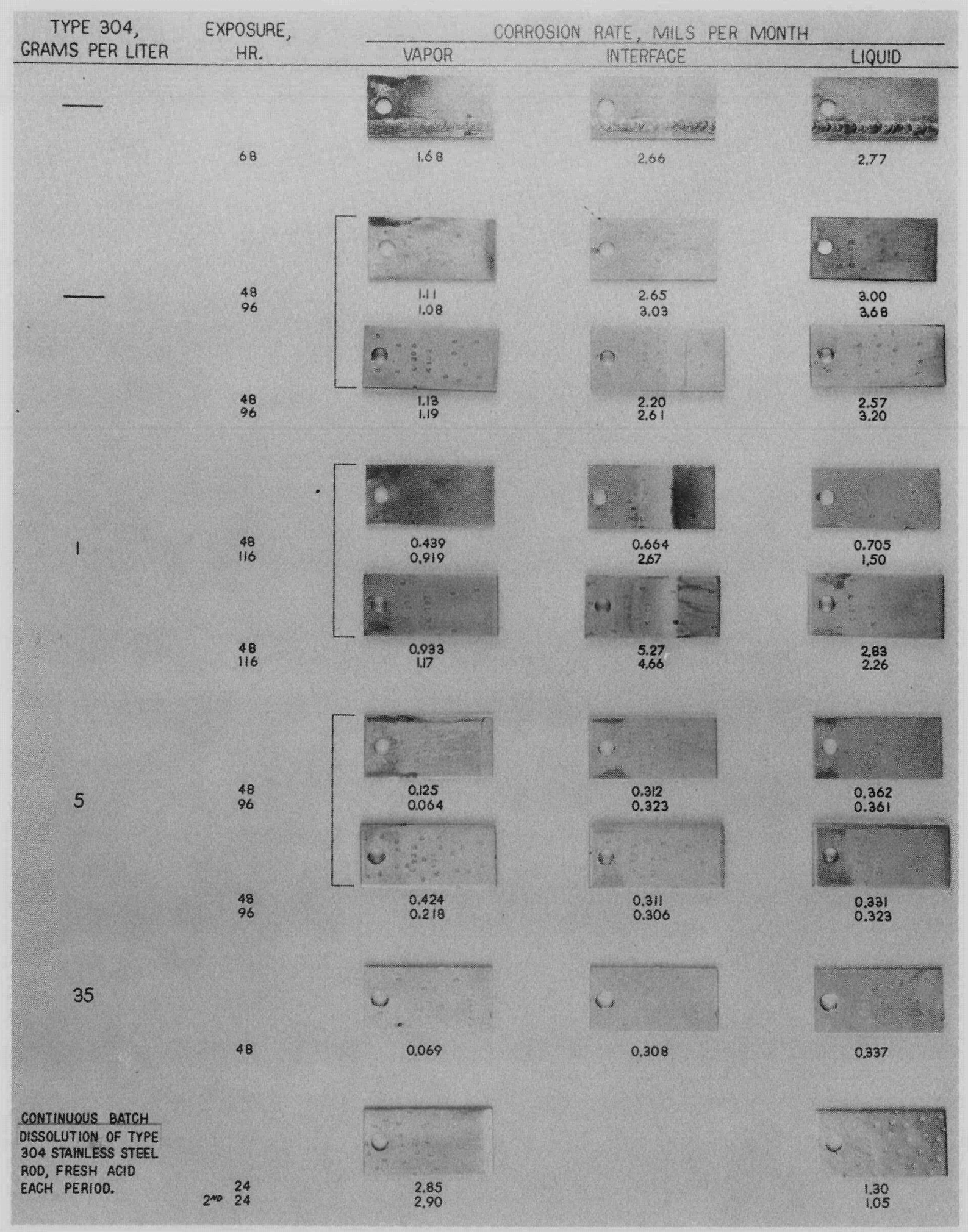

N5 1085

FIGURE 7. EFFECT OF EXPOSURE OF CARPENTER $20 \mathrm{Cb}$ SPECIMENS TO BOILING SULFEX ( $6 \mathrm{M} \mathrm{H}_{2} \mathrm{SO}_{4}$ ) SOLUTIONS CONTAINING CHROMIUM, IRON, AND NICKEL SALTS 
The dissolution was started with $6 \mathrm{M} \mathrm{H}_{2} \mathrm{SO}_{4}$ and was continued until a concentration of about $5 \mathrm{~g}$ per liter of dissolved stainless steel was reached. The acid was then replaced with a new solution. Thus, the inhibition from cations in solution was somewhat reduced. Fifty batches of acid were used giving a total exposure of $124 \mathrm{hr}$. The coupon touching the dissolving steel was uncracked and exhibited a low corrosion rate (about $0.8 \mathrm{mil}$ per month). On the other hand, pieces which were placed in the same container but not in contact with the steel showed cracks, and exhibited corrosion rates over three times greater. Corrosion data are given in Table 6 .

\section{TABLE 6. GALVANIC INFLUENCE OF DISSOLVING STAINLESS STEEL ON THE CORROSION OF CARPENTER $20 \mathrm{Cb}$ IN BOILING SULFEX ( $6 \mathrm{M} \mathrm{H}_{2} \mathrm{SO}_{4}$ ) SOLUTION}

\begin{tabular}{ccccc}
\hline \hline $\begin{array}{c}\text { Number } \\
\text { of } \\
\text { Batches }\end{array}$ & $\begin{array}{c}\text { Exposure, } \\
\mathrm{hr}\end{array}$ & $\begin{array}{c}\text { Specimen } \\
\text { Position }\end{array}$ & $\begin{array}{c}\text { Corrosion Rate, } \\
\text { mils per month }\end{array}$ \\
\hline \multirow{2}{*}{36} & 87 & $\begin{array}{l}\text { Vapor } \\
\text { Liquid }\end{array}$ & $\begin{array}{l}\text { Connected } \\
\text { Insulated }\end{array}$ & $\begin{array}{l}3.3 \\
2.9\end{array}$ \\
50 & \multirow{2}{*}{124} & Vapor & 3.3 & 0.87 \\
& & Liquid & 2.9 & 3.8 \\
& & & & 0.84
\end{tabular}

(a) Dissolution continued until approximately $5 \mathrm{~g}$ per liter of Type 304 stainless steel had dissolved (about $2.5 \mathrm{hr}$ ). Acid was then renewed.

It should be pointed out that, as would be expected, a coupon coupled to the stainless steel in the vapor phase, to simulate such areas in a tank, was not protected and showed cracks and a relatively high corrosion rate.

Thus, it has been shown that both a reduced corrosion rate and protection from cracking will be realized on the submerged portion of a Carpenter $20 \mathrm{Cb}$ vessel during dissolution of fuel pins in contact with that vessel. Additional protection is afforded by the buildup of dissolved stainless steel. However, since the possibility of passivation of the fuel elements requires that they be introduced into boiling, uncontaminated acid, there will always be short periods in which the submerged Carpenter $20 \mathrm{Cb}$ surface is unprotected. In addition, the surface of the vessel in contact with the vapor and splash zone will probably crack at stressed areas in spite of any of the above-mentioned countermeasures. The answer to the control of the cracking problem does not seem to be found in relying on cathodic protection or inhibition from dissolved ions. 
Studies With Ni-o-nel

Cyclic-Exposure Studies

Welded specimens of $\mathrm{Ni}-\mathrm{o}-\mathrm{nel}$ were studied in cyclic exposures similar to those performed with Carpenter $20 \mathrm{Cb}$. A total of ten periods was completed with inspection of the specimens after $1,2,5$, and 10 periods. The data are presented in Table 7 and the corrosion rates for liquid-and vapor-phase specimens are plotted in Figure 8.

The general trend of the corrosion rates approximated that which was observed with Carpenter $20 \mathrm{Cb}$, i.e., rates of the same order of magnitude, and slightly lower rates measured for specimens which were cycled as compared with rates calculated for two specimens exposed independently to each phase of the cycle. The corrosion rates measured for the submerged specimens were highest. Generally, the rates were decreasing with continued exposure.

By the completion of five periods, an intergranular attack had become apparent in the heat-affected areas of the specimens which had been exposed to Thorex solutions. Five additional periods brought this attack to a point where definite "sugaring" of the surface could be seen with the eye. This attack was more severe on specimens exposed to the Initial Thorex solution, probably because of the higher nitric acid concentration and the lack of thorium to provide inhibition.

Sectioning of one of these specimens revealed carbide precipitation in the grain boundaries of the heat-affected areas. Correspondence with the producers of Ni-o-nel revealed that an extra-low-carbon grade of Ni-o-nel is not made. However, experience has shown that titanium is an effective stabilizing agent against carbide precipitation if a titanium-to-carbon ratio of 20 or greater is maintained. The ratio for the material used in the cyclic studies was only 15.5 .

A new supply of Ni-o-nel was used for a second series of cyclic studies. The titanium-to-carbon ratio of this material was 27.0. Coupons were fashioned from material welded under field-service conditions. The edges were machined, the weld bead was left intact, and the surfaces were cleaned by pickling with Initial Thorex solution. The data for these studies appear in Table 8 and are plotted in Figure 9.

Intergranular attack was slight in the heat-affected areas of specimens exposed to Thorex solutions. However, the beginning of a knife-line-type of attack immediately adjacent to the weld bead appeared on submerged specimens. After eight periods, the vapor - and liquid-phase specimens were removed for the purpose of studying various heat treatments aimed at alleviating the intergranular and knife-line attacks. The interface specimens were continued for a total of 16 periods. Intergranular attack became noticeable on these specimens, especially on the portions submerged in Initial Thorex solutions, but only a faint hint of incipient knife-line attack appeared. Perhaps these specimens, which were twice as large as the vapor- or liquid-phase specimens, may have had different cooling characteristics upon welding. 
TABLE 7. CORROSION OF INCOMPLETELY STABILIZED ${ }^{(a)}$ WELDED NI-O-NEL DURING CYCLIC STUDIES IN BOILING SULFEX-THOREX SOLUTIONS

\begin{tabular}{|c|c|c|c|c|c|c|c|c|c|c|c|c|c|}
\hline \multirow[b]{4}{*}{ Periods } & \multirow[b]{4}{*}{$\begin{array}{c}\text { Specimen } \\
\text { Position }\end{array}$} & \multicolumn{12}{|c|}{ Corrosion Rate, mils per month } \\
\hline & & \multicolumn{6}{|c|}{ System I } & \multicolumn{6}{|c|}{ System II } \\
\hline & & \multicolumn{3}{|c|}{ Not Cycled } & \multicolumn{3}{|c|}{ Cycled (A to $B)$} & \multicolumn{3}{|c|}{ Not Cycled } & \multicolumn{3}{|c|}{ Cycled (C to D) } \\
\hline & & $\begin{array}{c}\frac{\mathrm{A}}{\left(6 \mathrm{M} \mathrm{H}_{2} \mathrm{SO}_{4},\right.} \\
3 \mathrm{Hr})\end{array}$ & $\begin{array}{c}\text { B } \\
\text { (Final Thorex, } \\
5 \mathrm{Hr})^{(\mathrm{b})}\end{array}$ & $\begin{array}{l}\text { Weighted } \\
\text { Value for } \\
A+B(c)\end{array}$ & $\begin{array}{c}\text { First } \\
\text { Set }\end{array}$ & $\begin{array}{c}\text { Duplicate } \\
\text { Set }\end{array}$ & Average & $\begin{array}{c}\mathrm{C} \\
\left(4 \mathrm{M} \mathrm{H}_{2} \mathrm{SO}_{4},\right. \\
5 \mathrm{Hr})\end{array}$ & $\begin{array}{c}\text { D } \\
\begin{array}{c}\text { (Initial Thorex, } \\
5 \mathrm{Hr})^{(b)}\end{array}\end{array}$ & $\begin{array}{l}\text { Weighted } \\
\text { Value for } \\
C+D\end{array}$ & $\begin{array}{l}\text { First } \\
\text { Set }\end{array}$ & $\begin{array}{l}\text { Duplicate } \\
\text { Set }\end{array}$ & Average \\
\hline \multirow[t]{3}{*}{1} & Vapor & 0.81 & 1.7 & 1.4 & 1.2 & 1.0 & 1.1 & 1.0 & 3.0 & 2.2 & 3.0 & 2.2 & 2.6 \\
\hline & Interface & 5.6 & 1.7 & 3.2 & 2.6 & 2.9 & 2.7 & 3.1 & 5.2 & 4.4 & 4.0 & 4.0 & 4.0 \\
\hline & Liquid & 7.5 & 2.1 & 4.1 & 3.5 & 3.6 & 3.6 & 5.3 & 4.9 & 5.0 & 4.3 & 4.6 & 4.4 \\
\hline \multirow[t]{3}{*}{2} & Vapor & 0.81 & 1.2 & 1.1 & 0.87 & 0.92 & 0.89 & 0.79 & 2.7 & 2.0 & 2.2 & 1.9 & 2.1 \\
\hline & Interface & 4.1 & 1.4 & 2.5 & 2.1 & 2.3 & 2.2 & 3.1 & 4.5 & 4.0 & 3.6 & 3.7 & 3.7 \\
\hline & Liquid & 5.9 & 1.6 & 3.2 & 3.0 & 3.1 & 3.1 & 4.9 & 4.1 & 4.4 & 3.8 & 3.8 & 3.8 \\
\hline \multirow[t]{3}{*}{5} & Vapor & 0.96 & 0.94 & 0.95 & 0.69 & 0.65 & 0.67 & 0.78 & 2.5 & 1.9 & 1.9 & 1.8 & 1.8 \\
\hline & Interface & 3.6 & 1.2 & 2.1 & 2.0 & 2.0 & 2.0 & 5.3 & 4.0 & 4.5 & 2.7 & 2.8 & 2.7 \\
\hline & Liquid & 4.4 & 1.3 & 2.5 & 2.3 & 2.3 & 2.3 & 10. & 3.6 & 6.0 & 2.7 & 2.7 & 2.7 \\
\hline \multirow[t]{3}{*}{10} & Vapor & 0.76 & 0.82 & 0.79 & 0.56 & 0.53 & 0.55 & 0.69 & 2.6 & 1.9 & 1.8 & 1.9 & 1.8 \\
\hline & Interface & 3.5 & 1.2 & 2.1 & 1.8 & 1.8 & 1.8 & 4.1 & 3.4 & 3.6 & 2.1 & 2.1 & 2.1 \\
\hline & Liquid & 4.1 & 1.2 & 2.3 & 2.1 & 2.1 & 2.1 & 6.3 & 2.9 & 4.2 & 2.1 & 2.0 & 2.0 \\
\hline
\end{tabular}

(a) Ni-o-nel with titanium-to-carbon ratio of 15.5 .

(b) Solution compositions:

Initial Thorex $13.0 \mathrm{M} \mathrm{HNO}_{3}, 0.050 \mathrm{M} \mathrm{F}^{-}, 0.20 \mathrm{M} \mathrm{Al}\left(\mathrm{NO}_{3}\right)_{3}$

Final Thorex $8.5 \mathrm{M} \mathrm{HNO}_{3}, 0.050 \mathrm{M} \mathrm{F}^{-}, 1.0 \mathrm{M} \mathrm{Th}\left(\mathrm{NO}_{3}\right)_{4}, 0.20 \mathrm{M} \mathrm{Al}\left(\mathrm{NO}_{3}\right)_{3}$

(c) The weighted values are calculated as follows (see first line of data):

$\frac{(3 \times 0.81)+(5 \times 1.7)}{8}=1.4$ mils per month. 

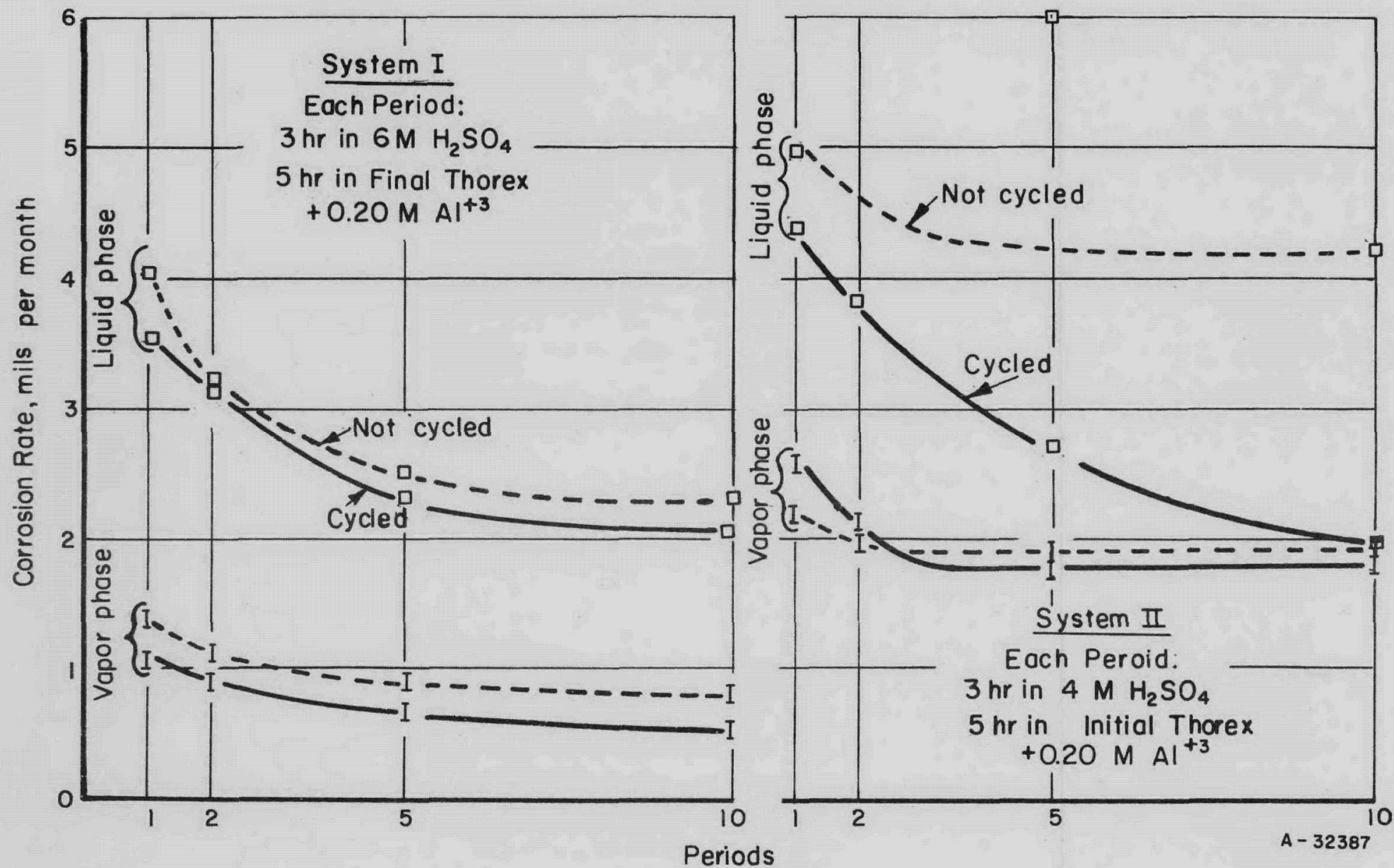

FIGURE 8. CORROSION OF INCOMPLETELY STABILIZED WELDED NI-O-NEL DURING CYCLIC STUDIES IN BOILING SULFEX-THOREX SOLUTIONS 
TABLE 8. CORROSION OF STABILIZED(a) WELDED NI-O-NEL DURING CYCLIC STUDIES IN BOILING SULFEX-THOREX SOLUTIONS

\begin{tabular}{|c|c|c|c|c|c|c|c|c|c|c|c|c|c|}
\hline \multirow[b]{4}{*}{ Periods } & \multirow[b]{4}{*}{$\begin{array}{l}\text { Specimen } \\
\text { Position } \\
\end{array}$} & \multicolumn{12}{|c|}{ Corrosion Rate, mils per month } \\
\hline & & \multicolumn{6}{|c|}{ System I } & \multicolumn{6}{|c|}{ System II } \\
\hline & & \multicolumn{3}{|c|}{ Not Cycled } & \multicolumn{3}{|c|}{ Cycled (A to B) } & \multicolumn{3}{|c|}{ Not Cycled } & \multicolumn{3}{|c|}{ Cycled (C to D) } \\
\hline & & $\begin{array}{c}\mathrm{A} \\
\left(6 \mathrm{M} \mathrm{H}_{2} \mathrm{SO}_{4},\right. \\
3 \mathrm{Hr})\end{array}$ & $\begin{array}{c}\text { B } \\
(\text { Final Thorex, } \\
5 \mathrm{Hr})^{(\mathrm{b})} \\
\end{array}$ & $\begin{array}{l}\text { Weighted } \\
\text { Value } f \circ f_{(c)} \\
A+B\end{array}$ & $\begin{array}{c}\text { First } \\
\text { Set }\end{array}$ & $\begin{array}{c}\text { Duplicate } \\
\text { Set }\end{array}$ & Average & $\begin{array}{c}\mathrm{C} \\
\left(4 \mathrm{M} \mathrm{H}_{2} \mathrm{SO}_{4},\right. \\
3 \mathrm{Hr}) \\
\end{array}$ & $\begin{array}{c}\mathrm{D} \\
\text { (Initial Thorex, } \\
5 \mathrm{Hr} \text { ) } \\
\end{array}$ & $\begin{array}{c}\text { Weighted } \\
\text { Value for } \\
\text { C + D }\end{array}$ & $\begin{array}{l}\text { First } \\
\text { Set }\end{array}$ & $\begin{array}{l}\text { Duplicate } \\
\text { Set }\end{array}$ & Average \\
\hline \multirow[t]{3}{*}{2} & Vapor & 1.1 & 0.75 & 0.88 & 0.80 & 0.55 & 0.68 & 1.7 & 1.9 & 1.8 & 2.0 & 1.8 & 1.9 \\
\hline & Interface & 5.1 & 0.83 & 2.4 & 2.1 & 2.5 & 2.3 & 6.8 & 3.4 & 4.7 & 3.7 & 3.7 & 3.7 \\
\hline & Liquid & 5.5 & 1.1 & 2.7 & 2.5 & 2.5 & 2.5 & 6.0 & 2.9 & 4.0 & 3.2 & 3.8 & 3.5 \\
\hline \multirow[t]{3}{*}{5} & Vapor & 0.61 & 0.77 & 0.71 & 0.87 & 0.41 & 0.64 & 0.76 & 1.8 & 1.4 & 1.4 & 1.4 & 1.4 \\
\hline & Interface & 3.2 & 0.73 & 1.7 & 1.3 & 1.6 & 1.4 & 5.8 & 2.5 & 3.8 & 2.0 & 2.0 & 2.0 \\
\hline & Liquid & 8.8 & 0.97 & 3.9 & 1.6 & 1.6 & 1.6 & 5.6 & 2.4 & 3.6 & 2.0 & 2.2 & 21 \\
\hline \multirow{3}{*}{8} & Yарот & 0.47 & 0.64 & 0.58 & 0.43 & 0.35 & 0.39 & 0.59 & 1.7 & 1.3 & 1.2 & 1.2 & 1.2 \\
\hline & Interface & 3.0 & 0.66 & 1.5 & 1.3 & 1.4 & 1.3 & 4.5 & 2.1 & 3.0 & 1.9 & 1.8 & 1.9 \\
\hline & Liquid & 8.3 & 0.79 & 3.6 & 1.6 & 1.6 & 1.6 & 4.4 & 2.1 & 2.9 & 1.9 & 1.9 & 1.9 \\
\hline 10 & Interface & 2.3 & 0.61 & 1.3 & 1.0 & 1.2 & 1.1 & 3.6 & 2.0 & 2.6 & 1.6 & 1.6 & 1.6 \\
\hline 15 & Interface & 2.2 & 0.57 & 1.2 & 1.0 & 1.1 & 1.0 & 2.8 & 1.9 & 2.2 & 1.6 & 1.5 & 1.6 \\
\hline 16 & Interface & 2.7 & 0.55 & 1.3 & 0.96 & 1.0 & 0.99 & 2.7 & 1.8 & 2.2 & 1.5 & 1.6 & 1.6 \\
\hline
\end{tabular}

(a) New supply of Ni-o-nel with a titanium-to-carbon ratio of 27.0 .

(b) Solution compositions:

Initial Thorex $\left.13.0 \mathrm{M} \mathrm{HNO}_{3}, 0.050 \mathrm{M} \mathrm{F}^{-}, 0.20 \mathrm{M} \mathrm{Al}\left(\mathrm{NO}_{3}\right)_{3}, 20 \mathrm{M} \mathrm{Al}^{2} \mathrm{NO}_{3}\right)_{3}$.

(c) The weighted values are calculated as follows (see first line of data):

$$
\frac{(3 \times 1.1)+(5 \times 0.75)}{8}=0.88 \text { mil per month. }
$$



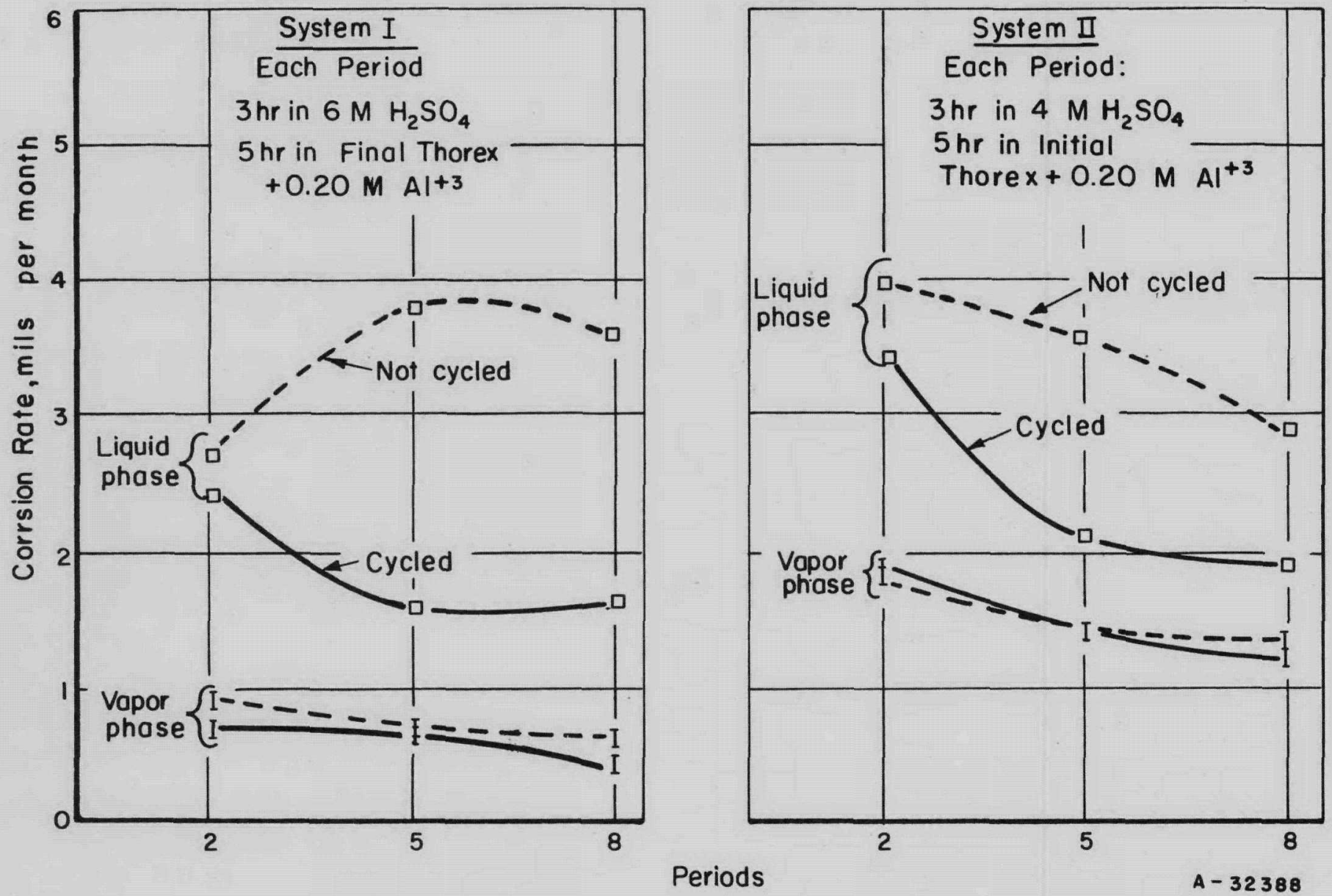

FIGURE 9. CORROSION OF STABILIZED WELDED NI-O-NEL DURING CYCLIC STUDIES IN BOILING SULFEX-THOREX SOLUTIONS 
Effects of Heat Treatments on the Intergranular Corrosion of $\mathrm{Ni-0-ne1}$

In an attempt to lessen the susceptibility of Ni-o-nel to intergranular attack, a wide range of heat treatments was studied. Annealing temperatures from 1650 to $1950 \mathrm{~F}$ were used for various durations. Annealed specimens were quenched both in air and in water. Heat treatments both before and after welding were investigated as well as different welding procedures. Evaluations were carried out by exposing the specimens to the liquid phase of boiling Initial Thorex solutions.

The descriptions and results of these studies are given in detail in Appendix B. Briefly, the data indicate that the best welding procedure is the shielded-arc process using strips cut from the parent metal for electrodes. No heat treatment completely eliminated intergranular attack over long exposure, but the most beneficial treatment found would be performed after welding using an anneal at $1850 \mathrm{~F}$ followed by a water quench. The length of anneal is not critical $(0.5$ to $2 \mathrm{hr})$. If water quenching is not feasible, annealing at $1950 \mathrm{~F}$ and quenching in air, as rapidly as possible, will give nearly as good results.

\section{Effectiveness of Aluminum} for Corrosion Control

Present flowsheet conditions will not permit the use of $0.2 \mathrm{M} \mathrm{Al}^{+3}$ additions without complications arising in the Thorex process. Three intermediate additions of 0.04 , 0.09 , and $0.15 \mathrm{M}$ were scouted to determine the minimum $\mathrm{Al}^{+3}$ addition necessary to control corrosion of $\mathrm{Ni}-\mathrm{o}-\mathrm{nel}$. Intergranular attack was observed after $24 \mathrm{hr}$ with $0.04 \mathrm{M}, 49 \mathrm{hr}$ with $0.09 \mathrm{M}$, and after $72 \mathrm{hr}$ with $0.15 \mathrm{M} \mathrm{Al+3}$ additions on all specimens. The results of these studies are shown in Table 9. A plot of the corrosion rates for the liquid-phase specimens of these and former studies is shown in Figure 10. At least $0.1 \mathrm{M} \mathrm{AI}^{+3}$ appears necessary to control corrosion under these conditions. Ultimately, the minimum $\mathrm{Al}^{+3}$ addition to sufficiently mitigate corrosion must be chosen after taking account of the duration in which the conditions of the Initial Thorex solutions will prevail in the dissolver.

\section{Effects of Ions in the Decladding Solution}

Several experiments were conducted to determine whether an aggressive attack of $\mathrm{Ni}-\mathrm{o}-\mathrm{nel}$ would occur from Sulfex solutions containing appreciable quantities of dissolved stainless steel.

This point was evaluated on two occasions. First, as-received specimens of unstabilized Ni-o-nel were exposed for three 24-hr periods to boiling $6 \mathrm{M} \mathrm{H}_{2} \mathrm{SO}_{4}$, both uncontaminated and with additions of $\mathrm{Cr}^{+6}, \mathrm{Fe}^{++}, \mathrm{Ni}^{++}$salts equivalent to 5 and $35 \mathrm{~g}$ per liter of dissolved Type 304 stainless steel. The results of these evaluations, as shown in Table 10 and Figure 11, indicate that dissolution products inhibited the corrosion of $\mathrm{Ni}-\mathrm{o}-\mathrm{nel}$ and that the corrosion rates did not increase with continued exposure; at least during the extent of these studies. No cracking or other localized attack was observed. 


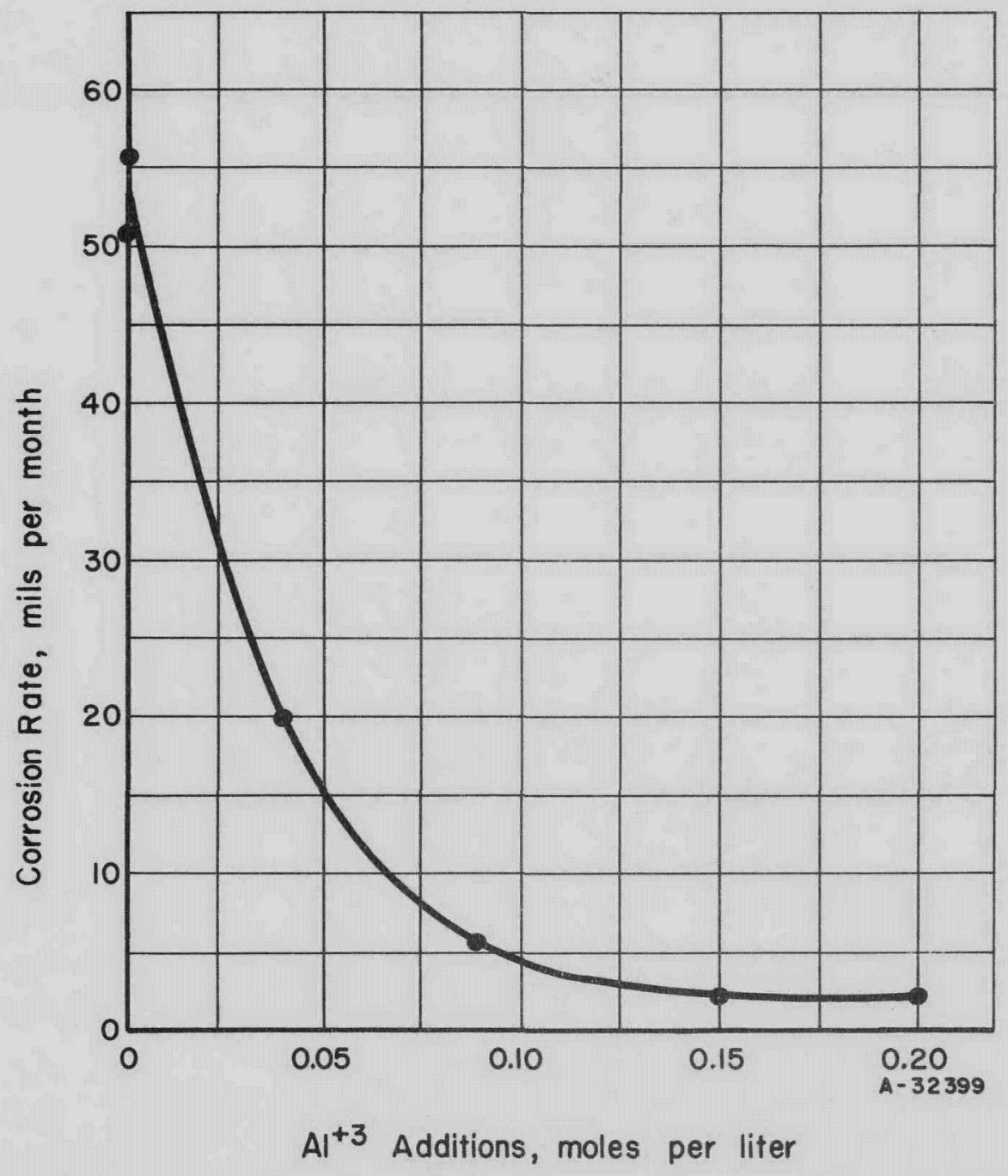

FIGURE 10. CORROSION RATES OF NI-O-NEL IN BOILING INITIAL THOREX SOLUTIONS WITH VARIOUS ALUMINUM ADDITIONS

Unwelded, liquid-phase specimens were exposed $24 \mathrm{hr}$. Initial Thorex Composition: $13.0 \mathrm{M} \mathrm{HNO}_{3}, 0.05 \mathrm{M} \mathrm{F}^{-}$. 
TABLE 9. RESULTS OF SCOUTING EXPERIMENTS WITH UNWELDED STABILIZED NI-O-NEL SPECIMENS IN BOILING INITIAL THOREX SOLUTIONS(a) CONTAINING VARIOUS A1 ${ }^{+3}$ ADDITIONS

\begin{tabular}{lllll}
\hline \hline \multirow{2}{*}{$01^{+3}$} & $\begin{array}{l}\text { Specimen } \\
\text { Position }\end{array}$ & \multicolumn{3}{c}{ Corrosion Rate, mils per month } \\
\cline { 3 - 4 } $0.04 \mathrm{M}$ & & $24 \mathrm{Hr}$ & $48 \mathrm{Hr}$ & $72 \mathrm{Hr}$ \\
& Vapor & 20 & 22 & - \\
& Interface & 20 & 22 & - \\
& Liquid & 20 & 22 & 6.1 \\
$0.09 \mathrm{M}$ & Vapor & 5.7 & 5.9 & 5.7 \\
& Interface & 5.3 & 5.4 & 5.8 \\
& Liquid & 5.4 & 5.5 & 2.4 \\
$0.15 \mathrm{M}$ & Vapor & 2.5 & 2.4 & 2.4 \\
& Interface & 2.5 & 2.4 & 2.4 \\
& Liquid & 2.6 & 2.4 & \\
\hline \hline
\end{tabular}

(a) Fresh solutions used for each 24 -hr period.

TABLE 10. CORROSION OF UNSTABILIZED NI-O-NEL EXPOSED TO BOILING CONTAMINATED SULFEX $\left(6 \mathrm{M} \mathrm{H}_{2} \mathrm{SO}_{4}\right)$ SOLUTIONS

\begin{tabular}{|c|c|c|c|c|}
\hline \multirow{2}{*}{$\begin{array}{c}\text { Equivalent Type } 304(\mathrm{a}) \text {, } \\
\text { g per liter }\end{array}$} & \multirow{2}{*}{$\begin{array}{l}\text { Specimen } \\
\text { Position }\end{array}$} & \multicolumn{3}{|c|}{ Corrosion Rate, mils per month } \\
\hline & & $24 \mathrm{Hr}$ & $48 \mathrm{Hr}$ & $72 \mathrm{Hr}$ \\
\hline \multirow[t]{3}{*}{0.0} & Vapor & 2.3 & 1.7 & 1.4 \\
\hline & Interface & 7.2 & 6.3 & 4.9 \\
\hline & Liquid & 7.3 & 5.9 & 4.7 \\
\hline \multirow[t]{3}{*}{5.0} & Vapor & 0.89 & 0.72 & 0.73 \\
\hline & Interface & 0.35 & 0.36 & 0.32 \\
\hline & Liquid & 0.42 & 0.42 & 0.38 \\
\hline \multirow[t]{3}{*}{35.0} & Vapor & 0.16 & 0.15 & 0.12 \\
\hline & Interface & 0.36 & 0.38 & 0.34 \\
\hline & Liquid & 0.36 & 0.36 & 0.33 \\
\hline
\end{tabular}

(a) Added as $\mathrm{Cr}^{+6}, \mathrm{Fe}^{++}$, and $\mathrm{Ni}^{++}$salts. 
TABLE 11. CORROSION OF STABILIZED NI-O-NEL EXPOSED TO BOILING SULFEX $\left(3.5 \mathrm{M} \mathrm{H}_{2} \mathrm{SO}_{4}\right)$ SOLUTIONS CONTAINING $50 \mathrm{G}$ PER LITER DISSOLVED TYPE 304 STAINLESS STEEL

\begin{tabular}{|c|c|c|c|c|c|c|c|c|c|}
\hline \multirow{2}{*}{$\begin{array}{l}\text { Specimen } \\
\text { Type }\end{array}$} & \multirow{2}{*}{$\begin{array}{l}\text { Stainless } \\
\text { Addition }\end{array}$} & \multirow{2}{*}{$\begin{array}{l}\text { Specimen } \\
\text { Position }\end{array}$} & \multicolumn{7}{|c|}{$\begin{array}{l}\text { Corrosion Rate, } \\
\text { mils per month }\end{array}$} \\
\hline & & & $24 \mathrm{Hr}$ & $48 \mathrm{Hr}$ & $72 \mathrm{Hr}$ & $144 \mathrm{Hr}$ & $312 \mathrm{Hr}$ & $480 \mathrm{Hr}$ & $648 \mathrm{Hr}$ \\
\hline \multirow[t]{3}{*}{ As received } & \multirow[t]{3}{*}{ Salts(a) } & Vapor & $g(b)$ & 0.02 & 0.01 & 0.00 & 0.01 & 0.01 & 0.01 \\
\hline & & Interface & 0.14 & 0.24 & 0.27 & 0.31 & 0.36 & 0.31 & 0.26 \\
\hline & & Liquid & 0.20 & 0.28 & 0.31 & 0.36 & 0.42 & 0.35 & 0.29 \\
\hline \multirow{3}{*}{$\begin{array}{l}\text { Welded and heat } \\
\text { treated }(c)\end{array}$} & \multirow[t]{3}{*}{ Salts(a) } & Vapor & $\mathrm{g}$ & $\mathrm{g}$ & g & $\mathrm{g}$ & 0.01 & 0.01 & 0.01 \\
\hline & & Interface & 0.01 & 0.28 & 0.23 & 0.30 & 0.35 & 0.36 & 0.36 \\
\hline & & Liquid & 0.10 & 0.24 & 0.30 & 0.33 & 0.41 & 0.43 & 0.42 \\
\hline \multirow[t]{3}{*}{ As received } & \multirow[t]{3}{*}{ By dissolution } & Vapor & 0.59 & 0.59 & 0.62 & 0.39 & 0.34 & 0.29 & 0.29 \\
\hline & & Interface & 2.0 & 1.3 & 1.1 & 1.0 & 0.69 & 0.63 & 0.53 \\
\hline & & Liquid & 1.1 & 0.80 & 0.77 & 0.73 & 0.47 & 0.44 & 0.38 \\
\hline \multirow{3}{*}{$\begin{array}{l}\text { Welded and heat } \\
\text { treated }(c)\end{array}$} & \multirow[t]{3}{*}{ By dissolution } & Vapor & 0.43 & 0.43 & 0.45 & 0.29 & 0.28 & 0.32 & 0.33 \\
\hline & & Interface & 1.4 & 0.98 & 0.87 & 0.90 & 0.60 & 0.53 & 0.43 \\
\hline & & Liquid & 1.0 & 0.69 & 0.65 & 0.60 & 0.40 & 0.40 & 0.36 \\
\hline
\end{tabular}

(a) Added as $\mathrm{CrO}_{3}, \mathrm{FeSO}_{4}$, and $\mathrm{NiSO}_{4}$ in ratio of Type 304 stainless steel.

(b) $\mathrm{g}$ indicates a slight gain in weight.

(c) Heat treated for $0.5 \mathrm{hr}$, air quenched after welding; surface ground prior to exposure. 
On the second occasion, specimens of stabilized Ni-o-nel were exposed to boiling $3.5 \mathrm{M} \mathrm{H}_{2} \mathrm{SO}_{4}$ containing $50 \mathrm{~g}$ per liter of dissolved Type 304 stainless steel. Both as received and welded specimens were exposed. The welded specimens had been heat treated after welding for $0.5 \mathrm{hr}$ at $1850 \mathrm{~F}$ and air quenched. Solutions were made both by dissolving Type 304 stainless steel and by adding $\mathrm{Cr}^{+6}, \mathrm{Fe}^{++}$, and $\mathrm{Ni}^{++}$salts in the appropriate proportions. These studies are summarized in Table 11. The general trends of corrosion rates for liquid-phase as-received specimens are shown in Figure 12.

Neither solution produced high corrosion rates, although, initially, rates were about a magnitude higher in the dissolved-steel solution. After $480 \mathrm{hr}$, both groups approach the same value. General intergranular attack had occurred on the specimens in the salt solution after $312 \mathrm{hr}$, while only very light intergranular attack was noted on the specimens in the solutions containing dissolved steel after the same time. Some grains had fallen from the surface of specimens exposed to the salt solutions, while the welds were only lightly etched. The specimens exposed to the liquid phase of the dis solved-steel solutions were covered with a copper-colored powder. After $648 \mathrm{hr}$, specimens exposed to these solutions had not changed appreciably from the descriptions above.

\section{Galvanic Effects During Decladding}

Galvanic currents will be generated in the dissolver during decladding. To study their effects, welded specimens of $\mathrm{Ni}-\mathrm{o}-\mathrm{nel}$ which had been heat treated for $0.5 \mathrm{hr}$ at $1850 \mathrm{~F}$ and air quenched were exposed to boiling $6 \mathrm{M} \mathrm{H}_{2} \mathrm{SO}_{4}$, both under straight refluxing conditions and refluxing in the presence of dissolving stainless steel. The results of these studies are given in Table 12 and the specimens are shown, following exposure, in Figure 13.

TABLE 12. CORROSION RATES OF WELDED HEAT-TREATED STABILIZED
NI-O-NEL(a) IN BOILING $6 \mathrm{M} \mathrm{H}_{2} \mathrm{SO}_{4}$

\begin{tabular}{|c|c|c|c|c|c|}
\hline $\begin{array}{c}\text { Type of } \\
\text { Exposure }\end{array}$ & $\begin{array}{l}\text { Specimen } \\
\text { Position }\end{array}$ & $\frac{\text { Corrosion Rat }}{48 \mathrm{Hr}}$ & $\frac{\text { te for Duplica }}{50 \mathrm{Hr}}$ & $\frac{\text { ate Specimens, }}{122 \mathrm{Hr}}$ & $\frac{\text { mils per month }}{192 \mathrm{Hr}}$ \\
\hline $\begin{array}{l}\text { Reflux, no } \\
\text { dis solution }\end{array}$ & $\begin{array}{l}\text { Vapor } \\
\text { Liquid }\end{array}$ & $\begin{array}{l}1.0 \text { and } 0.98 \\
2.7 \text { and } 2.7\end{array}$ & $\begin{array}{l}-- \\
--\end{array}$ & $\begin{array}{l}0.84 \text { and } 0.72 \\
2.2 \text { and } 2.3\end{array}$ & $\begin{array}{l}0.87 \text { and } 0.73 \\
2.1 \text { and } 2.1\end{array}$ \\
\hline $\begin{array}{l}\text { Reflux plus } \\
\text { batch dis - } \\
\text { solution(b) }\end{array}$ & $\begin{array}{c}\text { Vapor } \\
\text { Liquid } \\
\text { Liquid-contact }\end{array}$ & $\begin{array}{l}-- \\
-- \\
--\end{array}$ & $\begin{array}{l}2.8 \text { and } 1.9 \\
2.2 \text { and } 2.3 \\
0.57\end{array}$ & $\begin{array}{l}2.3 \text { and } 1.9 \\
2.3 \text { and } 2.5 \\
0.60\end{array}$ & $\begin{array}{l}2.1 \text { and } 1.8 \\
2.2 \text { and } 2.3 \\
0.59\end{array}$ \\
\hline
\end{tabular}

(a) Specimens of stabilized $\mathrm{Ni}$-o-nel (titanium-to-carbon ratio of 27 to 1 ) containing weldments were heat treated at $1850 \mathrm{~F}$ for $0.5 \mathrm{hr}$, air quenched, and machined to give clean, smooth surfaces.

(b) Batch dissolution of Type 304 stainless steel rod was carried out during this exposure. Seventy-seven batches were used for an average time of $2.5 \mathrm{hr}$ per batch. 


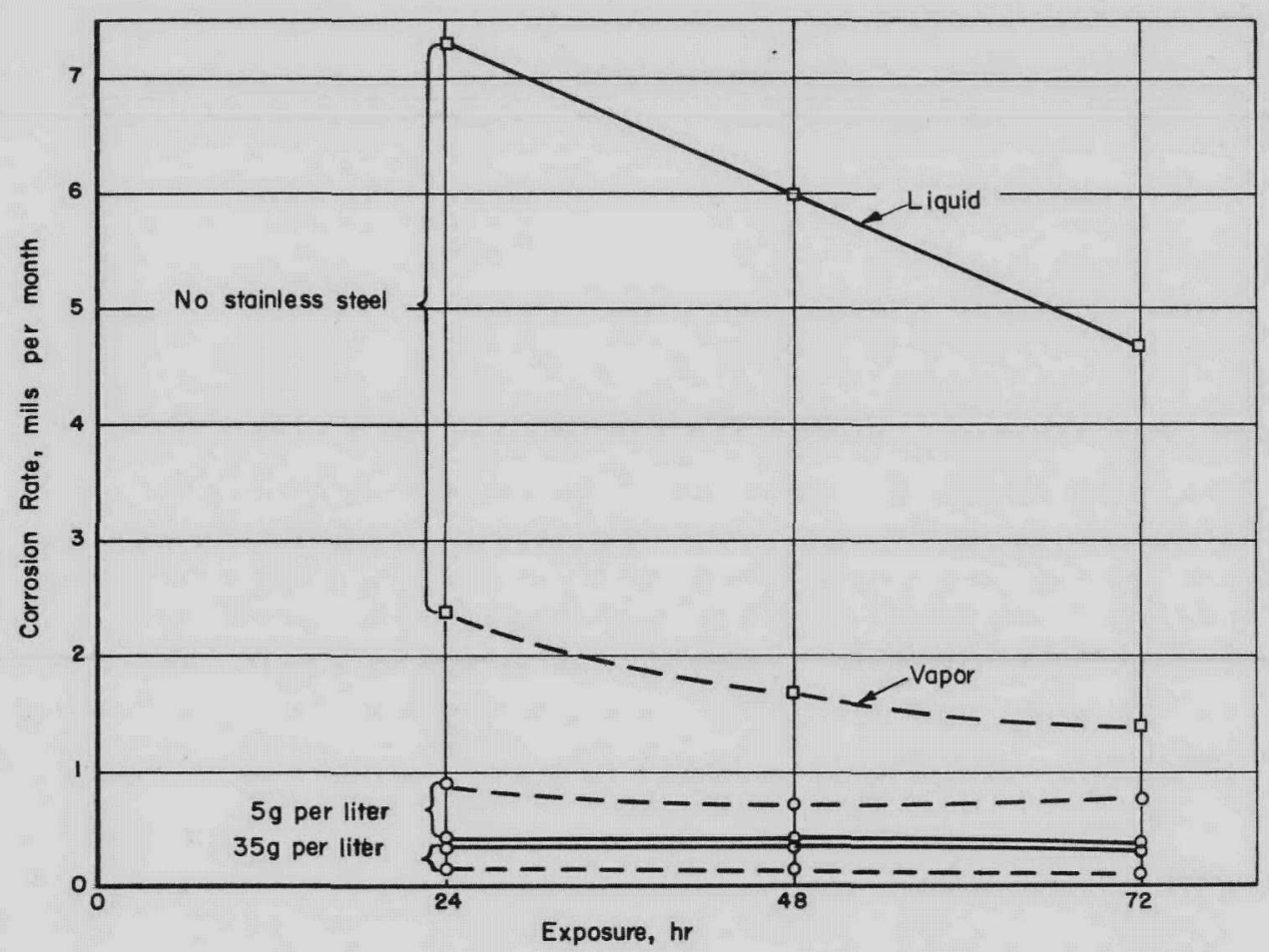

FIGURE 11. CORROSION OF UNSTABILIZED NI-O-NEL BY CONTAMINATED BOILING SULFEX $\left(6 \mathrm{M} \mathrm{H}_{2} \mathrm{SO}_{4}\right)$ SOLUTIONS

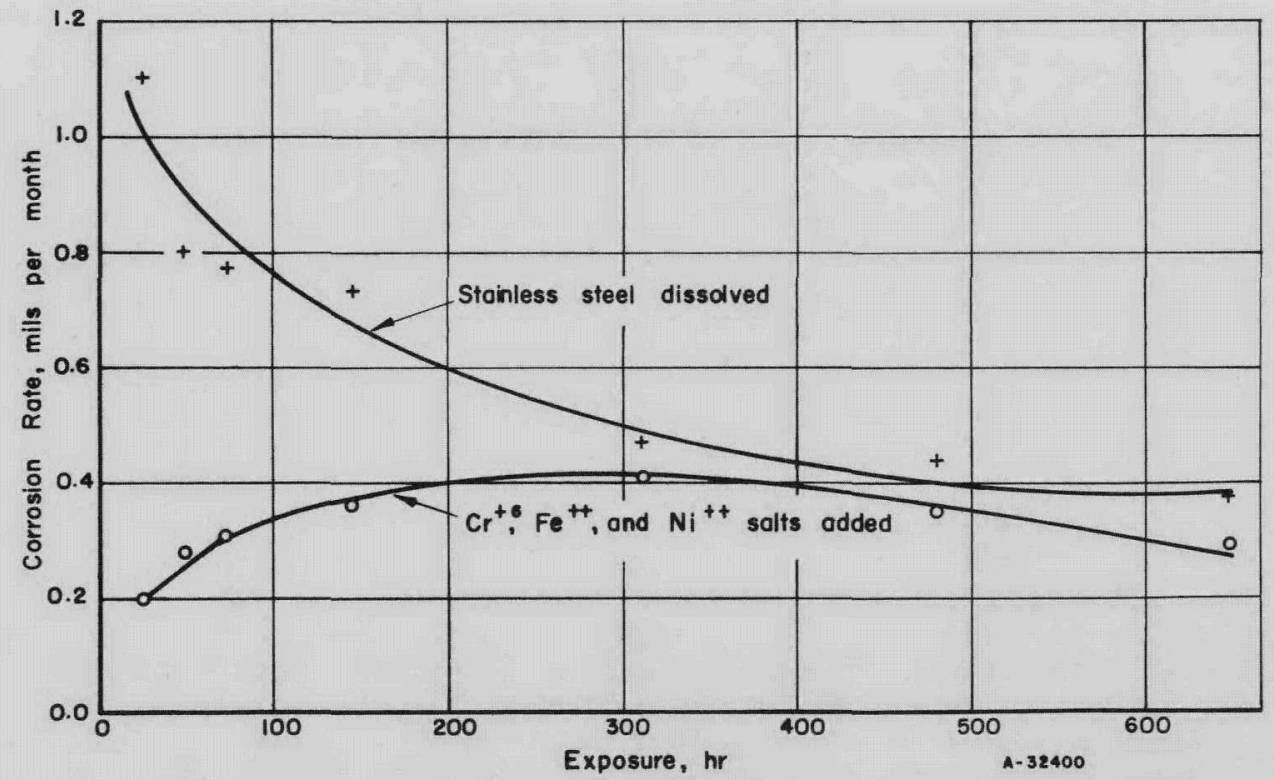

FIGURE 12. CORROSION OF SUBMERGED STABILIZED NI-O-NEL SPECIMENS IN BOILING $3.5 \mathrm{M} \mathrm{H}_{2} \mathrm{SO}_{4}$ CONTAINING $50 \mathrm{~g}$ PER LITER DISSOLVED STAINLESS STEEL 


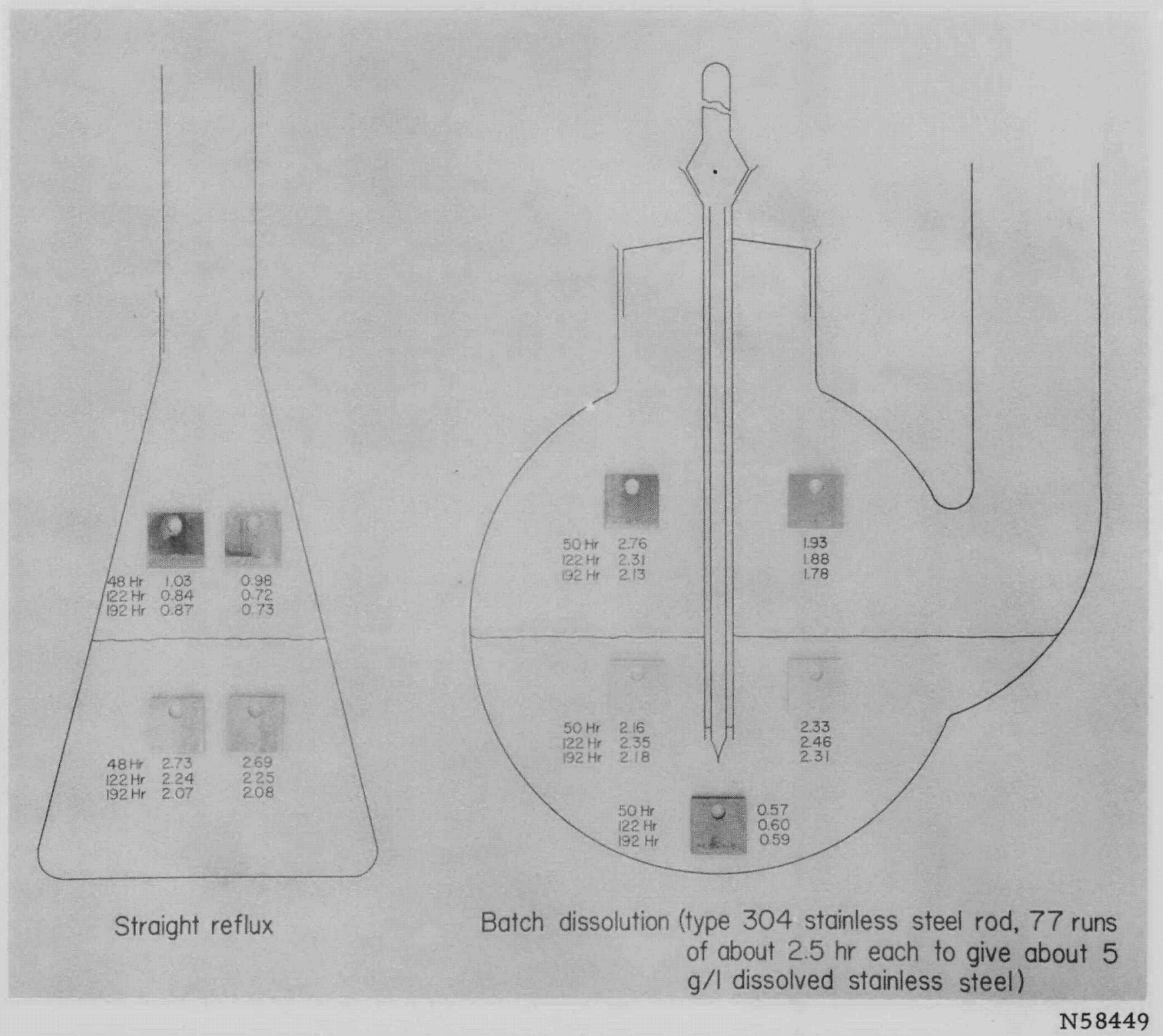

FIGURE 13. EFFECT OF EXPOSURE OF WELDED STABILIZED NI-O-NEL SPECIMENS IN BOILING $6 \mathrm{M} \mathrm{H}_{2} \mathrm{SO}_{4}$ SOLUTIONS ALONE AND IN THE PRESENCE OF DISSOLVING STAINLESS STEEL

Specimens were heat treated $0.5 \mathrm{hr}$ at $1850 \mathrm{~F}$ after welding and air quenched. 
The over-all resistance to sulfuric acid is much better for the heat-treated $\mathrm{Ni}-\mathrm{o}-\mathrm{nel}$ than for the as-welded material (compare with values of $2.3,7.2$, and 7.3 for vapor, interface, and liquid specimens as shown in Table 10). When dissolution occurred, the corrosion rates of the vapor specimens increased two or three times over the values measured during straight refluxing. Attack on the unconnected, submerged specimens was about the same. The submerged specimen in contact with the dissolving stainless steel rod received cathodic protection, as evidenced by about a 75 per cent decrease in the corrosion rate. This specimen was dull in appearance and showed no etching or selective attack. The four other specimens in the same flask were bright, and the surfaces etched to a degree approaching a chemical polish. No evidence of selective attack was seen on these, either.

Bench Dissolution of Fuel Pins

by a Sulfex-Thorex Operation

The final examination of Ni-o-nel as a material of construction for the SulfexThorex process was based on the actual dissolution of Consolidated Edison fuel pins. These pins, in the unirradiated form, were supplied by ORNL. They were approximately $7.4 \mathrm{in}$. long by $0.31 \mathrm{in}$. in diameter. The cladding of each pin was made from roughly $25 \mathrm{~g}$ of Type $304 \mathrm{ELC}$ stainless steel and the core contained $44 \mathrm{~g}$ of $95.5 \mathrm{w} / 0$ $\mathrm{ThO}_{2}-4.5 \mathrm{w} / 0 \mathrm{UO}_{2}$.

A bench-scale dissolver was fabricated from Ni-o-nel, along with two similar ones from Carpenter $20 \mathrm{Cb}$ and Titanium 75A. These are shown in various stages of as sembly in Figure 14. The particular design was chosen to allow the fuel pins to rest horizontally on the bottom and still conserve material.

The flanges visible in Figure 14 on the top of the container and on the bottom of the condenser tube were cut from heavier gage material than the container walls. A Teflon gasket was placed between the two flanges, which were then tightened together with C-clamps, as shown. As also shown in Figure 14, the containers were heated by three strip heaters, controlled by variable transformers, and the condenser tubes were water jacketed.

The Carpenter $20 \mathrm{Cb}$ dissolver was shipped to ORNL in the as-welded condition. Dissolution experiments are planned for this vessel in the future. The dissolutions made in the Titanium 75A dissolver will be described in a later section.

After the Ni-o-nel dissolver was welded together by the shielded-arc method using strips of Ni-o-nel as weld electrodes, the entire bottom assembly was heat treated. The treatment chosen consisted of $1 \mathrm{hr}$ at $1950 \mathrm{~F}$ followed by a rapid quench with an air blast. Scale was removed from the surfaces by sand blasting followed by pickling for $45 \mathrm{~min}$ with boiling $13 \mathrm{M} \mathrm{HNO}_{3}, 0.04 \mathrm{M} \mathrm{F}^{-}$. Two saw cuts were made vertically from the bottom up the central area of the sides. These were closed by welding, using good shielding techniques in one case and poor shielding in the other. Thus, this dissolver presented the opportunity to study the resistance of welds made both before and after heat treating along with sharp bends and crevices. 

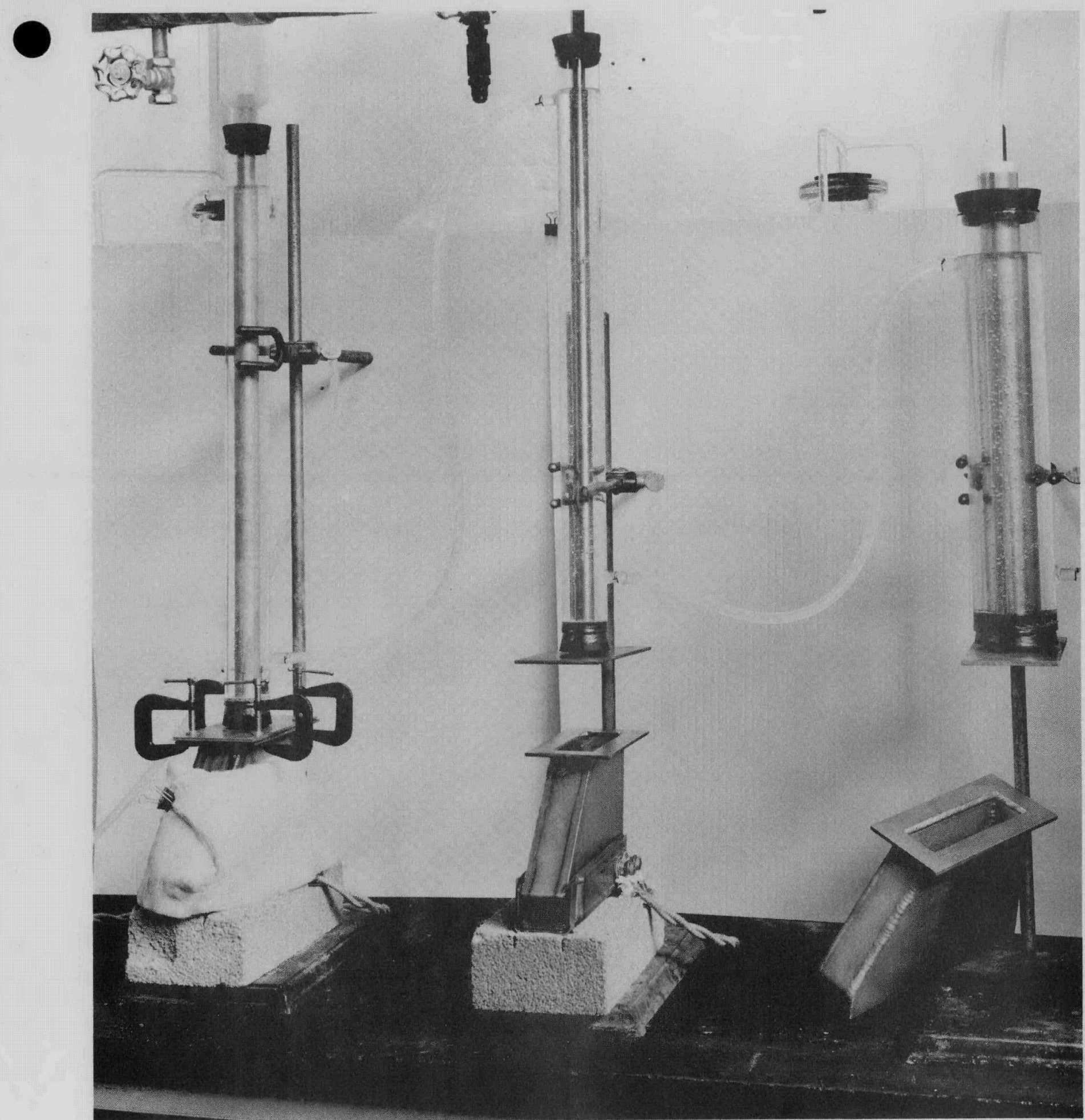

N57611

FIGURE 14. EQUIPMENT FOR BENCH-SCALE DISSOLUTION OF CONSOLIDATED EDISON FUEL PINS

Shown in various stages of assembly are, from the left, Carpenter $20 \mathrm{Cb}$, Titanium, 75A, and Ni-o-nel dissolvers. 
Twenty-five pins were dissolved, one at a time, in this container by a SulfexThorex operation. The solutions remaining from each discrete step were bottled and shipped to ORNL. There they will be analyzed to give information concerning the dissolution process.

The steps of the dissolution as originally followed are shown in Figure 15. Each new pin dissolution was started with the solids remaining from previous dis solutions. On a number of occasions, difficulty was experienced with the fuel pins becoming passive. Some of this trouble was alleviated by altering the operating techniques regarding washing and the initial introduction of the pin into the acid. The details of the various dissolutions are given in Appendix C.

Three Ni-o-nel coupons, heat treated as indicated in Table 13, were placed on the bottom of the container at the beginning of the dissolutions. After several dissolutions it became apparent that appreciable attack was occurring above the liquid line, so two coupons were suspended in the vapor phase. These coupons were removed periodically and weighed so that an estimate of the container corrosion could be obtained. Table 13 shows the corrosion rates calculated from the weight losses for these coupons measured at various times throughout the experiment. After the dissolution of 25 pins ( $285.5 \mathrm{hr}$ under operating conditions) these coupons were sectioned for metallographic examination. Corrosion-rate data based on the sound metal remaining are also shown in Table 13. The metallographically determined rates for the submerged specimens range from 4.5 to about 6 mils per month, and are higher than those based on weight-loss data because surface layers of the specimens were roughened by corrosion and could not be included in the measurement of sound metal.

Both vapor-phase specimens were attacked intergranularly. This explains the large difference between the rates based on sound metal remaining and on weight losses for these specimens. The heat treated vapor-phase specimen with the corrosion rate of 27 mils per month was found upon sectioning to have heavy carbide precipitation at the grain boundaries. Indications are that this specimen never reached the desired annealing temperature but was left with a sensitized structure. Such a structure is known to be susceptible to attack by fluoride-containing nitric acid solutions. It provides a good argument for the necessity of solution annealing $\mathrm{Ni-o-nel} \mathrm{to} \mathrm{minimize}$ intergranular attack by boiling Thorex solutions.

The container was weighed several times following pin dissolutions. The over-all corrosion rate calculated on the basis of the weight loss and the exposed area of the container was 2.3 mils per month after the dissolution of 13 pins. At the end, this rate was about 2.9 mils per month, and calculated over the interval from the thirteenth to twenty-fifth pin it was 3.6 mils per month. This indicates some acceleration of corrosion during the later stages of the dissolution experiment, and this probably resulted from the heavy localized attack which occurred around the unannealed weldments. The solutions remaining after the core-dissolution steps in this dissolver were always colored a deep greenish blue by corrosion products.

After the dissolution of 25 pins, the container was sawed in two and examined. The inside surface of one half is shown in Figure 16. The bands of localized attack surrounding the centrally located weldments are clearly visible. These are shown at $2 \mathrm{X}$ in Figure 17. These are the weldments that were made after heat treatment of the container. Similar attack is not visible around the weldments which were given a solution anneal. 


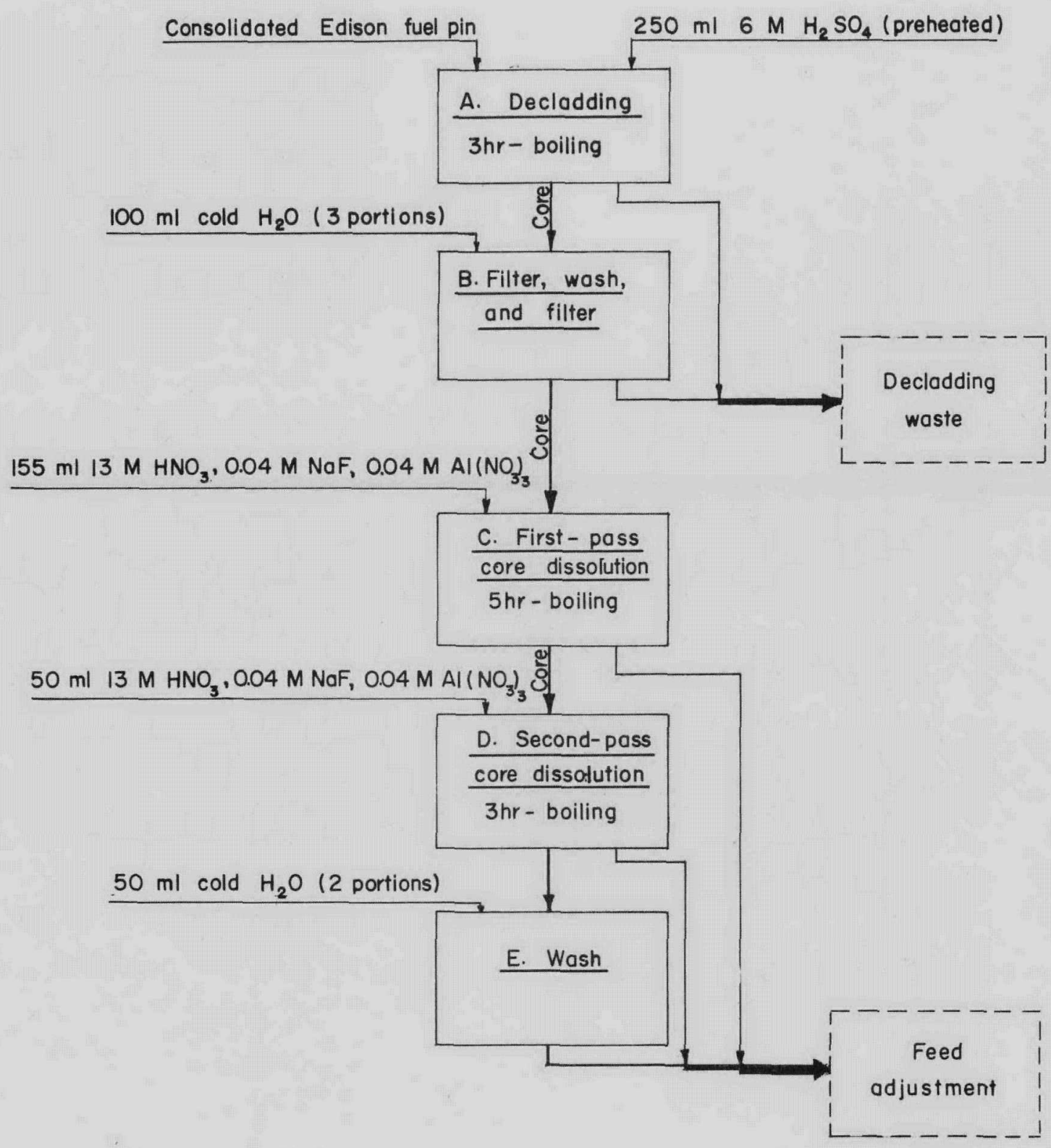

A-32389

FIGURE 15. SCHEDULE FOR SULFEX-THOREX BENCH DISSOLUTION OF CONSOLIDATED EDISON FUEL PINS

Based on information obtained from L. M. Ferris of the Chemical Technology Division of ORNL. 
TABLE 13. RESULTS OF EXPOSURE OF NI-O-NEL CORROSION SPECIMENS IN THE SULFEX-THOREX DISSOLVER

\begin{tabular}{|c|c|c|c|c|c|c|c|c|c|c|c|}
\hline \multirow[b]{3}{*}{ Specimen } & \multirow{3}{*}{$\begin{array}{l}\text { Specimen } \\
\text { Condition }\end{array}$} & \multirow{3}{*}{$\begin{array}{l}\text { Area, } \\
\text { in. }\end{array}$} & \multicolumn{9}{|c|}{ Specimen Corrosion Rate Determined After Dissolution of Number of Pins Shown, mils per month } \\
\hline & & & \multicolumn{8}{|c|}{ By Weight-Loss Measurements } & \multirow{2}{*}{$\begin{array}{c}\text { By Metallography } \\
\text { After } 25 \text { Pins }\end{array}$} \\
\hline & & & 1 & 7 & 9 & 10 & 15 & 17 & 20 & 25 & \\
\hline & & & \multicolumn{8}{|c|}{ Specimens Exposed in Liquid for Time Shown } & \\
\hline A & $\begin{array}{l}\text { Unwelded, heat } \\
\text { treated(a) }\end{array}$ & 4.8 & $\frac{8 \mathrm{Hr}}{3.1}$ & $\frac{79.5 \mathrm{Hr}}{1.9}$ & $\frac{101.5 \mathrm{Hr}}{1.8}$ & $\frac{120.5 \mathrm{Hr}}{1.9}$ & $\frac{175.5 \mathrm{Hr}}{1.7}$ & $\frac{197.5 \mathrm{Hr}}{1.7}$ & $\frac{230.5 \mathrm{Hr}}{1.6}$ & $\frac{285.5 \mathrm{Hr}}{1.5}$ & $\frac{285.5 \mathrm{Hr}}{5.8}$ \\
\hline B & $\begin{array}{l}\text { Heat treated }(a) \\
\text { after welding }\end{array}$ & 4.4 & 4.7 & 2.8 & 2.6 & 2.7 & 2,4 & 2.2 & 2,2 & 2.1 & 4.5 \\
\hline C & $\begin{array}{l}\text { Heat treated(a) } \\
\text { before welding }\end{array}$ & 4.8 & 3.8 & 2,1 & 1.9 & 2.1 & 1.8 & 1.7 & 1.6 & 1.5 & 4.9 \\
\hline & & & & \multicolumn{8}{|c|}{ Specimens Exposed in Vapor for Time Shown ${ }^{(b)}$} \\
\hline D & $\begin{array}{l}\text { Heat treated }(c) \\
\text { after welding }\end{array}$ & 1.2 & -- & $\frac{11 \mathrm{Hr}}{2.5}$ & $\frac{36 \mathrm{Hr}}{2.3}$ & $\frac{55 \mathrm{Hr}}{3.4}$ & $\frac{110 \mathrm{Hr}}{4.2}$ & $\frac{132 \mathrm{Hr}}{4.5}$ & $\frac{165 \mathrm{Hr}}{5.1}$ & $\frac{220 \mathrm{Hr}}{6.1}$ & $\frac{220 \mathrm{Hr}}{27}$ \\
\hline E & As received & 1.4 & -- & 2.0 & 1.4 & 1.7 & 1.5 & 1.4 & 1.4 & 1.4 & 8.5 \\
\hline
\end{tabular}

(a) Heat treated at $1950 \mathrm{~F}$ for $2 \mathrm{hr}$, air quenched, sandblasted, and then pickled.

(b) Vapor specimens were put in after the sixth pin.

(c) Nominally heat treated at $1850 \mathrm{~F}$ for $1 / 2 \mathrm{hr}$, air quenched, and then surface ground. Metallographic examination later showed that carbides had not been retained in solution. 


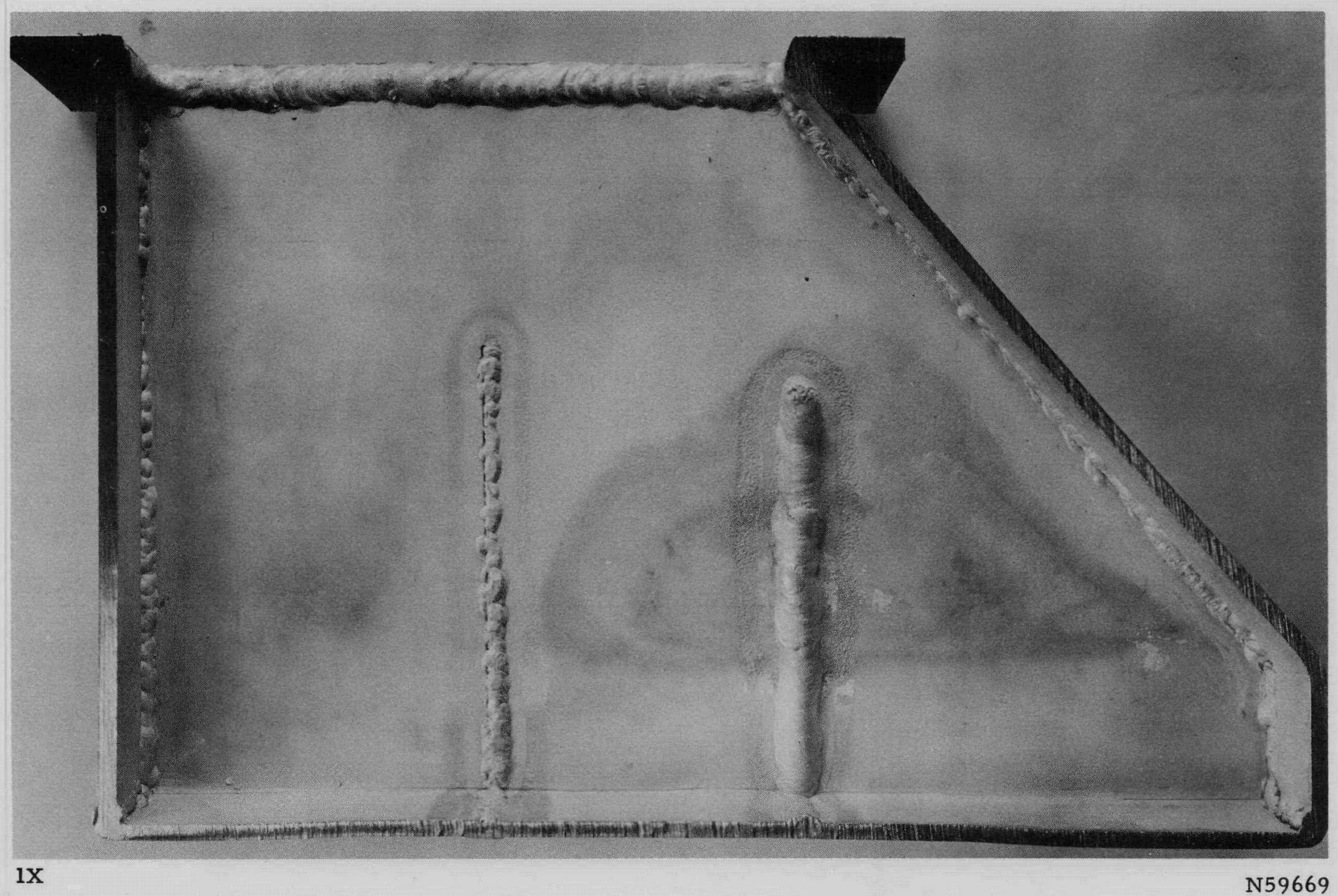

FIGURE 16. SECTION OF NI-O-NEL DISSOLVER FOLLOWING DISSOLUTION STUDY

Notice the bands of localized attack surrounding the centrally located unannealed weldments. 


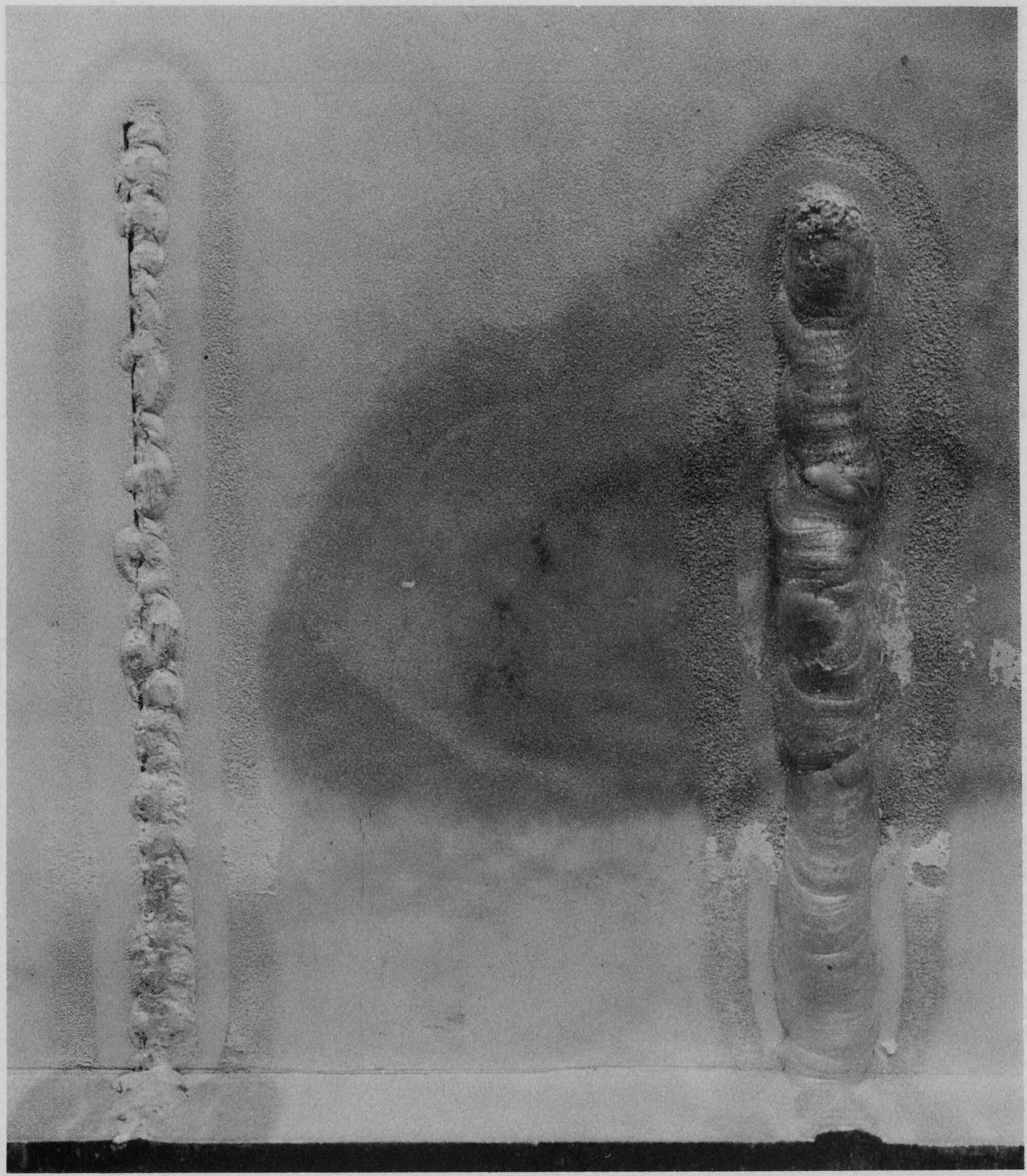

FIGURE 17. MAGNIFIED PORTION OF NI-O-NEL DISSOLVER SHOWING LOCALIZED ATTACK AROUND UNANNEALED WELDMENTS

The other weldments in the dissolver were given a solution anneal following welding and did not exhibit this attack. 
The container was sectioned in several locations and the thickness of the sound metal remaining at these locations was determined by metallography. Thicknesses (in mils) and approximate locations of these sections are shown on the schematic diagram of one-half of the dissolver shown in Figure 18. The sandblasting and pickling of the dissolver prior to the start of the dissolution made it difficult to secure accurate thickness measurements prior to the experiment. The nominal original thickness prior to sandblasting and pickling of the folded-out vertical side shown in Figure 18 was about $127 \mathrm{mils}$, while that of all the other pieces was about 114 mils. Of course, this original thickness may have varied by \pm 1 to 2 mils.

The locations of several sections from which photomicrographs were prepared are also designated in Figure 18. These locations were selected to show representative types of corrosion.

The structure of the thicker of the two unannealed weldments is shown in Figure 19. This weldment was made with good shielding techniques. The observable intergranular penetration is 5 or more mils deep in this weldment. However, the depth of visible intergranular penetration should not be considered to be the maximum penetration, since the outer crystals may have sloughed off just prior to sectioning. The metallographic section, on the other hand, constitutes a measure of the minimum attack in an area.

The structure and attack in the area of the deeply etched groove surrounding the thick unannealed weldment are shown in Figure 20. This was the most severely attacked area in the dissolver. The visible penetration was 8 to 9 mils, not counting, as indicated by the thickness measurements of 95 and $97 \mathrm{mils}$ in this area, the material that obviously sloughed off prior to examination. To illustrate the magnitude of attack here, the approximate loss in thickness of 19 mils (114-95) can be converted to a corrosion rate of about 49 mils per month of continuous dissolver operation.

Out beyond this deep groove surrounding the weldment intergranular attack was still present and fairly severe (visible penetration averaging 2 to $2.5 \mathrm{mils}$ ). This area is shown in Figure 21.

A crevice formed by incomplete penetration of the filler weld can be seen along the side of the weld bead of the other unannealed weldment in Figure 17. This is the weldment made with poor shielding. A cross section taken through this crevice is shown in Figure 22.

Intergranular attack is evident on both the weld and parent metal. However, there is no indication of an exaggerated attack at the bottom of the crevice. No attack seemed to result from the crevices formed by the coupon-type specimens resting on the bottom of the container. This constitutes partial evidence that crevice attack will not be significant in a $\mathrm{Ni-o-nel} \mathrm{dissolver.}$

In contrast to the se areas of fairly high attack, Figure 23 contains photomicrographs of cross sections through one of the vertical annealed weldments in the corner of the dissolver. The intergranular attack is insignificant on the weld bead and the surrounding heat-affected areas. This was true all along these vertical weldments. Based on the thickness measurements along the corner weldment, the attack was least severe in this area. 


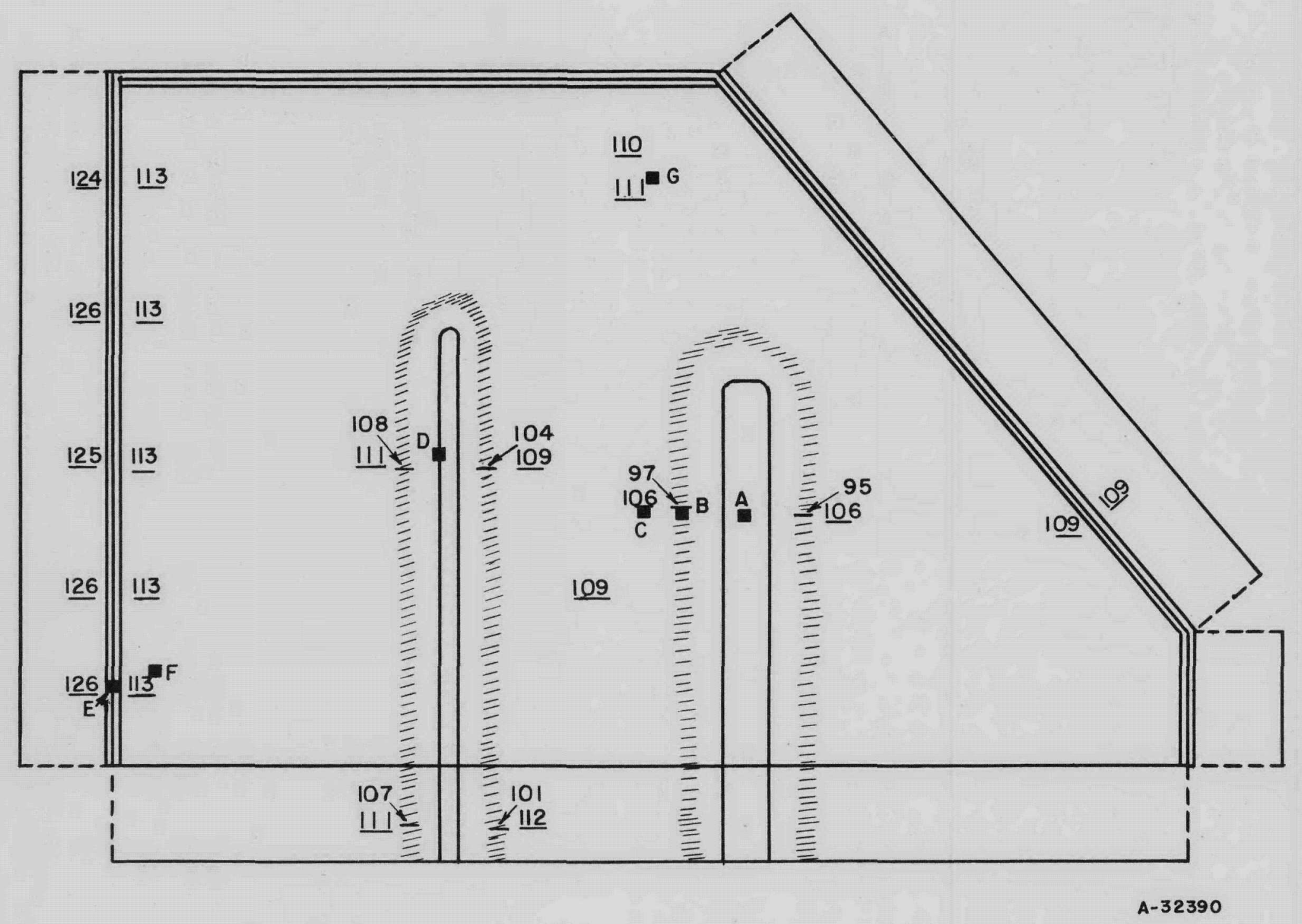

FIGURE 18. SCHEMATIC DIAGRAM OF ONE-HALF OF NI-O-NEL DISSOLVER SHOWING THICKNESSES MEASURED BY METALLOGRAPHY AND THE LOCATION OF SECTIONS PRESENTED IN PHOTOMICROGRAPHS

Thicknesses in mils 


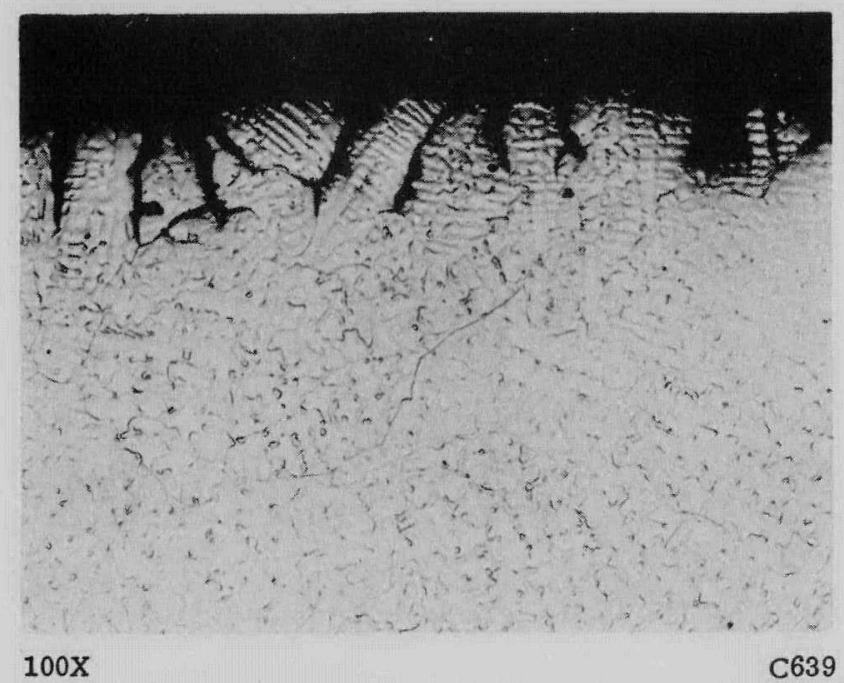

FIGURE 19. STRUCTURE AND INTERGRANULAR ATTACK OF UNANNEALED WELDMENTS IN WALL OF NI-O-NEL DISSOLVER

This section was taken at Location A in Figure 18. The visible penetration was at least 5 mils deep in this area.

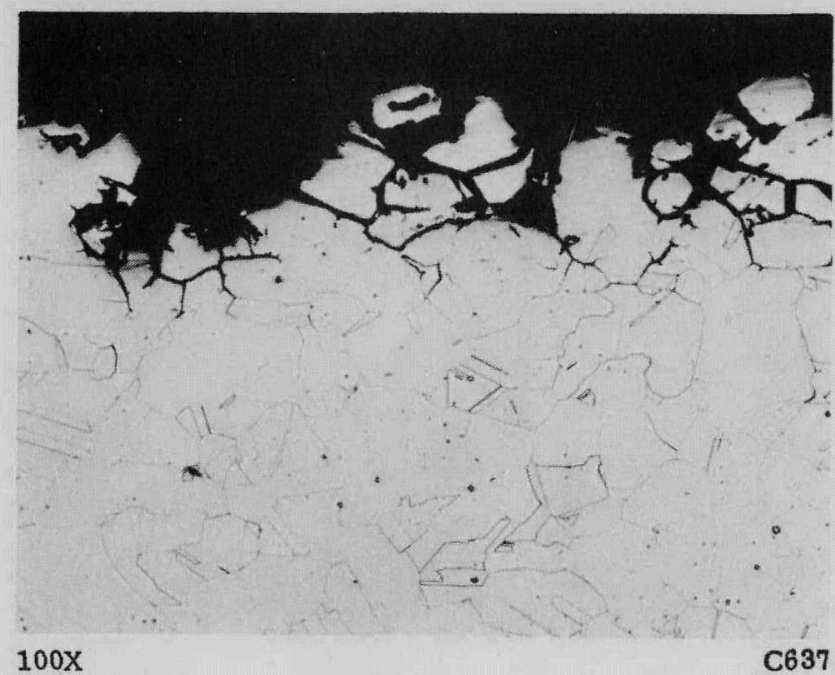

FIGURE 20. STRUCTURE AND INTERGRANULAR ATTACK OF HEAT-AFPECTED AREA SURROUNDING UNANNEALED WELDMENT IN WALL OF NI-O-NEL DISSOLVER

This section was taken at Location B in Figure 18. The corrosion was most severe in this area of the dissolver. The visible penetration was 8 to 9 mils. 


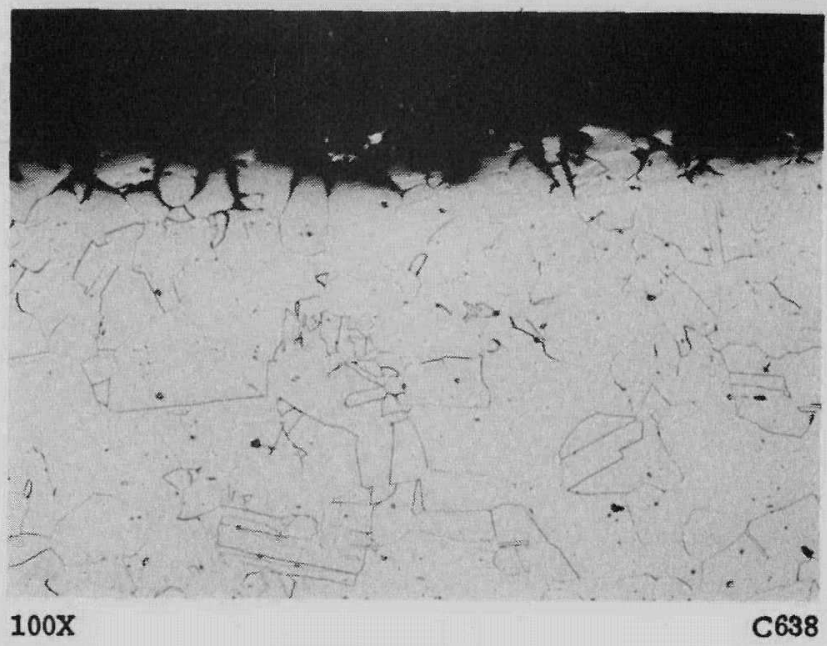

FIGURE 21. STRUCTURE AND INTERGRANULAR ATTACK BEYOND DEEP GROOVE SURROUNDING UNANNEALED WELDMENT IN WALL OF NI-O-NEL DISSOLVER

This section was taken at Location $C$ in Figure 18. The visible penetration averaged 2 to 2.5 mils.

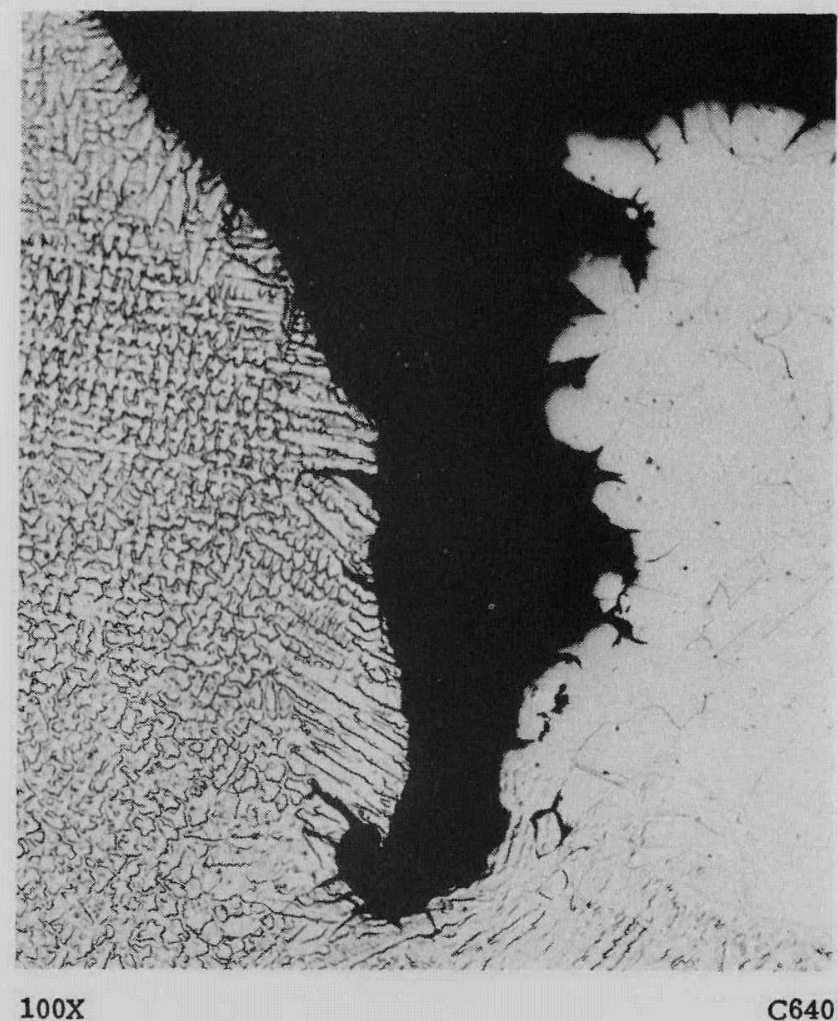

FIGURE 22. CROSS SECTION THROUGH CREVICE CREATED BY INCOMPLETE PENETRATION OF UNANNEALED WELDMENT IN WALL OF NI-O-NEL DISSOLVER

This section was taken at Location D in Figure 18. While intergranular corrosion is visible in both the weld and parent metal, there is no evidence of heavier attack at the bottom of the crevice. 


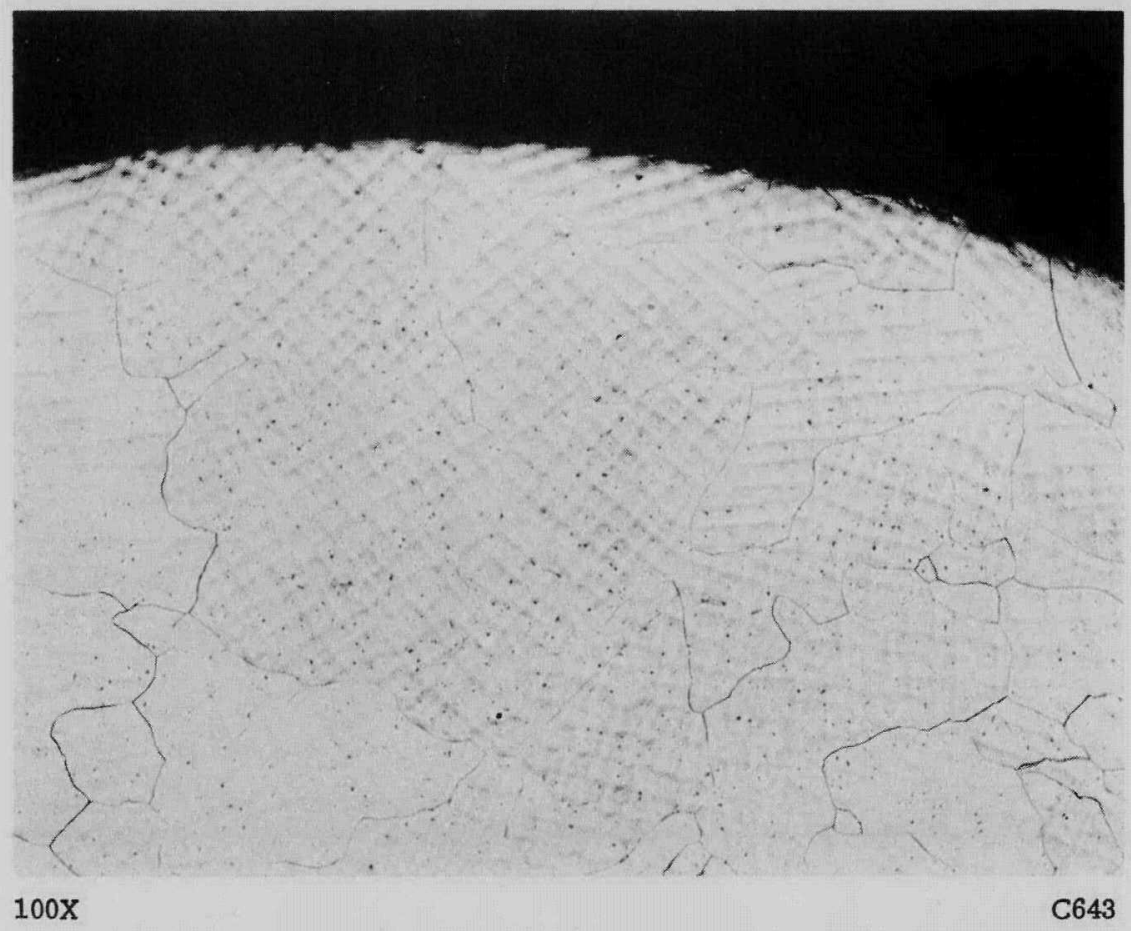

a. Weldment

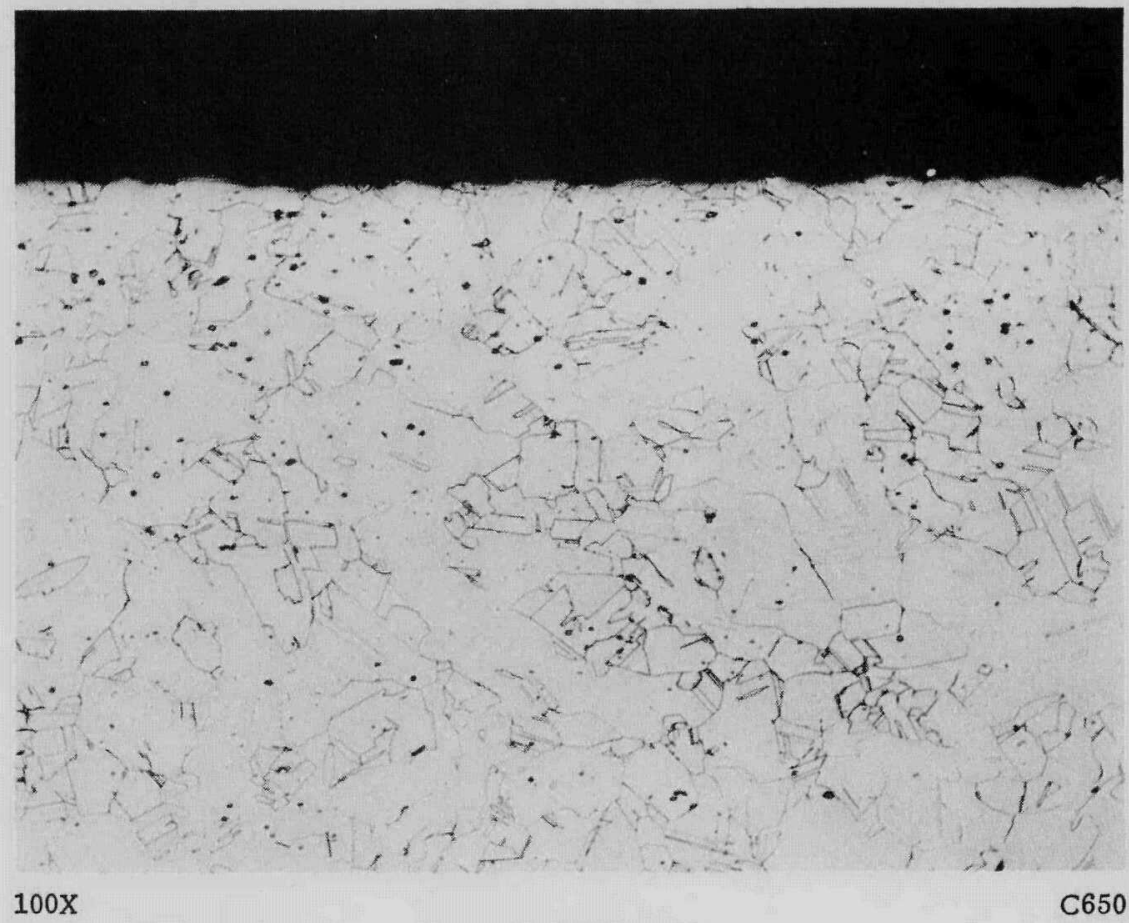

b. Surrounding Area

FIGURE 23. CROSS SECTION THROUGH ANNEALED WELDMENT AND SURROUNDING AREA IN WALL OF NI-O-NEL DISSOLVER

Sections were taken at Locations E and F, Figure 18. 
A cross section taken through the wall of the dissolver in the portion contacted only by the vapors and at a location not associated with any weldments is shown in Figure 24. Here the visible penetration by intergranular attack varies from 1 to 2 mils per month and thickness measurements indicate a significant loss of metal.

The attack on the condenser is shown in Figures 25 and 26. The exposed surface of the condenser flange is shown in Figure 26 along with a $2 \mathrm{X}$ view of the lower inside portion of the condenser tube. The etched area of the flange contrasts plainly in Figure 26 with the unattacked metal protected by the gasket. The lower portion of the condenser tube near the weldment also showed attack. (The small circular areas visible in the photograph are weld spatter.) Several sections were taken through the flange and condenser and examined by metallographic techniques.

A cross section taken through the flange is shown in Figure 25. The maximum visible intergranular penetration was only about $1 \mathrm{mil}$.

The weldment joining the condenser to the flange and the heat-affected area around it had visible penetrations of about 5 mils, as would be expected in this unannealed weldment.

The metallographic study indicates that weldments in a Ni-o-nel container for Sulfex-Thorex dissolutions must be solution annealed to prevent the occurrence of severe intergranular attack.

Even the unwelded metal shows evidence of intergranular attack both above and below the liquid line. Some portions of the dissolver walls appear to be more severely attacked than others. This may arise from hot spots created on the walls during the preheating and early stages of the decladding operation or possibly from the scale which formed at various locations on the walls during the dissolutions.

While it is not possible to get an accurate measurement of the metal loss, it is felt, in view of the pattern of the measurements taken and the results with the corrosion coupons, that the general corrosion of the walls is in the range of 5 mils per month, with some areas showing even higher rates. This figure is based on continuous operation of the dissolver and does not take into account the obviously higher rates found around unannealed weldments. It was found (Appendix B) that the valence states of the corrosion products, especially chromium, affect the corrosion rates of Ni-o-nel in Thorex solutions. Conceivably, the valence states of these corrosion products will be significantly altered in the presence of irradiation and, consequently, the corrosion rates will be different. Since the corrosion around the unannealed weldments contributed considerably to the concentration of corrosion products in the Thorex solutions, a longe $r$ dissolution study in a vessel in which all the weldments are annealed is recommended to clarify the situation. 


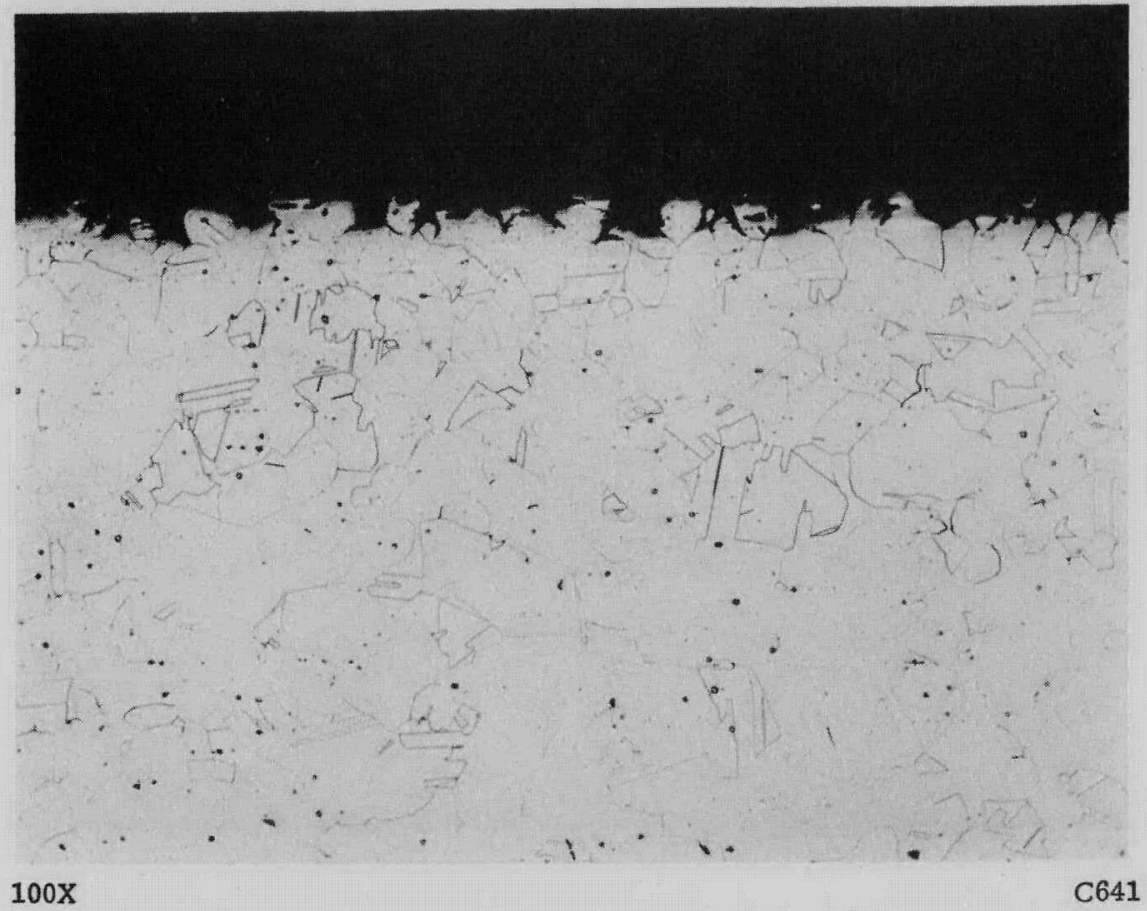

FIGURE 24. CROSS SECTION THROUGH WALL OF NI-O-NEL DISSOLVER IN PORTION CONTACTED ONLY BY THE VAPOR PHASE

Section was taken at Location G in Figure 18.

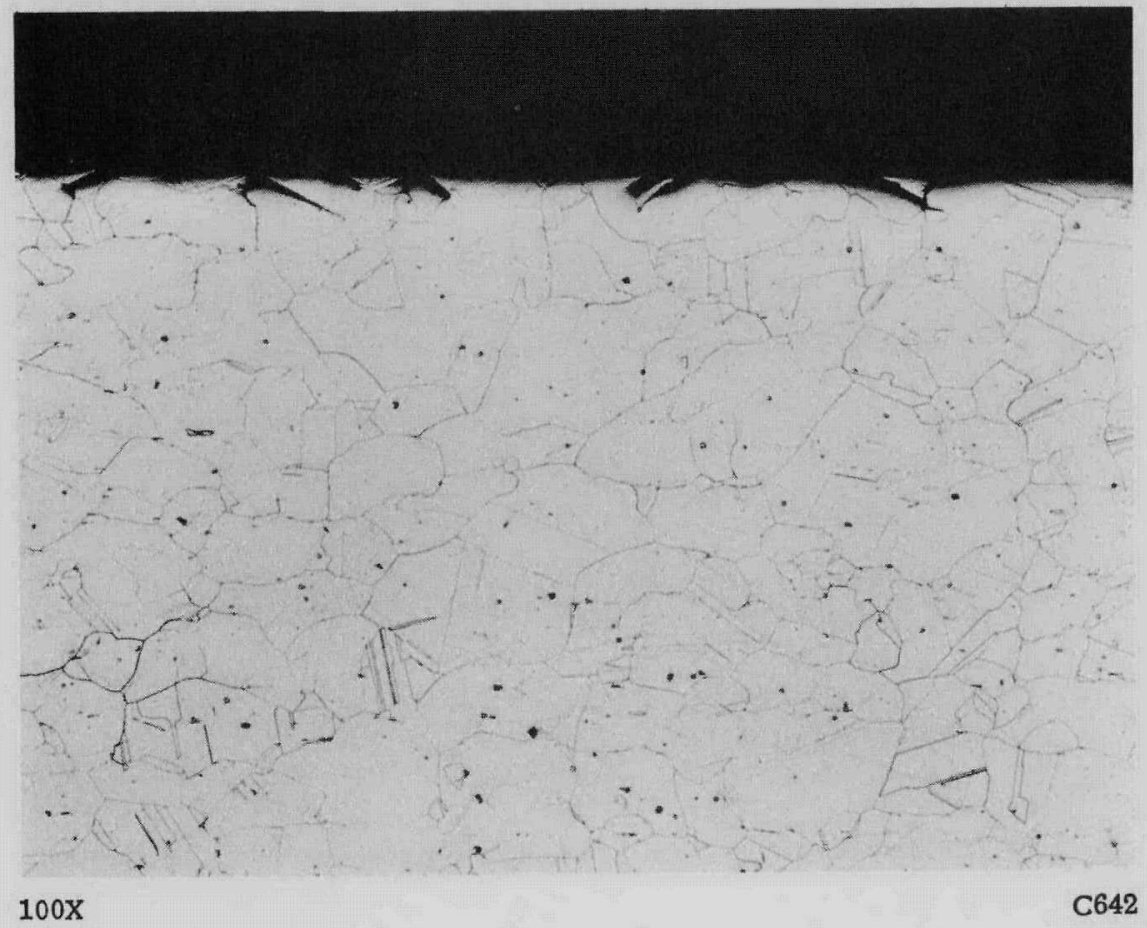

FIGURE 25. CROSS SECTION SHOWING EXPOSED SURFACE OF CONDENSER FLANGE OF THE NI-O-NEL DISSOLVER

The maximum visible intergranular penetration was only about $1 \mathrm{mil}$. 


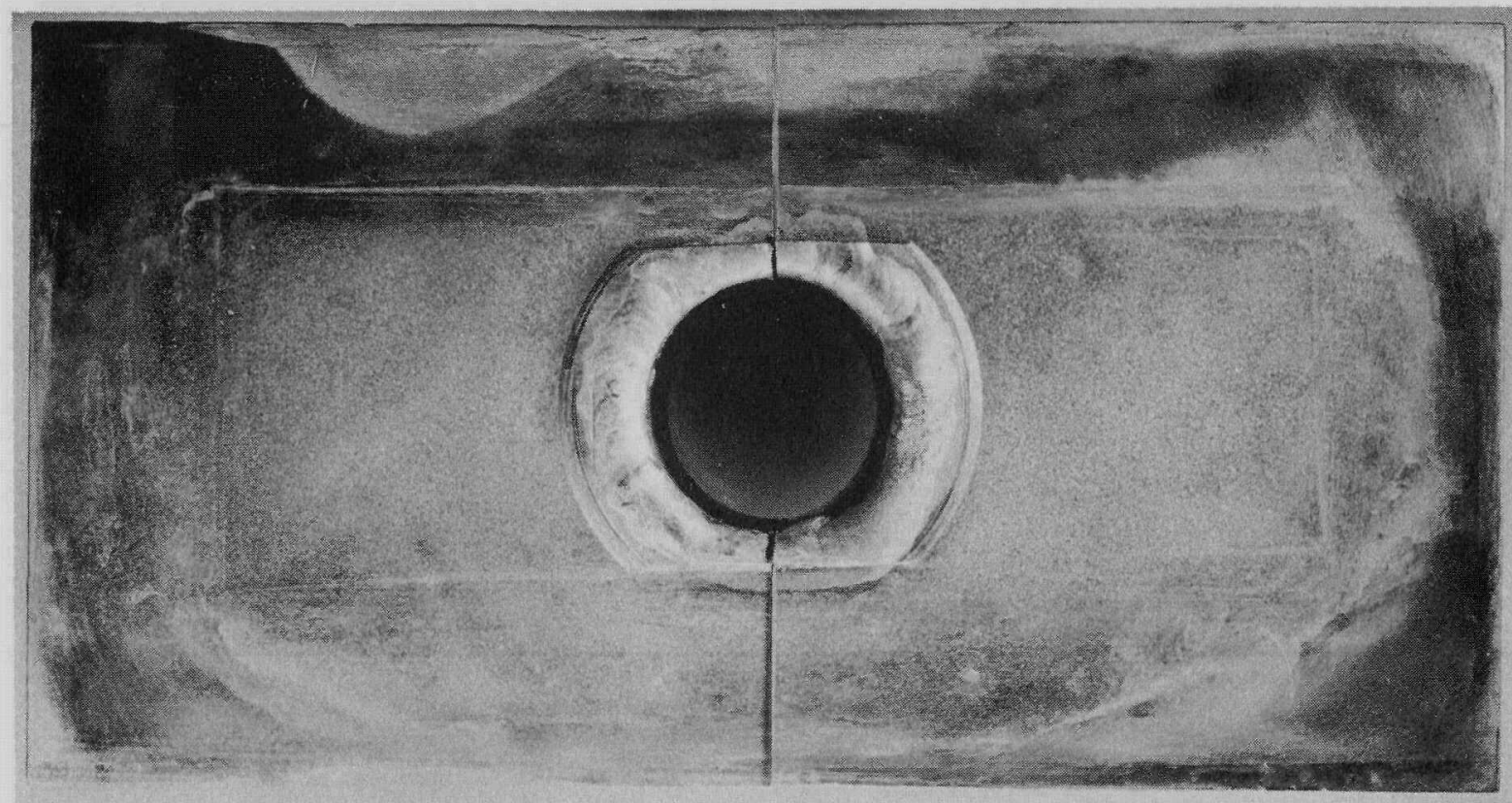

$1 \mathrm{x}$

N59670

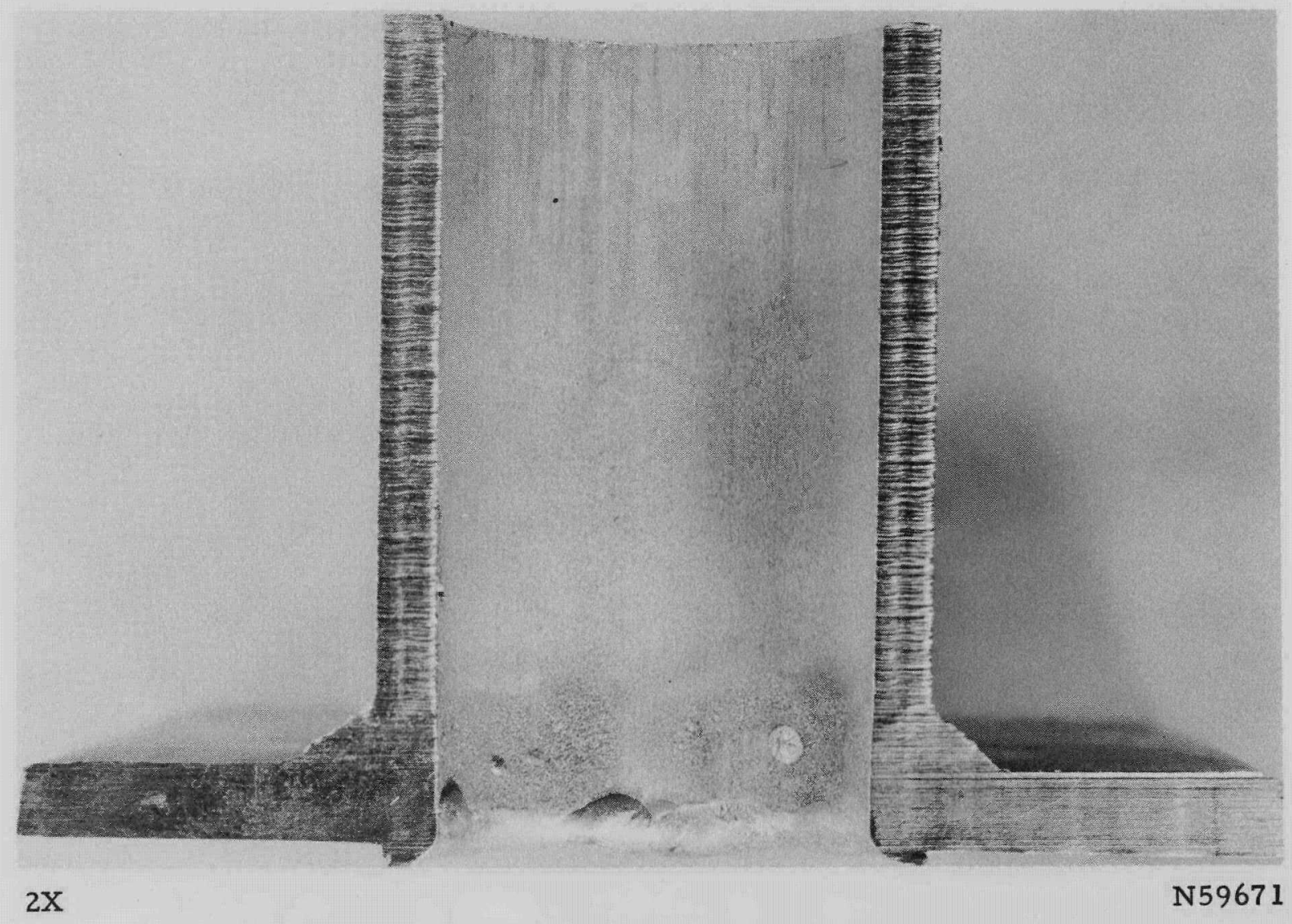

FIGURE 26. EXPOSED SIDE OF BOTTOM FLANGE AND SECTION THROUGH FLANGE AND CONDENSER OF NI-O-NEL DISSOLVER 
The possibility of a combined Darex-Thorex process was conceived by ORNL when investigators in the Chemical Technology Division observed relatively little attack on titanium specimens exposed to Thorex core-dissolution solutions. If titanium would withstand the core-dissolution step, fuel elements of the Consolidated Edison type could be dejacketed by the Darex process and the core dissolution could be carried out in the Darex dissolver. The attractiveness of reprocessing Consolidated Edison fuel elements in equipment already planned at ORNL led to further investigation of the corrosion of titanium by Thorex solutions.

\section{Scouting Experiments With Titanium}

Scouting evaluations were conducted in boiling Thorex solutions using small coupons of Titanium 75A containing either butt or lap weldments. The lap-welded coupons had a bead at each end of the lap so that a narrow crevice was formed in between. The studies were conducted under reflux conditions using units composed of Kel-F bottles topped by water-jacketed Teflon condensers. After exposure, specimens were scrubbed with a brush, prior to drying and weighing, to remove the loose scale or precipitate which formed on their surfaces. Corrosion rates were calculated only for the butt-welded specimens, since area measurements on the lap-welded coupons were subject to error. Weight changes were followed on the latter type of specimens and these agreed, in general, with those measured on the butt-welded coupons. The corrosion rates for the butt-welded coupons are tabulated in Table 14. The vapor-phase, butt-welded specimens are shown, following the 1000-hr exposure in Figure 27.

The data indicated several things. Corrosion was highest in the vapor phase in all cases. At the $0.04 \mathrm{M}$ level, aluminum additions gave more inhibition than thorium. The Thorex solution became less corrosive as the core dissolution progressed.

The corrosion rates for titanium specimens exposed to Initial Thorex solution were relatively high, but not so excessive as might have been predicted prior to this series of experiments. These specimens were attacked uniformly and left with smooth shiny surfaces (Specimen A, Figure 27). In the presence of $0.04 \mathrm{M} \mathrm{Al}^{+3}$, a black coating formed on the specimens and the attack, underneath, appeared to be fairly uniform. However, as the aluminum additions were increased through 0.09 and 0.15 to $0.20 \mathrm{M}$, localized attack increased on the vapor-phase specimens. At 0.09 and $0.15 \mathrm{M} \mathrm{Al}+3$ this took the form of numerous scattered small pits. With $0.20 \mathrm{M}$ the entire surface of the vapor-phase specimen was etched, and the attack was somewhat more severe on the weldment and heat-affected areas. The vapor-phase specimens exposed to Middle and Final Thorex solutions also showed this general etching. Numerous small pits were scattered over the etched surface. Metallographic examination showed these pits averaged 5 to $10 \mathrm{mils}$ in diameter and 1 to 2 mils deep. The bottoms of the pits were rounded and did not contain any cracks or fissures. The crevices formed by the lapwelded specimens appeared to be free from localized attack. Figure 28 shows photomicrographs of cross sections taken outside the heat-affected areas of two butt-welded specimens exposed in the vapor phases above Initial Thorex solutions with 0.04 and $0.20 \mathrm{M} \mathrm{Al}^{+3}$ additions. The roughened and pitted surface that occurred with the $0.20 \mathrm{M}$ addition can be compared with the smooth surface of the other specimen. 
TABLE 14. RESULTS OF SCOUTING EVALUATIONS OF BUTT-WELDED TITANIUM 75A EXPOSED TO BOILING THOREX SOLUTIONS

\begin{tabular}{|c|c|c|c|c|c|c|c|c|c|c|}
\hline \multirow{2}{*}{$\begin{array}{l}\text { Thorex } \\
\text { Solution }^{(a)}\end{array}$} & \multirow{2}{*}{$\begin{array}{c}\text { Molar } \\
\text { Addition }\end{array}$} & \multirow{2}{*}{$\begin{array}{c}\text { Specimen } \\
\text { Position }\end{array}$} & \multicolumn{7}{|c|}{ Corrosion Rate at Time Shown, mils per month } & \multirow{2}{*}{$\begin{array}{c}\text { Specimen } \\
\text { Designation } \\
\text { in Figure } 27\end{array}$} \\
\hline & & & $24 \mathrm{Hr}$ & $96 \mathrm{Hr}$ & $240 \mathrm{Hr}$ & $363 \mathrm{Hr}$ & $501 \mathrm{Hr}$ & $756 \mathrm{Hr}$ & $1000 \mathrm{Hr}$ & \\
\hline \multirow[t]{3}{*}{ Initial } & \multirow[t]{3}{*}{$-\infty$} & Vapor & $g^{(b)}$ & 6.7 & 7.2 & 10 & 9.1 & 8.1 & 7.3 & A \\
\hline & & Interface & 7.5 & 8.1 & 8.1 & 8.4 & 7.8 & 6.5 & 5.8 & - \\
\hline & & Liquid & 11 & 9.0 & 8.1 & 7.7 & 7.2 & 5.9 & 5.1 & -- \\
\hline \multirow[t]{3}{*}{ Initial } & \multirow[t]{3}{*}{$0.04 \mathrm{Al}^{+3}$} & Vapor & 1.4 & 1.9 & 1.4 & 1.8 & 1.7 & 1.7 & 1.6 & B \\
\hline & & Interface & 0.60 & 0.51 & 0.71 & 0.67 & 0.63 & 0.50 & 0.43 & - \\
\hline & & Liquid & 1.2 & 0.59 & 0.81 & 0.67 & 0.61 & 0.45 & 0.36 & -- \\
\hline \multirow[t]{3}{*}{ Initial } & \multirow[t]{3}{*}{$0.09 \mathrm{Al}^{+3}$} & Vapor & $\mathrm{g}$ & 1.6 & 0.73 & 0.89 & 0.77 & 0.53 & 0.39 & C \\
\hline & & Interface & 0.39 & 0.02 & $g$ & $\mathrm{~g}$ & $\mathrm{~g}$ & $g$ & $\mathrm{~g}$ & - \\
\hline & & Liquid & 0.37 & 0.02 & g & g & g & $g$ & g & -- \\
\hline \multirow[t]{3}{*}{ Initial } & \multirow[t]{3}{*}{$0.15 \mathrm{Al}^{+3}$} & Vapor & 0.00 & 0.02 & 0.00 & 1. 2 & 1.5 & 0.98 & 0.75 & D \\
\hline & & Interface & 0.26 & 0.45 & g & 0.04 & 0.07 & 0.03 & 0.01 & $-\infty$ \\
\hline & & Liquid & 0.31 & 0.05 & g & g & g & g & g & - \\
\hline \multirow[t]{3}{*}{ Initial } & \multirow[t]{3}{*}{$0.20 \mathrm{Al}^{+3}$} & Vapor & 0.45 & 0.64 & 2.0 & 2.8 & 2.0 & 3.4 & $3.4^{(c)}$ & E \\
\hline & & Interface & 0.31 & 0.03 & 0.19 & 0.29 & 0.20 & 0.29 & $0.40^{(\mathrm{c})}$ & $\ldots$ \\
\hline & & Liquid & 0.21 & & $g$ & $g$ & $\mathrm{~g}$ & $g$ & $g(c)$ & -- \\
\hline \multirow[t]{3}{*}{ Initial } & \multirow[t]{3}{*}{$0.04 \mathrm{Th}^{+4}$} & Vapor & 0.33 & 6.0 & 9.5 & 9.0 & 10 & 6.9 & 7.2 & $\mathrm{H}$ \\
\hline & & Interface & 3.5 & 3.1 & 3.8 & 3.6 & 4.0 & 2.8 & 2.6 & - \\
\hline & & Liquid & 1.7 & 2.5 & 2.5 & 2.6 & 2.3 & 1.8 & 1.7 & -- \\
\hline \multirow[t]{3}{*}{ Middle } & \multirow[t]{3}{*}{$0.04 \mathrm{Al}^{+3}$} & Vapor & 0.03 & 0.03 & 3.1 & 2.0 & 2.8 & 2.1 & 2.7 & F \\
\hline & & Interface & 0.25 & 0.04 & 0.24 & 0.15 & 0.20 & 0.11 & 0.13 & $-\infty$ \\
\hline & & Liquid & 0.26 & 0.06 & g & $g$ & g & g & $g$ & $-\infty$ \\
\hline \multirow[t]{3}{*}{ Final } & \multirow[t]{3}{*}{$0.04 \mathrm{Al}^{+3}$} & Vapor & 0.03 & 0.54 & 0.96 & 1.1 & 1.3 & 1.6 & 1.5 & G \\
\hline & & Interface & 0.22 & 0.09 & 0.28 & 0.41 & 0.37 & 0.59 & 0.61 & $-\infty$ \\
\hline & & Liquid & 0.41 & 0.14 & 0.09 & 0.10 & 0.19 & 0.10 & 0.19 & -- \\
\hline
\end{tabular}

(a) Solution compositions:

$$
\begin{array}{ll}
\text { Initial } & 13.0 \mathrm{MHNO}_{3}, 0.04 \mathrm{MF}^{-} \\
\text {Middle } & 10.8 \mathrm{MNNO}_{3}, 0.04 \mathrm{M} \mathrm{F}^{-1}, 0.50 \mathrm{M} \mathrm{Th}^{+4} \\
\text { Final } & 8.5 \mathrm{MNO}_{3}, 0.04 \mathrm{MF}^{-}, 1.0 \mathrm{M} \mathrm{Th}^{+4}
\end{array}
$$

(b) g indicates a small gain in weight.

(c) These specimens were removed after $915 \mathrm{hr}$ of exposure. 

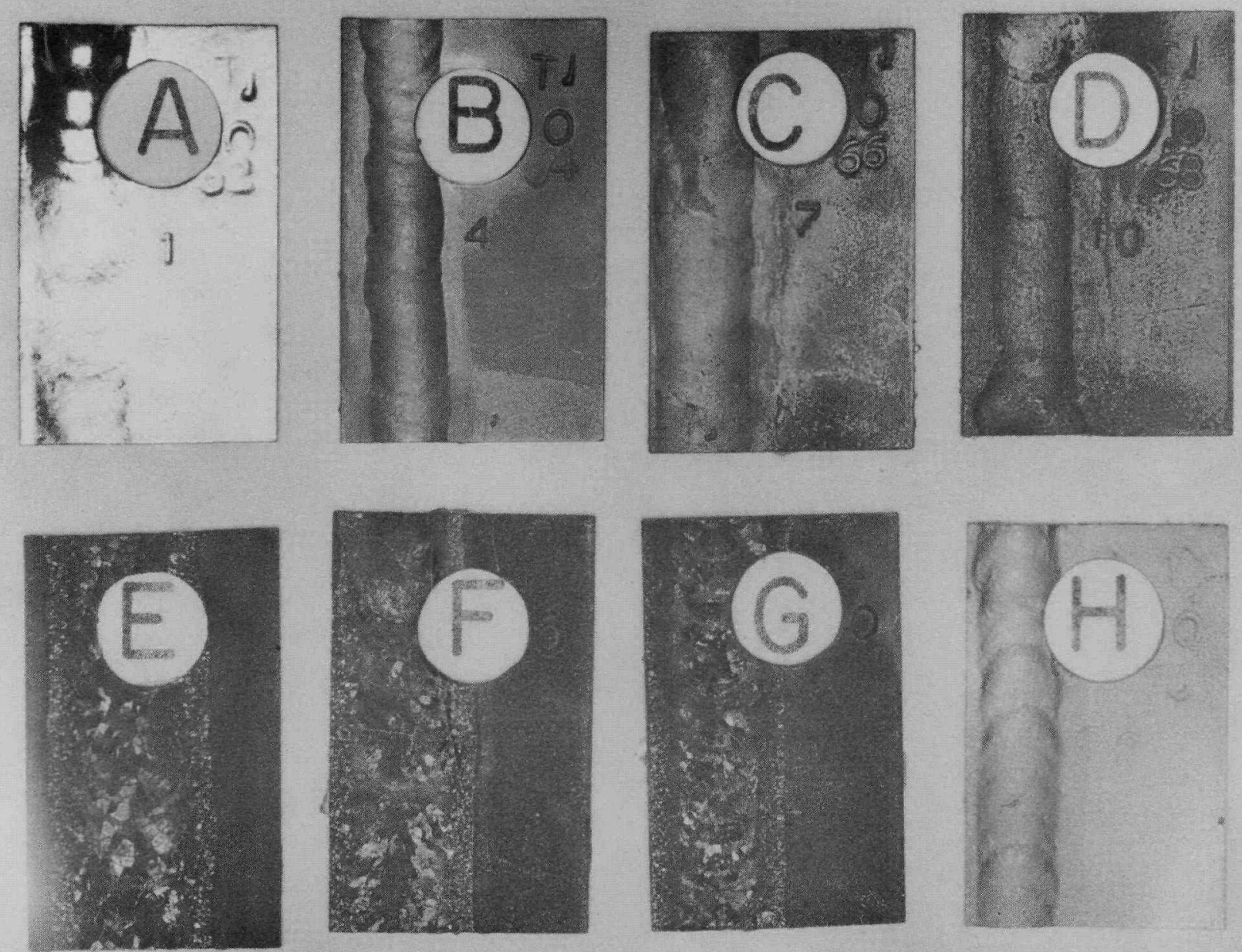

$\sim 4 \mathrm{X}$

N59184

FIGURE 27. VAPOR-PHASE TITANIUM 75A SPECIMENS FOLLOWING $1000 \mathrm{HR}$ OF EXPOSURE TO VARIOUS THOREX SOLUTIONS

See Table 14 for specimen identification. 


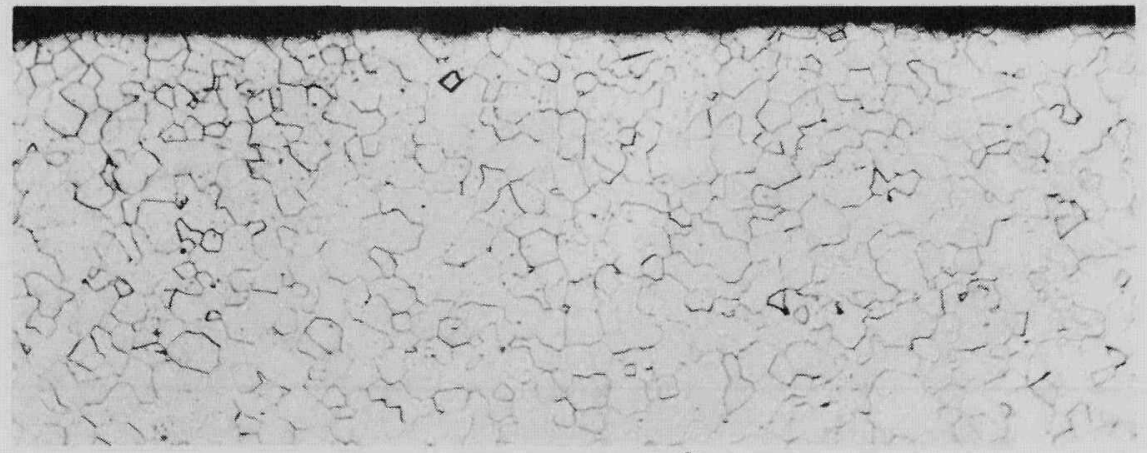

a. $0.04 \mathrm{M} \mathrm{Al}^{+3}$

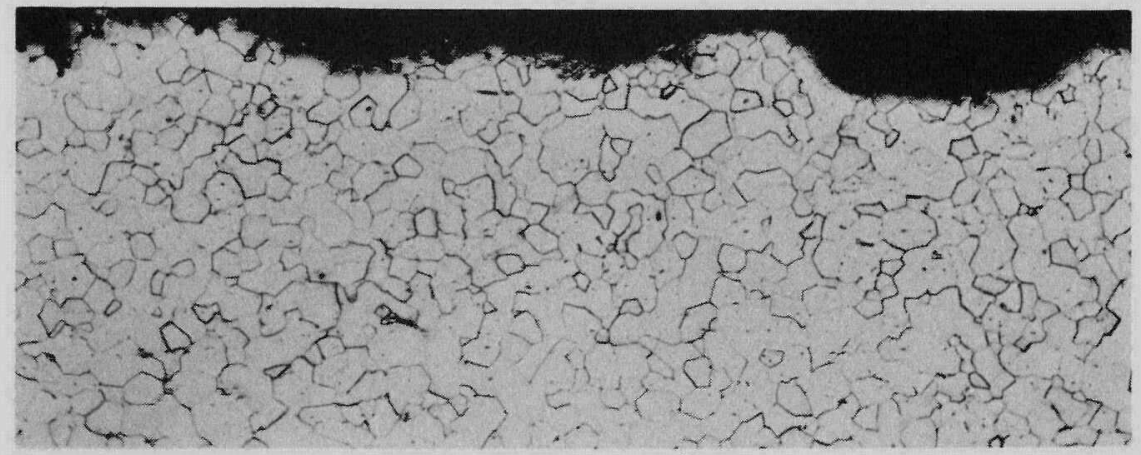

b. $0.20 \mathrm{M} \mathrm{Al}^{+3}$

$100 \mathrm{X}$

$\mathrm{C} 636$

FIGURE 28. EFFECT OF THE AMOUNT OF ALUMINUM ADDITION ON THE SURFACE ATTACK ON VAPOR-PHASE SPECIMENS OF TIT ANIUM 75 A AFTER EXPOSURE FOR 1000 HR TO BOILING INITIAL THOREX (13.0 $\mathrm{M} \mathrm{HNO}_{3}, 0.04 \mathrm{M}$ F) SOLUTION 
It appears that, as more fluoride is complexed in solution, the fluoride concentration in the vapor decreases. Below some value for the fluoride concentration in the vapor, the attack changes from general to localized. Since localized attack may lead to vessel failure faster than general attack, and since the solution becomes less corrosive as thorium is dissolved, it might be advantageous to accept the relatively high rate of general attack which would occur for a short time in the early part of core dissolution in the absence of aluminum in order to minimize the over-all corrosion. This point should be thoroughly investigated before an operating procedure with aluminum additions is adopted.

Other investigators have reported rather high rates of attack for RC-55 titanium in the presence of fluoride and chloride contaminations together. (6) In this case, no aluminum additions were made and the rates were not considerably higher than those occurring during studies at BMI with fluoride alone. However, since chloride carryover is possible in the core dissolution by the Darex-Thorex route, two duplicate studies were conducted to determine its effect.

Both plain and welded Titanium 75A specimens were exposed to boiling Initial

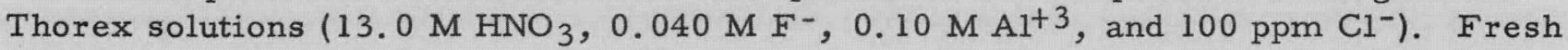
solutions were used after each weekly inspection. The data from these studies are shown in Table 15.

The corrosion rates remained low during this exposure. However, a considerable amount of pitting occurred on the specimens. The pits were scattered over the surfaces but were most prevalent on cut edges, around the sharp corners caused by imprinting designation numbers, and along weldments. The specimens exposed to the vapor were pitted more severely than those exposed to the liquid. The average pit was about $20 \mathrm{mils}$ in diameter and about 3 to $5 \mathrm{mils}$ deep. The bottoms of most of the pits were bright gold in color. The submerged specimens were dull gray-black in color and showed only the isolated pits mentioned. The vapor-phase specimens were tarnished with an iridescent oxide film. Their surfaces were covered with numerous small pits in addition to the isolated larger ones, and, in many cases, the entire surface was roughened by a fine-grained etch. A section through one of the pitted areas is shown in Figure 29. The deposits at the bottoms of the pits are visible.

The solutions were changed weekly, but this was not often enough to insure retaining the desired $100 \mathrm{ppm} \mathrm{Cl}{ }^{-}$. Analyses of three solutions after exposure showed that less than $5 \mathrm{ppm} \mathrm{C1} 1^{-}$remained in two cases and $10 \mathrm{ppm}$ in the third. Conceivably, the pitting might have been more severe if the chloride concentration had been maintained. Aluminum chloride has been reported to cause pitting of titanium. (7) Further investigations should be conducted in which the chloride concentration is maintained but aluminum additions are omitted. Similar pitting was not observed on the titanium dissolver following the dissolution of 25 fuel pins. Certainly chloride contamination occurred during these dissolutions. However, the time may have been too short for the pitting attack to become established. The problem of pitting should be thoroughly investigated before titanium is recommended for the Darex-Thorex process as it might be sufficiently severe to cause difficulties during the operation of a plant. 
50

TABLE 15. RESULTS OF EXPOSURE OF TITANIUM 75A TO BOILING INITIAL THOREX SOLUTION (a) CONTAMINATED WITH 100 PPM CHLORIDE

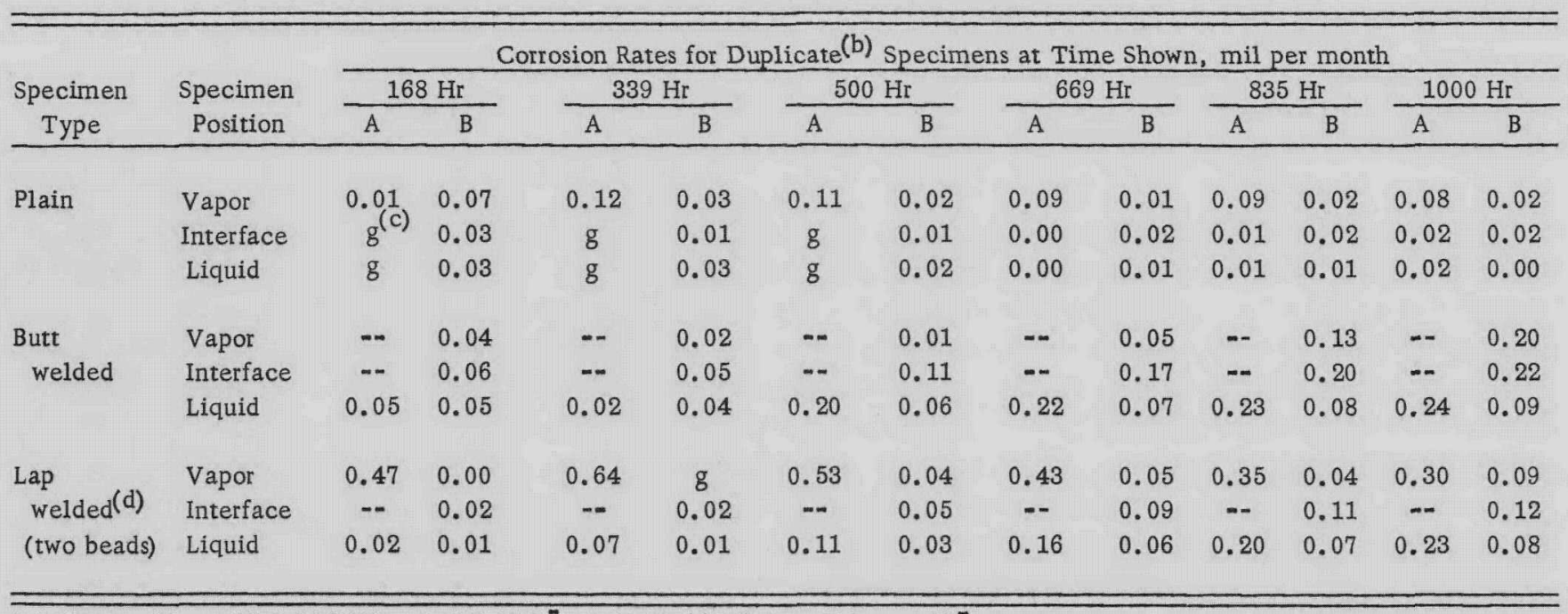

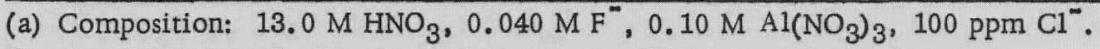

(b) $\mathrm{A}$ and $\mathrm{B}$ denote duplicate specimens exposed in separate containers.

(c) $g$ indicates a small gain in weight.

(d) Based on approximate area of $1.5 \mathrm{in}^{2}$, neglecting area inside crevice. 


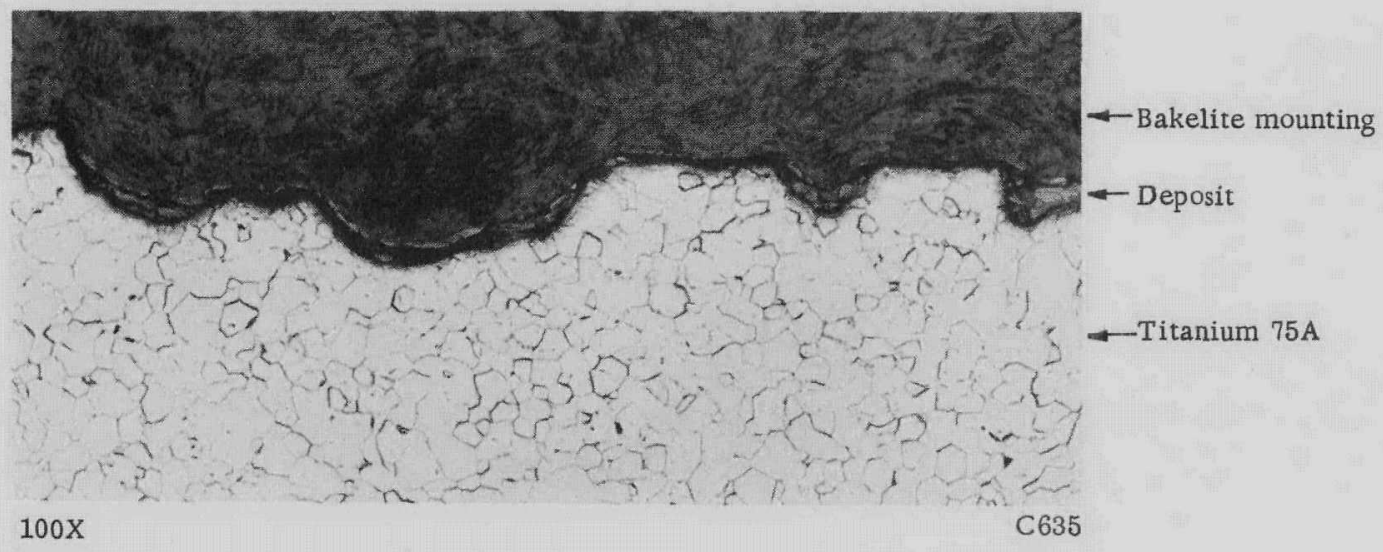

FIGURE 29. CROSS SECTION SHOWING PITTING OF VAPOR-PHASE TITANIUM 75A SPECIMEN AFTER EXPOSURE FOR 1000 HR TO BOILING CHLORIDE-CONTAMINATED INITIAL THOREX SOLUTION (13.0 $\mathrm{M} \mathrm{HNO}_{3}, 0.04 \mathrm{MF}^{-}, 0.10 \mathrm{M} \mathrm{Al}^{+3}, 100 \mathrm{PPM} \mathrm{Cl}^{-}$)

\section{Bench Dissolution of Fuel Pins by a Darex-Thorex Operation}

A dissolver was constructed from Titanium 75A as shown in Figure 14. The condenser tube was made from Titanium A-40. The vessel was fabricated by welding in a dry box using strips of Titanium $75 \mathrm{~A}$ as weld electrodes. No appreciable weld scale formed. However, cracks due to bending sharply to form the container bottom had to be repaired by welding.

Twenty-five Consolidated Edison fuel pins of the same type as described in the discussion of the Sulfex-Thorex experiments were dissolved, one at a time, in this dissolver by a combined Darex-Thorex operation. The schedule for these dissolutions is shown in Figure 30. Again, the solids remaining from previous dissolutions were added to each new dissolution. Aside from the abruptness with which the dissolution starts, which was counteracted by submerging only part of the pin and providing expansion chambers above the condenser to allow room for the evolved liquid to lose its force and drain down to the dissolver, the dissolutions were nearly trouble-free. Passivation of the cladding did not occur. The details of the dissolution are given in Appendix D. The dissolution products were returned to ORNL for analysis. A total of $225 \mathrm{hr}$ under operating conditions was accumulated with this dissolver.

Coupon-type specimens of Titanium 75A were submerged in the dissolver almost from the beginning. Others were suspended in the vapor after nine pins had been processed. These were removed and examined at intervals. The weight changes are shown in Table 16. All of the submerged specimens gained slightly in weight, those in the vapor showed small losses which calculated to be less than 0.1 mil per month. No pitting was found on any of these coupons, nor was there any evidence of crevice attack. The core-dissolution solution was but slightly tinged with colored corrosion products.

Upon sectioning these coupons and studying them metallographically, it was found that each was coated with a nonmetallic-appearing scale. This scale was 0.4 to $0.5 \mathrm{mil}$ 


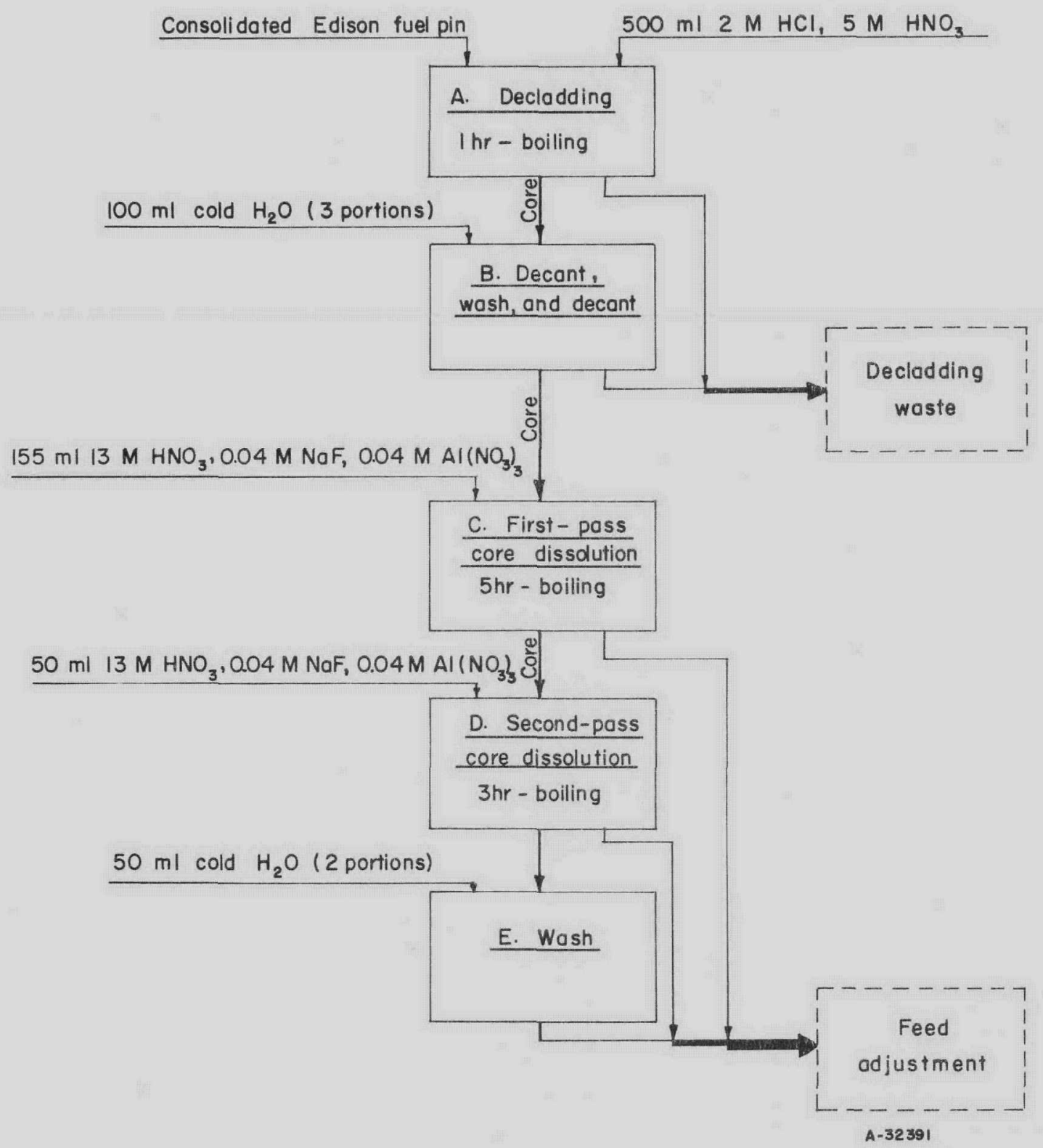

FIGURE 30. SCHEDULE FOR DAREX-THOREX BENCH DISSOLUTION OF CONSOLIDATED EDISON FUEL PINS

Based on information obtained from L. M. Ferris of the Chemical Technology Division of ORNL. 
TABLE 16. RESULTS OF EXPOSURE OF TITANIUM 75A CORROSION SPECIMENS IN DAREX-THOREX DISSOLVER

\section{Specimen Corrosion Data}

\begin{tabular}{|c|c|c|c|c|c|c|c|c|c|}
\hline \multirow[b]{2}{*}{ Specimen } & \multirow{2}{*}{$\begin{array}{c}\text { Approximate } \\
\text { Area, } \\
\text { in. }{ }^{2}\end{array}$} & \multicolumn{7}{|c|}{$\begin{array}{c}\text { Weight Change After Dissolution of Number } \\
\text { of Pins Shown, mg }\end{array}$} & \multirow{2}{*}{$\begin{array}{l}\text { Corrosion Rate Determined } \\
\text { Metallographically After } \\
\text { Dissolution of } 25 \text { Pins, } \\
\text { mils per month }\end{array}$} \\
\hline & & 5 & 10 & 11 & 12 & 15 & 20 & 25 & \\
\hline tats & & \multicolumn{8}{|c|}{ Specimens Exposed in Liquid for Time Shown(a) } \\
\hline & & $36 \mathrm{Hr}$ & $81 \mathrm{Hr}$ & $91 \mathrm{Hr}$ & $99 \mathrm{Hr}$ & $126 \mathrm{Hr}$ & $171 \mathrm{Hr}$ & $216 \mathrm{Hr}$ & $216 \mathrm{Hr}$ \\
\hline Butt welded & 1.2 & -0.7 & -0.5 & +0.2 & +0.3 & +0.6 & +0.2 & +1.0 & 2.5 \\
\hline Butt welded & 4.2 & +1.6 & +2.9 & +5.5 & +5.5 & +10.1 & +9.9 & +11.2 & 0.17 \\
\hline \multirow[t]{3}{*}{ Plain } & 4.2 & +2.8 & +4.4 & +6.3 & +6.7 & +9.1 & +9.2 & +10.9 & 1. 4 \\
\hline & & & & \multicolumn{6}{|c|}{ Specimens Exposed in Vapor for Time Shown (a) } \\
\hline & & & & $18 \mathrm{Hr}$ & $26 \mathrm{Hr}$ & $53 \mathrm{Hr}$ & $98 \mathrm{Hr}$ & $143 \mathrm{Hr}$ & $143 \mathrm{Hr}$ \\
\hline $\begin{array}{l}\text { Lap welded, } \\
\text { two beads }\end{array}$ & 1. 4 & -- & -- & -0.2 & +0.3 & -0.2 & -1.0 & -0.5 & 4.3 \\
\hline Butt welded & 1.2 & -- & -- & -1.3 & -1.2 & -1.1 & -1.9 & $-1.3(b)$ & 3.8 \\
\hline
\end{tabular}

(a) Liquid specimens were exposed after dissolution of one pin, vapor after nine.

(b) A weight loss of $1.3 \mathrm{mg}$ at $143 \mathrm{hr}$ equals $0.08 \mathrm{mil}$ per month 


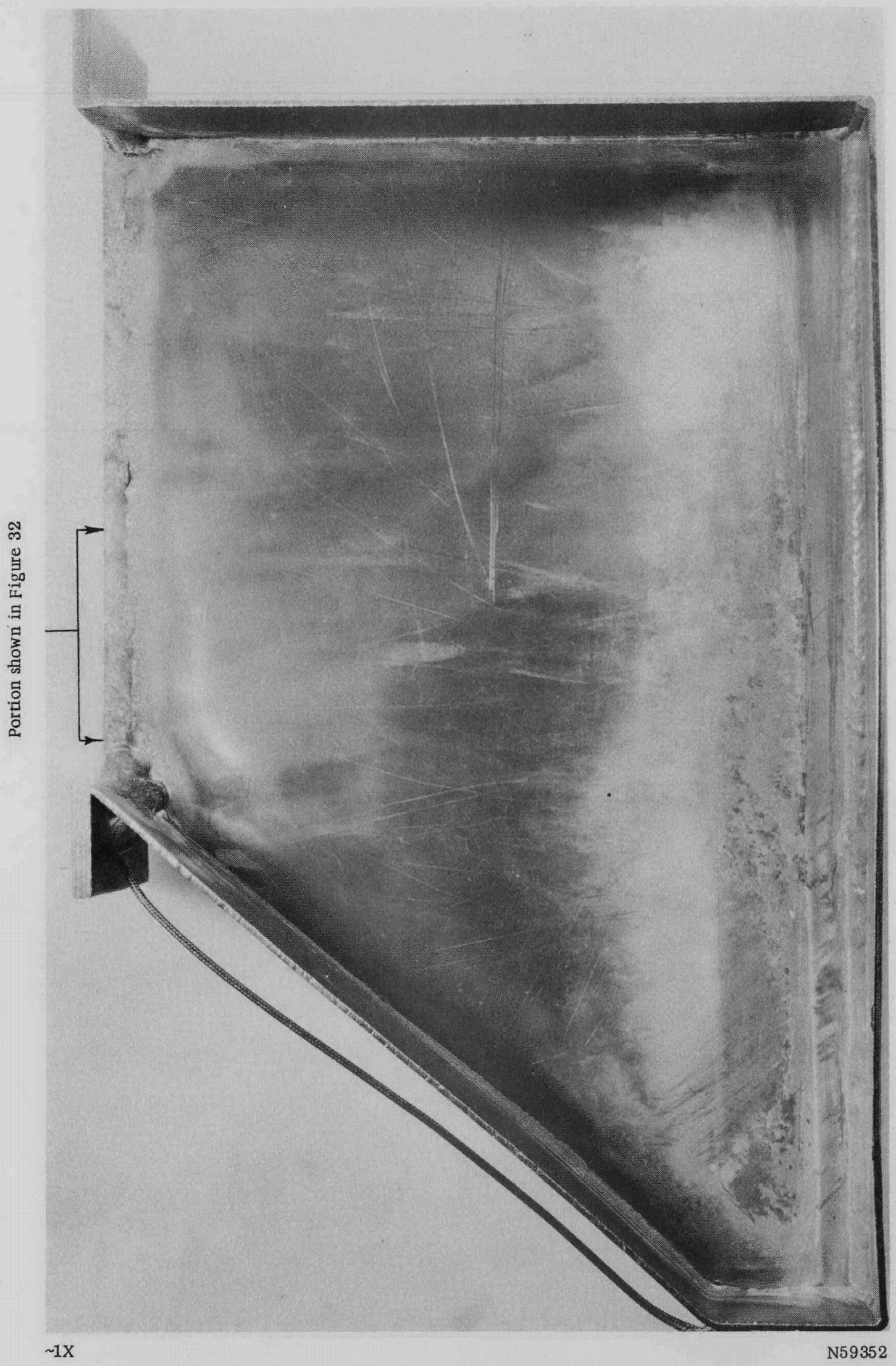

FIGURE 31. TWO HALVES OF TITANIUM 75A DISSOLVER FOLLOWING DAREX-THOREX DISSOLUTION STUDY 


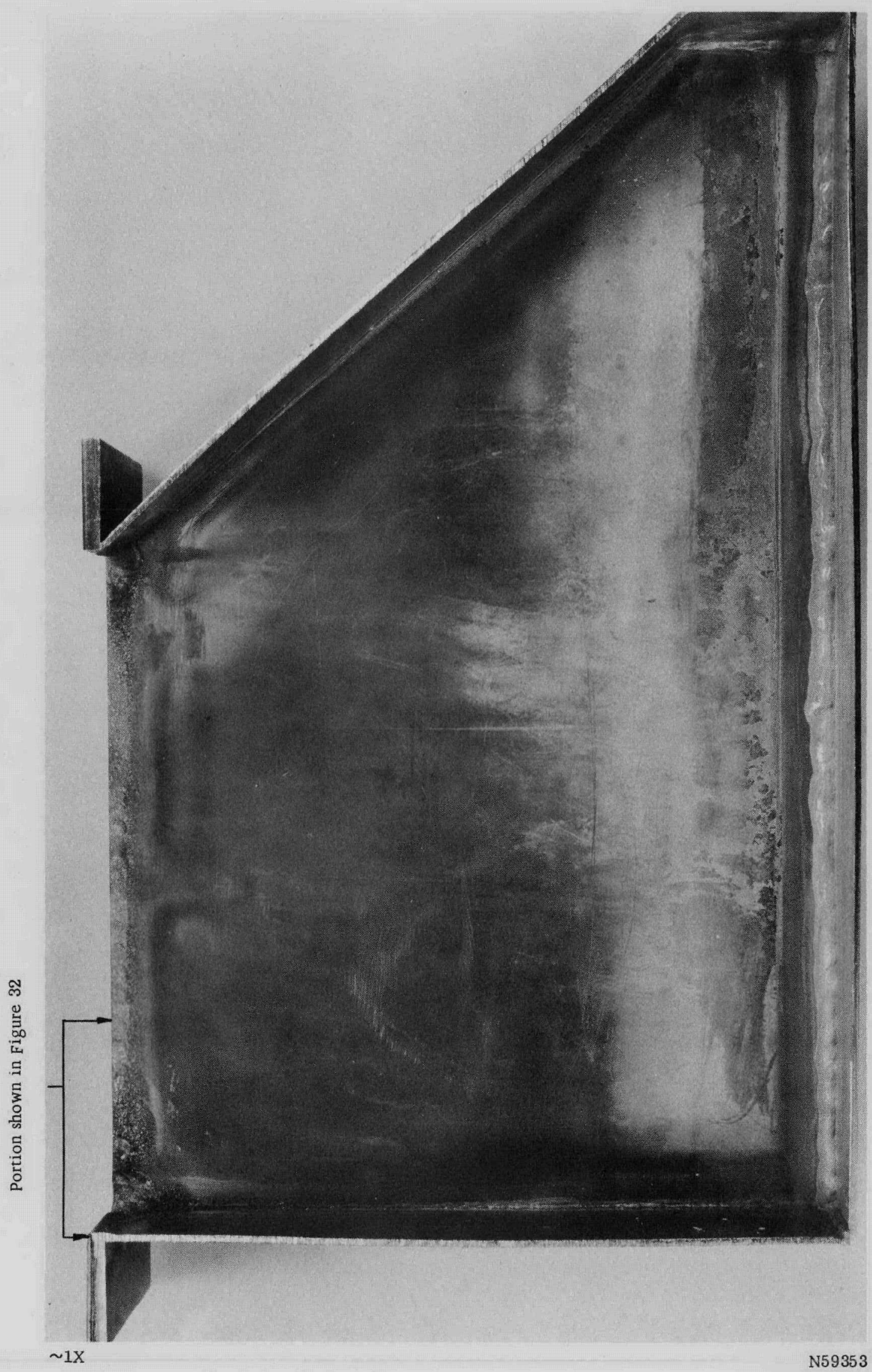

Etching around the horizontal weldments on the top flange and several liquid lines along the walls of are visible. 
thick on the submerged specimens and 0.7 to 0.8 mils thick on those exposed to the vapor. According to measurements of the sound metal remaining, some metal had been lost and corrosion rates in the range of 4 mils per month occurred on the vaporphase specimens. These values are also recorded in Table 16. Such measurements are always open to doubt because the original thickness of the titanium specimens may have varied by $1 \mathrm{mil}$, but the accuracy of the 4 -mil-per-month value should be good to about \pm 2 mils per month. Therefore, some significant corrosion can be concluded to have occurred and the gains in weight are undoubtedly attributable to the observed scale.

The total loss in weight of the dissolver, without the gasket or condenser section, was found to be $0.4 \mathrm{~g}$ out of a total of $412 \mathrm{~g}$. Based on the total inside area exposed to either liquid or vapor during the dissolution, the weight loss indicates an approximate corrosion rate of 0.2 mil per month. However, this value is probably also affected by scale formation in the same manner as the coupon-type specimens.

The dissolver and the bottom portion of the condenser were sawed in two. The two halves of the dissolver are shown in Figure 31. The etching around the horizontal weldments on the top flange is visible as are several liquid lines on the walls. Interesting areas from the horizontal weldments are shown at about $5 \mathrm{X}$ magnification in Figure 32.

Photomicrographs of a cross section taken through the horizontal weldment are shown in Figure 33. The roughening of the surface did not extend into the metal quite 1 mil. An accurate measurement of the thickness of this area prior to exposure is not available, but it appeared from measurements of the sound metal remaining that 1.5 to 2 mils of metal had been removed or damaged by attack. This would be a maximum corrosion rate of 6.5 mils per month of dis solver operation.

The weldments along the side of the vessel were not roughened. Little attack occurred on their surfaces as shown in a representative photomicrograph in Figure 34.

The vessel walls also showed negligible attack. Figure 35 shows a cross section through the wall near the bottom of the dissolver. Some of the adhering scale, which appears to be nonmetallic, is evident in this photomicrograph. Measurements of the sound metal remaining at scattered locations over the vessel walls show that, within the accuracy of the measurements, negligible corrosion occurred except at the etched areas around the top horizontal weldments.

The exposed portion of the upper flange is shown in Figure 36. The areas marked off by the gasket are visible. No significant attack occurred except around the weldment joining the condenser tube to the flange. This attack also occurred on the inside of the Titanium A-40 condenser tube. The inner surface is shown at $3 \mathrm{X}$ in Figure $37 \mathrm{a}$. A photomicrograph of a cross section through the weld is shown in Figure $37 \mathrm{~b}$. The surface roughening extended 2 to $3 \mathrm{mils}$ deep here. In addition, the tube was thinned. Whether this thinning was due to corrosion or to reduction in thickness of the tube during welding is difficult to establish. In any event, the most aggressive attack observed was in this portion. The remainder of the condenser tube seemed to be free of attack, so it was concluded that the attack was associated with the weldment and its attendant stresses. This may be similar to the attack observed at stressed areas on the coupon-type specimens exposed to chloride-contaminated Thorex solutions. 


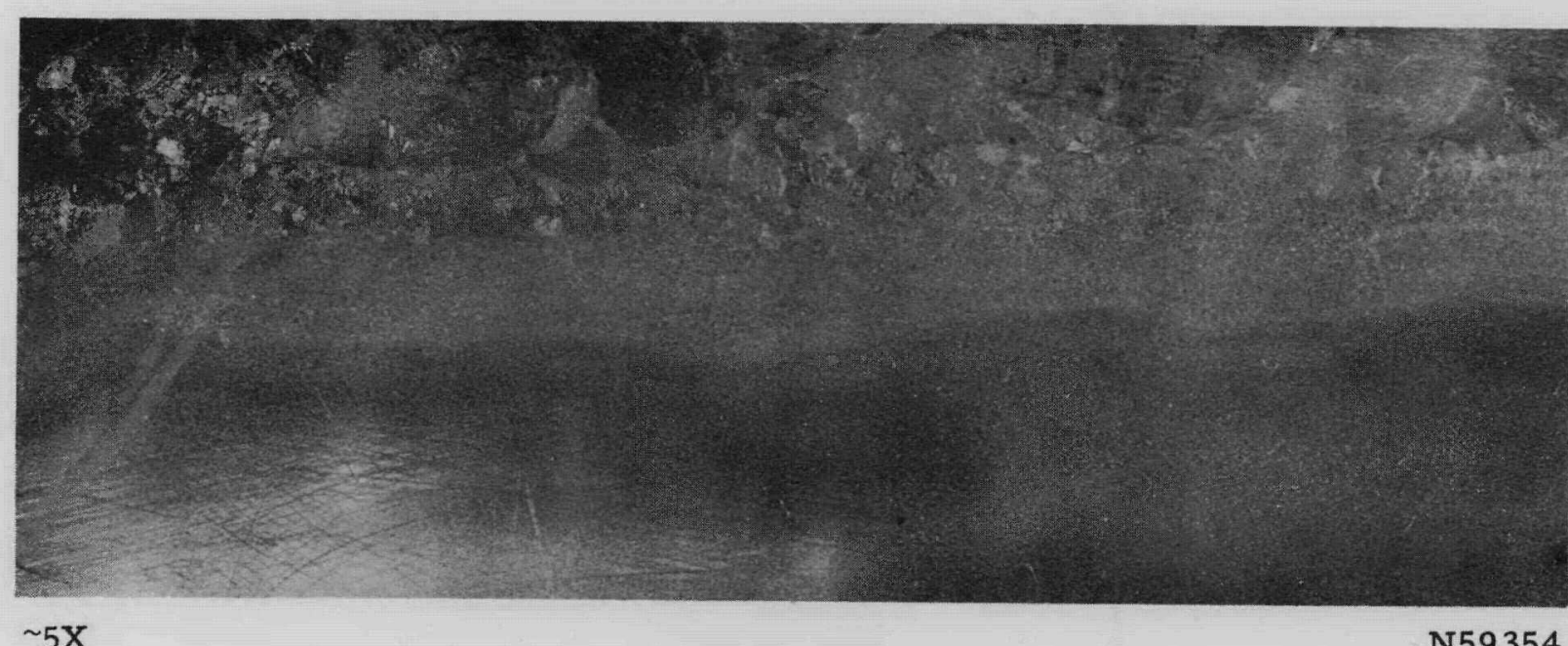

a. From Half of Dissolver Shown at the Left in Figure 31

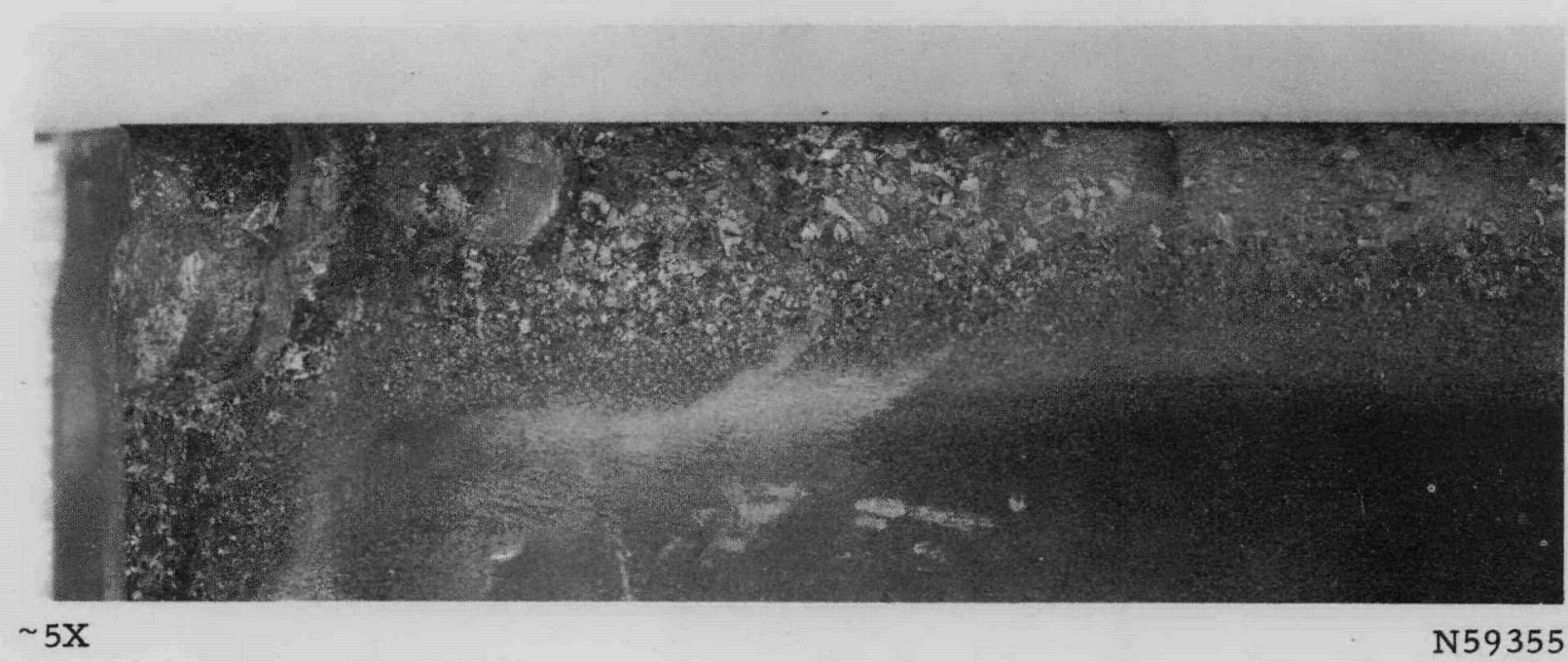

b. From Half of Dissolver Shown at the Right in Figure 31

FIGURE 32. MAGNIFIED PORTIONS OF TOP HORIZONTAL WELDMENTS FROM TITANIUM 75A DISSOLVER SHOWING ETCHING WHICH OCCURRED 


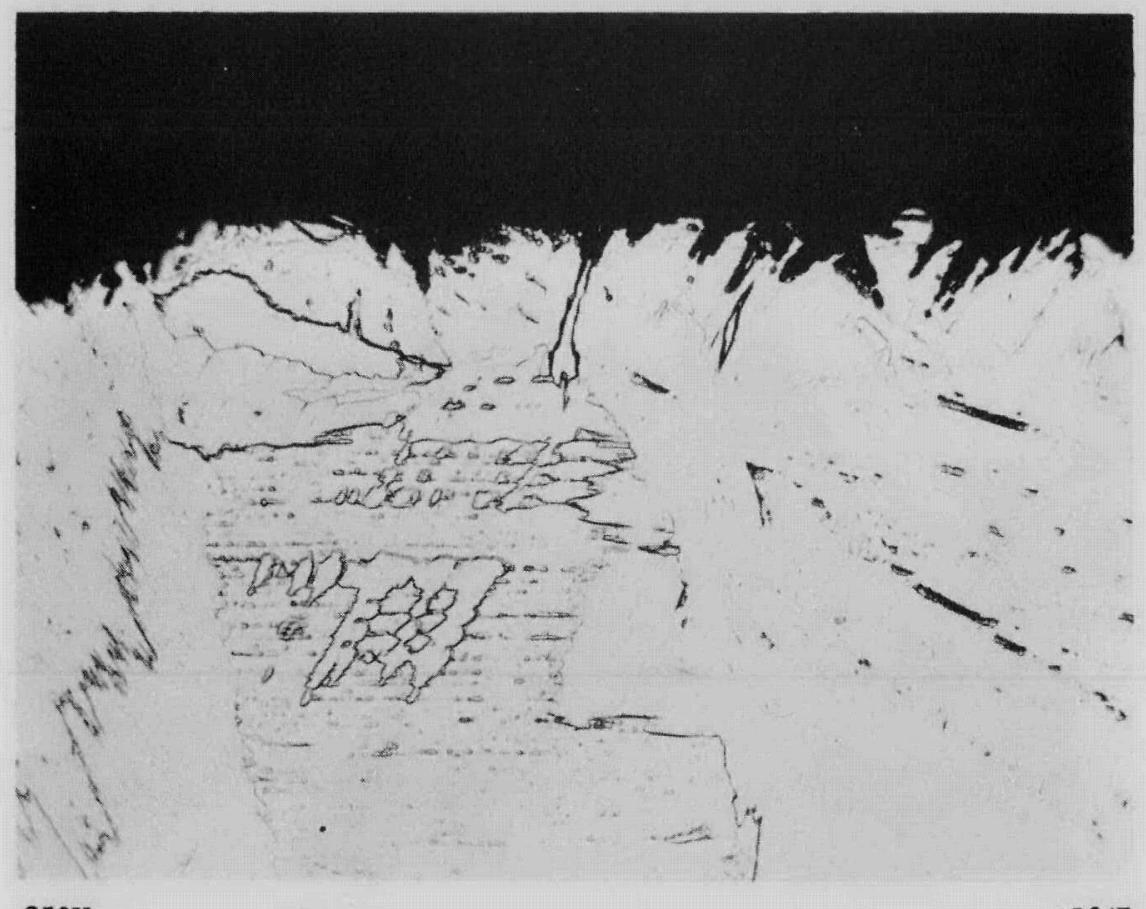

a. Weldment

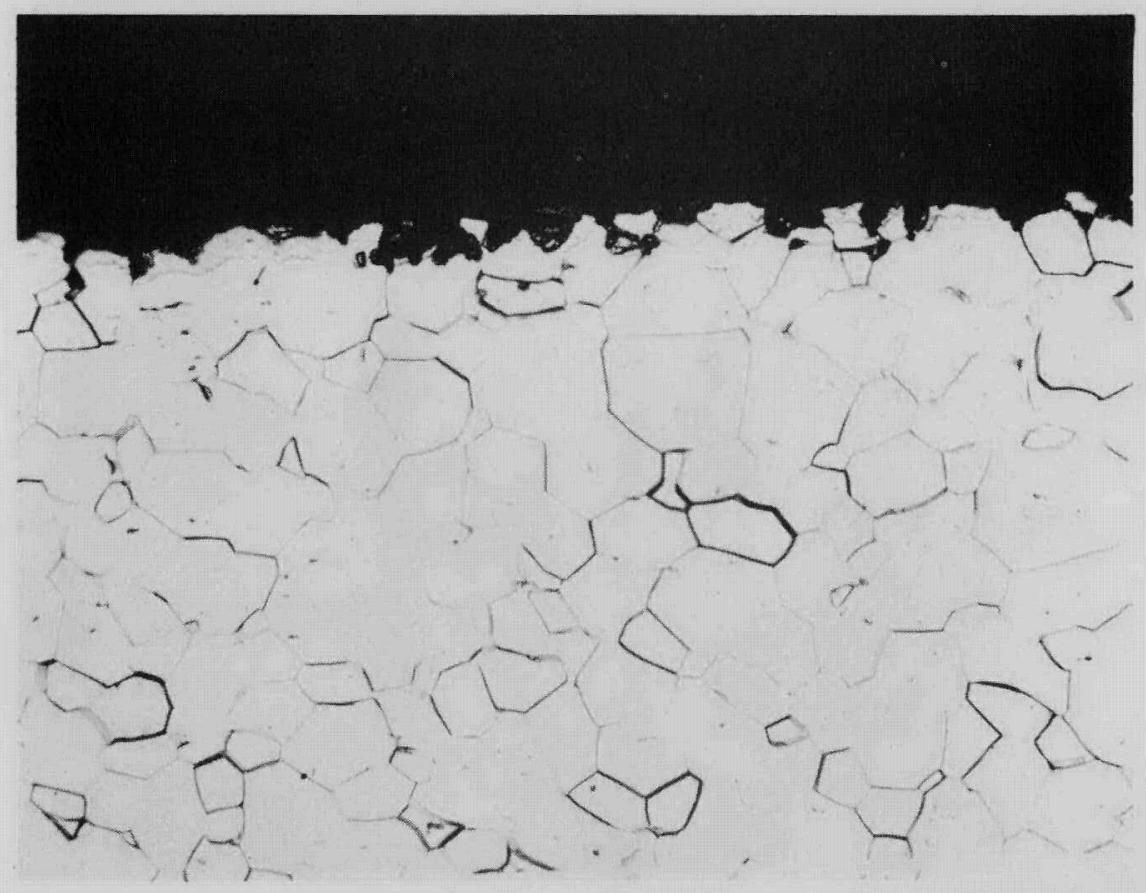

\section{b. Heat-Affected Area}

FIGURE 33. CROSS SECTIONS THROUGH ETCHED AREA OF TOP HORIZONTAL WELDMENT AND PARENT METAL OF TITANIUM 75 A DISSOLVER

The roughening of the surface did not extend into the metal quite $1 \mathrm{mil}$. 


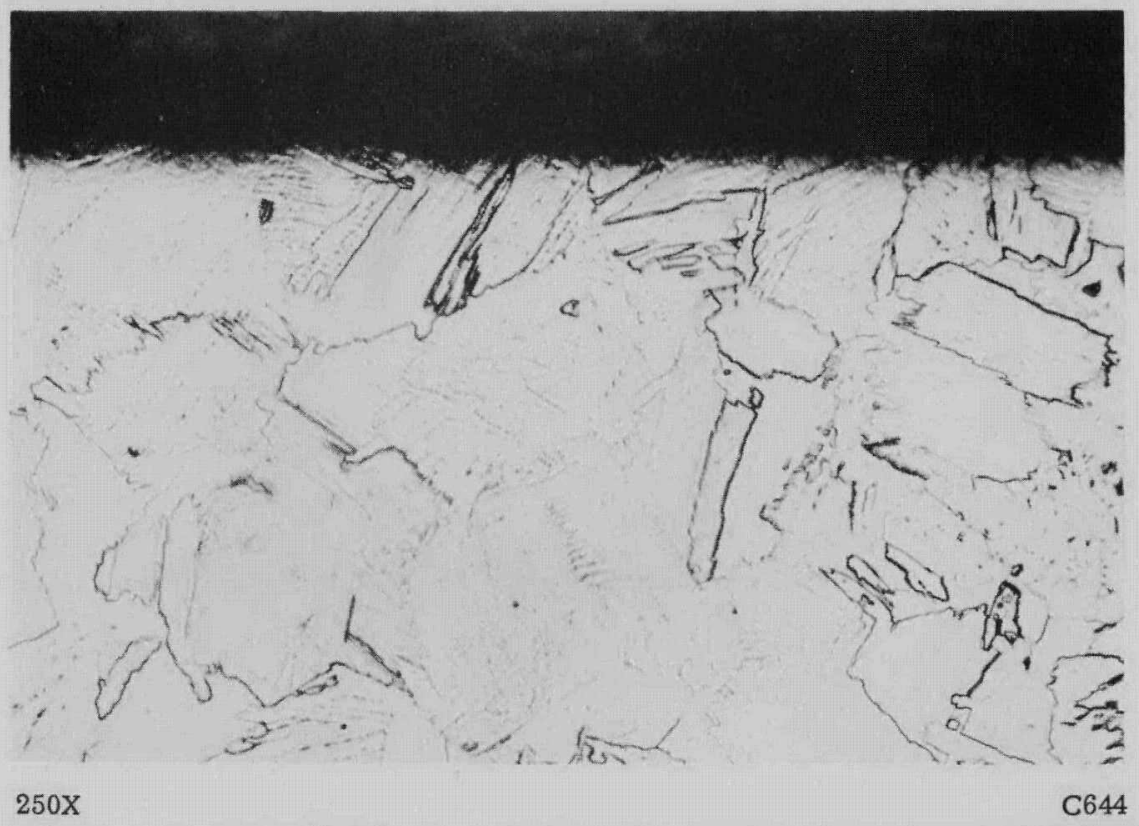

FIGURE 34. CROSS SECTION THROUGH A VERTICAL WELDMENT OF THE TITANIUM 75A DISSOLVER Little attack occurred along vertical weldments.

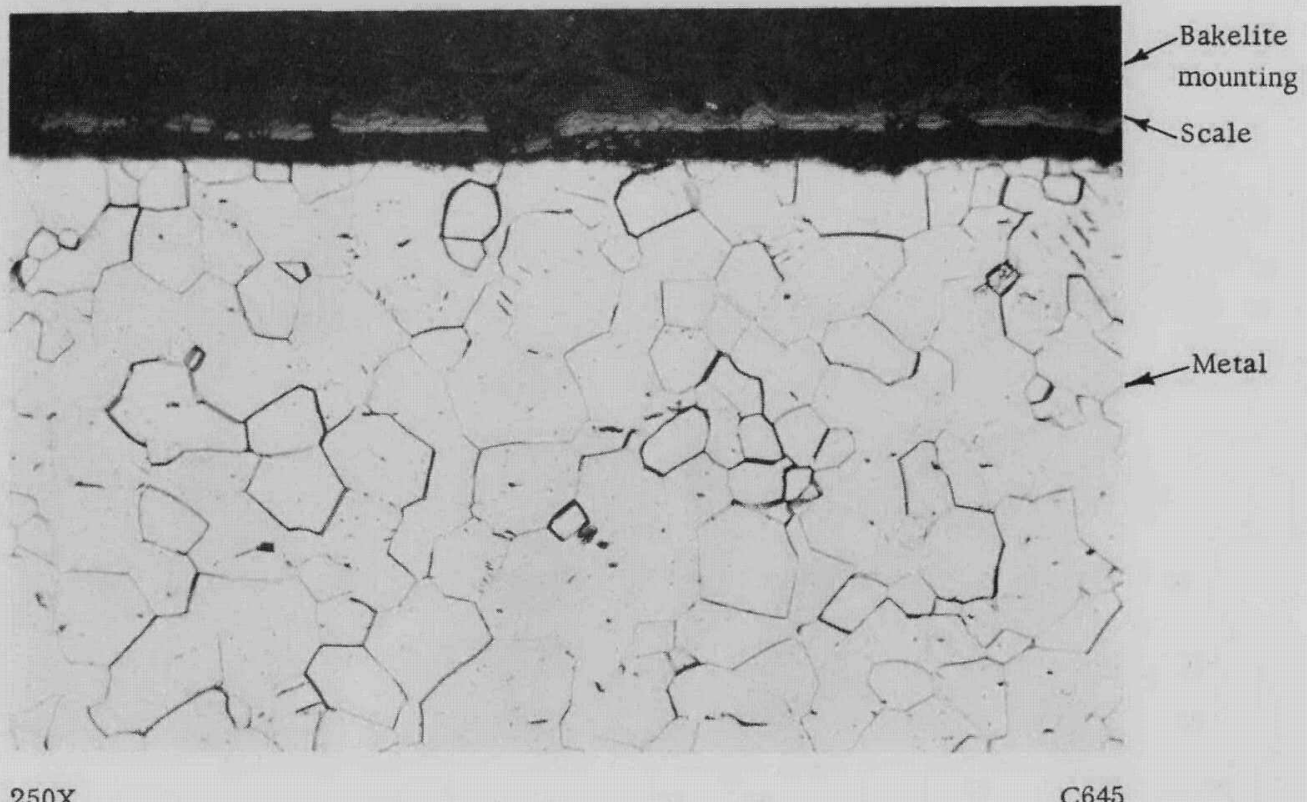

FIGURE 35. CROSS SECTION THROUGH SUBMERGED WALL OF TITANIUM 75A DISSOLVER

Attack was negligible on the vessel walls. An adherent scale, probably nonmetallic, formed on the wall surface. 


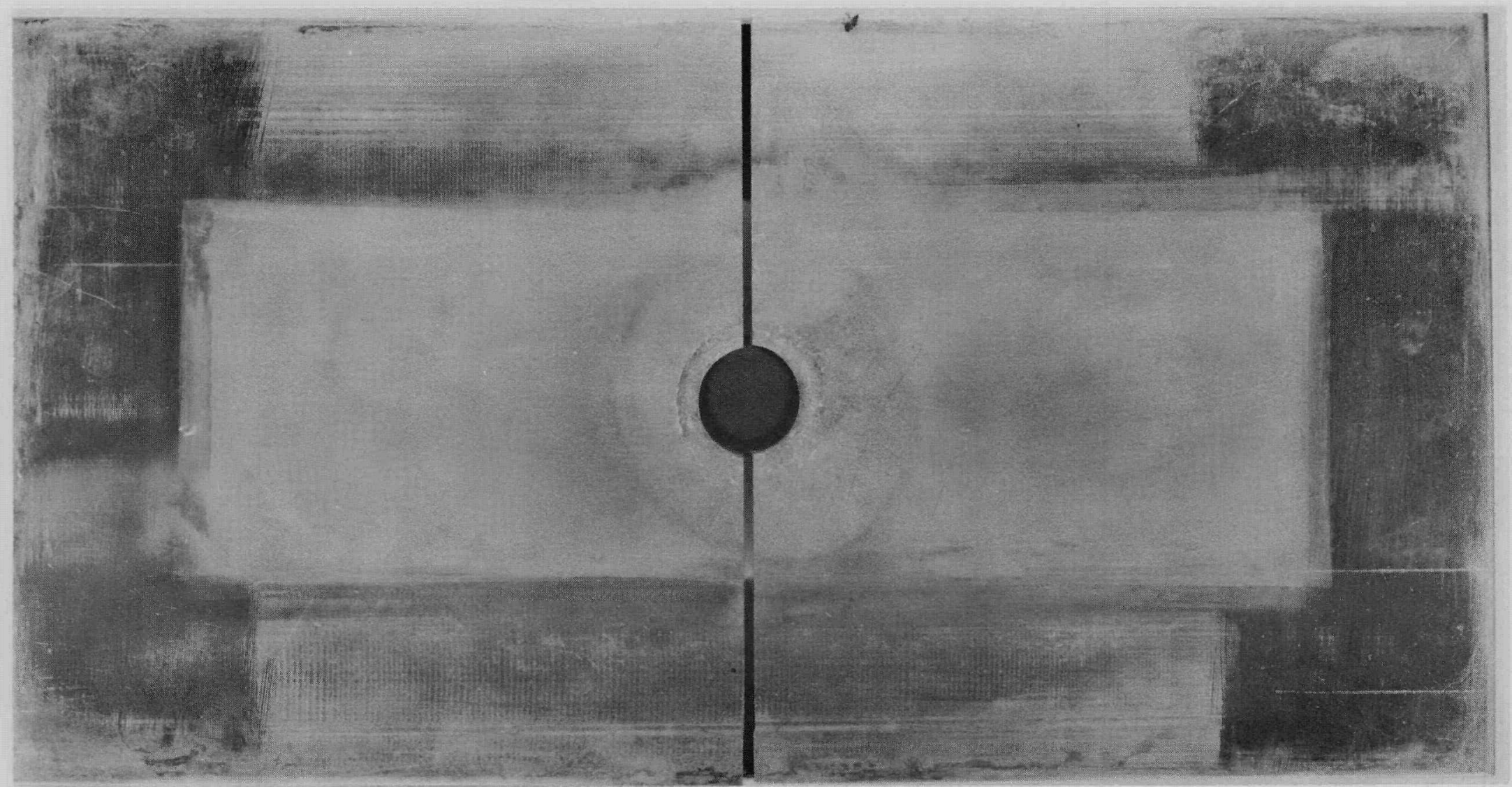

$\sim 1.5 \mathrm{X}$

N59356

FIGURE 36. EXPOSED SIDE OF TOP FLANGE FROM TITANIUM 75A CONDENSER SHOWING ETCHED AREA AROUND WELDMENT

No significant attack occurred at areas other than around the weldment. 


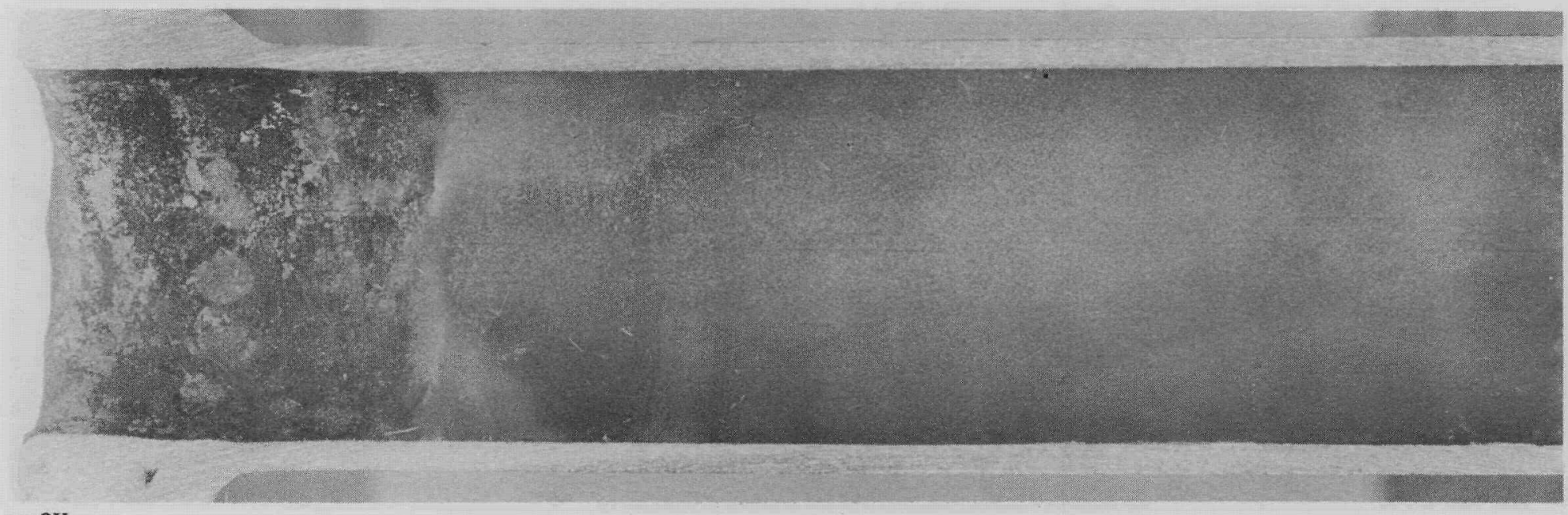

a. Extent of Attacked Area at Bottom of Titanium A-40 Condenser Tube

b. (Right). Severe Etching at Weldment Between Titanium A-40 Condenser Tube and Upper Flange of Titanium 75A Dissolver

FIGURE 37. LONGITUDINAL SECTIONS THROUGH TIT ANIUM A-40 CONDENSER TUBE AT JUNCTION WITH TOP FLANGE OF TIT ANIUM 75 A DISSOLVER

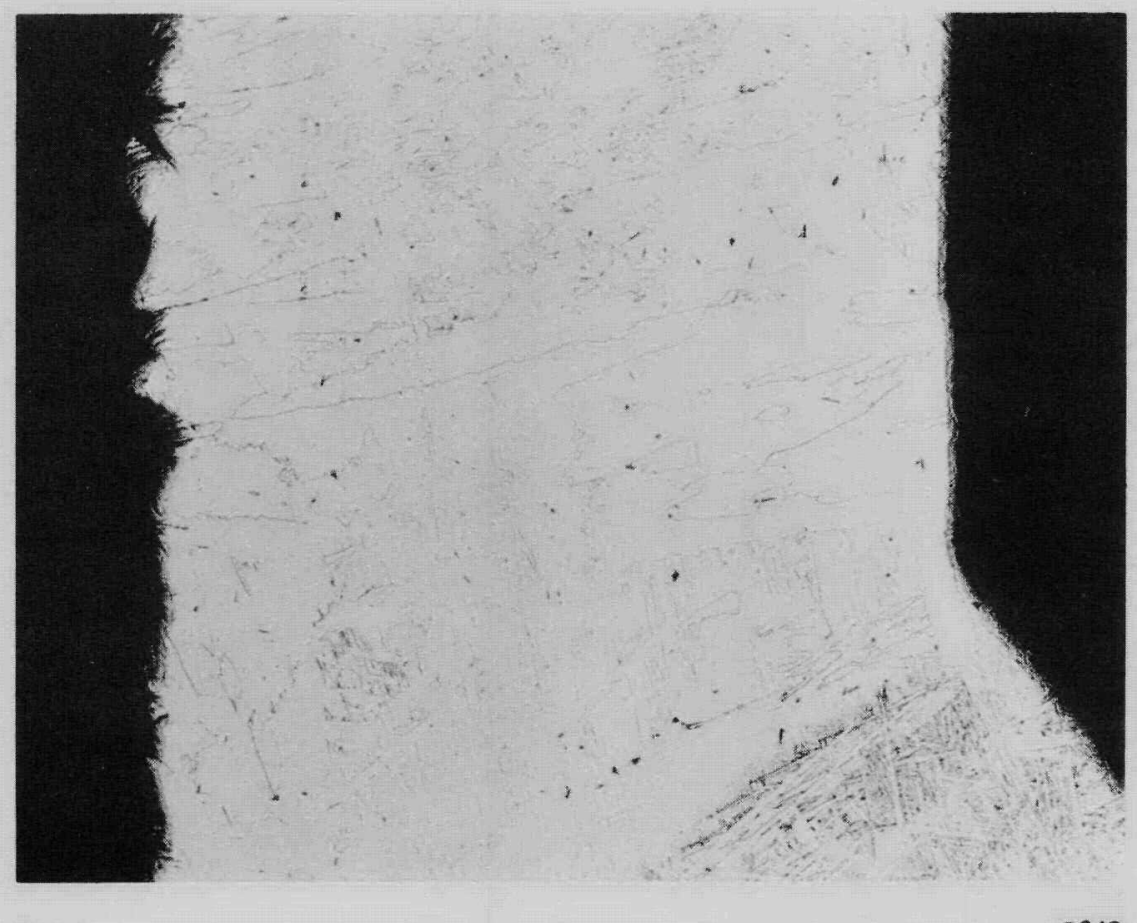

C648 
In summary, the Titanium 75A dissolver showed negligible attack from DarexThorex dissolutions except in two areas. Both areas involved weldments in the vapor phase. The attack consisted of etching on the weld and surrounding heat-affected areas. In turn, both of these weldments involved joining either the thinner wall or condenser-tube material to the heavier flanges. Precautions were taken during welding to avoid contamination of these welds, but it is the consensus of BMI welding experts that these were not good weldments. (8)

Undoubtedly these areas were attacked. However, there are several questionable circumstances connected with the location of this attack. The possibility of weld contamination has already been mentioned. In addition, during the first few dissolutions, a polyethylene gasket was used. This gasket did not withstand the temperature of the dissolutions and apparently decomposed to some extent, resulting in a greasy coating on the inside of the condenser. This was removed with solvent and a Teflon gasket was used for the remaining dissolutions without any difficulties. What effect this polyethylene gasket may have exerted on the attack of these weldments is not known.

The scouting experiments with chloride- and fluoride-contaminated Thorex solutions showed that some attack is to be expected in the vapor phase. It may be that, since the welds which were attacked were highest in the vapor zone of the apparatus, conditions were favorable in these zones for condensation and concentration of fluorides or chlorides. However, the attack observed on the weldments of the dissolver occurred at a much higher rate than was observed during the scouting tests.

Since vertical weldments in juxtaposition with the horizontal weldments show practically no attack, the favored explanation is that these horizontal weldments were contaminated in some manner.

This experiment indicates that careful attention must be given to weldments in a titanium dissolver. It also indicates that a similar experiment in a vessel fabricated with carefully prepared weldments should be made for a considerably longer period in order that the seriousness of this vapor-phase attack can be better evaluated.

\section{THE ZIRFLEX PROCESS}

The Zirflex process has been proposed for the recovery of uranium oxide fuel elements clad with zirconium or Zircaloy. In this process, the zirconium cladding is dissolved by a boiling aqueous solution of $6 \mathrm{M} \mathrm{NH} 4 \mathrm{~F}$ and $1 \mathrm{M} \mathrm{NH}_{4} \mathrm{NO}_{3}$. The ammonium nitrate is added to suppress hydrogen formation and to aid in dissolving the tin from Zircaloy. Core dissolution is then accomplished with a boiling solution of $10 \mathrm{M} \mathrm{HNO}_{3}$, $0.05 \mathrm{M} \mathrm{HF}$, and $0.02 \mathrm{M} \mathrm{Al}^{+3}$.

Research on this process was carried no further than a series of scouting studies for selecting metals to be further evaluated as container materials.

The scouting studies were conducted in reflux units consisting of Kel-F bottles topped by water-jacketed Teflon condensers. Small coupons of the metals, many containing weldments, were suspended on Teflon hooks in these bottles so that exposure occurred to the liquid and vapor phases and at the interface between. 
Three solutions were used for the first studies. One of these represented a beginning composition of the decladding step, being $6.0 \mathrm{M} \mathrm{NH}_{4} \mathrm{~F}, 1.0 \mathrm{M} \mathrm{NH}_{4} \mathrm{NO}_{3}$. The other two represented beginning and final stages in the core-dissolution process. The beginning solution was $10.05 \mathrm{M} \mathrm{H}^{+}, 10.10 \mathrm{M} \mathrm{NO}_{3}^{-}, 0.05 \mathrm{M} \mathrm{F}^{-}, 0.01 \mathrm{M} \mathrm{Zr}^{+4}$, and $0.02 \mathrm{M} \mathrm{Al}^{+3}$. The final solution was $3.05 \mathrm{M} \mathrm{H}^{+}, 5.71 \mathrm{M} \mathrm{NO}_{3}^{-}, 0.05 \mathrm{M} \mathrm{F}^{-}, 1.30 \mathrm{M}$ $\mathrm{UO}_{2}^{++}, 0.01 \mathrm{M} \mathrm{Zr}^{+4}, 0.002 \mathrm{M} \mathrm{Sn}^{+4}$, and $0.02 \mathrm{M} \mathrm{Al}^{+3}$. It soon became apparent that the final solution was not very corrosive, so the bulk of the scouting studies were conducted using only the two solutions representing beginning conditions of the decladding and core-dissolution steps. Three 24-hr-exposure periods were used with fresh solutions for each period. The results of these studies are shown in Table 17.

The data indicate that the beginning decladding solution is the most corrosive of the three used. The beginning core-dissolution solution would probably be less corrosive if its aluminum content were increased. In most cases, the corrosion rates tend to decrease upon continued exposure, and, generally, the greatest attack occurs on submerged specimens. The $72-\mathrm{hr}$ corrosion rates for the materials are compared graphically in Figure 38.

Haynes 21 was the most resistant material evaluated. This alloy is sold in cast form, but these particular specimens were cut from plate which had been rolled at BMI. Other materials which warrant further investigation, either because of their ready availability or because process vessels of these materials may have been constructed for other purposes, are Type 309, Carpenter $20 \mathrm{Cb}$, and Ni-o-nel stainless steels.

Both beginning solutions produced intergranular attack on Ni-o-nel, while the beginning core-dissolution solution also caused intergranular attack of Type 347 and Carpenter $20 \mathrm{Cb}$ alloys. Attack on the other specimens varied from general over the surface to some etching. Light pitting attack occurred on as-received Type 309 and Type 319L stainless steels.

The Hastelloy $F$ which was evaluated was not the vacuum-melted, extra-lowcarbon type which HAPO has reported promising for the Zirflex process. (9)

While conducting similar evaluations at HAPO, the investigators observed an increase of a magnitude, or more, in corrosion rates when Teflon was substituted for glass in the construction of apparatus. (10) A possible explanation seemed to lie in corrosion inhibition in the glassware experiments by some component of the borosilicate glass. In the present work, Ni-o-nel and Type 309S Cb specimens were exposed to boiling solutions of the beginning decladding composition to which boron and silicon compounds were added as possible corrosion inhibitors. The corrosion rates for these evaluations are grouped in Table 18 with those from Ni-o-nel and Type 309 stainless steels in uninhibited solutions for the purpose of comparing the effectiveness of the additives as inhibitors.

It can be seen that some inhibition occurred. However, it was only of the order of 30 to 50 per cent reduction of the attack.

Slight intergranular attack was observed on $\mathrm{Ni-o-nel} \mathrm{specimens} \mathrm{regardless} \mathrm{of} \mathrm{the}$ presence of the additive. In the presence of additives, the submerged surfaces of $\mathrm{Ni}-\mathrm{o}-\mathrm{nel}$ became slightly roughened. Light pitting occurred on Types 309 and $309 \mathrm{~S} \mathrm{Cb}$ 
TABLE 17. RESULTS OF SCOUTING EVALUATIONS OF MATERIALS IN BOILING ZIRFLEX DISSOLVER SOLUTIONS

\begin{tabular}{|c|c|c|c|c|c|c|c|c|c|c|}
\hline \multirow[b]{3}{*}{ Specimen } & \multirow{3}{*}{$\begin{array}{l}\text { Specimen } \\
\text { Position }\end{array}$} & \multicolumn{9}{|c|}{ Corrosion Rate in Solution (a) Shown, mils per month } \\
\hline & & \multicolumn{3}{|c|}{ Beginning Decladding } & \multicolumn{3}{|c|}{ Beginning Core Dissolution } & \multicolumn{3}{|c|}{ Final Core Dissolution } \\
\hline & & $24 \mathrm{Hr}$ & $48 \mathrm{Hr}$ & $72 \mathrm{Hr}$ & $24 \mathrm{Hr}$ & $48 \mathrm{Hr}$ & $72 \mathrm{Hr}$ & $24 \mathrm{Hr}$ & $48 \mathrm{Hr}$ & $72 \mathrm{Hr}$ \\
\hline \multirow{3}{*}{$\begin{array}{l}\text { Type } 304 \text { ELC } \\
\text { (as welded) }\end{array}$} & Vapor & 0.00 & 0.00 & $g^{(b)}$ & 5.1 & 4.3 & 4.2 & 0.39 & 0.24 & 0.24 \\
\hline & Interface & 17 & 14 & 15 & 5.6 & 5.0 & 5.1 & 0.71 & 0.55 & 0.53 \\
\hline & Liquid & 20 & 19 & 20 & 5.7 & 5.4 & 5.4 & 0.55 & 0.58 & 0.54 \\
\hline \multirow{3}{*}{$\begin{array}{l}\text { Type } 347 \text { (as } \\
\text { welded) }\end{array}$} & Vapor & 0.14 & 0.08 & 0.05 & 3.5 & 3.7 & 3.8 & 0.39 & 0.32 & 0.28 \\
\hline & Interface & 5.3 & 6,5 & 7.6 & 5.7 & 5.3 & 5.3 & 0.68 & 0.48 & 0.40 \\
\hline & Liquid & 6.6 & 9.5 & 12 & 5.8 & 5.5 & 5.5 & 0.79 & 0.56 & 0.47 \\
\hline \multirow{3}{*}{$\begin{array}{c}\text { Carpenter } 20 \mathrm{Cb} \\
\text { (as welded) }\end{array}$} & Vapor & 0.20 & 0.38 & 0.26 & 5.1 & 4.6 & 3.4 & 0.64 & 0.45 & 0.33 \\
\hline & Interface & 9.2 & 8.0 & 8.1 & 6.0 & 5.2 & 5.0 & 1.1 & 0.82 & 0.68 \\
\hline & Liquid & 9.1 & 8.9 & 8.8 & 6.2 & 5.4 & 5.1 & 1.1 & 0.83 & 0.69 \\
\hline \multirow{3}{*}{$\begin{array}{l}\text { Ni-o-nel } \\
\text { (welded and } \\
\text { heat treated)(c) }\end{array}$} & Vapor & 0.04 & 0.03 & 0.02 & 2.1 & 2.3 & 2.4 & 0.19 & 0.22 & 0.19 \\
\hline & Interface & 9.9 & 9.9 & 9.6 & 3.6 & 3.6 & 3.8 & 0.25 & 0.27 & 0.26 \\
\hline & Liquid & 12 & 12 & 12 & 3.4 & 3.2 & 3.3 & 0.32 & 0.30 & 0.29 \\
\hline \multirow{3}{*}{$\begin{array}{l}\mathrm{Ni}-\mathrm{o}-\mathrm{nel} \\
\text { (as welded) }\end{array}$} & Vapor & 0.04 & 0.02 & 0.01 & -- & -. & -. & & & \\
\hline & Interface & 11 & 7.4 & 8.1 & -. & -. & - & & & \\
\hline & Liquid & 10 & 9.7 & 9.4 & $\cdots$ & - & - & & & \\
\hline \multirow{3}{*}{$\begin{array}{l}\text { Type } 309 \\
\text { (as received) }\end{array}$} & Vapor & 0.02 & 0.01 & 0.00 & 2.6 & 2.2 & 1.9 & & & \\
\hline & Interface & 6.8 & 5.9 & 5.5 & 3.0 & 2.5 & 2.3 & & & \\
\hline & Líquid & 7.8 & 7.1 & 7.2 & 3.3 & 2.6 & 2.4 & & & \\
\hline \multirow{3}{*}{$\begin{array}{l}\text { Type } 309 \text { (heat } \\
\text { treated)(d) }\end{array}$} & Vapor & 0.55 & 0.52 & 0.34 & 3.4 & 3.1 & 2.7 & & & \\
\hline & Interface & 4.7 & 5.3 & 5.4 & 2.9 & 2.5 & 2.3 & & & \\
\hline & Liquid & 6.5 & 6.3 & 6.4 & 2.5 & 2.1 & 2.0 & & & \\
\hline \multirow{3}{*}{$\begin{array}{l}\text { Type } 309 \mathrm{Cb} \\
\text { (welded tubing) }\end{array}$} & Vapor & 0.00 & 0.09 & 0.06 & 2.9 & 2.9 & 2.7 & & & \\
\hline & Interface & 4.7 & 5.2 & 4.9 & 4.1 & 3.7 & 3.7 & & & \\
\hline & Liquid & 8.6 & 8.3 & 8.5 & 3.7 & 3.5 & 3.4 & & & \\
\hline \multirow{3}{*}{$\begin{array}{l}\text { Type } 316 \\
\text { (welded tubing) }\end{array}$} & Vapor & 0.00 & 0.05 & 0.02 & 5.7 & 3.3 & 2.5 & & & \\
\hline & Interface & 9.3 & 9.4 & 8.8 & 5.8 & 3.9 & 3.6 & & & \\
\hline & Liquid & 18 & 15 & 15 & 4.4 & 4.1 & 4.0 & & & \\
\hline \multirow{3}{*}{$\begin{array}{l}\text { Type } 319 \mathrm{~L} \\
\text { (welded tubing) }\end{array}$} & Vapor & 4.8 & 2.3 & 1.7 & 4.8 & 4.9 & 5.1 & & & \\
\hline & Interface & 28 & 28 & 27 & 5.7 & 5.3 & 5.2 & & & \\
\hline & Liquid & 29 & 28 & 27 & 5.5 & 5.2 & 5.1 & & & \\
\hline \multirow{3}{*}{$\begin{array}{l}\text { Haynes } 21 \text { (as } \\
\text { rolled at } \\
\text { BMI) }\end{array}$} & Vapor & 0.04 & 0.02 & 0.02 & 2.2 & 1.8 & 1.7 & & & \\
\hline & Interface & 1.7 & 1.5 & 1.6 & 3.3 & 3.0 & 3.0 & & & \\
\hline & Liquid & 2.8 & 2.4 & 2.3 & 3.3 & 2.9 & 2.8 & & & \\
\hline \multirow{3}{*}{$\begin{array}{l}\text { Haynes } 25 \\
\text { (as received) }\end{array}$} & Vapor & $g$ & 0.11 & -. & 6.1 & 5.4 & 5.1 & & & \\
\hline & Interface & 9.7 & 9.6 & -- & 7.4 & 6.6 & 6.1 & & & \\
\hline & Liquid & 12 & 11 & - & 6.9 & 6.2 & 5.9 & & & \\
\hline
\end{tabular}


TABLE 17. (Continued)

\begin{tabular}{|c|c|c|c|c|c|c|c|c|c|c|}
\hline \multirow[b]{3}{*}{ Specimen } & \multirow{3}{*}{$\begin{array}{c}\text { Specimen } \\
\text { Position }\end{array}$} & \multicolumn{9}{|c|}{ Corrosion Rate in Solution(a) Shown, mils per month } \\
\hline & & \multicolumn{3}{|c|}{ Beginning Decladding } & \multicolumn{3}{|c|}{ Beginning Core Dissolution } & \multicolumn{3}{|c|}{ Final Core Dissolution } \\
\hline & & $24 \mathrm{Hr}$ & $48 \mathrm{Hr}$ & $72 \mathrm{Hr}$ & $24 \mathrm{Hr}$ & $48 \mathrm{Hr}$ & $72 \mathrm{Hr}$ & $24 \mathrm{Hr}$ & $48 \mathrm{Hr}$ & $72 \mathrm{Hr}$ \\
\hline \multirow{3}{*}{$\begin{array}{l}\text { Hastelloy F } \\
\text { (as received) }\end{array}$} & Vapor & 0.11 & 2.1 & 1.6 & 12 & 6.9 & 5.4 & & & \\
\hline & Interface & 16 & 12 & 12 & 13 & 8.8 & 6.9 & & & \\
\hline & Liquid & 19 & 16 & 15 & 13 & 9.0 & 7.2 & & & \\
\hline \multirow{3}{*}{$\begin{array}{r}\text { Titanium } 75 \mathrm{~A} \\
\text { (as received) }\end{array}$} & Vapor & 8.4 & -- & - & 0.08 & 0.08 & 1.1 & & & \\
\hline & Interface & 341 & -- & -- & 3.6 & 2.5 & 2.1 & & & \\
\hline & Liquild & 419 & -- & -- & 2.5 & 2.9 & 2.3 & & & \\
\hline
\end{tabular}

(a) Compositions of Zirflex scouting solutions:

Beginning decladding $\quad 6.0 \mathrm{M} \mathrm{NH}_{4} \mathrm{~F}, 1.0 \mathrm{M} \mathrm{NH}_{4} \mathrm{NO}_{3}$

Beginning core dissolution $10.05 \mathrm{M} \mathrm{H}^{+}, 10.10 \mathrm{M} \mathrm{NO}_{3}^{-}, 0.05 \mathrm{M} \mathrm{F}^{-}, 0.01 \mathrm{M} \mathrm{Zr}^{+4}, 0.02 \mathrm{M} \mathrm{Al}^{+3}$

Final core dissolution $\quad 3.05 \mathrm{M} \mathrm{H}^{+}, 5.71 \mathrm{M} \mathrm{NO}_{3}^{-}, 1.3 \mathrm{M} \mathrm{UO}_{2}^{+}, 0.05 \mathrm{M} \mathrm{F}^{-}, 0.01 \mathrm{M} \mathrm{Zr}^{+4}, 0.002 \mathrm{M} \mathrm{Sn}^{+4}, 0.02 \mathrm{M} \mathrm{Al}^{+3}$.

(b) $\mathrm{g}$ indicates a small gain in weight.

(c) Ni-o-nel specimen heat treated after welding for $0.5 \mathrm{hr}$ at $1850 \mathrm{~F}$ and air quenched.

(d) Type 309 stainless specimen heat treated for $0.5 \mathrm{hr}$ at $1950 \mathrm{~F}$ and air quenched. 

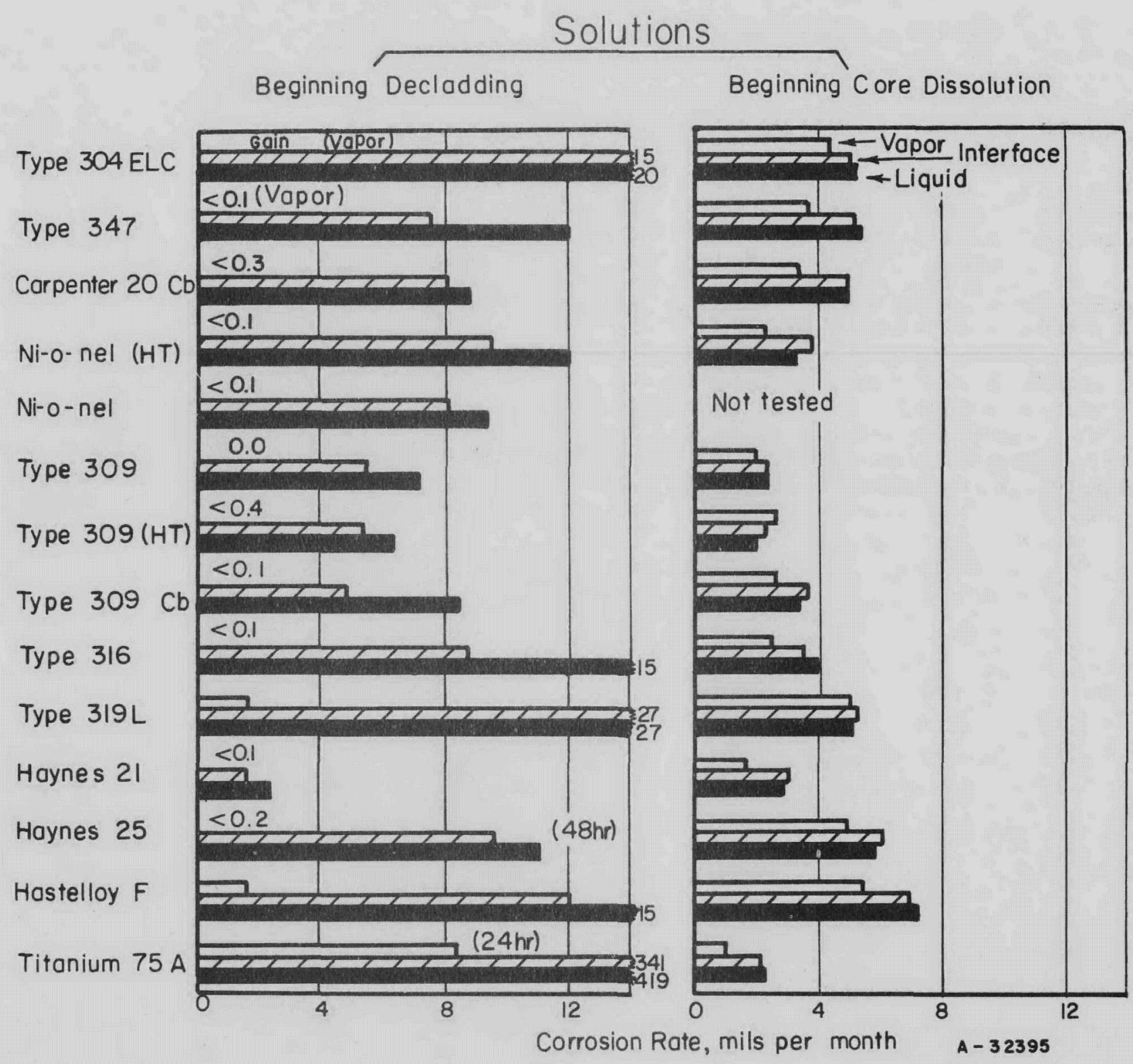

FIGURE 38. RESULTS OF SCOUTING EVALUATIONS OF MATERIALS FOR A ZIRFLEX DISSOLVER

All specimens were exposed $72 \mathrm{hr}$ except when noted. Refer to Table 17 for compositions of solutions. 
TABLE 18. RESULTS OF EVALUATION OF SILICON AND BORON AS INHIBITORS FOR BOILING ZIRF LEX (6.0 $\mathrm{M} \mathrm{NH}_{4} \mathrm{~F}$, 1. $0 \mathrm{M} \mathrm{NH}_{4} \mathrm{NO}_{3}$ ) DECLADDING SOLUTION

\begin{tabular}{|c|c|c|c|c|c|c|c|c|}
\hline \multirow[b]{2}{*}{ Specimen } & \multirow[b]{2}{*}{ Solution } & \multirow{2}{*}{$\begin{array}{c}\text { Specimen } \\
\text { Position }\end{array}$} & \multicolumn{6}{|c|}{$\begin{array}{c}\text { Corrosion Rate at Time Shown, } \\
\text { mils per month }\end{array}$} \\
\hline & & & $24 \mathrm{Hr}$ & $48 \mathrm{Hr}$ & $72 \mathrm{Hr}$ & $144 \mathrm{Hr}$ & $168 \mathrm{Hr}$ & $500 \mathrm{Hr}$ \\
\hline \multirow[t]{3}{*}{$\mathrm{Ni}-\mathrm{o}-\mathrm{ne} \mathrm{l}^{(\mathrm{a})}$} & \multirow[t]{3}{*}{ Standard } & Vapor & 0.04 & 0.03 & 0.02 & 0.03 & 0.02 & $g^{(b)}$ \\
\hline & & Interface & 9.9 & 9.9 & 9.6 & 6.6 & 6.5 & 4.5 \\
\hline & & Liquid & 12 & 12 & 12 & 10 & 10 & 7.7 \\
\hline \multirow[t]{3}{*}{$\mathrm{Ni-o-ne1^{(a) }}$} & \multirow{3}{*}{$\begin{array}{r}\text { Inhibitors } \\
\text { added }(c)\end{array}$} & Vapor & 0.24 & 0.14 & 0.15 & 0.09 & 0.08 & 0.03 \\
\hline & & Interface & 3.6 & 2.9 & 3.2 & 3.5 & 3.6 & 2. 0 \\
\hline & & Liquid & 6.6 & 5.7 & 6.0 & 6.4 & 6.7 & 6.1 \\
\hline \multirow[t]{3}{*}{ Type $309^{(d)}$} & \multirow[t]{3}{*}{ Standard } & Vapor & 0.02 & 0.01 & 0.00 & -- & -- & -- \\
\hline & & Interface & 6.8 & 5.9 & 5.5 & -- & -. & -- \\
\hline & & Liquid & 7.8 & 7.1 & 7. 2 & -- & -- & -- \\
\hline \multirow{3}{*}{ Type $309 \mathrm{~S} \mathrm{Cb}^{(\mathrm{d})}$} & \multirow{3}{*}{$\begin{array}{r}\text { Inhibitors } \\
\operatorname{added}(\mathrm{c})\end{array}$} & Vapor & 0.78 & 0.64 & 0.73 & 0.46 & 0.41 & 0.16 \\
\hline & & Interface & 3.6 & 2.6 & 2. 3 & 1.8 & 1.9 & 1. 8 \\
\hline & & Liquid & 5.3 & 4. 3 & 4. 0 & 4. 3 & 4.6 & 4. 1 \\
\hline
\end{tabular}

(a) $\mathrm{Ni}-\mathrm{o}$-nel specimens were welded from stabilized stock and then heat treated for $0.5 \mathrm{hr}$ at $1850 \mathrm{~F}$, air quenched, and surface ground prior to exposure.

(b) g indicates small gain in weight.

(c) Inhibitors added were: $0.05 \mathrm{M} \mathrm{Na}_{2} \mathrm{~B}_{4} \mathrm{O}_{7} \cdot 10 \mathrm{H}_{2} \mathrm{O}+0.05 \mathrm{M} \mathrm{Na}_{2} \mathrm{SiO}_{3} \cdot 9 \mathrm{H}_{2} \mathrm{O}$.

(d) Specimens of Types 309 and $309 \mathrm{~S} \mathrm{Cb}$ stainless steel were exposed in the as-received condition. 
stainless specimens, and the interface specimen of the latter was slightly roughened at the liquid line. All specimens were covered with a heavy bright-green scale (probably a fluoride) upon removal from the solutions. This scale turned to a dull-copper color on contact with hot water and slowly washed away.

Certainly Haynes 21, Carpenter $20 \mathrm{Cb}, \mathrm{Ni}-\mathrm{o}-\mathrm{nel}$, and Type 309 or 309S Cb alloys are worthy of further investigation for use in construction of a Zirflex dissolver. The data indicate that inhibitor systems may be found for the decladding solution. If these do not affect the decladding adversely, acceptable corrosion rates may be obtained for some or all of these materials. Presently, the rates from the scouting evaluations in decladding solution appear to be too high for use of any material except possibly Haynes 21. However, the starting solutions are usually the most corrosive. The buildup of zirconium in the solution and the probable galvanic protection from dissolving elements are expected to lower the corrosion rates. Consequently, the corrosion measured over the complete decladding process may be entirely acceptable with or without addition of inhibitors. This can only be proven by extensive evaluations of specimens in systems involving actual zirconium decladding followed by core dis solution.

\section{POSSIBLE USE OF THE SAME VESSEL FOR THE ZIRF LEX AND SULFEX-THOREX PROCESSES}

The variety of fuel elements which a plant may be called upon to process makes the possibility of finding a universal processing scheme economically attractive. As yet, no such scheme has been forthcoming. However, a reasonable savings in plant and operating costs could be realized if two processes, one usable on stainless steel cladding and the other on zirconium cladding, could be operated at different times in the same vessels. The Zirflex and Sulfex-Thorex processes were considered from this standpoint.

No experimental studies were made in which specimens were alternately exposed to conditions of each process. Such research was planned for a later stage. However, five materials were evaluated by scouting experiments in solutions from each process. The results of these studies, which have been reported separately in their respective sections, are shown graphically for comparison in Figure 39.

It can be seen that, of the materials evaluated, only Carpenter $20 \mathrm{Cb}$ and $\mathrm{Ni}-\mathrm{o}-\mathrm{nel}$ show promise in both systems. The other materials are eliminated by their lack of resistance to boiling $6 \mathrm{M} \mathrm{H}_{2} \mathrm{SO}_{4}$. However, it should be emphasized that these evaluations are only of a very preliminary nature. Many other materials should be scouted in both systems and considerably more complete studies of Ni-o-nel and Carpenter $20 \mathrm{Cb}$ must be conducted before any recommendations can be made. 


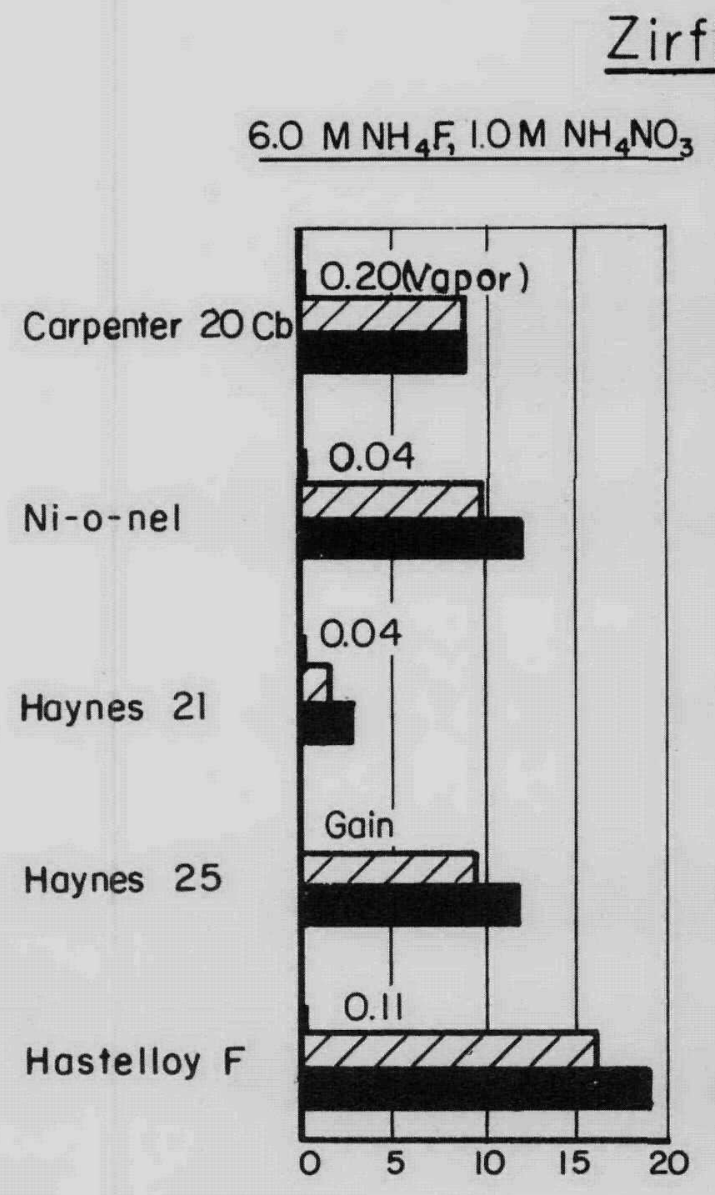

\section{Zirflex}

$0.0 \mathrm{M} \mathrm{HNO}_{3}, 0.05 \mathrm{M} \mathrm{HF}_{1}$
$0.01 \mathrm{M} \mathrm{Zr}^{+4} 0.02 \mathrm{M} \mathrm{Al}^{+3}$

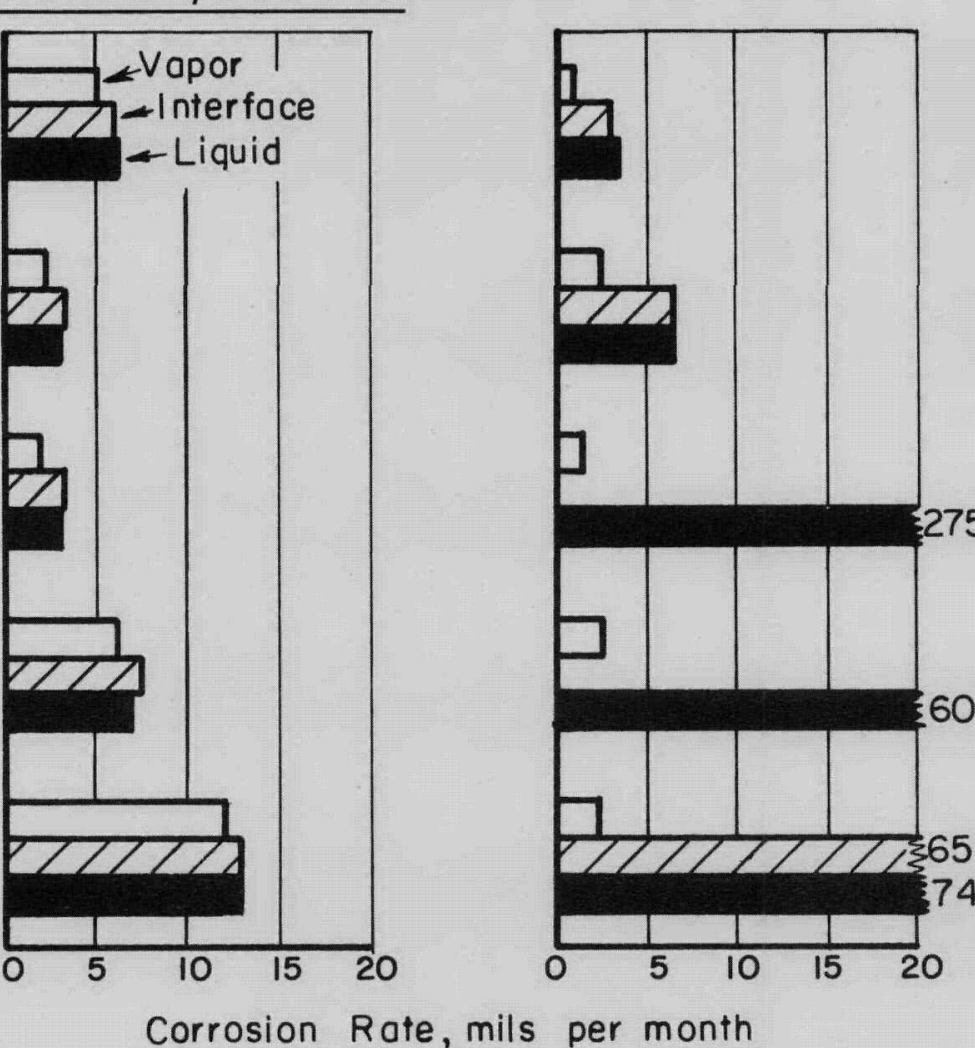

\section{Sulfex-Thorex}

\section{$6.0 \mathrm{M} \mathrm{H}_{2} \mathrm{SO}_{4} \quad 13.0 \mathrm{M} \mathrm{HNO}_{3}, 0.05 \mathrm{M} \mathrm{F}^{-} \mathrm{O}_{2} \mathrm{M} \mathrm{Al}^{+3}$}

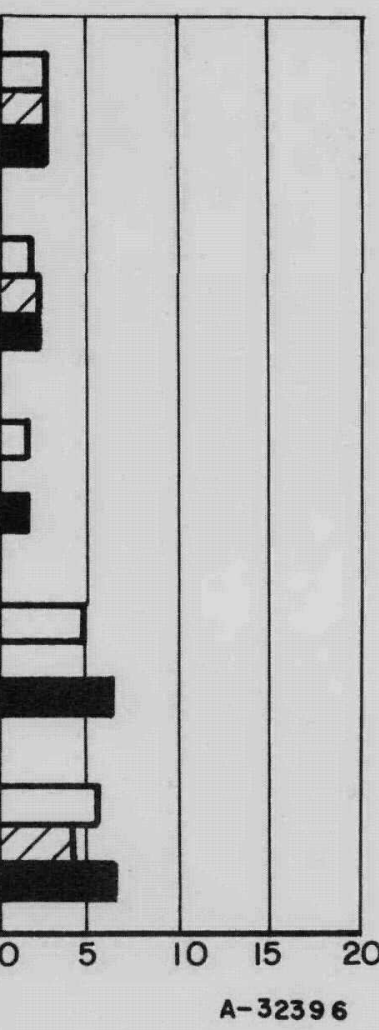

FIGURE 39. COMPARISON OF RESULTS OF 24-HR SCOUTING EVALUATIONS OF CONTAINER MATERIALS FOR THE ZIRFLEX AND SULFEX-THOREX PROCESSES 


\section{THE ZIRCEX PROCESS}

Zirconium fuels may be recovered by the Zircex process. In this operation, the fuels are subjected to dry hydrogen chloride at 400 to $600 \mathrm{C}$, the volatile zirconium tetrachloride is distilled off, and the uranium-containing residue is dissolved in nitric acid.

The evaluation program for materials of construction for the Zircex hydrochlorinator-dissolver was reported in BMI-1242. (1) Certain data from that study were not available at the time of writing that report and are presented herein.

A group of materials was exposed only to the hot cycle (the hydrochlorination). All of the specimens showed a certain amount of scale formation and all except Type S-590 gained in weight during the exposure (see Table 5 of BMI-1242). These specimens were exposed for an additional 15 cycles, making a total of 75 cycles, weighed, and examined metallographically. Table 19 summarizes the results obtained. It can be seen that none of the materials showed excessively high corrosion rates. No attack occurred on Illium R, Hastelloy C, or nickel. Only slight attack was found on Inconel and Type S-816. These materials should be considered if the Zircex process is operated with separate vessels for the hydrochlorination and dissolution, or if the dissolution conditions are made less corrosive.

TABLE 19. RESULTS OF ZIRCEX CYCLIC TESTS

Data are for hot cycle only.

\begin{tabular}{|c|c|c|c|}
\hline \multirow[b]{2}{*}{$\begin{array}{l}\text { Specimen } \\
\text { Material } \\
\end{array}$} & \multicolumn{2}{|c|}{75 Cycles } & \multirow[b]{2}{*}{$\begin{array}{c}\text { Remarks Based on } \\
\text { Metallographic Examination }\end{array}$} \\
\hline & $\begin{array}{c}\text { Weight Change, } \\
\text { mg }\end{array}$ & $\begin{array}{l}\text { Corrosion Rate } \\
\text { by Metallography, } \\
\text { mils per } 100 \text { cycles }\end{array}$ & \\
\hline Haynes 25 & Gain 2 & 2. 1 & General attack \\
\hline Type S-816 & Gain 39 & 0.5 & Slight intergranular attack \\
\hline Type $S-590$ & Loss $133(a)$ & 2. 0 & Severe intergranular attack \\
\hline Inconel & Gain 67 & 0.0 & Slight surface attack \\
\hline Illium R & Gain 46 & 0.5 & No attack \\
\hline Hastelloy B & Gain 157 & 1.1 & Slight intergranular attack \\
\hline Hastelloy C & Gain 70 & 0.0 & No attack \\
\hline Nickel & Gain 95 & $\begin{array}{r}\text { Dimensional } \\
\text { increase(b) }\end{array}$ & No attack \\
\hline
\end{tabular}

(a) Weight change corresponding to rate of $0.3 \mathrm{mil}$ per 100 cycles.

(b) Possibly due to plastic flow of metal during polishing. 


\title{
THE DAREX PROCESS
}

\author{
Dissolver Studies
}

The Darex process uses a mixture of hydrochloric and nitric acids (dilute aqua regia) to dissolve fuel elements containing stainless steel as a diluent or cladding. BMI- $1242(1)$ indicated that titanium was the most promising of the materials evaluated. Accordingly, more extensive and complete studies of titanium under a variety of conditions have been made and the results are presented herein.

The report referred to above discussed exposure studies made in the presence of dissolving stainless steel in a flowing dissolver. The same equipment was used to evaluate welded specimens of Titanium 55A supplied by ORNL. The welds were prepared under field service conditions. The specimens included examples of butt welds, lap welds with two beads, and lap welds with one bead. Stressed specimens of Titanium $75 \mathrm{~A}$ material, welded and unwelded, were included in this series. The weldments ran transversely across the specimens, which were surface ground to give coupons of uniform thickness. The specimens were necked down slightly at and around the weld to concentrate the stresses at that point, then bent into U-shapes, and held in the stressed condition by keepers.

Figure 40 shows the apparatus used to conduct these experiments. Specimens were exposed to the liquid and vapor in the flask and to vapor and condensate in the side arm leading to the condenser. Figure 41 shows the relative positioning.

Operation of this flowing dissolver was terminated following $2000 \mathrm{hr}$ under dissolution conditions. A few specimens had been examined at $1061 \mathrm{hr}$. Approximately $40 \mathrm{lb}$ of Type 304 stainles steel rod was dissolved in about 80 gal of acid during the experiment.

All the specimens from the liquid phase were covered with a hard, green siliceous scale. Vigorous scrubbing did not remove the scale, but treatment with boiling $10 \mathrm{w} / 0 \mathrm{NaOH}$ was effective.

Table 20 shows the locations of the specimens and the weight changes noted. Because the specimens were irregularly shaped (welded), no corrosion rates are given. However, the rates were undoubtedly low, as evidenced by weight losses no greater than $7 \mathrm{mg}$.

All pieces were studied by low-power microscope and no evidence of attack at welds, crevices, or stressed areas was noted. Representative pieces were sectioned for metallographic examination. No adverse effects from this environment were found on butt welds, lap welds, or stressed areas. No evidence of hydride formation was observed in metallographic sections for any specimens. Figure 42 shows microsections of pieces of titanium lap welded with one bead after exposure for $2000 \mathrm{hr}$ at three places in the dissolver. The pictures show the welded areas and the crevices between the pieces of metal.

The titanium disk which supported the dissolving stainless steel rod was sectioned and bent after an exposure of $4483 \mathrm{hr}$. No embrittlement was noted. 


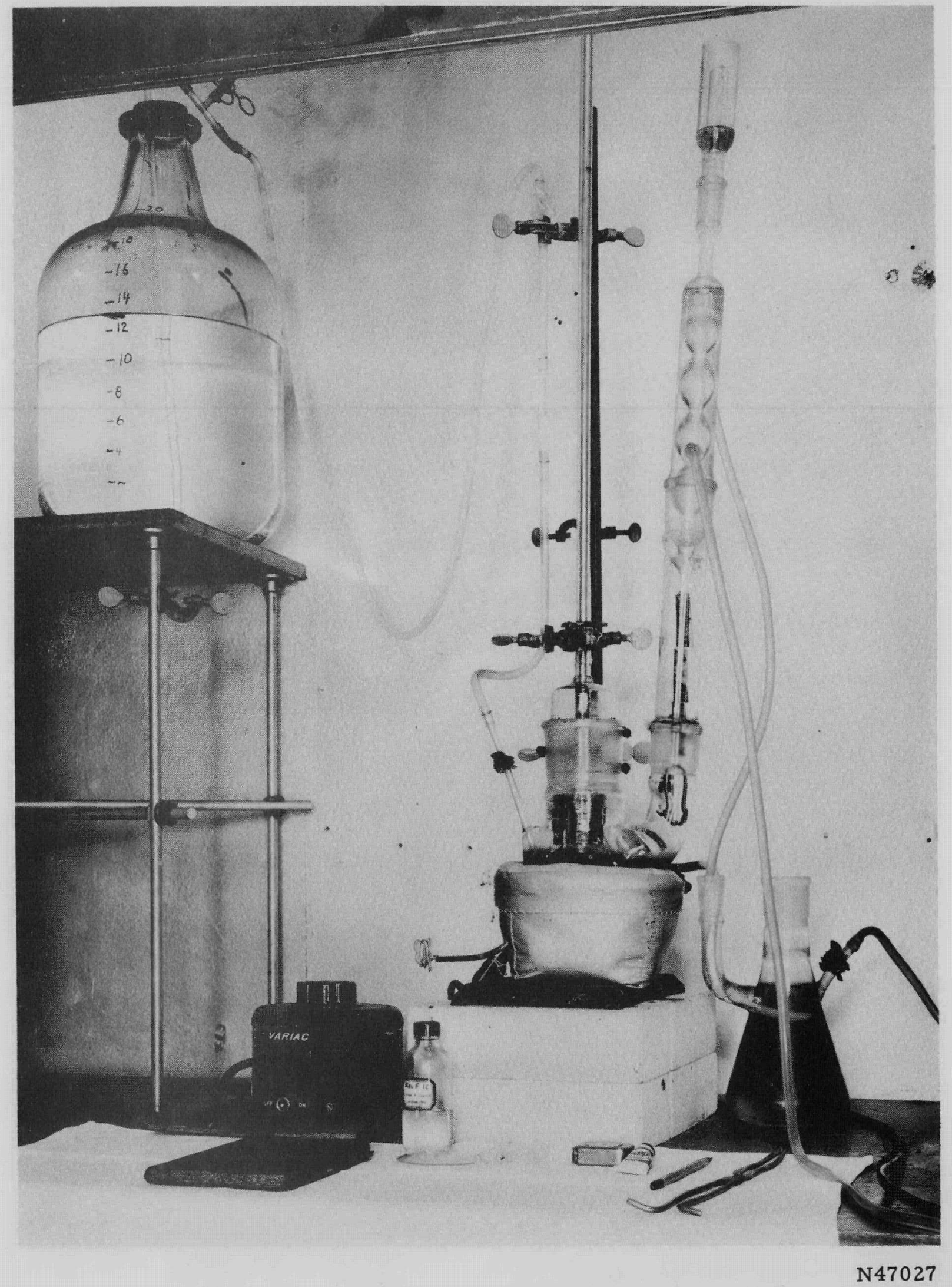

FIGURE 40. EQUIPMENT FOR CONDUCTING DAREX FLOWING-DISSOLVER STUDIES 


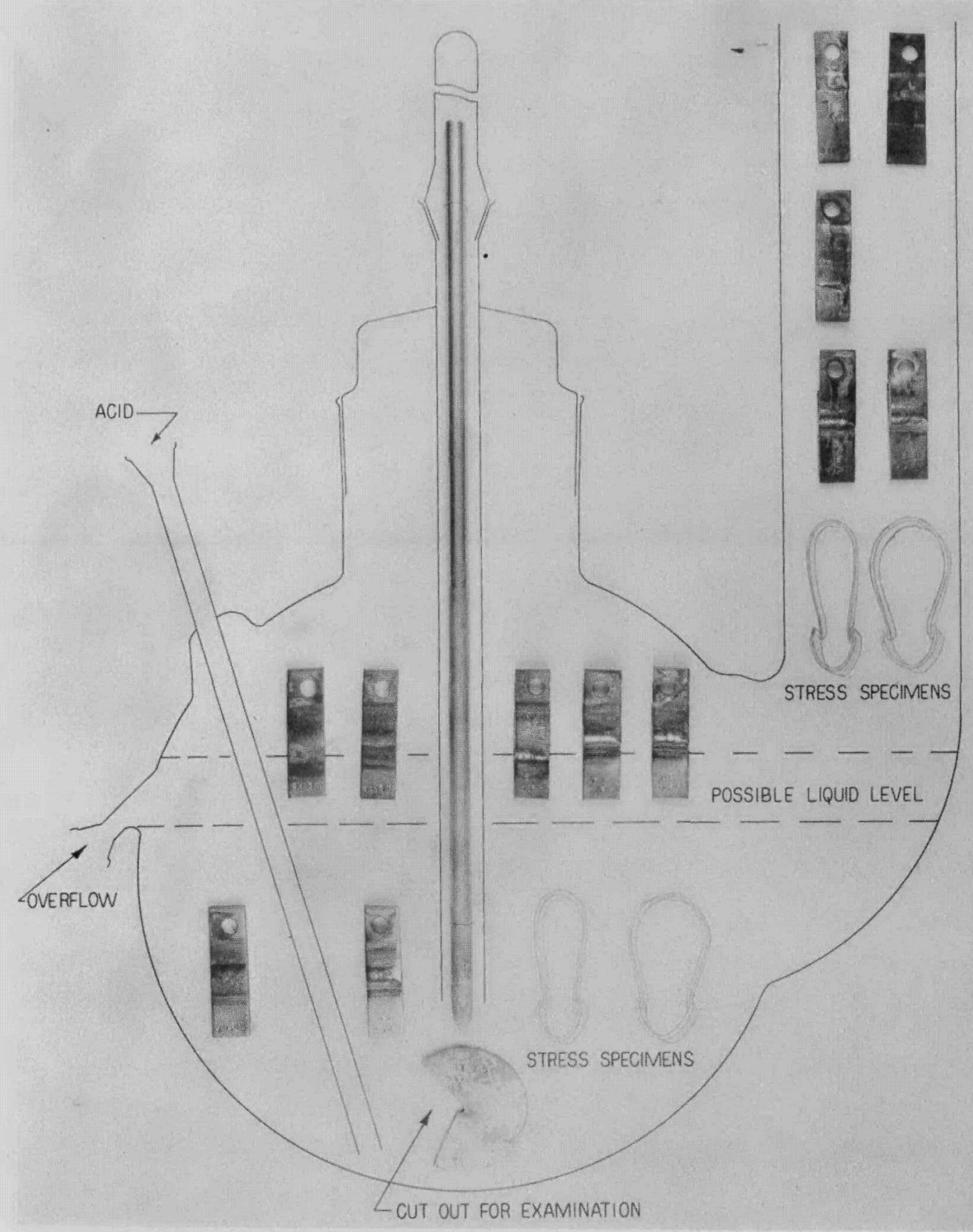

N50877

FIGURE 41. SCHEMATIC DIAGRAM OF DAREX FLOWING DISSOLVER INDICATING SPECIMEN POSITIONING 
TABLE 20. RESULTS WITH DAREX FLOWING-DISSOLVER SPECIMENS

\begin{tabular}{|c|c|c|c|c|}
\hline Specimen Type & Specimen & $\begin{array}{c}\text { Total Time, } \\
\mathrm{hr}\end{array}$ & $\begin{array}{c}\text { Weight Loss(a), } \\
\text { mg }\end{array}$ & Position(b) \\
\hline \multirow[t]{6}{*}{ Butt-welded Titanium 55} & $2 I-5$ & 2000 & I. 1 & Flask-L \\
\hline & $21-6$ & 2000 & 1.2 & Flask-V \\
\hline & $21-7$ & 2000 & 1.9 & Flask-L \\
\hline & $21-8$ & 2000 & 1.1 & Flask-V \\
\hline & $21-9$ & 2000 & 2.6 & Side arm-1 \\
\hline & $21-10$ & 2000 & 6.3 & Side arm-1 \\
\hline \multirow{6}{*}{$\begin{array}{l}\text { Lap-welded (two beads) } \\
\text { Titanium } 55\end{array}$} & $21-11$ & 2000 & 1.5 & Flask-L \\
\hline & $21-12$ & 1061 & 0.2 & Flask-L \\
\hline & $21-13$ & 2000 & 1. 1 & Flask-V \\
\hline & $21-14$ & 1061 & g 1.1 & Flask-V \\
\hline & $21-15$ & 1061 & 0.3 & Side arm-2 \\
\hline & $21-16$ & 2000 & 4. 2 & Side arm-2 \\
\hline \multirow{6}{*}{$\begin{array}{l}\text { Lap-welded (one bead) } \\
\text { Titanium } 55\end{array}$} & $21-17$ & 2000 & 2. 9 & Flask-L \\
\hline & $21-18$ & 2000 & 1. 2 & Flask-L \\
\hline & $21-19$ & 2000 & 0.9 & Flask-V \\
\hline & $21-20$ & 2000 & g 2.6 & Flask-V \\
\hline & $21-21$ & 2000 & 2. 0 & Side arm-3 \\
\hline & $21-22$ & 2000 & 2. 2 & Side arm-3 \\
\hline \multirow[t]{4}{*}{ Stressed Titanium $75 \mathrm{~A}$} & $21-23$ & 2000 & 1.0 & Flask-L \\
\hline & $21-24$ & 1061 & 0.4 & Flask-L \\
\hline & $21-25$ & 1061 & 0.7 & Side arm-4 \\
\hline & $21-26$ & 2000 & g 8.9 & Side arm-4 \\
\hline Disk of Titanium $75 \mathrm{~A}$ & $34-28$ & 4483 & -- & Flask-L \\
\hline Welded stressed & WT-3 & 276 & 0.6 & Side arm-4 \\
\hline Titanium $75 \mathrm{~A}$ & WT-4 & 276 & 0.5 & Flask-L \\
\hline
\end{tabular}

(a) Approximate area, 2 to 3 in. ${ }^{2}, \mathrm{~g}=$ weight gain.

(b) $\mathrm{L}=$ liquid and $\mathrm{V}=$ vapor. In side-arm positions, 1 is at top. 


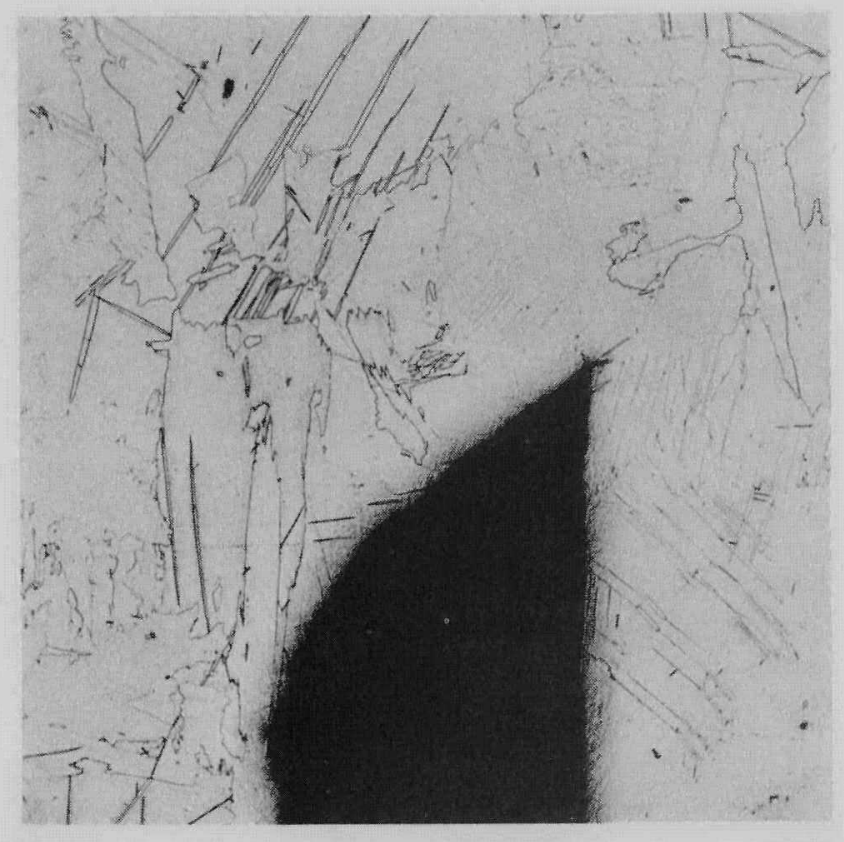

$100 \mathrm{x}$
C550

a. Specimen $21-18$, Exposed in Liquid

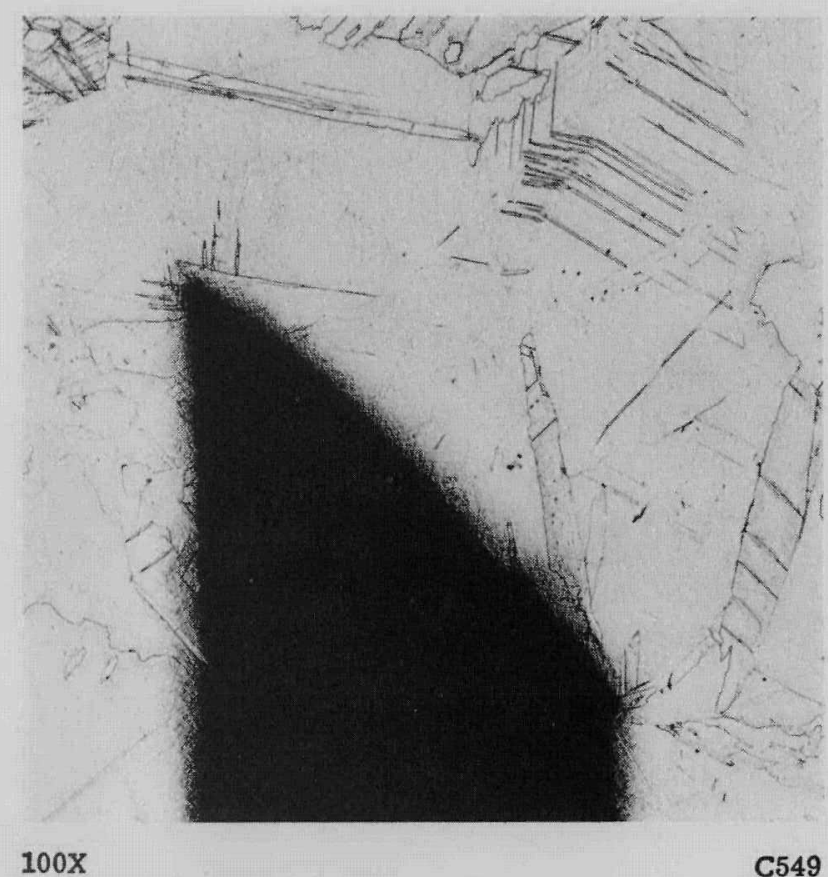

b. Specimen 21-21, Exposed in Vapor in Side Arm

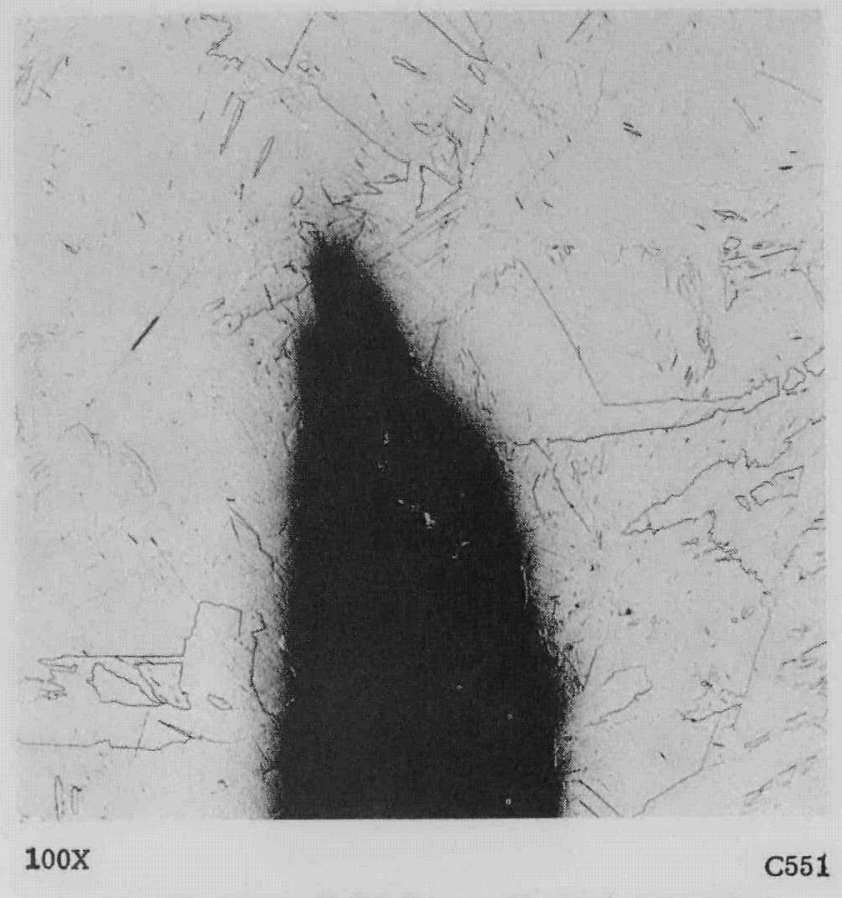

c. Specimen 21-19, Exposed in Vapor in Flask

FIGURE 42. CROSS SECTIONS OF LAP-WELDED TITANIUM SHOWING ABSENCE OF ATTACK AFTER 2000 HR IN THE FLOWING DAREX DISSOLVER 
It could be anticipated that the hard scale formed on all immersed surfaces under dissolution conditions could be detrimental to plant operation of a Darex dis solver. Since boiling $10 \mathrm{w} / \mathrm{o} \mathrm{NaOH}$ removes the scale, a study was made to determine if the titanium might be harmed in any way by such cleaning treatments. A flowing dissolver similar to that described in the above sections was run on a schedule wherein the scale was removed once a week, over a period of 13 weeks $(2008 \mathrm{hr})$, by a $3-\mathrm{hr}$ treatment with boiling caustic solution. Various plain, welded, and stressed titanium specimens were exposed as is indicated in Table 21. It should be noted that Specimens 21-5, $21-11,21-17,21-23$, and 21-26, along with WT-3 and WT-4, had been exposed previously in the experiment summarized in Table 20. The new specimens included stressed pieces of a different type, in which the weldment ran longitudinally down the center of the specimen. These are illustrated in Figure 43, which also shows the titanium stress jig which was used for holding the specimens.

Table 21 shows that two specimens which were exposed in the vapor were scratched daily. This was done to ascertain if injuries to the protective film could lead to increased corrosion rates. No increase was found.

The dissolving and cleaning regimen was continued for a total of $2008 \mathrm{hr}$ after which the specimens were weighed and examined. Table 21 shows that relatively small weight changes were observed. Representative specimens were sectioned and examined. No apparent attack was observed at crevices or welds or as a result of stress.

It was concluded that caustic cleaning should be a safe operating procedure and that mechanical action probably would not cause accelerated local corrosion.

Titanium Steam Tubes

It is anticipated that steam may be passed through titanium tubes to heat the Darex solutions. Three experiments were conducted in Darex dissolver solutions in order to ascertain whether titanium is more severely corroded when heat transfer takes place across the surface of the metal. The tubes were about $3 / 8 \mathrm{in}$. in diameter and were bent to a U-shape. A weld bead was placed at the bottom of the bend to simulate fabrication of joints. The tubes were mounted in wide-mouthed Pyrex flasks which contained the Darex solutions. Figure 44 shows two setups in different stages of assembly.

Steam at about $135 \mathrm{C}$ was passed through the tubes to maintain the solutions at boiling. The solution compositions in moles per liter were:

\begin{tabular}{|c|c|c|c|c|c|c|c|}
\hline & $\underline{\mathrm{H}^{+}}$ & $\mathrm{Cl}^{-}$ & $\mathrm{NO}_{3}^{-}$ & $\mathrm{Fe}^{+3}$ & $\mathrm{Cr}+3$ & $\mathrm{Ni}^{++}$ & $\mathrm{U}^{+6}$ \\
\hline Initial & 7.0 & 2.0 & 5.0 & -- & -- & -- & -- \\
\hline Beginning & 7.0 & 2.0 & 5.05 & 0.01 & 0.003 & 0.0012 & 0.004 \\
\hline & 4.0 & 1.89 & 4.73 & 0.55 & 0.15 & 0.06 & 0.2 \\
\hline
\end{tabular}


TABLE 21. RESULTS WITH DAREX DISSOLVER SPECIMENS GIVEN A CLEANING REGIMEN OVER A 13-WEEK PERIOD

\begin{tabular}{|c|c|c|c|}
\hline Specimen Type & Specimen & $\begin{array}{l}\text { Weight Loss } \\
\mathrm{mg}\end{array}$ & $\begin{array}{l}\text { Exposure } \\
\text { Position (b) }\end{array}$ \\
\hline Coupon of Titanium 75A (scratched daily) & $M-1$ & 0.9 & Side arm-1 \\
\hline Coupon of Titanium 55 (scratched daily) & $O R-50$ & 1.0 & Side arm-1 \\
\hline Coupon of Titanium $75 \mathrm{~A}$ & M-3 & 6.0 & Side arm-2 \\
\hline Coupon of Titanium 55 & OR -52 & 0.7 & Side arm-2 \\
\hline Coupon of Titanium $75 \mathrm{~A}$ & $\mathrm{M}-2$ & 5.2 & Flask-L \\
\hline Coupon of Titanium $75 \mathrm{~A}$ & $M-4$ & 8.3 & Flask-L \\
\hline Coupon of Titanium 55 & $\mathrm{OR}-51$ & 4.7 & Flask-L \\
\hline Coupon of Titanium 55 & OR -53 & 4.2 & Flask-L \\
\hline Butt-welded Titanium 55 & $21-5$ & 32.2 & Flask-L \\
\hline Lap-welded (two beads) Titanium 55 & $21-11$ & 3.0 & Flask-L \\
\hline Lap-welded (one bead) Titanium 55 & $21-17$ & g 5.5 & Flask-L \\
\hline Plain horseshoe stressed Titanium $75 \mathrm{~A}$ & $\begin{array}{l}21-26 \\
21-23\end{array}$ & $\begin{array}{r}7.8 \\
2.8\end{array}$ & $\begin{array}{l}\text { Side arm-3 } \\
\text { Flask }-\mathrm{L}\end{array}$ \\
\hline $\begin{array}{l}\text { Cross-weld horseshoe stressed } \\
\text { Titanium } 75 \mathrm{~A}\end{array}$ & $\begin{array}{l}\mathrm{WT}-3 \\
\mathrm{WT}-4\end{array}$ & $\begin{array}{l}2.8 \\
2.6\end{array}$ & $\begin{array}{l}\text { Side arm-3 } \\
\text { Flask-L }\end{array}$ \\
\hline Length-weld stressed Titanium $75 \mathrm{~A}$ & $\begin{array}{l}\text { WL-1 } \\
\text { WL-3 } \\
\text { WL-2 } \\
\text { WL-4 }\end{array}$ & $\begin{array}{l}4.4 \\
9.0 \\
9.2 \\
9.4\end{array}$ & $\begin{array}{l}\text { Side arm-4 } \\
\text { Side arm-4 } \\
\text { Flask-L } \\
\text { Flask-L }\end{array}$ \\
\hline Disk of Titanium $75 \mathrm{~A}$ & $\mathrm{D}-2$ & 7.9 & Flask-L \\
\hline
\end{tabular}

${ }^{2} . \mathrm{g}=$ weight gain.

(b) $\mathrm{L}=$ liquid. In side-arm positions, 1 is at top. 


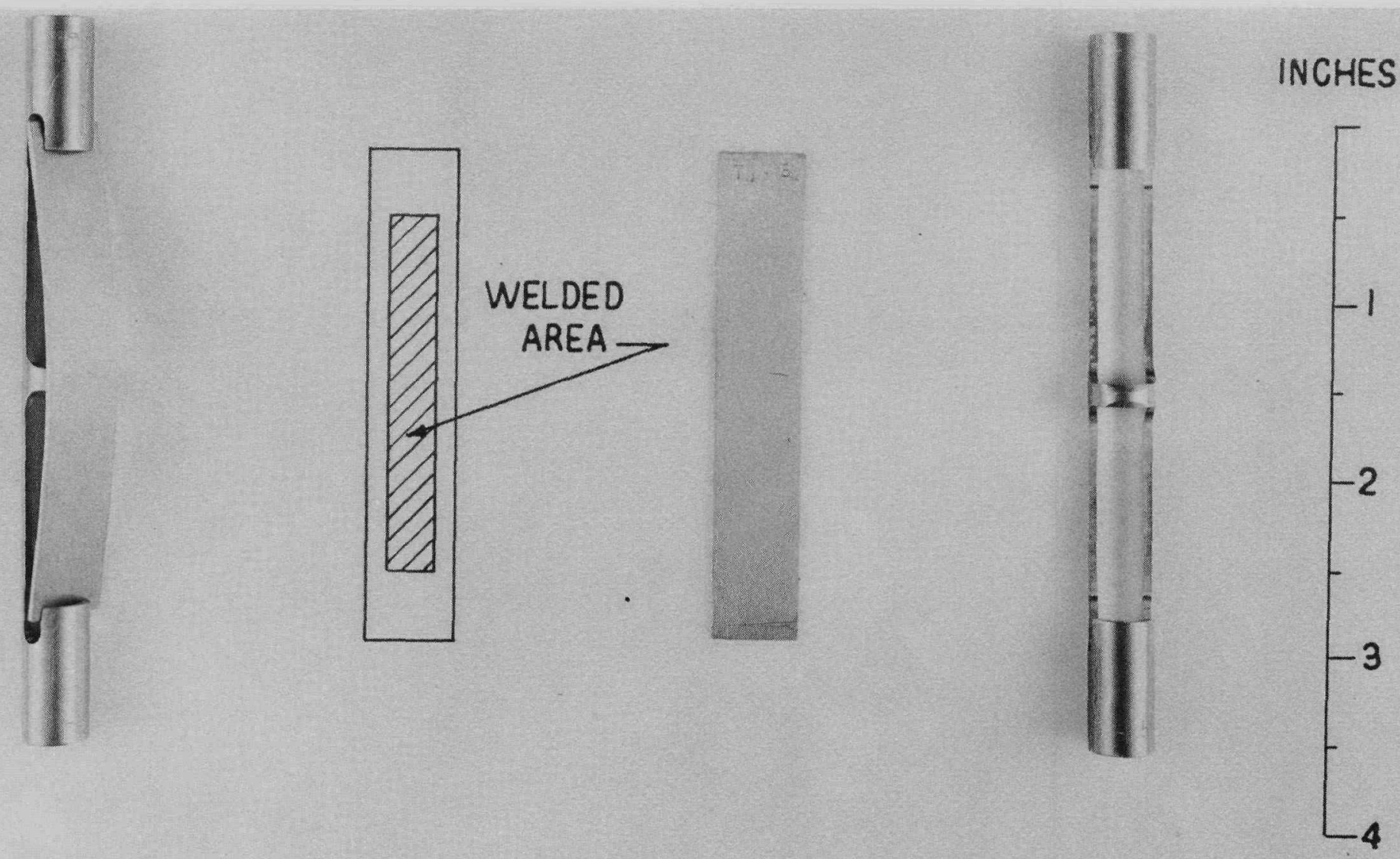

STRESSED TO APPROXIMATELY 90 PER CENT OF YIELD STRENGTH

N5 1083

FIGURE 43. TITANIUM STRESS SPECIMENS AND HOLDERS AS USED IN DAREX FLOWING-DISSOLVER STUDY 


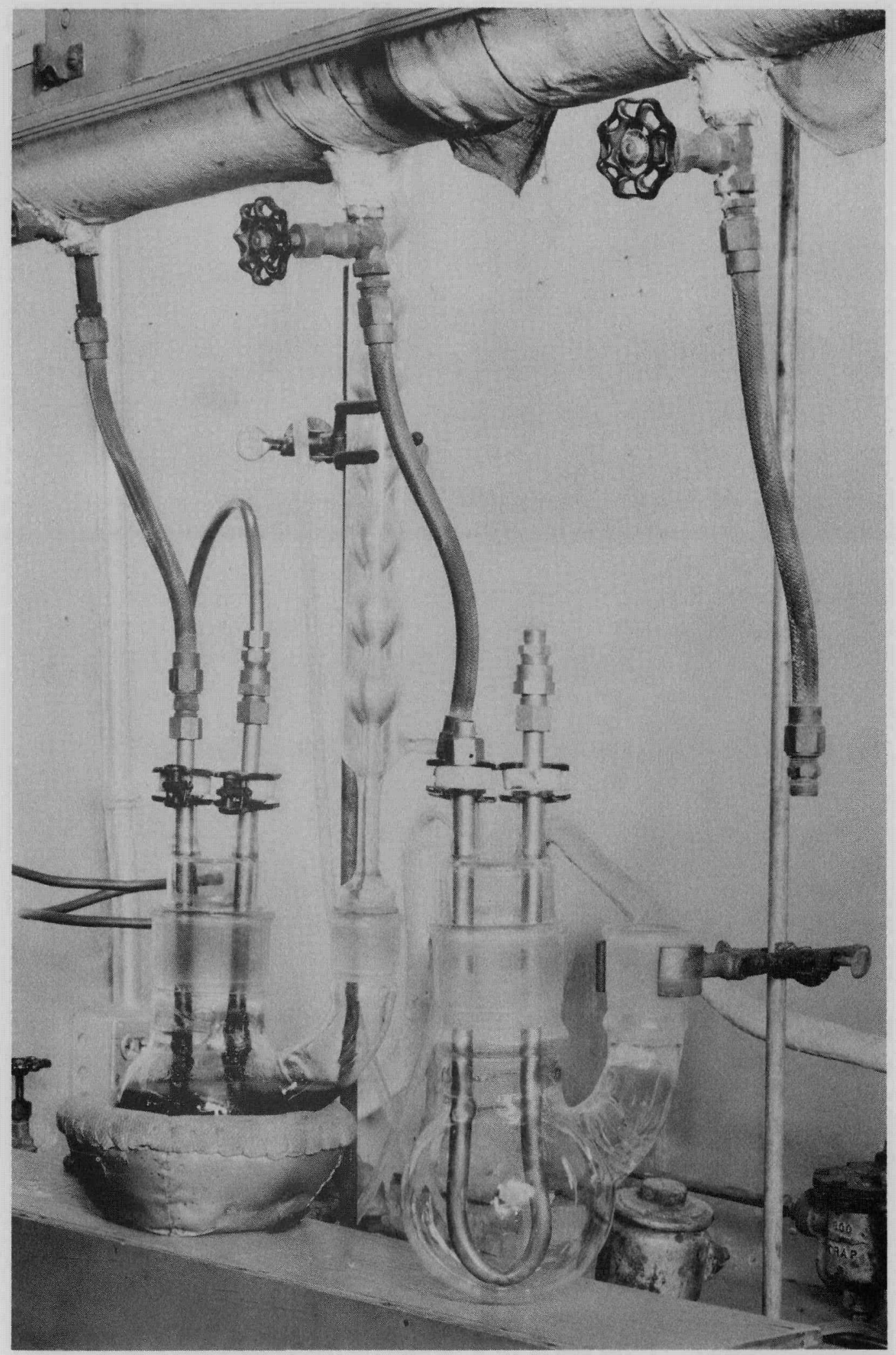

N47028

FIGURE 44. TITANIUM STEAM-TUBE APPARATUS FOR CORROSION STUDIES IN THE PRESENCE OF HEAT TRANSFER 
The tube exposed to the Initial solution was covered with a thin white crust at and above the interface when examined after about 1000 and $2000 \mathrm{hr}$. No serious corrosion was evident in microsections taken at the interface and weld areas.

The precision in the determination of the corrosion rates by measuring the decrease in wall thickness of the tubes, as shown by metallographic sections, was hampered by the lack of uniformity in the original wall thickness. Estimates are that, after $2010 \mathrm{hr}$ in the Initial Darex dissolver solution, the average corrosion rate was in the range of 1.5 to 2 mils per month. Hairline cracks observed near the interface on this tube at the $1000-\mathrm{hr}$ inspection did not reappear during the second $1000-\mathrm{hr}$ exposure on new sections of the tube inserted at the interface zone. It is thought that imperfections were present but unnoticed in the tubing as received and were made apparent by corrosion during the first 1000 -hr period.

A thin white coating covered the immersed section of the tube from the Beginning solution. This coating was easily removed by water.

A very hard adherent scale remained at the interface, resisting hot uncontaminated Initial solution, but softening slightly in hot $10 \mathrm{w} / \mathrm{o} \mathrm{NaOH}$. This tube showed some general surface roughening.

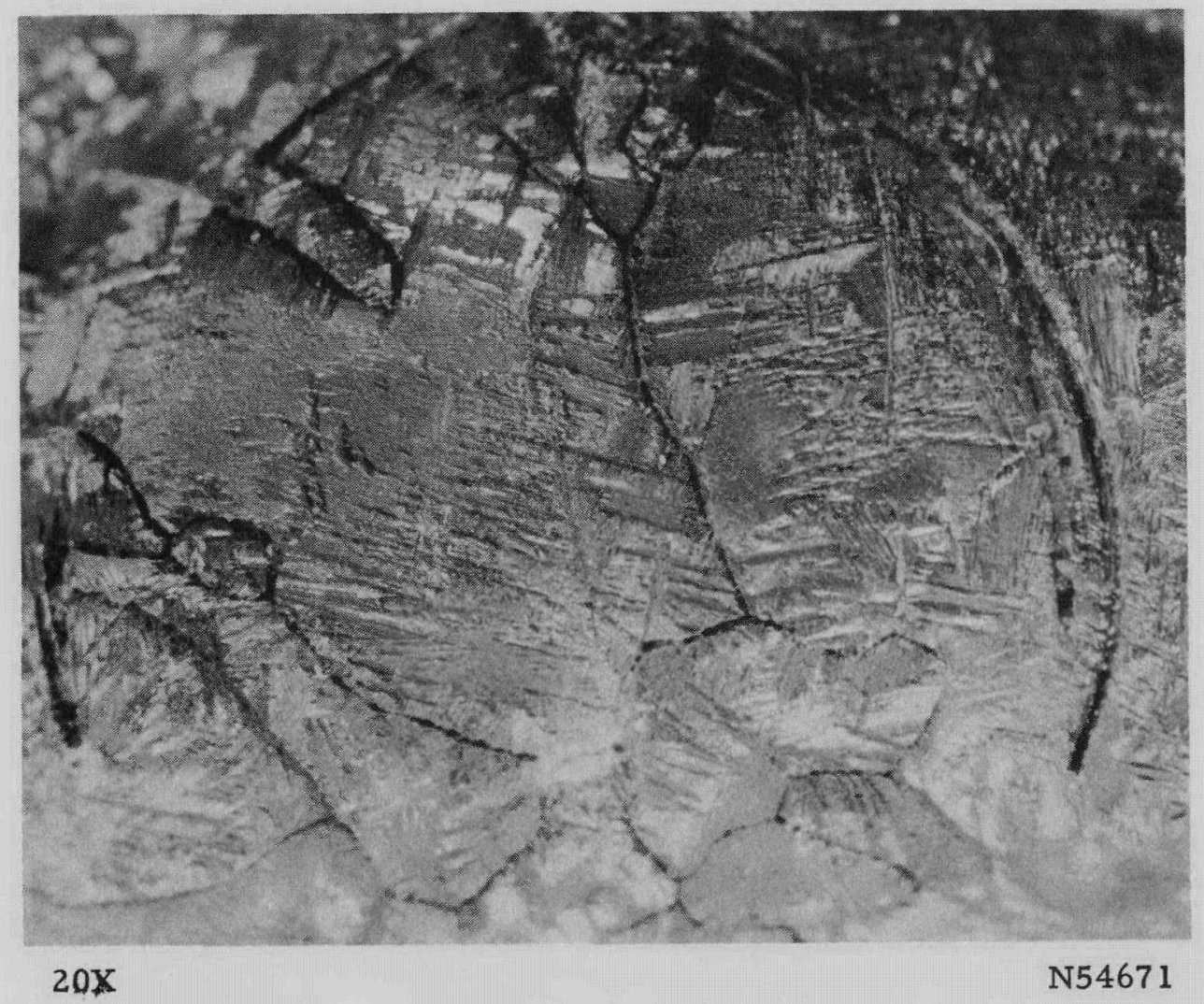

FIGURE 45. WELDMENT IN TIT ANIUM STEAM TUBE AFTER 1040-HR EXPOSURE TO BEGINNING DAREX SOLUTIONS AT $135 \mathrm{C}$

The crevices visible in the weldment are relatively shallow. 
A corrosion rate from 0.5 to $1 \mathrm{mil}$ per month was observed after $2049 \mathrm{hr}$. There were crevices in the weldment of this tube after $2049 \mathrm{hr}$ similar to those observed on the same tube after $1040 \mathrm{hr}$, but sectioning showed these to be reasonably shallow and apparently no cause for concern. Figure 45 shows the appearance of one of these areas at low magnification.

No attack could be detected visually or metallographically on the tube exposed to Middle Darex solution for $2000 \mathrm{hr}$. A hard scale was formed near the interface and was removed with some difficulty in Darex and caustic solutions.

Thus, it is concluded that titanium can be expected to withstand all the normal operating conditions of the Darex dissolver without undergoing excessive attack. If these tubes are inserted below the liquid level, the interface conditions and the attendant scale-formation problems will never exist. It must be emphasized, however, that hydrochloric acid in the absence of nitric acid attacks titanium rapidly and the presence of such conditions must be scrupulously avoided.

Darex Transfer Lines

A study was conducted to determine if an existing Type 304 ELC stainless stee1 pipeline at ORNL could be used to transfer solution from the Darex dissolver. Welded and machined Type 304 ELC stainless steel specimens were stirred at 3 and 6 linear ft per sec in a synthetic solution at $125 \mathrm{~F}$. The solution in question was $1.75 \mathrm{M} \mathrm{HC1}$, 1. $2 \mathrm{M} \mathrm{HNO}_{3}, 0.68 \mathrm{M} \mathrm{Fe}^{+3}, 0.21 \mathrm{M} \mathrm{Cr}^{+3}, 0.09 \mathrm{M} \mathrm{Ni}^{++}$, and $100 \mathrm{~g}$ per liter $\mathrm{U}^{+6}$ (all salts added as nitrates).

An active-passive condition was found to exist with Type 304 ELC stainless in this solution. Catastrophic attack occurred on several specimens, while little or no attack occurred on others. This attack occurred at a velocity of 6 linear $\mathrm{ft}$ per sec and at as low a temperature as $105 \mathrm{~F}$. It appears that the parameters of temperature, velocity, and chloride concentration are important to this active-passive state. Use of this pipeline for handling the solution under consideration is not recommended. Further investigation of the parameters listed may lead to an operating technique by which the pipe could be used safely.

\section{$\underline{\text { FAT Studies }}$}

The uranium-bearing liquid from the Darex dissolver must be treated by proper methods to reduce the chloride concentration to a safe level for the stainless steel equipment in which solvent extraction is carried out. In addition, the nitric acid concentration must be adjusted to a value consistent with good extraction. Several operations, such as refluxing, boildown, and dilution, may be performed to accomplish these ends. Plans call for all steps to be carried out in a titanium vessel termed a feed-adjustment tank (FAT).

Titanium, as a material of construction for the FAT, was evaluated by exposing specimens to two solutions which represented possible extremes from processing 
TABLE 22. CORROSION OF TITANIUM SPECIMENS IN BOILING

\begin{tabular}{|c|c|c|c|c|c|c|c|c|c|}
\hline \multirow[b]{3}{*}{ Specimen Type } & \multirow{3}{*}{$\begin{array}{l}\text { Specimen } \\
\text { Position }\end{array}$} & & \multicolumn{4}{|c|}{ Corrosion } \\
\hline & & \multicolumn{2}{|c|}{$154 \mathrm{Hr}$} & \multicolumn{2}{|c|}{$164 \mathrm{Hr}$} & \multicolumn{2}{|c|}{$666 \mathrm{Hr}$} & \multicolumn{2}{|c|}{$1170 \mathrm{Hr}$} \\
\hline & & $\mathrm{A}$ & B & $\mathrm{A}$ & B & $\mathrm{A}$ & $\bar{B}$ & A & B \\
\hline \multirow[t]{3}{*}{ Plain Titanium $75 \mathrm{~A}$} & Vapor & -- & -- & .037 & .040 & .027 & .045 & .032 & .042 \\
\hline & Interface & -- & -- & .006 & .004 & .004 & .003 & .001 & .002 \\
\hline & Liquid & -- & -- & .012 & .014 & .005 & .005 & .003 & .003 \\
\hline \multirow[t]{3}{*}{ Butt-welded Titanium $55 \mathrm{~A}$} & Vapor & -- & -- & .028 & -- & .034 & -- & .043 & -- \\
\hline & Interface & -- & -- & .014 & -- & .006 & -- & .003 & -- \\
\hline & Liquid & - & - & .018 & -- & .006 & -- & .005 & -- \\
\hline \multirow[t]{2}{*}{ Stressed Titanium $75 \mathrm{~A}^{(\mathrm{f})}$} & Vapor & .063 & .046 & -- & -- & -- & -- & -- & -- \\
\hline & Liquid & .029 & .040 & -- & - & -- & -- & -- & -- \\
\hline \multirow[t]{3}{*}{ Lap-welded (two beads) Titanium 55A } & Vapor & -- & -- & -- & -- & -- & -- & -- & -- \\
\hline & Interface & - & -- & -- & -- & -- & - & - & -- \\
\hline & Liquid & -- & -- & -- & -- & -- & -- & -- & -- \\
\hline
\end{tabular}

(a) The composition of this solution is:

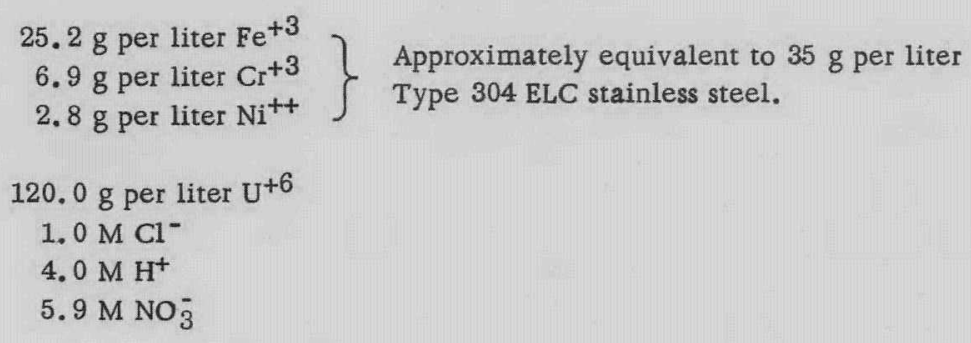

The boiling point is $109 \mathrm{C}$. 
INITIAL FEED-ADJUSTMENT -TANK (FAT) SOLUTIONS ${ }^{\text {(a) }}$

\begin{tabular}{|c|c|c|c|c|c|c|c|c|c|c|c|}
\hline \multicolumn{12}{|c|}{ Rate for Duplicate(b) Specimens at Time Shown, mil per month } \\
\hline \multicolumn{2}{|c|}{$1993 \mathrm{Hr}$} & \multicolumn{2}{|c|}{$2003 \mathrm{Hr}$} & \multicolumn{2}{|c|}{$2619 \mathrm{Hr}$} & \multicolumn{2}{|c|}{$3500 \mathrm{Hr}$} & \multicolumn{2}{|c|}{$4500 \mathrm{Hr}(\mathrm{c})$} & \multicolumn{2}{|c|}{$4500 \mathrm{Hr}(\mathrm{d})$} \\
\hline A & B & A & B & A & B & A & B & A & B & A & B \\
\hline-- & - & .057 & .074 & .049 & .069 & .053 & .077 & .067 & .089 & .067 & .089 \\
\hline -. & -- & .002 & $.002^{(\mathrm{e})}$ & .001 & .. & .001 & -. & .001 & -. & .001 & -. \\
\hline- & -- & .002 & .002 & $.002^{(e)}$ & .002 & -- & .002 & -- & .000 & -- & .001 \\
\hline- & -- & .040 & - & .044 & - & .046 & -. & .050 & -- & .050 & -- \\
\hline-- & -- & .002 & - & .001 & -- & .000 & -. & .000 & -- & .003 & -- \\
\hline- & -- & .004 & - & .003 & -- & .002 & -- & .001 & -- & .003 & -- \\
\hline .140 & $.101^{(\mathrm{e})}$ & -- & -- & -- & -- & .131 & -. & .154 & -- & .154 & -- \\
\hline $\mathrm{g}(0.6 \mathrm{mg})$ & $\mathrm{g}(0.1 \mathrm{mg})$ & -- & -. & -- & -- & $\mathrm{g}(1.6 \mathrm{mg})$ & $\mathrm{g}(0.8 \mathrm{mg})$ & $\mathrm{g}(9.1 \mathrm{mg})$ & $\mathrm{g}(7.8 \mathrm{mg})$ & .002 & .002 \\
\hline .023 & - & -. & -. & .037 & -. & .035 & -- & .037 & -- & .038 & -- \\
\hline $\mathrm{g}(2.4 \mathrm{mg})$ & -- & -- & -- & $\mathrm{g}(4.9 \mathrm{mg})$ & -- & $\mathrm{g}(6.6 \mathrm{mg})$ & -. & $\mathrm{g}(2.8 \mathrm{mg})$ & -- & $\mathrm{g}(0.6 \mathrm{mg})$ & -- \\
\hline .006 & -- & -- & -- & .004 & -- & .003 & -- & .003 & -- & .004 & -- \\
\hline
\end{tabular}

(b) A and B columns represent duplicate tests.

(c) Corrosion rate before $\mathrm{NaOH}$ cleaning.

(d) Corrosion rate after boiling three hours in $10 \mathrm{w} / \mathrm{o} \mathrm{NaOH}$.

(e) Specimens selected for metallographic examination.

(f) Based on combined weight of stressed specimen and its keeper.

Note: $g$ indicates a small gain in weight as shown. 
Yankee Atomic fuel elements. One of the solutions is the entering stream, i.e., the dissolver effluent, and the other is the final adjusted solution ready for solvent extraction. The compositions of these solutions are:

\begin{tabular}{|c|c|c|c|c|c|c|c|c|}
\hline & \multicolumn{7}{|c|}{ Composition, moles per liter } & \multirow{2}{*}{$\begin{array}{l}\text { Boiling } \\
\text { Point, } \\
\end{array}$} \\
\hline & $\mathrm{H}^{+}$ & $\mathrm{Cl}^{-}$ & $\mathrm{NO}_{3}-$ & $\mathrm{Fe}^{+3}$ & $\mathrm{Cr}^{+3}$ & $\mathrm{Ni}^{++}$ & $\mathrm{U}^{+6}$ & \\
\hline itial & 4.0 & 1.0 & 5.9 & 0.45 & 0.13 & 0.048 & 0.51 & 109 \\
\hline Final & 3.4 & Trace & 12.7 & 1.62 & 0.48 & 0.17 & 1.35 & 124 \\
\hline
\end{tabular}

Three boiling reflux units were used to evaluate titanium as a container material. Butt-welded and lap-welded specimens of Titanium 55A were in one flask, stressed specimens (horseshoe type) of Titanium 75A were in a second, and flat coupons of Titanium $75 \mathrm{~A}$ were in the third. The Initial solution composition is tabulated above.

The specimens were examined periodically and returned to the solution which was renewed after 1 week and then at 3 - to 5-week intervals thereafter. The specimens were washed and brushed in water, rinsed in acetone, and dried. The corrosion rates, which are quite low, are given in Table 22. To determine if any corrosion products or scale remained in crevices or on the surface, these specimens were exposed in boiling $10 \mathrm{w} / 0 \mathrm{NaOH}$ for $3 \mathrm{hr}$. Little weight change was noted, as shown by the corrosion rates after cleaning also given in Table 22. Several of these specimens were sectioned for metallographic examination. No adverse corrosion was found and no hydride formation was noted.

Since boildown operations are an eventuality, in which case steam coils of titanium would be used, titanium was evaluated by experiments in which heat transfer across the surfaces of the titanium specimens occurred.

Four assemblies similar to those shown in Figure 44 were used to evaluate $\mathrm{U}$-shaped titanium steam tubes.

One titanium tube was exposed to the Initial solution. Two tubes were exposed to the Final solution. A fourth tube was exposed to the Final solution in apparatus containing a Soxhlet extractor in between the condenser and the arm of the flask. Thus, this solution periodically increased in concentration above the Final solution shown above. A greater density of brown fumes of oxides of nitrogen was noted in this unit at the low-boildown stage. The tubes and their compositions are listed in Table 23.

TABLE 23. TITANIUM STEAM TUBES EXPOSED TO BOILING FAT SOLUTIONS

\begin{tabular}{cclc}
\hline \hline Tube & $\begin{array}{c}\text { Titanium } \\
\text { Designation }\end{array}$ & \multicolumn{1}{c}{$\begin{array}{c}\text { FAT } \\
\text { Solution }\end{array}$} & $\begin{array}{c}\text { Exposure, } \\
\text { hr }\end{array}$ \\
\hline & & & 3893 \\
2 & A-40 & Initial & 3647 \\
3 & A-40 & Final & 3511 \\
4 & A-55 & Final & 3826 \\
\hline \hline
\end{tabular}


Tube 1 was removed after 5 weeks of exposure to the Initial FAT solution. A thin, easily removable crystalline coating had formed beneath the liquid line. At and above the liquid line an appreciable buildup of very adherent dried salts had occurred. No apparent attack was noted upon removal of most of this deposit. The tube was replaced in fresh solution and the exposure was continued.

Titanium steam-tube specimens were also inspected after 5 and 8 weeks of exposure to solutions representing final conditions in the feed-adjustment tank. A much greater buildup occurs at and above the meniscus in the more concentrated Final solution. The deposit was much more difficult to remove than the crystalline coating which forms on the portion submerged in the liquid phase. These tubes were given a crude cleaning and again no attack was apparent. The tubes were returned to fresh solutions and continued exposure.

Tube 3 was removed following slightly over 10 weeks of exposure to the Final FAT solution. A portion of the tube surrounding the meniscus and under the large deposit that accumulates at the interface was removed and sectioned. Metallographic examination revealed no necking down of the thickness of the specimen tube nor any changes in its microstructure that might indicate any serious attack occurring beneath this deposit. The tube was welded together and replaced on test.

The tubes were exposed for a total of more than $3500 \mathrm{hr}$ before the study was terminated. Table 23 gives the exact times.

Identification of the crystals deposited on the tubes was attempted by X-ray spectrography, but the results were inconclusive because of lack of a similar pattern in the reference standards. A semiquantitative spectrographic analysis showed that the scale was predominantly iron with 10 to $40 \mathrm{w} / 0$ chromium, 1 to $10 \mathrm{w} / 0$ uranium, and 0.05 to $0.5 \mathrm{w} / \mathrm{o}$ of both nickel and silicon.

The scale which forms on the submerged section of the steam tubes could be removed by Initial FAT solution at room temperature. This exposure required about $2 \mathrm{hr}$ to remove the scale formed in the Final FAT solution and $1 \mathrm{hr}$ for the scale formed in the Initial FAT solution. Thus, it appears that no difficulty will be encountered in the heat-transfer characteristics of the steam tubes as a result of this scale.

Metallographic examinations were made of the steam-heated U-shaped titanium tubes exposed to various FAT solutions. Sections were made near the interface position and at the weld area at the bottom of the U-bend. No appreciable attack was noted. On the basis of these experiments, the use of titanium in feed-adjustment-tank solutions appears satisfactory.

\section{Chloride-Contaminated Purex Extraction Systems}

Specimens of Type 347 stainless steel were exposed to Purex extraction solutions containing chloride contaminations such as might occur during extraction of uranium from Darex solutions. Two types of aqueous solutions were used; both were $2 \mathrm{M} \mathrm{HNO}_{3}$ with one high in stainless steel ions, low in uranium, and the other high in uranium, low in stainless steel. The aqueous solution was mixed with an organic phase in the 
ratio of 2 to 3; the organic phase consisting of 1 part, by volume, of tributyl phosphate to 2 parts of Apco 125. Chloride contaminations from $2 \mathrm{ppm}$ to $1.00 \mathrm{w} / 0$ in the aqueous phase were studied in separate experiments.

Specimens in the form of disks, coupons stressed to 90 per cent of their yield strength, and coupons bent past their elastic limit into the shape of horseshoes were exposed. These were submerged in the aqueous phase of the system contained in long, stoppered tubes. The tubes were kept at room temperature and, during the first few weeks, the specimens were removed daily while the two-phased system was intimately mixed by vigorous shaking.

When no attack developed during the first few months, the specimens were inspected at 6-month intervals. After 2 years of exposure, the study was discontinued. No sign of attack was observed on any of the specimens except for a slight brightening of the surfaces. The weight changes were insignificant. No cracking or other localized attack could be found even upon a metallographic study of the specimens from the solutions containing the highest chloride contaminations.

Under the conditions of these experiments, there is no indication that even large chloride contaminations will cause corrosion of Type 347 stainless steel Purex extraction-system equipment.

\section{Fission-Product-Recovery Solutions}

Following solvent extraction for uranium removal from pregnant solutions produced by the Darex process, a further extraction procedure is contemplated for fissionproduct recovery. The approximate composition of the solution to be treated will be $3 \mathrm{MHNO}_{3}$ with $60 \mathrm{~g}$ per liter of dissolved Type 304 ELC stainless steel. It is expected that the temperature may reach boiling and chloride levels as high as $800 \mathrm{ppm}$ may occur. It was hoped that the fission-product-recovery solutions might be handled in Type 304 ELC or Type 347 stainless steel, since these materials are often employed for containing boiling nitric acid. Concern over the possibility of stress-corrosion cracking occurring from the chloride contamination led to a corrosion study of this system.

Specimens were cut from Type 304 ELC and Type 347 stainless steel. Half of these were coupons with a weldment running lengthwise through the specimen. The other specimens, also containing a longitudinal weldment, were bent into the shape of horseshoes and held in tension by keepers constructed from the same material. All of these specimens were surface ground so that no weld bead remained. The keepers, which were not ground, contained a transverse weld bead at their apex.

The first series of studies was conducted in the presence of $800 \mathrm{ppm} \mathrm{C1}^{-}$. Boiling solutions containing the equivalent of $60 \mathrm{~g}$ per liter dissolved Type 304 stainless steel, added as chromium, iron, and nickel salts, were used. No cracking developed, but intergranular attack and pitting soon became serious. Similarly constructed specimens of Type 347 stainless steel were exposed in chloride-free solutions and in solutions containing $400 \mathrm{ppm} \mathrm{C1}{ }^{-}$. The data for these studies are shown in Table 24. The corrosion rates for the liquid-phase Type 347 specimens exposed to the three $\mathrm{Cl}^{-}$ concentrations are shown in Figure 46. 
TABLE 24. CORROSION RATES FOR WELDED SPECIMENS OF TYPES 304 ELC AND 347 STAINLESS STEEL EXPOSED TO BOILING DAREX FISSION-PRODUCT-RECOVERY SOLUTION(a)

\begin{tabular}{|c|c|c|c|c|c|c|c|c|c|c|}
\hline \multirow{2}{*}{$\begin{array}{l}\text { Stainless } \\
\text { Specimen }\end{array}$} & \multirow[b]{2}{*}{ Specimen Type } & \multirow[b]{2}{*}{ Specimen Position } & \multirow{2}{*}{$\begin{array}{c}\text { Chloride } \\
\text { Addition, } \\
\text { ppm }\end{array}$} & \multicolumn{7}{|c|}{ Corrosion Rate at Time Shown, mils per month } \\
\hline & & & & $24 \mathrm{Hr}$ & $72 \mathrm{Hr}$ & $240 \mathrm{Hr}$ & $408 \mathrm{Hr}$ & $576 \mathrm{Hr}$ & $912 \mathrm{Hr}$ & $1250 \mathrm{Hr}$ \\
\hline \multirow[t]{3}{*}{ Type 304 ELC } & Coupon & Vapor & 800 & - & 0.10 & 0.07 & 0.07 & 0.08 & 0.07 & 0.07 \\
\hline & Coupon & Interface & 800 & - & 1.2 & 2.0 & 2.1 & 2.4 & 3.1 & 3.7 \\
\hline & Coupon & Liquid & 800 & - & 2.6 & 3.5 & 4.1 & 4.2 & 4.7 & 5.0 \\
\hline \multirow[t]{3}{*}{ Type 304 ELC } & Stressed & Vapor & 800 & -. & 0.15 & 1.9 & 1.2 & 0.90 & 0.61 & 0.52 \\
\hline & Stressed & Interface & 800 & - & 1.2 & 1.8 & 1.9 & 2.1 & 2.3 & 2.7 \\
\hline & Stressed & Liquid & 800 & -- & 1.5 & 2.5 & 3.0 & 3.1 & 3.6 & 3.9 \\
\hline \multirow[t]{3}{*}{ Type 347} & Coupon & Vapor & 800 & -. & 0.06 & 0.05 & 0.09 & 0.08 & 0.10 & 0.10 \\
\hline & Coupon & Interface & 800 & -- & 0.66 & 1.6 & 1.9 & 2.1 & 2.3 & 2.2 \\
\hline & Coupon & Liquid & 800 & -- & 1.4 & 2.6 & 2.6 & 3.4 & 3.7 & 3.7 \\
\hline \multirow[t]{3}{*}{ Type 347} & Stressed & Vapor & 800 & -- & 0.04 & 0.06 & 0.10 & 0.14 & 0.17 & 0.18 \\
\hline & Stressed & Interface & 800 & -- & 0.70 & 1.6 & 2.0 & 2.6 & 2.9 & 2.8 \\
\hline & Stressed & Liquid & 800 & - & 1.2 & 2.8 & 2.9 & 3.8 & 4.1 & 4.0 \\
\hline \multirow[t]{3}{*}{ Type 347} & Coupon & Vapor & 400 & 0.27 & 0.14 & 0.07 & -- & 0.11 & 0.12 & -. \\
\hline & Coupon & Interface & 400 & 1.3 & 1.2 & 1.3 & -. & 1.9 & 2.9 & -. \\
\hline & Coupon & Liquid & 400 & 1.8 & 1.9 & 2.3 & - & 3.5 & 4.4 & -- \\
\hline \multirow[t]{3}{*}{ Type 347} & Stressed & Vapor & 400 & 0.10 & 0.08 & 0.07 & -. & 0.06 & 0.08 & -- \\
\hline & Stressed & Interface & 400 & 1.2 & 1.2 & 1.6 & - & 2.5 & 3.3 & -- \\
\hline & Stressed & Liquid & 400 & 1.5 & 1.7 & 2.6 & -- & 4.0 & 4.4 & -- \\
\hline \multirow[t]{3}{*}{ Type 347} & Coupon & Vapor & -- & 0.30 & 0.11 & 0.08 & -- & 0.12 & 0.11 & -. \\
\hline & Coupon & Interface & -- & 0.53 & 0.94 & 1.3 & -- & 2.0 & 3.1 & - \\
\hline & Coupon & Liquid & -- & 1.1 & 1.4 & 2.6 & - & 4.3 & 5.2 & -- \\
\hline \multirow[t]{3}{*}{ Type 347} & Stressed & Vapor & -- & 0.08 & 0.05 & 0.09 & -. & 0.10 & 0.11 & -. \\
\hline & Stressed & Interface & -. & 0.72 & 0.90 & 1.6 & -- & 2.5 & 3.3 & - \\
\hline & Stressed & Liquid & -. & 0.97 & 1.2 & 3.1 & -- & 4.9 & 5.2 & -. \\
\hline
\end{tabular}

(a) Solution composition: $3 \mathrm{M} \mathrm{HNO}_{3}+60 \mathrm{~g}$ per liter dissolved stainless steel (Type 304). 


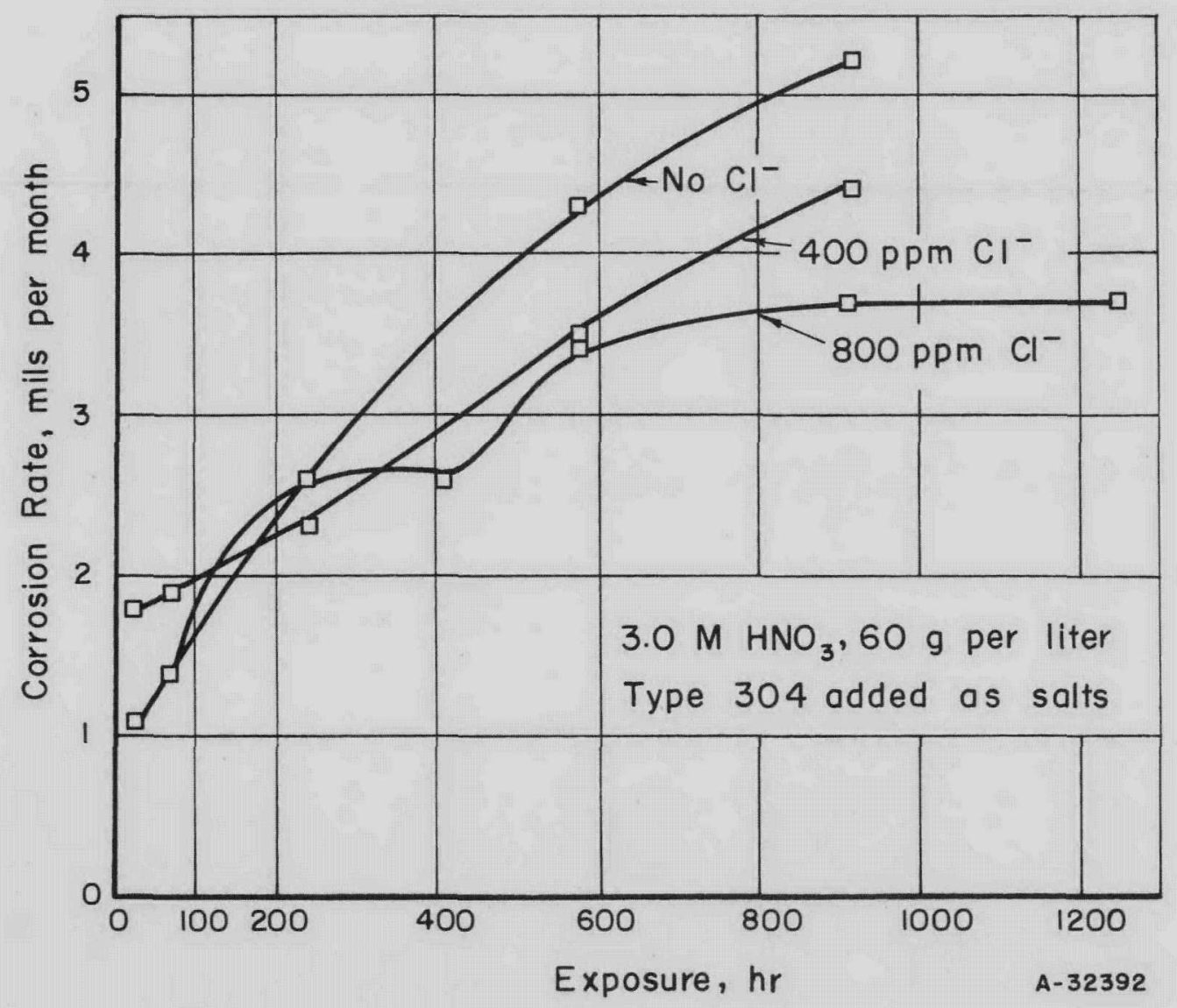

FIGURE 46. CORROSION OF SUBMERGED TYPE 347 STAINLESS STELL COUPONS IN BOILING DAREX FISSION-PRODUCT-RECOVERY SOLUTIONS 
No stress-corrosion cracking was observed. However, heavy attack occurred on the surfaces of all specimens independent of the chloride content of the solutions. A knife-line attack was so pronounced in one of the stressed Type 347 specimens after $1250 \mathrm{hr}$ that the longitudinal weldment was excised completely from the parent metal. Considerable intergranular attack was observed, being more localized in the heataffected areas of Type 347 specimens and uniformly distributed over the surface of Type 304 ELC specimens.

Since both these austenitic grades are reasonably resistant to localized attack by boiling nitric acid, there was some thought that the presence of hexavalent chromium in the solution might be responsible for the observed corrosion. Such effects have been established by investigators at ORNL. However, analyses showed that, following exposure, all of the solutions contained less than $5 \mathrm{mg}$ per liter of $\mathrm{Cr}^{+6}$. Apparently, this is not the causative factor.

Shirley and Truman(11) in 1952 indicated that ferric nitrate additions to concentrated boiling nitric acid may accelerate the attack on stainless steels, although the results were erratic. Truman(12), in 1954, reported extensive work on the effect of $\mathrm{Cr}^{+6}$ and stated that iron additions had no adverse effect. However, these authors worked with relatively small additions, in the order of $1 \mathrm{~g}$ per liter $\mathrm{Fe}^{+3}$. In the higher concentrations experienced in the Darex system, $\mathrm{Fe}^{+3}$ might be expected to have some deleterious effect. Additional work would be necessary to prove this point.

It is possible that boiling temperatures need not be encountered in the Darex fission-product-recovery system. Lower temperatures would be expected to result in less attack. However, even though stress-corrosion cracking does not seem to be a problem, neither of these stainless steels would be recommended for use with these boiling solutions because of the highly localized attack.

\section{CONCLUSIONS AND RECOMMENDATIONS}

\section{The Sulfex-Thorex Process}

$\mathrm{Ni-o-ne1,} \mathrm{Carpenter} 20 \mathrm{Cb}$, and Illium $\mathrm{R}$ have shown promise as materials of construction for a combined Sulfex-Thorex process dissolver. All three of these alloys are limited to some degree in their corrosion resistance to the decladding or coredissolution solutions.

Ni-o-nel received the most thorough investigation of these three materials as it appeared to have fewer shortcomings. The results of these investigations indicate that a corrosion rate in the neighborhood of 5 mils per month will probably occur upon continuous use of a Ni-o-nel dissolver. If conditions will permit heat treating of this vessel after fabrication, no severe localized attack is expected. The optimum heat treatment is thought to consist of holding in the range of 1850 to $1950 \mathrm{~F}$ for sufficient time to give complete solution of the carbides, and then quenching sufficiently rapidly so that the carbides are retained in solution. Water quenching would be preferred but might be replaced by a rapid air quench. Weldments should be made by the shieldedarc technique, preferably using strips of the parent metal as weld electrodes. Otherwise, Ni-o-nel No. 65 wire can be used for this purpose. 
If it is necessary to use the dissolver in the as-welded condition, severe intergranular attack in the heat-affected areas around weldments is almost a certainty upon exposure to Thorex solutions.

Carpenter $20 \mathrm{Cb}$ is subject to stress-corrosion cracking upon exposure to boiling 4 and $6 \mathrm{M} \mathrm{H}_{2} \mathrm{SO}_{4}$. No heat treatment was found which will completely protect against this. Corrosion rates were not improved by heat treatment. It is true that this cracking is inhibited, especially on submerged surfaces, by cathodic protection from the dissolving fuel elements and by the accumulation of the ions from dissolved stainless . steel in the solution as the decladding proceeds. The usefulness of Carpenter $20 \mathrm{Cb}$ as a dissolver-vessel material needs to be proven by actual dissolution experiments. Such experiments are planned in the future at ORNL.

Illium $\mathrm{R}$ was a reasonably resistant container material except that it was subject to intergranular attack by Thorex solutions due to precipitation of carbides in the heataffected areas around weldments. If stabilized or extra-low-carbon variations of this alloy become available, they should be investigated thoroughly as a possible construction material for a Sulfex-Thorex dissolver.

The Darex-Thorex Process

The possibility of dissolving stainless steel-clad thoria fuel elements by a combination Darex-Thorex process was studied to the extent of actually dissolving 25 Consolidated Edison fuel pins in a dissolver constructed from Titanium 75A. The dissolver survived these dissolutions with very little corrosion except around flange weldments in the vapor phase, and the dissolutions were conducted with very little difficulty.

Some etching-type attack occurred around flange weldments exposed to the vapor from these dissolutions. This seems to have been due partly to contamination of the weldments during welding. Some unresolved questions still remain. These are concerned with the possibility of pitting caused by carry-over of chlorides from the Darex. to the Thorex step. Such pitting has occurred during 1000-hr exposures of titanium coupons to chloride-contaminated Thorex solutions. Also, the advisability of adding aluminum to the Thorex solutions is questionable as the amount of etching occurring in the vapor phase has been shown to be related to the amount of aluminum added to the Initial Thorex solution.

A series of studies is recommended in which thoria dissolutions are conducted eithe $\mathrm{r}$ in the presence of titanium corrosion specimens or in a carefully welded titanium container. These dissolutions should be made without aluminum additions. While titanium corrodes at a rather high rate ( 5 to $10 \mathrm{mils}$ per month) in the Initial Thorex solution when no aluminum is present, the attack is very uniform. It is expected that, as the thorium content of the core-dissolution solution increases, this high rate of attack will diminish rapidly. The net effect may be less localized attack of the container. Such a series of experiments should be conducted before any operating conditions for a Darex-Thorex process are established. 
The Zirflex Process

Evaluations of container materials for a dissolver for the Zirflex process were not carried further than scouting studies in the decladding and core-dissolution systems. The accumulated data from these studies indicated that Haynes 21 was the only material evaluated which had corrosion rates of less than 3 mils per month in both systems.

However, Carpenter $20 \mathrm{Cb}$, Ni-o-nel, and Type 309 or Type $309 \mathrm{~S} \mathrm{Cb}$ stainless steels appear to warrant further investigation. In addition, the vacuum-melted lowcarbon variety of Hastelloy $F$, which was not available for these studies, should be evaluated.

Limited experiments have shown that inhibition of corrosion may be expected from the buildup of zirconium in the system, cathodic protection from the dissolving fuel elements, and intentional addition of such compounds as boron and/or silicon. A much more extensive research program will be necessary before the construction material can be selected.

\section{Possible Use of the Same Vessel for the Zirflex and Sulfex-Thorex Processes}

Judging from the data accumulated during scouting evaluations of materials for construction for the dissolver vessels in the Zirflex and the Sulfex-Thorex processes, only two materials, Carpenter $20 \mathrm{Cb}$ and $\mathrm{Ni}-\mathrm{o}-\mathrm{nel}$ show promise in both systems. However, only five materials were evaluated for both processes.

The outlook for conducting both processes in the same equipment is not good at present. In spite of this, it is possible that another material may be found which will resist the corrosion of both processes. Or, proper heat treatments, inhibitor additions, and other techniques may allow the use of either Carpenter $20 \mathrm{Cb}$ or Ni-o-nel for this purpose. In any event, an extensive program, ultimately involving fuel dis solutions by both processes in the same container, would be necessary before definite recommendations could be made.

\section{The Zircex Process}

Metallographic examination of specimens exposed for 75 cycles to the Zircex hydrochlorination step alone showed that no attack occurred on Illium R, Hastelloy C, or nickel. Only slight attack was found on Inconel and Type S-816 alloy. These materials should be considered if the Zircex process is operated with separate vessels for the hydrochlorination and dissolution, or if the dissolution conditions are made less corrosive. 
The Darex Process

Reasonably extensive experiments have been conducted in which titanium specimens have been exposed to most of the corrosive conditions anticipated in the dissolver and in the feed-adjustment systems of the Darex process. Specimens have included crevices, weldments, stressed areas, and heat has been transferred through some. In addition, the effects of periodic cleaning of the dissolver with boiling $10 \mathrm{w} / \mathrm{o} \mathrm{NaOH}$ and the effects of possible mechanical injury to the surface of titanium have been evaluated.

Practically no attack on titanium has been observed except on heat-transfer surfaces such as might occur if titanium heating coils are used in the dissolver. The most severe attack, in this case, occurs in the fresh dilute aqua regia and amounts to 1.5 to 2 mils per month. This decreases as the ions of dissolved stainless steel accumulate in the solution until, under the condition prevailing at the midpoint of the dissolution, no appreciable attack occurs.

Thus, it appears that, excluding the condition under which hydrochloric acid might accumulate in the absence of nitric acid, titanium can be expected to withstand all normal operating conditions of the Darex dissolver and feed-adjustment systems and it is the construction material of choice.

A preliminary study was sufficient to show that excessive corrosion may result if an existing Type 304 ELC stainless steel pipeline at ORNL is used to transfer solution from the Darex dissolver. Its use is not recommended.

Both Types 304 ELC and 347 stainless steels were severely corroded by solutions representative of the fission-product recovery from the Darex process. The chloride contamination of these solutions seemed to be unrelated to the degree of attack. Apparently the content of stainless steel in these solutions is responsible for the severe knife-line and intergranular types of attack observed on these two alloys, and such solutions probably cannot be handled in conventional stainless equipment.

A 2-yr exposure of stressed and unstressed specimens of Type 347 stainless steel to Darex-derived chloride-contaminated Purex acid systems at room temperature did not produce any attack. Under the conditions of these experiments there was no indication that even large chloride contaminations would be injurious to Type 347 equipment.

\section{ACKNOW LEDGMENT}

Several Battelle staff members were closely associated with these investigations. These include H. A. Pray, W. K. Boyd, W. C. Baytos, J. C. Vargo, W. N. Stiegelmeyer, W. E. Bresler, and T. E. Snoddy.

Excellent cooperation and technical assistance was received from the Chemical Technology Division of ORNL. The authors especially wish to thank W. E. Clark and L. M. Ferris of ORNL and M. G. Fontana of The Ohio State University for their helpful consultation and guidance. 


\section{REFERENCES}

(1) Miller, P. D., Peterson, C. L., White, E. L., Fink, F. W., "Evaluation of Container Materials for Zircex and Darex Nuclear-Fuel-Recovery Processes", BMI-1242 (December 11, 1957).

(2) Peterson, C. L., Miller, P. D., White, E. L., and Clark, W. E., "Materials of Construction for Head-End Processes. Aqueous Reprocessing of Nuclear Fuels", Ind. Eng. Chem., 51, 32-7 (January, 1959).

(3) Peoples, R. S., Fink, F. W., Stewart, O. M., and Braun, W. J., "Corrosion of Type 347 Stainless Steel in the Uranium-Derby Pickle Bath", BMI-927 (July 14, 1954); also, private communication from W. E. Clark, ORNL.

(4) Private communication from N. G. Groves, The Carpenter Steel Co. (February 5, 1959).

(5) Flanary, J. R., Clark, W. E., Goode, J. H., and Kibbey, A. H., "Development of the Sulfex Process for Decladding Stainless-Steel-Clad Power Reactor Fuel Elements With Sulfuric Acid", ORNL-2461, p 12 (March 30, 1959).

(6) Private communication from R. M. Fuller, The International Nickel Company, Inc. (May 25, 1959).

(7) Stough, D. W. , Fink, F. W., and Peoples, R. S. , "The Corrosion of Titanium", TML-57, pp 22-3 (October 29, 1956).

(8) Private communications from W. J. Lewis and G. E. Faulkner, BMI.

(9) Private communication from P. S. Kingsley and R. F. Maness, HAPO (March 30, 1959).

(10) Private communication from W. E. Clark, ORNL.

(11) Shirley, H. T., and Truman, J. E., "Some Factors Affecting the Resistance of Austenitic Chromium-Nickel Steels to Attack by Hot Concentrated Nitric Acid", J. Iron Steel Inst. (London), 171, 354-8 (August, 1952).

(12) Truman, J. E., "Factors Affecting the Testing of Stainless Steels in Boiling

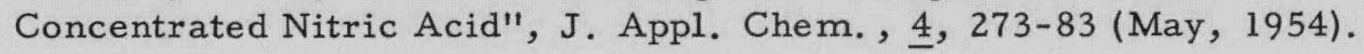


APPENDIX A

HEAT TREATMENT OF CARPENTER $20 \mathrm{Cb}$ 


\section{HEAT TREATMENT OF CARPENTER $20 \mathrm{Cb}$}

The stress cracking of Carpenter $20 \mathrm{Cb}$ in 4 and $6 \mathrm{M} \mathrm{H}_{2} \mathrm{SO}_{4}$ may limit the use of this material for the Sulfex process. Since this alloy showed superior results in the Thorex portion of the recovery process, attempts were made to improve the corrosion resistance in $\mathrm{H}_{2} \mathrm{SO}_{4}$ by various heat treatments.

In the first series of these studies, several specimens of 11- and 16-gage Carpenter $20 \mathrm{Cb}$ were given a 45 -min heat treatment in a nitrogen atmosphere at $2050 \mathrm{~F}$, followed by a water quench. Scale was removed by a $6-\mathrm{hr}$ exposure to boiling $13.0 \mathrm{M}$ $\mathrm{HNO}_{3}, 0.050 \mathrm{M} \mathrm{F}^{-}$. Some of the specimens were stamped with steel figures, and all were exposed for $48 \mathrm{hr}$ to boiling $6 \mathrm{M} \mathrm{H}_{2} \mathrm{SO}_{4}$.

Cracking appeared on the figures stamped after heat treatment but not on figures stamped prior to the treatment. Other cracks, seemingly unassociated with any known deformation of the surface, appeared in both plain and welded coupons.

When these specimens were exposed to boiling $6 \mathrm{M} \mathrm{H}_{2} \mathrm{SO}_{4}$ for an additional $120 \mathrm{hr}$ the cracks became grossly enlarged, as shown in Figures A-1 and A-2. The experiments are summarized in Figure A-3.

In another series of heat treatments, welded specimens of both 11- and 16-gage material were given a solution anneal for $15 \mathrm{~min}$ at $1950 \mathrm{~F}$, followed by a water quench. Part of these specimens, along with specimens in the as-welded condition were stress relieved by heating them to $1650 \mathrm{~F}$ for $10 \mathrm{~min}$ and allowing them to cool slowly in the furnace. All specimens were pickled for $2 \mathrm{hr}$ at $135 \mathrm{~F}$ in a 15 volume per cent $\mathrm{HNO}_{3}-$ 2 volume per cent HF solution and, after thorough washing, were exposed, submerged, in boiling $6 \mathrm{M} \mathrm{H}_{2} \mathrm{SO}_{4}$ for three periods totaling $164 \mathrm{hr}$. The data for these studies are presented in Table $\mathrm{A}-1$. The appearances of the specimens following this exposure are shown in Figure $\mathrm{A}-4$.

Aside from some cracks resulting from poor weldments, no other cracks appeared from the acid exposure, so apparently the stress-relief treatments were successful from this standpoint. However, the general attack on the surfaces was severe and pitting occurred to a great extent on the cut edge and in spots on the surfaces. Some intergranular attack of the weldment was noted. The most resistant specimens were those which did not receive the stress-relief treatment.

Upon evaluating the results from these heat-treatment studies, it was thought that these treatments did not favor the desired formation of niobium carbides. Instead, chromium carbides probably formed and precipitated at the grain boundaries, resulting in areas depleted in chromium with consequent poor corrosion resistance.

Solution anneals of unwelded Carpenter $20 \mathrm{Cb}$ specimens were carried out for 2and $10-\mathrm{hr}$ periods at $1550,1650,1750$, and $1850 \mathrm{~F}$. One specimen from each anneal was water quenched while another was allowed to cool in the furnace with the heating elements turned off and the door open. Following a $\mathrm{HNO}_{3}-\mathrm{HF}$ pickle to remove scale, and a thorough washing, these specimens were exposed, submerged, in boiling 

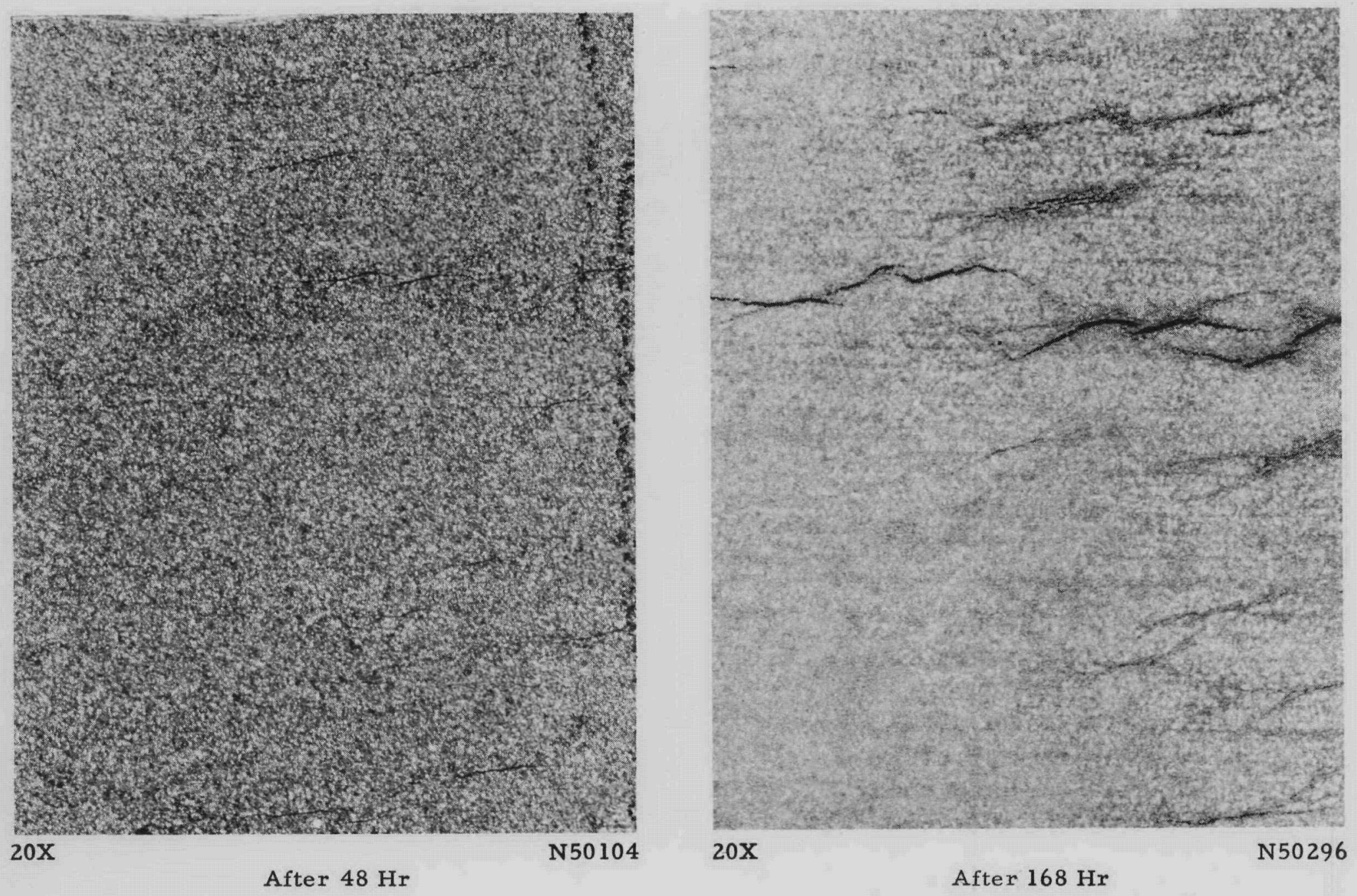

FIGURE A-1. DEVELOPMENT OF CRACKING IN UNWELDED CARPENTER $20 \mathrm{Cb}$ EXPOSED TO BOILING $6 \mathrm{MH}_{2} \mathrm{SO}$

Approximately the same area of one specimen is shown at two different times. 

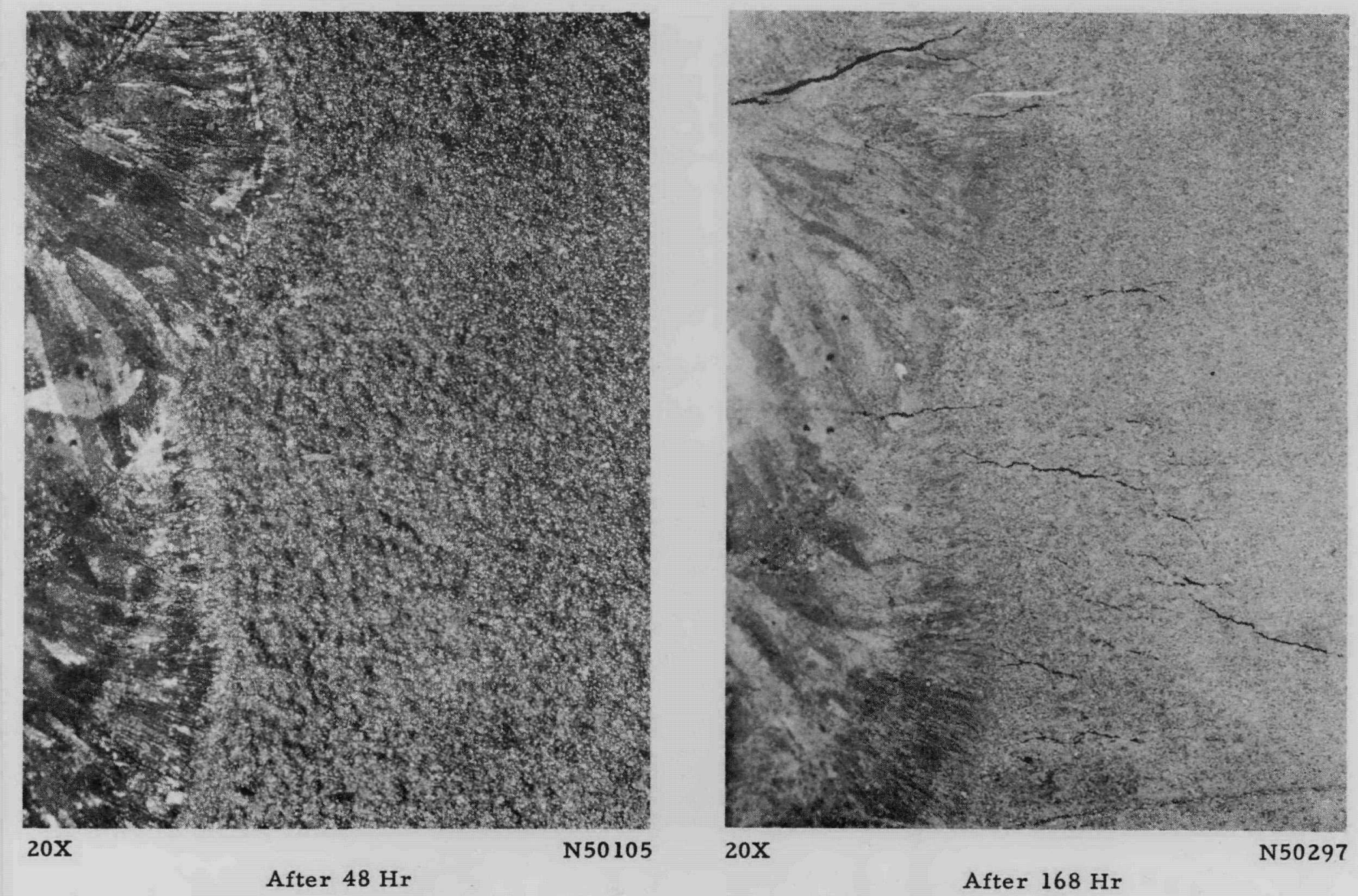

FIGURE A-2. DEVELOPMENT OF CRACKING IN WELDED CARPENTER $20 \mathrm{Cb}$ EXPOSED TO BOILING $6 \mathrm{M} \mathrm{H}_{2} \mathrm{SO}_{4}$ Approximately the same area of one specimen is shown at two different times. 
WITH NO HEAT TREATMENT: SPECIMENS EXHIBIT CRACKING AROUND IMPRINTED NUMBERS-

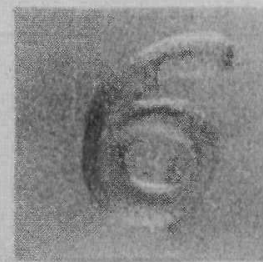

$10-3$ HOUR

PERIODS

$(24 x)$

WITH HEAT TREATMENT: SPECIMENS EXHIBIT CRACKING AROUND IMPRINTED

NUMBERS ONLY IF IMPRINTED AFTER HEAT TREATMENT-

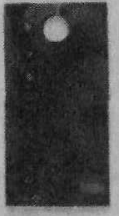

IMPRINTED BEFORE

HEAT TREATMENT

(168 HOURS)

IMPRINTED AFTER

HEAT TREATMENT

(168 HOURS)

...BUT, SPECIMENS EXHIBIT SOME CRACKING ON SURFACES AND WELDMENTS

IN AREAS WHERE NO SURFACE DEFORMATION WAS KNOWN TO OCCUR.
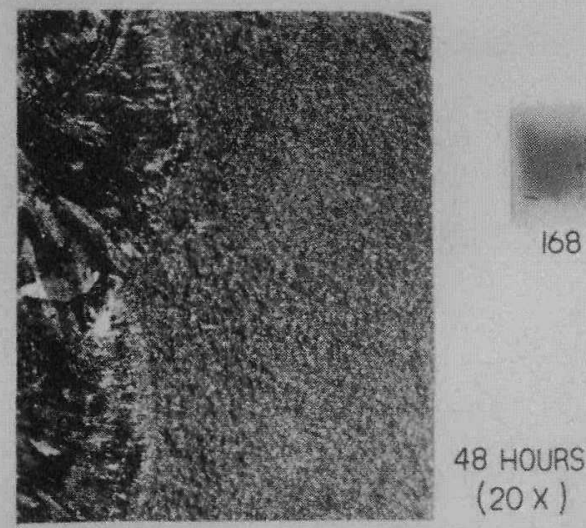

(20x)

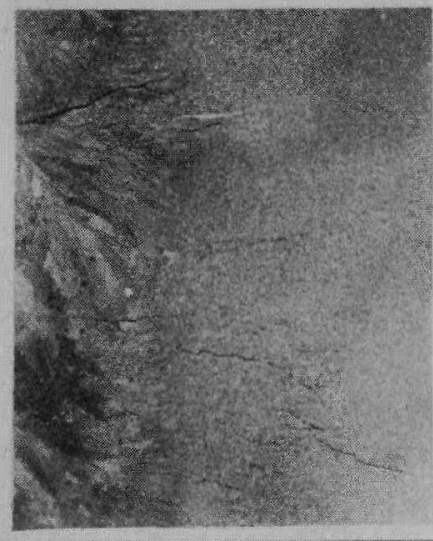

168 HOURS

(20X)

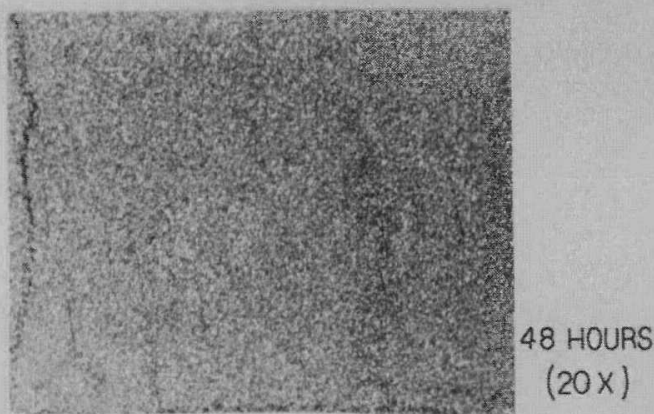

N51086

FIGURE A-3. EFFECTS OF HEAT TREATMENT ON CARPENTER $20 \mathrm{Cb}$ IN BOILING SULFEX ( $6 \mathrm{M} \mathrm{H}_{2} \mathrm{SO}_{4}$ ) SOLUTIONS

Specimens were heat treated $45 \mathrm{~min}$ at $2050 \mathrm{~F}$ and water quenched. 
TABLE A-1. THE EFFECT OF SOLUTION-ANNEAL AND STRESS-RELIEF HEAT TREATMENTS ON THE CORROSION RESISTANCE OF WELDED CARPENTER $20 \mathrm{Cb}$ SPECIMENS SUBMERGED IN BOILING $6 \mathrm{M} \mathrm{H}_{2} \mathrm{SO}_{4}$

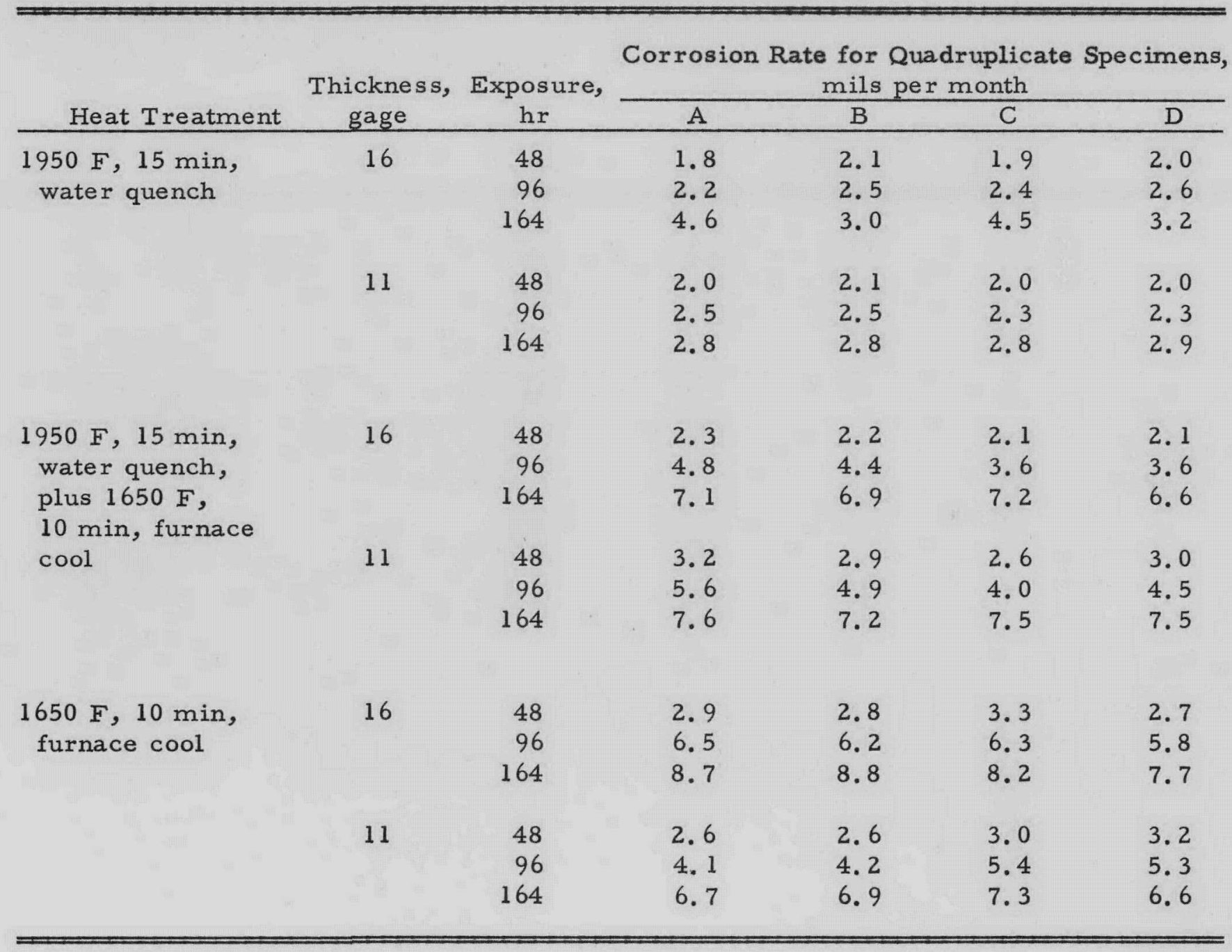


HEAT THICKNESS, EXPOSURE, TREATMENT GAGE HOURS

CORROSION RATE, MILS PER MONTH

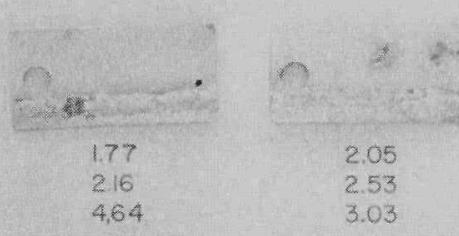

6.8

2.04

2.50

2.80

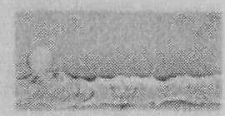

2.28

4.78

7.07

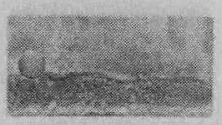

3.23

563

7.64

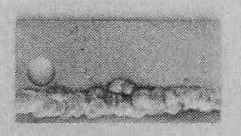

2.94

6.54

8.73

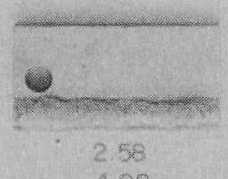

4.08

6.68

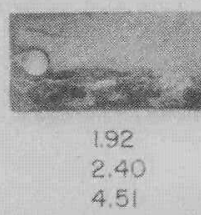

9

(2)

2.07
2.52
2.80

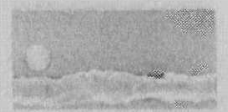

2.19

4.41

6.92
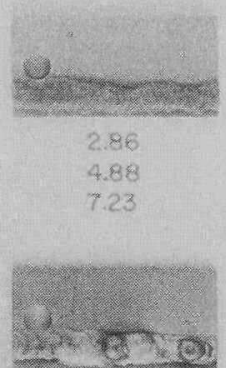

281

281
6.22
8.77

8.77

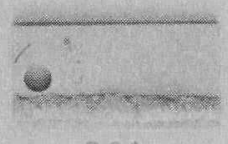

2.64

4.16
2.03

2.28

282

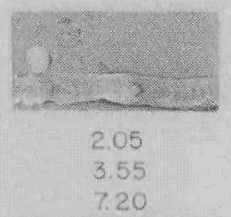

7. 20
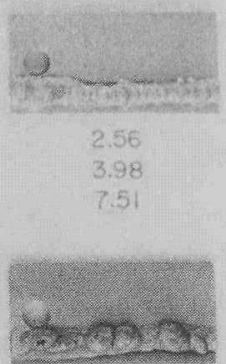

3.29

6.32

8.22

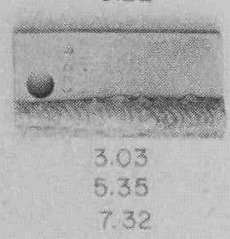

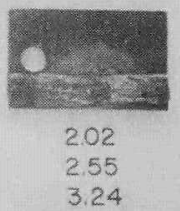

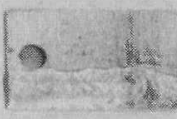

2.03

232

2.91
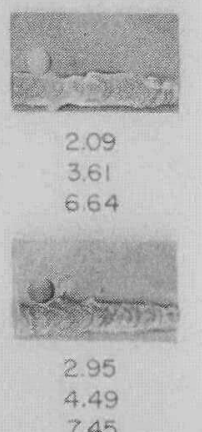

7.45

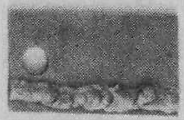

2.74

5.78

7.71

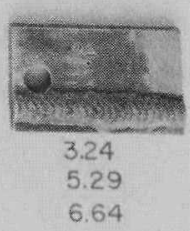

N53685

FIGURE. A 4. THE EFFECT OF SOLUTION-ANNEAL AND STRESS-RELIEF HEAT TREATMENTS ON THE CORROSION RESISTANCE OF WELDED CARPENTER $20 \mathrm{Cb}$ SPECIMENS SUBMERGED IN BOILING $6 \mathrm{M} \mathrm{H}_{2} \mathrm{SO}_{4}$ 
$6 \mathrm{M} \mathrm{H}_{2} \mathrm{SO}_{4}$. Weight losses were measured after 96 and $192 \mathrm{hr}$ of exposure. The corrosion rates based on these weight losses are given in Table A-2 along with values from studies reported earlier for comparison.

Water quenching or furnace cooling had little effect on the corrosion rates. In most cases, the longer annealing time resulted in higher rates. The best corrosion resistance was shown by the pieces annealed at the highest temperature (1950). In general, the rates are higher than those obtained upon similar exposure of the as-received material.

Cracking was not observed upon inspection after $96 \mathrm{hr}$. However, it was observed to a slight extent at the end of $192 \mathrm{hr}$ around figures stamped on the specimens following the 96-hr examination. Considerable pitting occurred, being especially severe on specimens treated at the lower temperatures.

Thinking that the pitting might have resulted from surface effects produced by heat treatment, two of the specimens given the higher annealing temperatures were resurfaced to remove all traces of corrosion. These were exposed to boiling $6 \mathrm{M} \mathrm{H}_{2} \mathrm{SO}_{4}$ for $96 \mathrm{hr}$. The corrosion rates remained high and the pitting reoccurred, showing that this is not due to a surface effect.

It has been concluded that the optimum heat treatment for minimizing stress corrosion cracking of Carpenter $20 \mathrm{Cb}$ in boiling Sulfex solutions consists of holding the alloy in the 1950 to $1975 \mathrm{~F}$ range for sufficient time to give complete solution of the carbides, followed by a rapid quench.

TABLE A-2. CORROSION RATES FOR UNWELDED 16-GAGE CARPENTER $20 \mathrm{Cb}$ SPECIMENS SUBMERGED IN BOILING $6 \mathrm{M} \mathrm{H}_{2} \mathrm{SO}_{4}$ AFTER VARIOUS SOLUTION-ANNEAL HEAT TREATMENTS

\begin{tabular}{|c|c|c|c|c|c|}
\hline \multirow{3}{*}{$\begin{array}{l}\text { Annealing } \\
\text { Temper- } \\
\text { ature, } F\end{array}$} & \multirow[b]{3}{*}{$\begin{array}{c}\text { Exposure, } \\
\mathrm{hr}\end{array}$} & \multicolumn{4}{|c|}{ Corrosion Rate, mils per month } \\
\hline & & \multicolumn{2}{|c|}{ Specimen Annealed $2 \mathrm{Hr}$} & \multicolumn{2}{|c|}{ Specimen Annealed $10 \mathrm{Hr}$} \\
\hline & & $\begin{array}{c}\text { Water } \\
\text { Quenched }\end{array}$ & $\begin{array}{c}\text { Furnace } \\
\text { Cooled }\end{array}$ & $\begin{array}{c}\text { Water } \\
\text { Quenched }\end{array}$ & $\begin{array}{l}\text { Furnace } \\
\text { Cooled (a) }\end{array}$ \\
\hline \multirow[t]{2}{*}{1550} & 96 & 6.8 & 14 & 12 & 17 \\
\hline & 192 & 9.9 & 14 & 11 & 17 \\
\hline \multirow[t]{2}{*}{1650} & 96 & 4.4 & 6.6 & 11 & 9.5 \\
\hline & 192 & 8.1 & 10 & 11 & 12 \\
\hline \multirow[t]{2}{*}{1750} & 96 & 3.8 & 3.4 & 7.6 & 6.4 \\
\hline & 192 & 7.2 & 6. $1(\mathrm{~b})$ & 5.8 & 9.6 \\
\hline \multirow[t]{2}{*}{1850} & 96 & 3.5 & 3.6 & 5.8 & 5.7 \\
\hline & 192 & 6.4 & $7.3^{(c)}$ & 5.4 & 9.3 \\
\hline
\end{tabular}

(a) Cooled in furnace with power off and door open.

(b) Additional $96-\mathrm{hr}$ exposure after resurfacing gave 8.9 mils per month.

(c) Additional $96-\mathrm{hr}$ exposure after resurfacing gave 7.0 mils per month. 
-

. 
APPENDIX B

HEAT TREATMENT OF NI-O-NEL 


\section{APPENDIX B}

\section{HEAT TREATMENT OF NI-O-NEL}

Several heat treatments for Ni-o-nel were studied in an effort to eliminate or, at least, minimize the intergranular and knife-line attacks which occur upon exposure to Thorex solutions. The first of these was performed on some of the specimens which were undergoing intergranular attack during the cyclic studies.

These previously welded specimens were heat treated at $1850 \mathrm{~F}$ for $30 \mathrm{~min}$ and quenched in air. Following this, they were machined to give new, corrosion-free surfaces and were exposed to boiling Initial and Final Thorex solutions containing added aluminum.

The data obtained from these experiments are shown in Table B-1 and plotted in Figure B-1. Inspection after $288 \mathrm{hr}$ of exposure showed the surfaces to be in very good condition. A slight superficial attack at the edge of the weldment of a specimen which had been submerged in Initial Thorex solution was the only indication of attack. Metallographic examination of sections cut from the specimens following the 500-hr inspection showed intergranular attack, especially pronounced at the edge of the weldments, on specimens exposed to Initial Thorex solution. Average penetration of this attack over the surface was about $2 \mathrm{mils}$, while a maximum of $5 \mathrm{mils}$ was observed in isolated spots along the edges of the weldments. One of the areas of maximum penetration is shown in Figure B-2.

No preferential attack at the edges of the weldments was noted on specimens exposed for $500 \mathrm{hr}$ to boiling Final Thorex solution. A slight microetch and superficial intergranular attack was all that could be observed on one of these specimens.

At the end of $1000 \mathrm{hr}$, specimens exposed to Initial Thorex solutions were again sectioned. The weldments and surfaces were roughened as shown in Figure B-3, but the selective attack at the edge of the weldment was not serious.

There are two factors contributing to the change in corrosion rates following $500 \mathrm{hr}$. First, the specimens were sectioned at this point, thus exposing smaller areas with newly cut edges during subsequent periods. Secondly, the first $500 \mathrm{hr}$ of exposure was conducted in Teflon-lined steel units, the second, in small Kel-F bottles. Not only was a fresh solution and a different surface area to solution volume used, but, as will be shown later, the opportunity for hexavalent chromium to form was probably enhanced during the second $500-\mathrm{hr}$ period. Considering all these factors, these specimens showed low corrosion rates and are among the most resistant of any that were evaluated.

Several other heat treatments at 1650,1850 , and $1950 \mathrm{~F}$ were studied. Since heat treating and quenching a vessel after its fabrication involves considerable difficulty, some of the heat treatments were made prior to welding in the hope that the heataffected zone resulting from subsequent welding operations would remain more stabilized.

The data for the specimens which were heat treated at 1650 and $1850 \mathrm{~F}$ are shown in Table B-2 and plotted in Figure B-4. As noted in the table, the weldments on one set 
TABLE B-1. CORROSION RATES FOR WELDED STABILIZED NI-O-NEL(a) SUBMERGED IN BOILING THOREX (0.20 M Al+3 ADDED) SOLUTIONS

\begin{tabular}{|c|c|c|c|c|}
\hline \multirow{3}{*}{$\begin{array}{l}\text { Exposure, } \\
\text { hr }\end{array}$} & \multicolumn{4}{|c|}{$\begin{array}{c}\text { Corrosion Rate for Duplicate(b) Specimens, } \\
\text { mlls per month }\end{array}$} \\
\hline & \multicolumn{2}{|c|}{ Initial Thorex $(\mathrm{c})$} & \multicolumn{2}{|c|}{ Final Thorex(c) } \\
\hline & $\mathrm{A}$ & $\mathrm{B}$ & $\mathrm{A}$ & $\mathrm{B}$ \\
\hline 24 & 1.3 & 1.3 & 0.53 & 0.49 \\
\hline 96 & 1.1 & 1.1 & 0.41 & 0.40 \\
\hline 192 & 0.82 & 0.82 & 0.39 & 0.38 \\
\hline 288 & 0.67 & 0.66 & 0.38 & 0.38 \\
\hline 500 & 0.67 & 0.66 & 0.38 & 0.37 \\
\hline $745(d)$ & 1.1 & 1. 1 & 0.40 & 0.40 \\
\hline 1000 & 1.2 & 1.2 & 0.42 & 0.43 \\
\hline
\end{tabular}

(a) Specimens were heat treated for $0.5 \mathrm{hr}$ at $1850 \mathrm{~F}$, after welding, air quenched, and surface ground.

(b) A and B represent duplicate specimens exposed together.

(c) Solution compositions: Initial Thorex $13.0 \mathrm{M} \mathrm{HNO}_{3}, 0.050 \mathrm{MF}^{-}$ Final Thorex 8.5 $\mathrm{M} \mathrm{HNO}_{3}, 0.050 \mathrm{M} \mathrm{F}^{-}, 1.0 \mathrm{M}$ Th( $\left.\mathrm{NO}_{3}\right)_{4}$.

(d) Specimens were sectioned at 500-hr point. Further rates are adjusted for remaining pieces of specimens. 


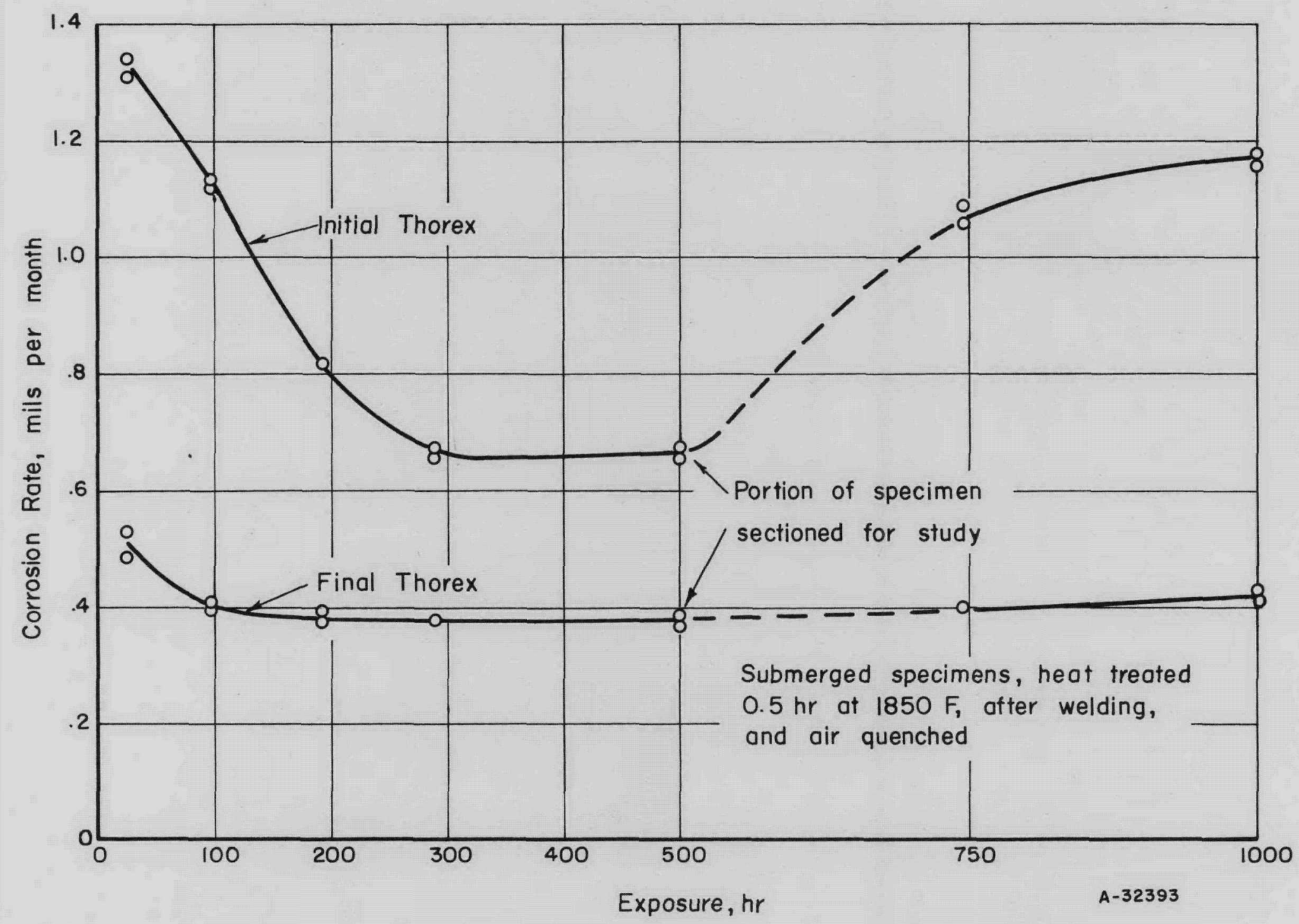

FIGURE B-1. CORROSION RATES FOR WELDED STABILIZED NI-O-NEL SUBMERGED IN BOILING THOREX SOLUTIONS WITH $0.20 \mathrm{M} \mathrm{Al}^{+3}$ 


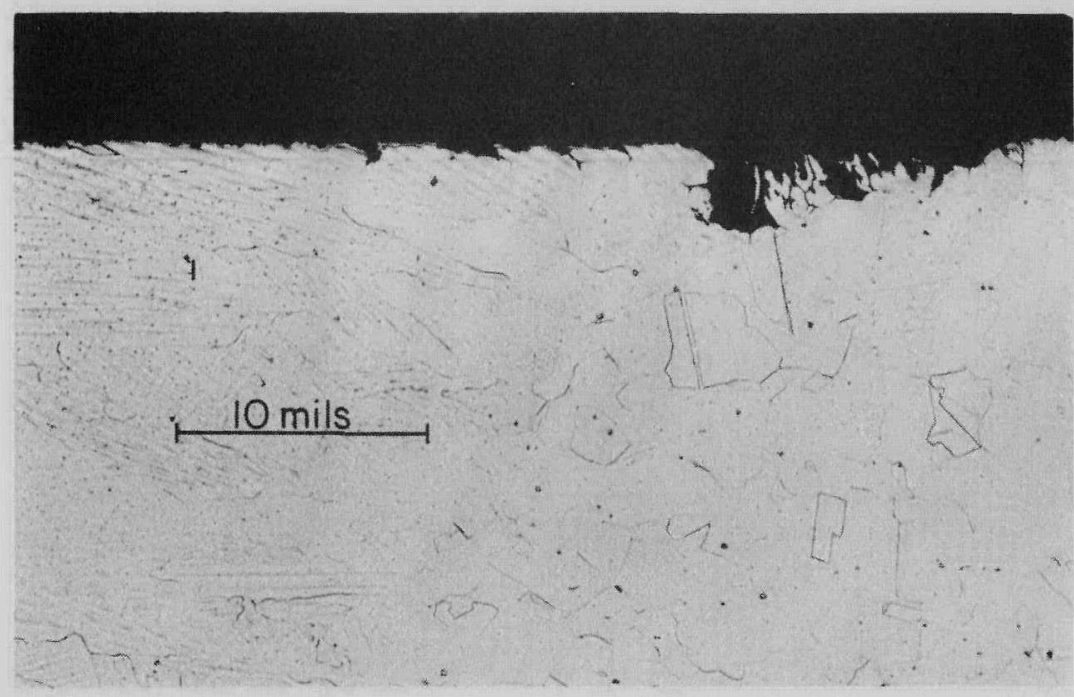

FIGURE B-2. SELECTIVE ATTACK OF WELDED STABILIZED NI=0-NEL FOLLOWING 500 HR OF EXPOSURE TO BOILING INITIAL THOREX SOLUTION WITH $0.20 \mathrm{M} \mathrm{Al}^{+3}$

Maximum penetration occurred along the edges of the weldments, as shown here.

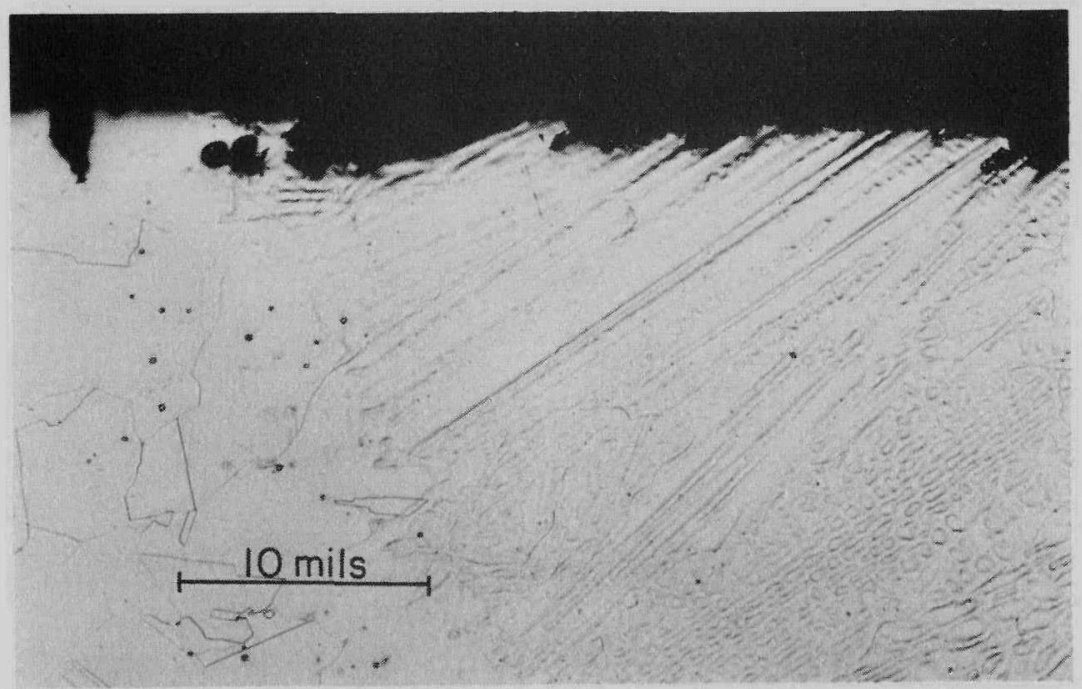

FIGURE B-3. SURFACE OF WELDED STABILIZED NI-O-NEL FOLLOWING 1000 HR OF EXPOSURE TO BOILING INITIAL THOREX SOLUTION WITH $0.20 \mathrm{M} \mathrm{Al}^{+3}$

The selective attack at the edge of the weldment is not serious. 
TABLE B-2. CORROSION RATES FOR WELDED STABILIZED NI-O-NEL SUBMERGED IN BOILING INITIAL THOREX $\left(0.20 \mathrm{M} \mathrm{Al}^{+3}\right.$, ADDED) SOLUTIONS(a)

\begin{tabular}{|c|c|c|c|c|}
\hline \multirow[b]{2}{*}{ Heat Treatment } & \multirow{2}{*}{$\begin{array}{l}\text { Exposure } \\
\mathrm{hr}\end{array}$} & \multicolumn{2}{|c|}{$\begin{array}{l}\text { Corrosion Rate } \\
\text { for Duplicate(b) } \\
\text { Specimens, } \\
\text { mils per } \\
\text { month }\end{array}$} & \multirow{2}{*}{$\begin{array}{c}\text { Observations After } \\
\text { Exposure }\end{array}$} \\
\hline & & $\mathrm{A}$ & B & \\
\hline $\begin{array}{l}1650 \mathrm{~F}, 1.0 \mathrm{hr} \text {, air quenched } \\
\text { after welding with coated } \\
\text { electrode }\end{array}$ & $\begin{array}{r}24 \\
96 \\
192 \\
288 \\
500\end{array}$ & $\begin{array}{r}2.6 \\
3.0 \\
4.4 \\
3.5 \\
12\end{array}$ & $\begin{array}{r}2.6 \\
3.4 \\
5.9 \\
5.0 \\
14\end{array}$ & $\begin{array}{l}\text { Surfaces severely } \\
\text { corroded; weldments } \\
\text { completely disinte- } \\
\text { grated }\end{array}$ \\
\hline $\begin{array}{l}1650 \mathrm{~F}, 24 \mathrm{hr} \text {, air quenched } \\
\text { after welding with coated } \\
\text { electrode }\end{array}$ & $\begin{array}{r}24 \\
96 \\
192 \\
288 \\
500\end{array}$ & $\begin{array}{r}2.5 \\
2.5 \\
4.1 \\
3.5 \\
11\end{array}$ & $\begin{array}{r}2.3 \\
2.5 \\
4.0 \\
3.4 \\
12\end{array}$ & $\begin{array}{l}\text { Surfaces severely } \\
\text { corroded; weldments } \\
\text { perforated }\end{array}$ \\
\hline $\begin{array}{l}1650 \mathrm{~F}, 2.0 \mathrm{hr} \text {, air quenched } \\
\text { before welding with filler } \\
\text { strip }\end{array}$ & $\begin{array}{r}24 \\
96 \\
192 \\
288 \\
500\end{array}$ & $\begin{array}{l}1.4 \\
1.3 \\
1.4 \\
1.5 \\
2.5\end{array}$ & $\begin{array}{l}1.4 \\
1.3 \\
1.4 \\
1.5 \\
2.5\end{array}$ & $\begin{array}{l}\text { General attack over } \\
\text { surface; moderate } \\
\text { attack on weldments }\end{array}$ \\
\hline $\begin{array}{l}1650 \mathrm{~F}, 10.0 \mathrm{hr} \text {, air quenched } \\
\text { before welding with filler strip }\end{array}$ & $\begin{array}{r}24 \\
96 \\
192 \\
288 \\
500\end{array}$ & $\begin{array}{l}1.5 \\
1.2 \\
1.2 \\
1.2 \\
1.7\end{array}$ & $\begin{array}{l}1.5 \\
1.2 \\
1.2 \\
1.3 \\
1.8\end{array}$ & Ditto \\
\hline $\begin{array}{l}1850 \mathrm{~F}, 0.5 \mathrm{hr} \text {, air quenched } \\
\text { before welding with filler strip }\end{array}$ & $\begin{array}{r}24 \\
96 \\
192 \\
288 \\
500 \\
755 \\
1000\end{array}$ & $\begin{array}{l}1.8 \\
1.4 \\
1.0 \\
0.90 \\
1.1 \\
1.1 \\
1.2\end{array}$ & $\begin{array}{l}1.7 \\
1.4 \\
1.1 \\
0.97 \\
1.1 \\
1.2 \\
1.2\end{array}$ & $\begin{array}{l}\text { Slight-over-all attack; } \\
\text { intergranular attack } \\
\text { in heat-affected areas } \\
\text { along weldments }\end{array}$ \\
\hline $\begin{array}{l}1850 \mathrm{~F}, 0.5 \mathrm{hr} \text {, air quenched } \\
\text { before welding with No. } 65 \text { wire }\end{array}$ & $\begin{array}{r}24 \\
96 \\
192 \\
288 \\
500 \\
755 \\
1000\end{array}$ & $\begin{array}{l}1.8 \\
1.4 \\
1.2 \\
0.94 \\
1.1 \\
1.1 \\
1.2\end{array}$ & $\begin{array}{l}1.1 \\
0.85 \\
0.88 \\
0.81 \\
1.1 \\
1.1 \\
1.2\end{array}$ & Ditto \\
\hline
\end{tabular}

(a) Composition: $13.0 \mathrm{M} \mathrm{HNO}_{3}, 0.05 \mathrm{MF}^{-}$. Fresh solutions used after $288 \mathrm{hr}$.

(b) A and B represent duplicate specimens in same flask. 


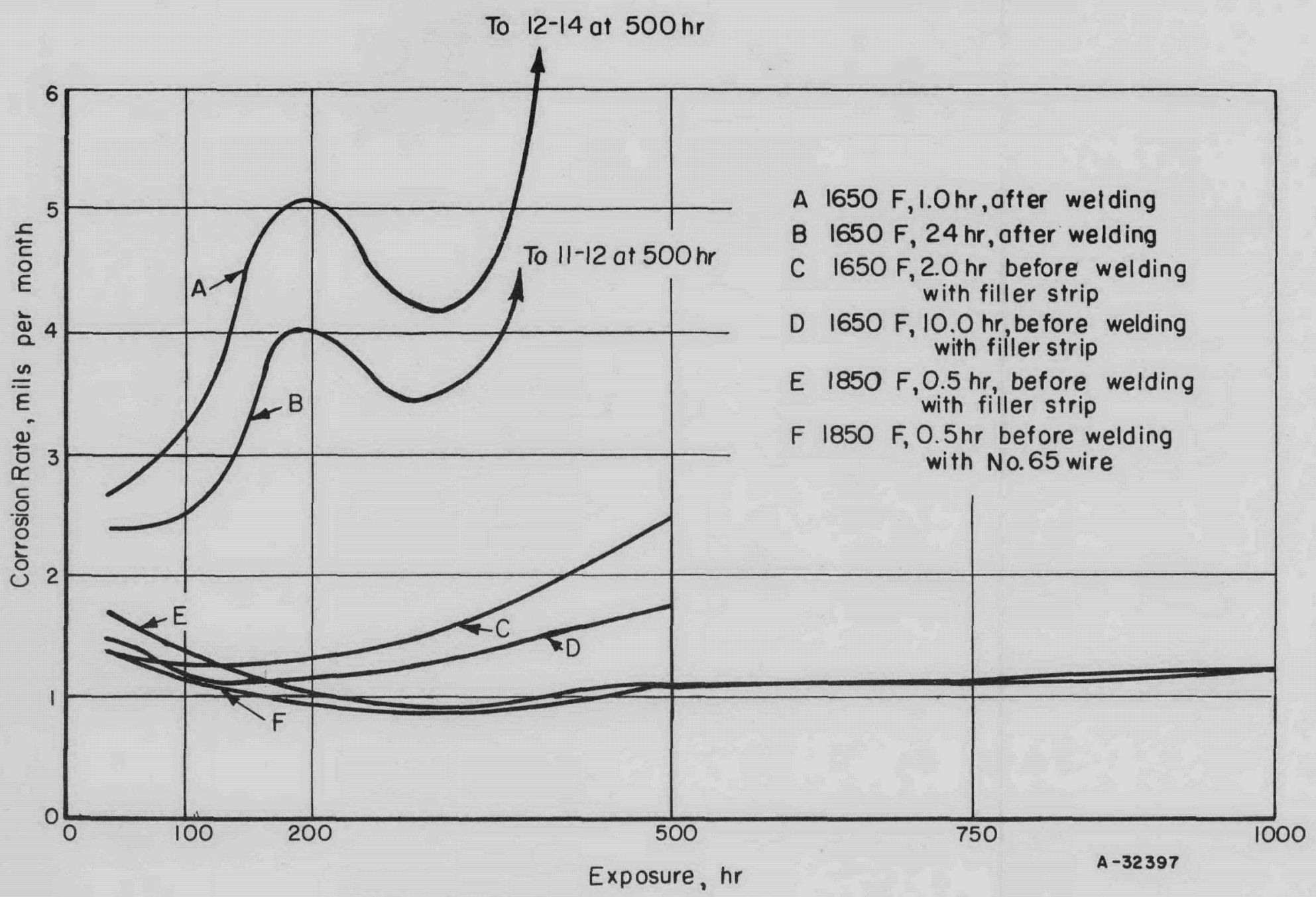

FIGURE B-4. CORROSION RATES FOR WELDED STABILIZED NI-O-NEL WITH VARIOUS HEAT TREATMENTS UPON SUBMERSION IN BOILING INITIAL THOREX SOLUTIONS WITH $0.20 \mathrm{M} \mathrm{Al}^{+3} \mathrm{ADDED}$ 
of specimens treated at $1650 \mathrm{~F}$ after welding disintegrated while those on the other set were badly perforated. These weldments had been made with flux-coated electrodes. The Ni-o-nel welding electrodes in this case were stabilized with niobium rather than titanium to protect against volatilization of the stabilizing agent during welding. The producer was aware of other cases of selective attack by various process solutions on weldments made with this type electrode and now recommends welding by the inert-gas shielding technique using Ni-o-nel No. 65 wire. This wire is titanium stabilized and has about the same composition as the parent metal.

Specimens were heat treated for 2 and $10 \mathrm{hr}$ at $1650 \mathrm{~F}$ prior to welding. Upon evaluating these specimens by exposure to boiling Initial Thorex solutions, it was found that the entire surface excluding the weldment had been sensitized. Corrosion was severe and general over this surface. Some attack also appeared in the weldments.

Heat treatment at $1850 \mathrm{~F}$ prior to welding did not produce this general surface sensitization. However, the welding operation produced sensitized zones in narrow bands down each side of the weld bead. Intergranular attack was severe in these bands. Specimens from the 1650 and $1850 \mathrm{~F}$ heat treatments are compared in Figure B-5.

Weldments made with Ni-o-nel wire were compared with weldments made with filler strip cut from the parent metal while evaluating the effectiveness of heat treating at $1850 \mathrm{~F}$ prior to welding. Weldments made both ways were fairly resistant but the final appearances after exposure of the filler-strip welds were slightly superior.

It thus appeared that, while heat treatment before welding may be preferable from the standpoint of fabrication, heat treatment after welding imparted greater corrosion resistance. Additionally, treatment at $1850 \mathrm{~F}$ was much better than at $1650 \mathrm{~F}$.

A final series of heat-treatment studies was made at 1850 and $1950 \mathrm{~F}$. The schedule for these and the corrosion rates upon evaluation in boiling Initial Thorex solutions are given in Table B-3.

The lack of agreement in corrosion rates between duplicate specimens is related to an interesting observation. For some time, similar reflux studies with boiling Thorex solutions were carried out in equipment constructed from Teflon-lined steel pipe. The first two assemblies were constructed from proprietary material lined with Teflon which contained incorporated carbon black, added to improve extrusion and forming characteristics. Later on, other assemblies were constructed using a white, virgin Teflon lining. For the sake of expression, these are referred to as the black containers and the white containers, respectively. One set (A) of specimens from each heat treatment was exposed in a black container, and the duplicate set (B) was exposed in a white one. The examination after $96 \mathrm{hr}$ showed Set (A) to be shiny with little localized attack. Set (B), however, was covered with a tan stain, and intergranular attack was seen along the weldments. The solution from the black container was greenish black in color, that from the white container was orange. The sets of specimens were reversed in the containers for the rest of the exposure periods. The tan stain and intergranular attack then appeared on Set(A). Solutions from the white container were always orange after an exposure period. Analysis of one of these solutions showed that about half of the chromium present as a corrosion product was in the hexavalent state. The concentration of hexavalent chromium in the greenish-black solution from the black container was very low. 
B -8

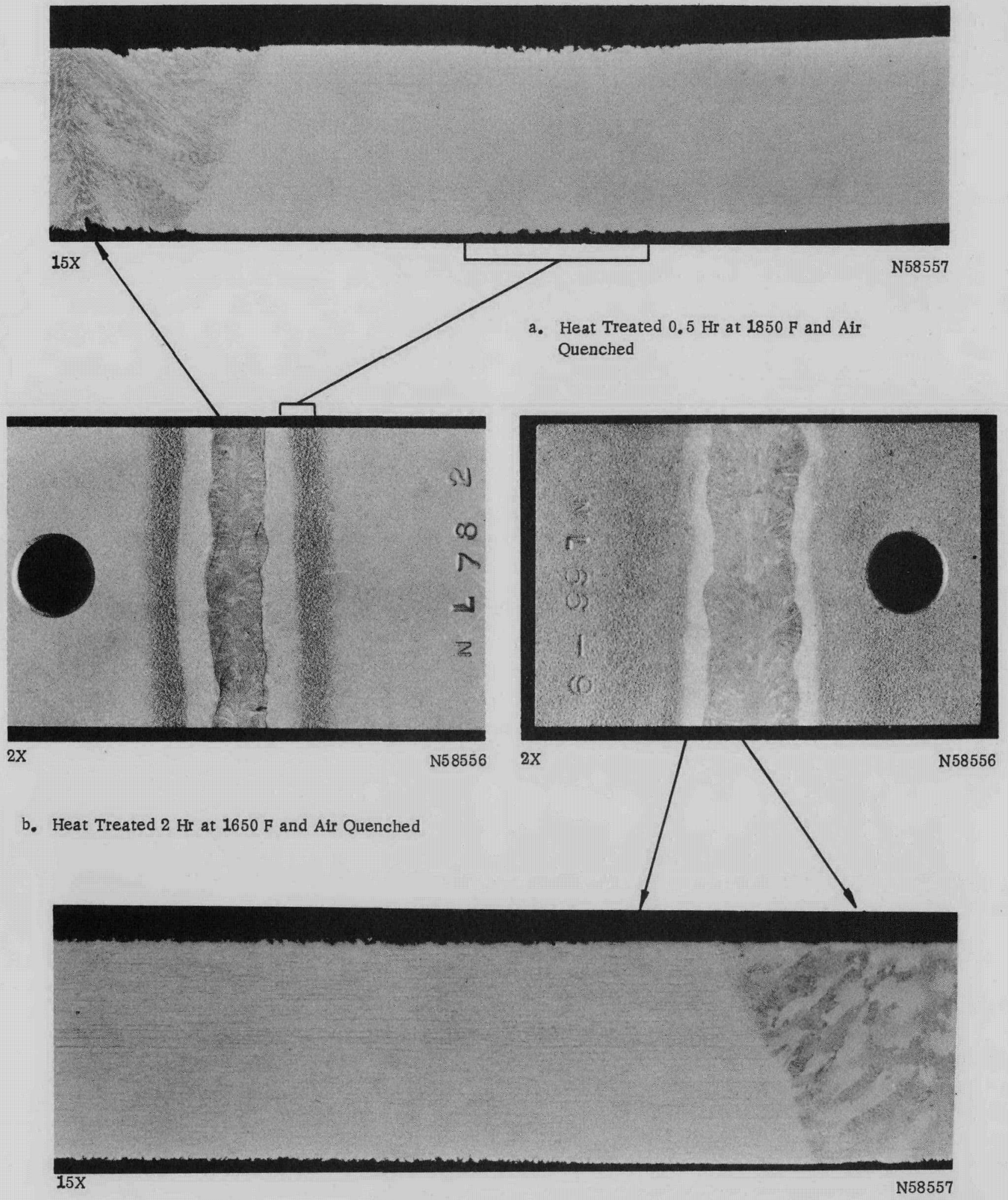

FIGURE B-5. STABILIZED NI-O-NEL, HEAT TREATED BEFORE WELDING WITH FILLER STRIPS, AFTER EXPOSURE TO BOILING INITIAL THOREX SOLUTIONS 
TABLE B-3. CORROSION RATES FOR WELDED STABILIZED NI-O-NEL SPECIMENS SUBMERGED IN BOILING INITIAL THOREX (0.20 $\mathrm{M} \mathrm{Al}^{+3}$ ADDED) SOLUTIONS(a)

\begin{tabular}{|c|c|c|c|c|c|}
\hline \multirow[b]{3}{*}{ Heat Treatment } & \multirow{3}{*}{$\begin{array}{c}\text { Exposure, } \\
\text { hr }\end{array}$} & \multicolumn{4}{|c|}{$\begin{array}{c}\text { Corrosion Rate for Duplicate } \\
\text { Specimens, mils } \\
\text { per month }\end{array}$} \\
\hline & & \multicolumn{2}{|c|}{ Air Quenched } & \multicolumn{2}{|c|}{ Water Quenched } \\
\hline & & $\mathrm{A}$ & $\mathrm{B}$ & A & $\mathrm{B}$ \\
\hline \multirow{7}{*}{$\begin{array}{l}1850 \mathrm{~F}, 0.5 \mathrm{hr} \text {, after } \\
\text { welding with filler } \\
\text { strip }\end{array}$} & 24 & 1.6 & 1.7 & 1.6 & 1. 8 \\
\hline & 96 & 1.2 & 1.4 & 1.2 & 1. 3 \\
\hline & 192 & 1.1 & 1.7 & 1.1 & 1. 4 \\
\hline & 288 & 1.1 & 1.7 & 1.1 & 1.3 \\
\hline & 500 & 1.4 & 1.9 & 1.2 & 1.5 \\
\hline & 755 & 4.0 & 1.7 & 2.7 & 1.4 \\
\hline & 1000 & 6.6 & 2.1 & 4.6 & 1.6 \\
\hline \multirow{7}{*}{$\begin{array}{l}1850 \mathrm{~F}, 2.25 \mathrm{hr} \text {, after } \\
\text { welding with filler } \\
\text { strip }\end{array}$} & 24 & 1.6 & 1.8 & 1.5 & 1. 7 \\
\hline & 96 & 1.2 & 1.4 & 1.2 & 1.3 \\
\hline & 192 & 1.1 & 1.7 & 1.1 & 1.3 \\
\hline & 288 & 1.1 & 1.6 & 1.1 & 1.3 \\
\hline & 500 & 1.4 & 1. 8 & 1.2 & 1.4 \\
\hline & 755 & 3.8 & 1.7 & 2.6 & 1. 3 \\
\hline & 1000 & 6.2 & 2.0 & 4.4 & 1.5 \\
\hline \multirow{7}{*}{$\begin{array}{l}1850 \mathrm{~F}, 10.0 \mathrm{hr} \text {, after } \\
\text { welding with filler } \\
\text { strip }\end{array}$} & 24 & 1.6 & 1.7 & -- & -- \\
\hline & 96 & 1.2 & 1.3 & -- & -- \\
\hline & 192 & 1.1 & 1.5 & -- & -- \\
\hline & 288 & 1.0 & 1.5 & -- & -- \\
\hline & 500 & 1.3 & 1.6 & -. & -- \\
\hline & 755 & 3.4 & 1.5 & -- & -- \\
\hline & 1000 & 6.0 & 1.8 & -- & -- \\
\hline \multirow{7}{*}{$\begin{array}{l}1950 \mathrm{~F}, 2.0 \mathrm{hr} \text {, after } \\
\text { welding with filler } \\
\text { strip }\end{array}$} & 24 & 1.7 & 1.9 & -. & - \\
\hline & 96 & 1.2 & 1.3 & -- & -- \\
\hline & 192 & 1.1 & 1.5 & -- & -- \\
\hline & 288 & 1.0 & 1.5 & -- & -- \\
\hline & 500 & 1.2 & 1.6 & -- & -- \\
\hline & 755 & 3.3 & 1.5 & -- & -- \\
\hline & 1000 & 5.7 & 1.8 & -- & -- \\
\hline
\end{tabular}

(a) Initial Thorex solution composition: $13.0 \mathrm{M} \mathrm{HNO}_{3}, 0.05 \mathrm{M} \mathrm{F}^{-}$.

(b) A and $\mathrm{B}$ represent duplicate specimens exposed in different reflux units. 
A plausible explanation of the se observations is that a $13 \mathrm{M} \mathrm{HNO}_{3}$ solution gradually builds up in chromium as corrosion takes place. It has been established that hexavalent chromium accelerates the corrosion of stainless steels in strong nitric acid. (12)* It is thought that the carbon black was leached from the Teflon in the black container and served as a reducing agent, keeping the chromium in the tervalent state. (The wall of this container became progressively lighter in color.)

In any event, Set (A) showed a much higher corrosion rate than Set (B). In addition, intergranular attack was prevalent over the entire surfaces of the specimens in Set (A). The intergranular attack originally on Set (B) was largely obliterated by further general corrosion. Sections of two similar specimens exposed in the presence of $\mathrm{Cr}^{+3}$ and $\mathrm{Cr}^{+6}$ are shown in Figure $\mathrm{B}-6$.

The exposure conditions for Set (B) (in the virtual absence of hexavalent chromium for the last $905 \mathrm{hr}$ ) are thought to be more representative of actual reprocessing, since peroxides from radiolytic reactions would probably hinder the buildup of hexavalent chromium. Specimens from this set were bright and showed little intergranular attack. There was some pitting of the weldments. Measurements of the intergranular penetrations for some specimens are shown in Table B-4.

In Figure B-7, the ranges of corrosion rates based on weight changes are shown for the two sets of specimens. In the presence of trivalent chromium, the choice of heat treatments did not produce such significant differences as in the presence of hexavalent chromium where conventional stainless steels can be expected to fail. In each group, water quenching after $1850 \mathrm{~F}$ gave the best resistance. Results for waterquenched specimens were nearly the same whether they were held at $1850 \mathrm{~F}$ for 0.5 or $2.25 \mathrm{hr}$. The higher annealing temperature $(1950 \mathrm{~F})$ produced the best results of any of the air quenches studied. This would seem to be the annealing temperature of choice if water quenching is not practical.

"See References at end of text. 


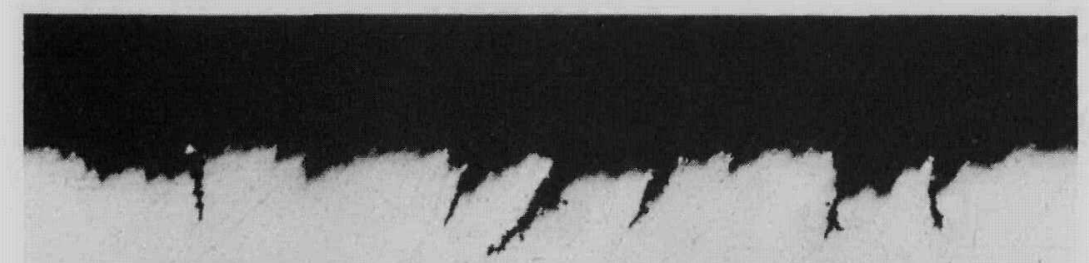

$70 \mathrm{X}$

Exposed in Presence of $\mathrm{Cr}^{+3}$

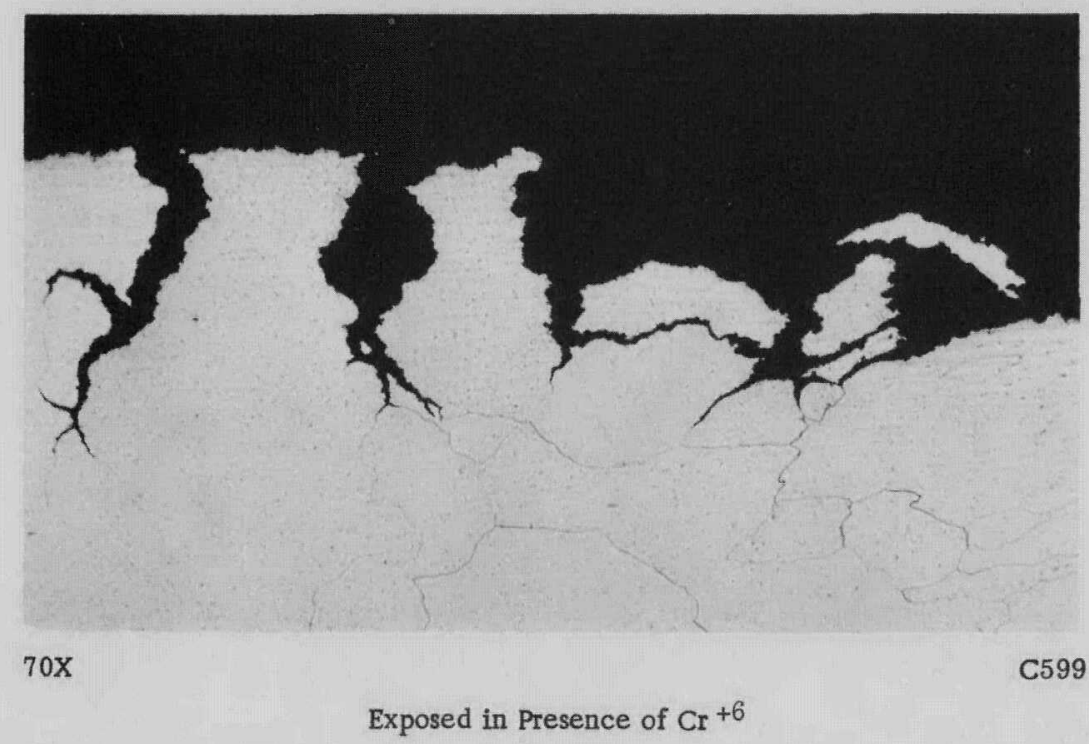

FIGURE B-6. TYPICAL ATTACK ON PARENT METAL AND WELDMENT OF STABILIZED NI-O-NEL FOLLOWING 1000 HR OF EXPOSURE TO BOILING INITIAL THOREX SOLUTIONS WITH $0.20 \mathrm{M} \mathrm{Al}^{+3}$ AND CHROMIUM IN TWO VALENCE STATES

Both specimens were heat treated for $2.0 \mathrm{hr}$ at $1950 \mathrm{~F}$ after welding and air quenched. 
TABLE B-4. CORROSION RATES AND MAXIMUM INTERGRANULAR PENETRATION AFTER 1000 HR OF IMMERSION OF WELDED, STABILIZED NI-O-NEL IN BOILING INITIAL THOREX (0.20 $\mathrm{M} \mathrm{Al}^{+3}$, ADDED) SOLUTIONS(a)

\begin{tabular}{|c|c|c|c|c|c|c|c|c|c|c|}
\hline \multirow[b]{4}{*}{ Heat Treatment $(\mathrm{c})$} & \multicolumn{5}{|c|}{$\operatorname{Set}(A)^{(b)}$} & \multicolumn{5}{|c|}{$\operatorname{Set}(B)^{(b)}$} \\
\hline & \multicolumn{3}{|c|}{$\begin{array}{l}\text { Corrosion Rate, } \\
\text { mils per month }\end{array}$} & \multirow{2}{*}{\multicolumn{2}{|c|}{$\begin{array}{c}\text { Intergranular } \\
\text { Penetration, } \\
\text { mils }\end{array}$}} & \multicolumn{3}{|c|}{$\begin{array}{l}\text { Corrosion Rate, } \\
\text { mils per month }\end{array}$} & \multirow{2}{*}{\multicolumn{2}{|c|}{$\begin{array}{c}\text { Intergranular } \\
\text { Penetration, } \\
\text { mils }\end{array}$}} \\
\hline & \multirow{2}{*}{$\begin{array}{l}\text { Weight } \\
\text { Loss }\end{array}$} & \multicolumn{2}{|c|}{ Metallography } & & & \multirow{2}{*}{$\begin{array}{c}\text { Weight } \\
\text { Loss }\end{array}$} & \multicolumn{2}{|c|}{ Metallography } & & \\
\hline & & Surface & Weld & Surface & $\overline{\text { Weld }}$ & & Surface & Weld & Surface & Weld \\
\hline $1850 \mathrm{~F}, 0.5 \mathrm{hr}$ & 6.6 & 9.2 & 16 & 7 & 14 & 2.1 & 3.7 & 11 & 3 & 10 \\
\hline $1850 \mathrm{~F}, 0.5 \mathrm{hr}$, water quenched & 4.6 & $\ldots$ & -- & -- & - & 1.6 & $\therefore$ & -- & -- & -- \\
\hline $1850 \mathrm{~F}, 2.25 \mathrm{hr}$ & 6.2 & 9.5 & 18. & 7 & 20 & 2.0 & 3.4 & 6.9 & 3 & 10 \\
\hline $1850 \mathrm{~F}, 2.25 \mathrm{hr}$, water quenched & 4.4 & $\ldots$ & - & -- & - & 1.5 & 2.6 & 0.44 & 3 & 3 \\
\hline $1850 \mathrm{~F}, 10.0 \mathrm{hr}$ & 6.0 & 10 & 15 & 8 & 20 & 1.8 & 3.9 & 3.7 & 4 & 5 \\
\hline $1950 \mathrm{~F}, 2.0 \mathrm{hr}$ & 5.7 & 9.7 & 13 & 10 & 18 & 1.8 & 3.9 & 5.0 & 5 & 4 \\
\hline
\end{tabular}

(a) Initial Thorex composition: $13.0 \mathrm{M} \mathrm{HNO}_{3}, 0.050 \mathrm{M} \mathrm{F}^{-}$.

(b) Set (A) specimens were exposed mainly in presence of $\mathrm{Cr}^{+6}$, Set (B) in presence of $\mathrm{Cr}^{+3}$.

(c) All heat treatments were after welding with filler strip. All specimens were air quenched except where noted. 


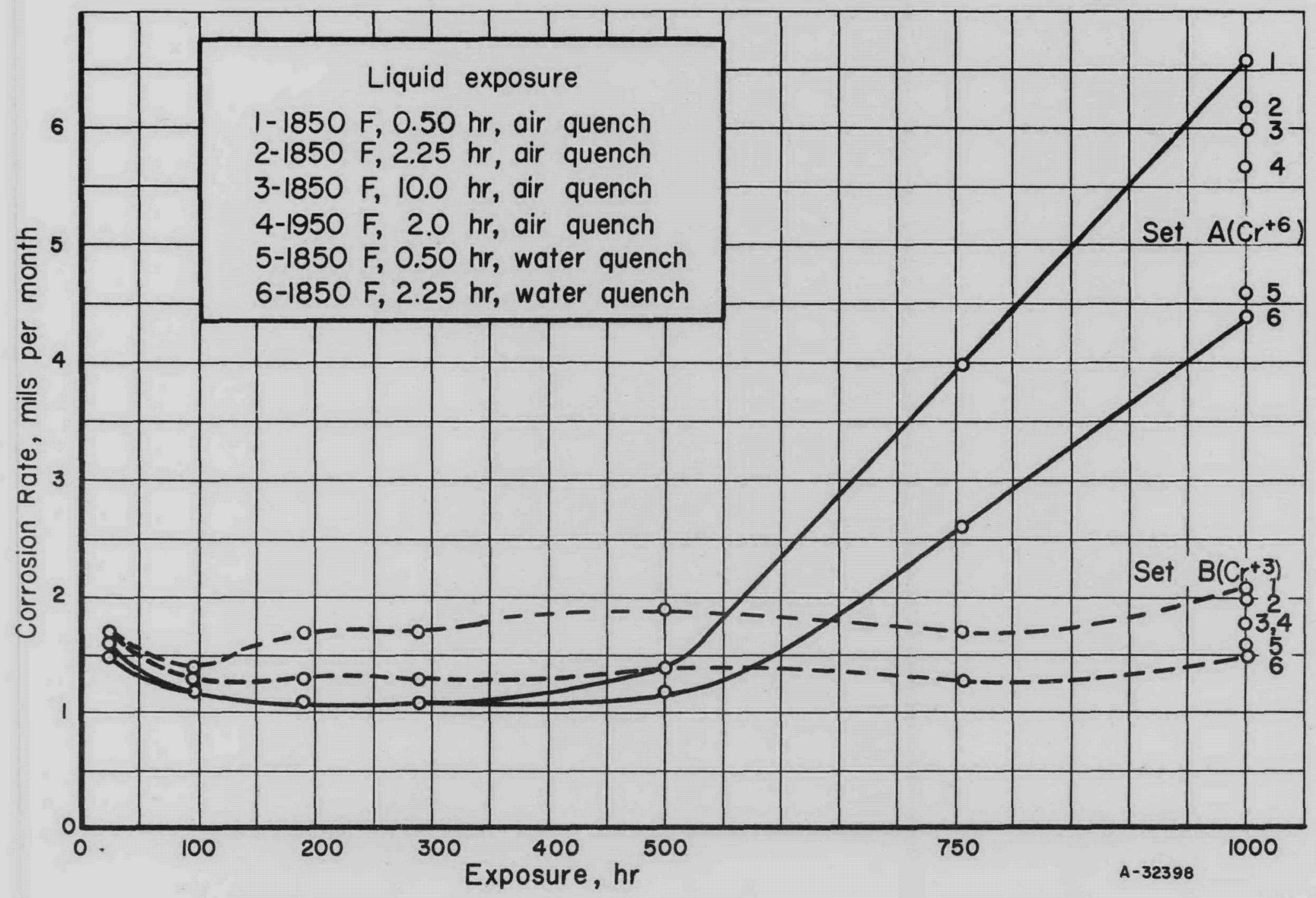

FIGURE B-7. CORROSION OF WELDED STABILIZED NI-O-NEL IN BOILING INITIAL THOREX SOLUTIONS PLUS $0.20 \mathrm{MAl}\left(\mathrm{NO}_{3}\right)_{3}$ 


\section{APPENDIX C}

OBSERVATIONS CONCERNING SULFEXTHOREX DISSOLUTIONS 
The dissolution of Consolidated Edison fuel pins was carried out by the schedule shown in Figure 15 of the text. Table C-1 gives the history of each pin dissolution.

Considerable difficulty was experienced from the pins remaining passivated when placed in the boiling decladding solution. At times the pins could be activated by touching them with an iron nail, or by filing a fresh surface on them. One pin (A-104) could not be made to dissolve and was finally transferred and dissolved by the DarexThorex operation. Several pins, A-105, A-156, and A-177, were declad only after two passes through the Sulfex acid. It is believed that two factors would have caused this passivation: (1) the inhibiting action of the metal ions formed from the corrosive action of the acid on the container during the warmup period, and (2) the inhibiting action of the nitrate ion which may have been present due to inadequate rinsing following the Thorex step. It is true that no difficulties with passivation occurred while decladding the first few pins. It is thought that the walls of the dissolver had not been roughened by the core-dissolution step. Consequently, corrosion of the walls by the cladding acid proceeded at a slower rate and the decladding of the pin started before sufficient metal ions were present to restrict the activation. Beginning with Dissolution NL-12, steps were taken to eliminate both the inhibition by metal ions and the nitrate carry-over. Best results were obtained when the $6 \mathrm{M} \mathrm{H}_{2} \mathrm{SO}_{4}$ was brought to boiling in a glass vessel and was poured over the pin which was already at temperature in the dissolver. Thus no metal ions were present in the starting acid. The nitrate ion was eliminated by more thorough rinsing following the Thorex step, including a refluxing of the wash water in the dissolver.

At first, the difficulty in separating the decladding solution from the pellets was not recognized. The acid was decanted from undissolved end-caps and thoria pellets. A large quantity of salts precipitated from the Sulfex acid during the cooling attending decantation. Subsequent rinsing with water did not remove the salt layer completely and the dissolution of the pellets in Thorex acid was hampered.

The difficulties were eliminated when the $6 \mathrm{M} \mathrm{H}_{2} \mathrm{SO}_{4}$ was diluted to a nominal $4 \mathrm{M}$ concentration after the dissolution had proceeded for about $30 \mathrm{~min}$ (Pins NL-11 to NL-25). Also a better washing technique was employed.

The final Sulfex acid solutions were filtered best through a heated fritted-glass filter. Neither cold fritted glass nor paper was satisfactory.

The final wash from the core-dissolution step became progressively more brown in color. The coloration seemed to result from a partially water-soluble scale which formed on the walls of the Ni-o-nel container. This discoloration may be due to undissolved thoria or urania. The ORNL analyses should establish this.

Only a few results of the ORNL analyses of the solutions were available at the time of writing this report. These show that the uranium losses during the Sulfex 
TABLE C-1. SUMMARY OF DISSOLUTION DATA FOR CONSOLIDATED EDISON FUEL PINS IN NI-O-NEL DISSOLVER

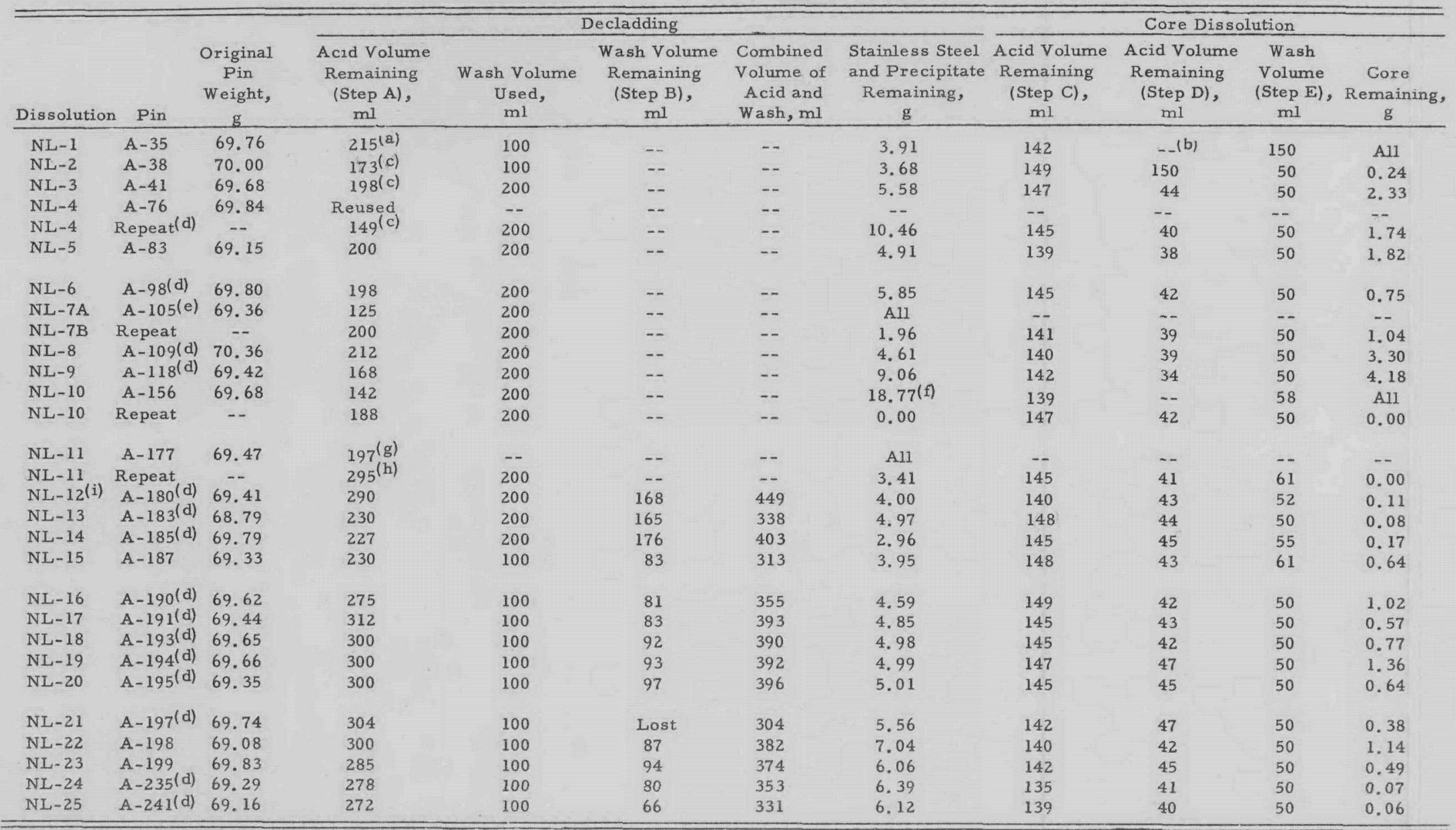

(a) Copious precipitate (appeared to be mainly iron sulfate) from the spent decladding acid was returned to dissolver prior to core dissolution.

(b) Second pass omitted since first pass was effective.

(c) Filtration through paper or unheated fritted glass,

(d) Dissolution started by touching pin with iron nail.

(e) Pin A-104 tried first but dissolution would not start. Pin A-105 would not dissolve until fresh acid was substituted.

(f) Core only partially revealed.

Dissolution would not start until fresh acid was substituted.

(h) From this point on, water added after start of dissolution to make solution nominally $4 \mathrm{M} \mathrm{H}_{2} \mathrm{SO}_{4}$.

(i) From this point on, decladding acid was heated in glass, wash water was also heated. 


$$
\text { C }-3 \text { and } C-4
$$

decladding step varied from 0.1 to $0.9 \mathrm{w} / \mathrm{o}$. The first few pins showed somewhat lower losses. No obvious correlation of these losses with the dissolution condition could be detected. While these losses are significant, it should be pointed out that the thoria pellets in these pins were air fired with most of the uranium present as $\mathrm{U}_{3} \mathrm{O}_{8}$ and a density of only 80 per cent of the theoretical value. ORNL has observed that with pellets fired in hydrogen, most of the uranium is present as $\mathrm{UO}_{2}$, the pellets reach 95 per cent of the theoretical density, and uranium losses during Sulfex decladding are much lower and more acceptable.

The ORNL analyses also indicate that the nitrate carry-over into the Sulfex decladding was, in general, less than $0.01 \mathrm{M}$. This is barely enough to account for passivation of pins with oxide coatings such as may form if the pins were autoclaved. The complete history of the pins prior to their use in these dissolution experiments is not available, at present.

A fairly high carry-over of sulfate ion into the first pass with boiling Thorex solution occurred. This would decrease the core-dissolution rate.

A complete report of the results of these analyses is planned for the near future by L. M. Ferris of ORNL. 
•

.

.

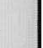

• 


\section{APPENDIX D}

OBSERVATIONS CONCERNING DAREX-THOREX DISSOLUTIONS 


\section{APPENDIX D}

\section{OBSERVATIONS CONCERNING DAREX-THOREX DISSOLUTIONS}

Twenty-five Consolidated Edison fuel pins were dissolved in the Titanium 75A dissolver by the Darex-Thorex process using the schedule shown in Figure 30 of the text. The history of each pin dissolution is given in Table D-1.

The Darex decladding step proceeded with almost violent force when the acid and pin were heated together above 150 to $160 \mathrm{~F}$. The temperature rose abruptly to near the boiling point. The core pellets were freed from their confines about 5 min after the dissolution commenced. The reaction was practically complete after $30 \mathrm{~min}$, but the solution was maintained at boiling for $1 \mathrm{hr}$.

During the first three dissolutions the pins were completely submerged in $400 \mathrm{ml}$ of $2 \mathrm{M} \mathrm{HCl}, 5 \mathrm{M} \mathrm{HNO}_{3}$. The violence of the dissolution spewed acid out the top of the condenser in spite of a large Kjeldahl bulb placed at the top to help overcome this. The volume of the acid was then increased to $500 \mathrm{ml}$ to obtain complete dissolution, and the pin was only partially submerged at the beginning and allowed to drop into the solution as the submerged portion dissolved. This procedure plus more accurate temperature control solved the difficulties of acid loss and the remaining dissolutions presented no problems.

A brown scale formed on the walls of the titanium vessel during the core dissolution. Usually this was removed during the subsequent decladding step. The final wash solution from the core dissolution was fairly clear.

Preliminary analytical results for these solutions as obtained at ORNL indicate uranium losses during the Darex decladding to have varied randomly from 0.2 to 0.4 w/o. Again, as described in the discussion devoted to the Sulfex-Thorex process in Appendix C, these were air-fired low-density pellets, and significantly smaller uranium losses would be expected with high-density pellets. 
TABLE D-1. SUMMARY OF DISSOLUTION DATA FOR CONSOLIDATED EDISON FUEL PINS IN TIT ANIUM 75A DISSOLVER

\begin{tabular}{|c|c|c|c|c|c|c|c|c|c|c|}
\hline \multirow[b]{3}{*}{ Dissolution } & \multirow[b]{3}{*}{ Pin } & \multirow[b]{3}{*}{$\begin{array}{c}\text { Original } \\
\text { Pin Weight, } \\
\mathrm{g}\end{array}$} & \multicolumn{4}{|c|}{ Decladding } & \multirow{2}{*}{\multicolumn{4}{|c|}{ Core Dissolution }} \\
\hline & & & & & Combined & & & & & \\
\hline & & & $\begin{array}{l}\text { Acid Volume } \\
\text { Remaining } \\
\text { (Step A), ml }\end{array}$ & $\begin{array}{l}\text { Wash Volume } \\
\text { Remaining } \\
\text { (Step B), ml }\end{array}$ & $\begin{array}{c}\text { Volume of } \\
\text { Acid and Wash, } \\
\text { ml }\end{array}$ & $\begin{array}{c}\text { Steel } \\
\text { Remaining, } \\
\mathrm{g}\end{array}$ & $\begin{array}{l}\text { Acid Volume } \\
\text { Remaining } \\
\text { (Step C), ml }\end{array}$ & $\begin{array}{l}\text { Acid Volume } \\
\text { Remaining } \\
\text { (Step D), ml }\end{array}$ & $\begin{array}{l}\text { Wash Volume } \\
\text { (Step E), ml }\end{array}$ & $\begin{array}{c}\text { Core } \\
\text { Remaining, } \\
\mathrm{g}\end{array}$ \\
\hline $\mathrm{Ti}-1$ & $A-29$ & 69.51 & 204 (a) & 100 & -- & 7.67 & 148 & 48 & 50 & $0.00^{(c)}$ \\
\hline Ti-2 & $A-31$ & 69.82 & 355 & 100 & -- & 5.09 & 152 & 48 & 50 & 0.44 \\
\hline $\mathrm{Ti}-3$ & $A-37$ & 69.54 & 384 & 100 & -- & 4.97 & 148 & 47 & 50 & None \\
\hline $\mathrm{Ti}-4$ & A -39 & 69.60 & $467^{(b)}$ & 100 & -- & 0.81 & 150 & 45 & 50 & None \\
\hline Ti-5 & $A-45$ & 69.56 & 469 & 100 & -- & 0.75 & 149 & 47 & 50 & None \\
\hline Ti-6 & $A-47$ & 70.62 & 478 & 100 & -- & 0.35 & 149 & 45 & 50 & None \\
\hline $\mathrm{Ti}-7$ & $A-81$ & 69.69 & 475 & 100 & - & 0.35 & 148 & 44 & 50 & None \\
\hline Ti-8 & $A-91$ & 69.40 & 474 & 100 & -- & None & 150 & 46 & 50 & None \\
\hline Ti-9 & A-93 & 69.52 & 478 & 100 & -- & None & 146 & 44 & 50 & None \\
\hline $\mathrm{Ti}-10$ & $A-101$ & 70.08 & 474 & 100 & -- & None & 148 & 45 & 50 & None \\
\hline $\mathrm{Ti}-11$ & $A-104$ & 69.51 & 475 & 100 & - & None & 149 & 46 & 50 & None \\
\hline $\mathrm{Ti}-12$ & $A-107$ & 68.78 & 477 & 100 & -- & None & 150 & 45 & 50 & None \\
\hline $\mathrm{Ti}-13$ & $A-116$ & 69.73 & 475 & 100 & -- & None & 150 & 46 & 50 & None \\
\hline $\mathrm{Ti}-14$ & $A-125$ & 69.47 & 475 & 100 & -- & None & 149 & 46 & 50 & None \\
\hline $\mathrm{Ti}-15$ & A-162 & 69.25 & 479 & 100 & -- & None & 150 & 45 & 50 & None \\
\hline $\mathrm{Ti}-16$ & $A-165$ & 69.52 & 479 & 100 & -- & None & 149 & 45 & 50 & None \\
\hline Ti-17 & $A-169$ & 70.08 & 480 & 100 & -- & None & 148 & 46 & 50 & None \\
\hline $\mathrm{Ti}-18$ & $A-178$ & 68.96 & 475 & 100 & -- & None & 140 & 46 & 50 & None \\
\hline Ti -19 & $A-179$ & 69.92 & 480 & 100 & 578 & None & 151 & 46 & 50 & None \\
\hline $\mathrm{Ti}-20$ & $A-182$ & 69.13 & 480 & 100 & 578 & None & 150 & 46 & 50 & None \\
\hline $\mathrm{Ti}-21$ & A -184 & 69.12 & 481 & 100 & 578 & None & 150 & 44 & 50 & None \\
\hline $\mathrm{Ti}-22$ & A-186 & 70.32 & 480 & 100 & 578 & None & 142 & 46 & 50 & None \\
\hline $\mathrm{Ti}-23$ & $A-188$ & 69.74 & 483 & 100 & 580 & None & 150 & 46 & 50 & None \\
\hline $\mathrm{Ti}-24$ & A-189 & 69.28 & 480 & 100 & 578 & None & 150 & 47 & 50 & None \\
\hline $\mathrm{Ti}-25$ & A -192 & 70.02 & 480 & 100 & 578 & None & 150 & 47 & 50 & $0.18(\mathrm{c})$ \\
\hline
\end{tabular}

a) Acid spewed out of top of condenser.

(b) $400 \mathrm{ml} 2 \mathrm{M} \mathrm{HCl}, 5 \mathrm{M} \mathrm{HNO}_{3}$ used for Dissolutions Ti-1, Ti-2, and Ti-3; $500 \mathrm{ml}$ used for all others.

(c) This is actually the weight of brown scale scraped from dissolver walls. 


\section{APPENDIX E}

COMPOSITIONS OF MATERIALS EVALUATED 


$$
E-1 \text { and } E-2
$$

TABLE E -1. NOMINAL COMPOSITION OF ALLOYS EVALUATED

\begin{tabular}{|c|c|c|c|c|c|c|c|c|c|}
\hline \multirow[b]{2}{*}{ Alloy } & \multicolumn{9}{|c|}{ Nominal Composition, w/o } \\
\hline & $\mathrm{Fe}$ & $\mathrm{Ni}$ & $\mathrm{Cr}$ & Co & Mo & $\mathrm{Cu}$ & W & $\mathrm{Nb}$ & $\mathrm{C}$ \\
\hline Type 304 ELC & Bal & 9 & 19 & -- & - & -. & -- & -- & $0.03 \max$ \\
\hline Type 304 & Bal & 9 & 19 & - & -- & -- & -- & -- & 0.08 \\
\hline Type 309 & Bal & 13 & 23 & -- & -- & -- & -- & -- & 0.20 \\
\hline Type $309 \mathrm{~S} \mathrm{Cb}$ & Bal & 13 & 23 & - & -- & -- & -- & $10 \times C$ & 0.08 \\
\hline Type 316 & Bal & 13 & 17 & -- & 2.5 & -- & -- & -- & 0.08 \\
\hline Type $319 \mathrm{~L}$ & Bal & 13 & 18 & -- & 3 & -- & -- & -- & 0.03 \\
\hline Type $329(a)$ & $\mathrm{Bal}$ & 4 & 28 & -- & 1.5 & -- & -- & -- & 0.10 \\
\hline Type 347 & Bal & 11 & 18 & -- & -- & - & -- & $10 \times C$ & 0.08 \\
\hline Type S -590 & 26 & 20 & 20 & 20 & 4 & -. & 3.8 & 3.8 & 0.45 \\
\hline Type S-816 & 3 & 20 & 19 & 45 & 4 & -- & 4 & 4 & 0.4 \\
\hline Hastelloy B & 5 & 65 & -- & -- & 28 & -- & -- & - & - \\
\hline Hastelloy C & 5 & 55 & 16 & $2.5 \max$ & 16 & - & 3.8 & -- & 0.08 \\
\hline Hastelloy F & 21 & 45 & 22 & 2.5 & 6 & -- & 1 & -- & -- \\
\hline Carpenter $20 \mathrm{Cb}$ & $-\cdot$ & 29 & 20 & - & 2 & 3 & -- & 0.7 & -- \\
\hline $\mathrm{Ni}-\mathrm{o}-\mathrm{nel}^{(\mathrm{b})}$ & 32 & 40 & 21 & - & 3 & 2 & -- & - & 0.03 \\
\hline Inconel 700 & - & 50 & - & 30 & -- & - & -- & -- & -. \\
\hline Incoloy 804 & 25 & 42 & 31 & - & - & 0.5 & -- & -- & 0.07 \\
\hline Illium $\mathrm{R}$ & 3 & Bal & 22 & -- & 6.5 & 4 & - & - & 0.20 \\
\hline Illium 98 & 2.5 & $\mathrm{Bal}$ & 26 & - & 8 & 5 & - & - & 0.03 \\
\hline Haynes 21 & 2 & 3 & 28 & 62 & 5 & -- & -- & -- & 0.30 \\
\hline Haynes 25 & 2 & 10 & 20 & 50 & -. &.- & 15 & -. & 0.15 \\
\hline
\end{tabular}

(a) Nitrogen, $0.08 \mathrm{w} / \mathrm{o}$.

(b) Titanium, $0.8 \mathrm{w} / 0$ as stabilizer. 